\title{
Africa and the North
}

This volume discusses Africa's place in the international system, examining the way in which the Westphalian system, in light of the impact of globalization and transnational networks, continues to play a major role in the structuring of Africa's international relations.

The book provides a solid empirical analysis of key global players in Africa - France, the UK, the US, Japan, Germany, the EU and the UN - and of their policies towards the region. In the context of the 'war against terrorism', African political stability has become a consideration of increasing importance. By analysing the relevance of the states in the North, this book challenges the conventional wisdom in recent international relations thinking. It applies the concept of an 'international policy community' to bridge the gap between the 'domestic' and the 'international', explaining why Africa retains a role in global politics out of any proportion to its economic weight.

Africa and the North will interest students and scholars of international relations and African politics.

Ulf Engel is Associate Professor of African Politics at the Institute of African Studies, University of Leipzig. Gorm Rye Olsen is Head of the Department of European Studies at the Danish Institute for International Studies in Copenhagen. 


\section{The New International Relations}

Edited by Barry Buzan

London School of Economics

and

Richard Little

University of Bristol

The field of international relations has changed dramatically in recent years. This new series will cover the major issues that have emerged and reflect the latest academic thinking in this particular dynamic area.

International Law, Rights and Politics

Development in Eastern Europe and the CIS

Rein Mullerson

The Logic of Internationalism

Coercion and accommodation

Kjell Goldmann

Russia and the Idea of Europe

A study in identity and international relations

Iver B. Neumann

The Future of International Relations

Masters in the making?

Edited by Iver B. Neumann and Ole Wever

Constructing the World Polity

Essays on international institutionalization

John Gerard Ruggie

Realism in International Relations and International Political Economy

The continuing story of a death foretold

Stefano Guzzini

International Relations, Political Theory and the Problem of Order

Beyond international relations theory?

N. J. Rengger

War, Peace and World Orders in European History

Edited by Anja V. Hartmann and Beatrice Heuser 
European Integration and National Identity

The challenge of the Nordic states

Edited by Lene Hansen and Ole Waver

Shadow Globalization, Ethnic Conflicts and New Wars

A political economy of intra-state war

Dietrich Jung

Contemporary Security Analysis and Copenhagen Peace Research

Edited by Stefano Guzzini and Dietrich Jung

Observing International Relations

Niklas Luhmann and world politics

Edited by Mathias Albert and Lena Hilmermeier

Does China Matter? A Reassessment

Essays in memory of Gerald Segal

Edited by Barry Buzan and Rosemary Foot

European Approaches to International Relations Theory

A house with many mansions

Jörg Friedrichs

The Post-Cold War International System

Strategies, institutions and reflexivity

Ewan Harrison

States of Political Discourse

Words, regimes, seditions

Costas M. Constantinou

The Politics of Regional Discourse

Meddling with the Mediterranean

Michelle Pace

The Power of International Theory

Reforging the link to foreign policy-making through scientific enquiry

Fred Chernoff

Africa and the North

Between globalization and marginalization

Edited by Ulf Engel and Gorm Rye Olsen 



\section{Africa and the North Between globalization and marginalization}

Edited by

Ulf Engel and Gorm Rye Olsen

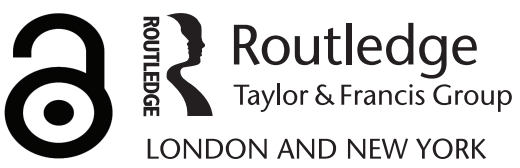


First published 2005 by Routledge

Published 2017 by Routledge

2 Park Square, Milton Park, Abingdon, Oxon OX14 4RN

711 Third Avenue, New York, NY 10017, USA

Routledge is an imprint of the Taylor \& Francis Group, an informa business

Copyright ( 2005 Ulf Engel and Gorm Rye Olsen for selection and editorial matter; individual contributors for their contributions

Typeset in Times by Steven Gardiner Ltd, Cambridge

The Open Access version of this book, available at www.tandfebooks.com, has been made available under a Creative Commons Attribution-Non

Commercial-No Derivatives 4.0 license.

British Library Cataloguing in Publication Data

A catalogue record for this book is available from the British Library

Library of Congress Cataloging in Publication Data

Africa and the north: between globalization and marginalization / edited by Ulf Engel and Gorm Rye Olsen.

p. $\mathrm{cm}$.

Includes bibliographical references and index.

ISBN 0-415-33391-1 (hardback)

1. Africa - Foreign relations - 1960- I. Engel, Ulf.

II. Olsen, Gorm Rye.

DT30.5.A3523 2005

327.60182 '1'09051-dc22 2004018465

ISBN 978-0-415-33391-7 (hbk) 


\section{Contents}

Series editor's preface $\quad$ ix

Notes on contributors $\quad$ xi

1 Global politics and Africa - and Africa in international relations theory

ULF ENGEL AND GORM RYE OLSEN

2 The evolution of Africa's international relations 20

CHRISTOPHER CLAPHAM

3 France and sub-Saharan Africa: A privileged

relationship

JEAN-FRANÇOIS MÉDARD

4 From Realpolitik to the Third Way: British African policy in the new world order

GORDON D. CUMMING

5 United States: The process of decision-making on Africa

DONALD ROTHCHILD AND NIKOLAS EMMANUEL

6 Japan: The tenor and the terrain of foreign policy towards Africa

BOLADE M. EYINLA

7 Germany: Between value-based solidarity and bureaucratic interests 


\section{viii Contents}

8 The European Union: 'European interests', bureaucratic interests and international options

GORM RYE OLSEN

9 The United Nations: A peripheral organization on the periphery of the world

GORM RYE OLSEN

10 Africa and the North: Policy communities and different types of state - theoretical challenges

ULF ENGEL AND GORM RYE OLSEN 


\section{Series editor's preface}

In International Relations (IR) theory, as in many other aspects of modern life, Africa (meaning sub-Saharan Africa) is the exception. It is the place where ideas and theories from the social sciences that seem to give some purchase on the human condition elsewhere either work badly or do not work at all. The most obvious problem for IR theory in Africa arises from the limited success, or in several cases outright failure, of the attempt to transplant a Westphalian system of states in Africa. During its imperial phase, Europe managed to impose its political form more or less successfully on the rest of the world. Sometimes this was done by imposition, as in much of Africa and Asia. Sometimes it was done by rebellion, as in most of the Americas. And occasionally it was done by adaptive copying, most successfully in Japan, but also up to a point in Thailand, China and Ethiopia. In retrospect, the process of colonization and decolonization can be understood as a political makeover in which adoption of the Westphalian form was the price of political independence and acceptance into international society. Given the scale of the enterprise and the diversity of human conditions in which it was carried out, it has been remarkably successful. Most of the successor states left behind by European imperial era have taken root and made the institutions of sovereignty, territoriality and the right of national self-determination their own. In so doing, and with all their variations in (in)efficiency and (in)justice, they have reproduced and expanded the inside/ outside framework of the European political model. This, in turn, allowed IR theories that were essentially rooted in European history to be, with some justification, applied on a global scale.

The widespread failure of this transplant in Africa explains much of the difficulty in applying IR theory there. With the conspicuous exception of South Africa, Africa is largely composed of weak and failed states. As Robert Jackson so rightly pointed out many years ago, the African states have full juridical sovereignty (external recognition within international society), but much less in the way of empirical sovereignty (the ability to exert legitimate and effective government throughout their territory). In much of Africa borders are just lines on a map rather than effective demarcations of authority. Governments may control only part of the national territory (usually 


\section{$\mathrm{x} \quad$ Series editor's preface}

the capital), and be little more than the currently most successful of various warlords and usurpers who seek to capture the juridical assets of the state for their own advantage. Within this weak political structure all sorts of actors with territorial, political, military, economic, and societal standing exist alongside, and often in competition with, the state. Warlords and insurgency movements can, if they succeed in capturing a fungible resource, use the global economy to sustain themselves. Outside actors active in Africa range from criminal mafias and terrorists, through Western NGOs, transnational corporations and private military companies, to regional or international peacekeeping operations and economic missions from the IMF and the World Bank. All have opportunities to carve out space for themselves, whether with or against the local government, within the fragmented and weakly held terrain of African politics. As decolonization recedes into history, it becomes apparent that this condition is quite durable. It seems decreasingly likely that the African state is suddenly going to become successful, and therefore we need to come to terms with the nature of African politics as it actually exists.

That is the task of this book. Much of the literature on Africa focuses on the dilemma of the African state and what to do about it. This book approaches the subject through the foreign policies of the major powers and some of their international institutions. Blending comparative foreign policy analysis and international relations theory, it explores how the major powers deal with Africa: how the Westphalian and post-Westphalian core of international society deals with a non- or pre-Westphalian part of its periphery. The subject is not African international relations, but Africa in international relations, and the key themes are globalization (mainly economic penetration) and marginalization (the waxing and waning of security interest in Africa). One contribution of this book is that it sets out a well-supported perspective on Africa's position in international society. Another is that it challenges IR theorists to take the African condition seriously. How can a whole continent that largely falls outside the strict inside/outside, domestic/international distinctions, be brought into the conceptual debates about how to understand the international system?

Barry Buzan

London School of Economics 


\section{Notes on contributors}

Christopher Clapham retired from Lancaster University in 2002. He is attached to the Centre for African Studies at Cambridge University. $\mathrm{He}$ has written extensively on African politics and international relations, especially on Ethiopia and the Horn of Africa including Africa and the International System (1996). He is editor of The Journal of Modern African Studies.

Gordon D. Cumming After a short career in the Foreign and Commonwealth Office, Dr Gordon Cumming is now a lecturer at Cardiff University and a specialist in British and French foreign and development policies. He has published a wide range of articles in these fields, as well as a monograph entitled Aid to Africa. French and British Policies from the Cold War to the New Millennium (2001).

Nikolas Emmanuel is a $\mathrm{PhD}$ candidate in Political Science at the University of California, Davis. His studies focus on US-African relations and the evolution of the international aid regime.

Ulf Engel is Associate Professor in Politics in Africa at the Institute of African Studies, University of Leipzig. His current interest is Africa's role in international relations and the dynamics beyond the Westphalian state system. He has published extensively on these topics and German foreign and development policy, including Die Afrikapolitik der Bundesrepublik Deutschland 1949-1999 (2000) and The Foreign Policy of Zimbabwe (1994).

Bolade M. Eyinla is a lecturer in the Department of History, University of Ilorin, Nigeria. He specializes in foreign policy analysis, with particular emphasis on African international relations.

Jean-François Médard is emeritus professor at the Institut d'Etudes Politiques de Bordeaux (Université Bordeaux-Montesquieu). His basic interest is in comparative politics and he is particularly interested in 'comparative corruption'. For many years he has worked on African politics, in particular in Cameroon, Ivory Coast, Kenya, and Botswana. He has also worked on the African state and on Franco-African relations. 


\section{xii Notes on contributors}

Gorm Rye Olsen is Head of the Department of European Studies at the Danish Institute for International Studies in Copenhagen. He also teaches Africa and international relations at the University of Copenhagen. He has published extensively on EU-African relations, development aid issues, international relations, and Danish foreign and development policy.

Donald Rothchild is professor of political science at the University of California, Davis. His recent books include Sovereignty as Responsibility: Conflict management in Africa (co-author, 1996); Managing Ethnic Conflict in Africa: Pressures and Incentives for Cooperation (1997); Ending Civil Wars: The Implementation of Peace Agreements (co-editor 2002). His forthcoming book edited with Philip G. Roeder is entitled Sustainable Peace: Democracy and Power-Dividing Institutions after Civil Wars (Cornell). 


\title{
1 Global politics and Africa - and Africa in international relations theory
}

\author{
Ulf Engel and Gorm Rye Olsen
}

Sub-Saharan Africa has been on the margins of the international system for many years, and yet the continent has been deeply and inherently engaged in the global trade system since the beginning of the nineteenth century. This striking duality between marginalization and 'globalization' has had a significant impact on the academic studies on Africa's place in international politics. Only to a very limited extent have such studies been inspired by theoretical thinking or by the theoretical debates that have taken place within the study of international relations (IR). Also, the duality between marginalization and globalization has had far-reaching consequences for how the region has been treated in international relations theory.

The lack of theoretical interest in Africa and its place in global politics has been the core inspiration for this book. First, according to Stuart Croft, it is striking 'that the IR literature on Africa is incredibly sparse. ... Second, much of what does exist on Africa and IR is not, in actuality, about African and international relations. Rather it is about Africa's role in North-South relations, and here the emphasis is on the North. Third, Africa's intellectual exclusion from the IR mainstream debates has meant that little of the literature on African IR has had any explicit theoretical content' (Croft 1997: 609). Going back to the classical realists, it may be illustrative to refer to Hans Morgenthau and his observations on Africa. In his textbook Politics Among Nations, Morgenthau states that Africa did not have a history before the First World War - 'it was a politically empty space' (Morgenthau 1985: 369). A similar conception is espoused by the founding figure of neo-realism, Kenneth Waltz, who in this main work on neo-realism states that 'it would be . . . ridiculous to construct a theory of international politics on Malaysia and Costa Rica.... A general theory of international politics is necessarily based on the great powers' (Waltz 1979: 72-3).

Kenneth Waltz may be right that a general theory of international politics has to be based on the great powers. Nevertheless, it represents an obvious problem that certain parts of the world, such as Africa, are simply left out of the theoretical debates in IR. For an immediate consideration, there are at least two starting points for reflecting on how and where Africa can be brought into the general theoretical debates on international politics. The 


\section{Ulf Engel and Gorm Rye Olsen}

reflections can either start with the African states and with Africa's relations to the outside or, alternatively, they can start with an analysis of the Africa policies of a number of the most important international actors. This book takes the second approach in its empirical analyses. However, it does not mean that theoretical reflections on the African states including their foreign policies are not both relevant and important for realizing the theoretical ambitions of this book. We have made the choice to restrict ourselves to presenting empirical analyses of the Africa policies of the big players and then combining these analyses with the recent debates on the African state and its external relations.

By choosing the second approach, the book bases itself on two fundamental assumptions. The first is that, by means of thorough empirical analyses of the Africa policy of a number of big international players, states and international organizations, it is possible to get an idea of Africa's place in global politics both in the Cold War period and in the post Cold War era of the 1990s, as well as in the current post September 11 world.

The second assumption is that the analyses of the more or less coherent Africa policy of the great international players make it possible to make some theoretical reflections on Africa's place in global politics, including its place in the crucial period following the terrorist attacks on September 11, 2001. Thus empirical studies of the most-important international actors, informed by a methodologically inspired research design reflecting the state of the art in IR theory, are considered as an adequate starting point for reflections on Africa's role in international relations. It is important to stress that such a research design does not prescribe a particular approach for the empirical studies.

Because of the theoretical ambition of the book, we have asked the authors of the individual chapters to address a number of core issues. We have asked them to look at the 'national' interest of the individual players and the corresponding 'interest' of a number of non-state actors in Africa. Also, the authors have been asked to discuss policy continuity and changes in the Africa policies of the external actors, where it has been important to address issues such as decision-making processes and decisions in crises. In relation to decision-making, it is considered important to identify which actors, institutions, individuals, and lobby groups, etc. have taken part in policy formulations and decisions on Africa. It is also considered relevant to seek to identify underlying notions, ideas or common cultures that may have contributed to structure the interpretation of the problems in Africa, and also if such notions have influenced the policy initiatives of the outside actors.

In summary, there is both a theoretical and an empirical aim of this book. The theoretical aim is to contribute to the understanding of Africa in global politics. The empirical aim is to obtain a thorough understanding of the Africa policies of a number of the most important actors determining the international framework for the region's development. As indicated above, it 
is the assumption of this exercise that empirical analysis of the Africa policy of the big international actors allows us to discuss and theorize on Africa in global politics.

The chapter is organized as follows. First, a brief overview is given over how Africa was treated in IR theory in the Cold War period. It is shown that the studies of Africa in global politics were inspired by the theoretical debates in IR to a limited extent only. The consequences for academic studies of Africa in the post Cold War era are discussed in two sections. One section deals with the consequences of the end of bipolarity for Africa and for the studies on Africa in global politics. It concludes that the majority of contributions on Africa continue to be descriptive and in general to be little informed by IR theory debates. The other section addresses the issue of how the international relations of African states and African statehood are currently changing quite significantly. It concludes that these changes question if it is still analytically fruitful to refer to 'African states' and 'African foreign policy'. The answer is 'yes' but with reservations. The last part of the chapter briefly discusses the results of the empirical analyses and, in particular, addresses the question of how the results can be used to promote the integration of Africa into the theoretical debates within IR.

\section{Africa in IR theory 1960-90}

The colonial period - which for most colonies lasted no more than 60 years did not change the peripheral position that Africa had in the international system. However, colonialism strengthened Africa's integration into the global system in economic, political, and ideological/cultural respects. This operated most clearly through the colonial system that connected the African territories to an emerging global economy as sub-suppliers to the European economies.

In spite of high hopes and great expectations, the formal de-colonization process did not fundamentally alter the peripheral position of Africa. The continent remained on the fringes of the international system, in political as well as economic terms. This was obviously related to the fact that, when the African colonies began to achieve their independence, the Cold War was at its height. In the late 1950s and early 1960s the political and military attention of Europe and the US, but also of the Soviet Union and the PR China, was directed towards the confrontation between 'capitalism' and 'communism'. Therefore, the so-called First and Second World were interested only to a very limited extent in Africa and the immense challenges the new Africans leaders faced on the eve of independence. The United Nations and France were probably some of the very few exceptions from the pattern of widespread neglect and general lack of substantial interest in Africa around the time of de-colonization.

The understanding of Africa as being only of minor importance to the overarching bipolar confrontation between the East and the West was clearly 


\section{Ulf Engel and Gorm Rye Olsen}

reflected in the academic literature on the international politics of the Cold War and in IR theory (Croft 1997; Mark 1994; McKay 1963 and 1966; Thiam 1963; Zartman 1966). The undisputed predominance of national security concerns, power politics and mutual deterrence was reflected strongly in the theoretical debates on international relations. The international system was interpreted in terms of the anarchy among sovereign nation states, and a narrow understanding of what constituted 'national interest' prevailed. The distribution of power among states strongly preoccupied with their own national security was a core element in the interpretation that governed the understanding of global politics during the Cold War. The fact that the study of IR was an emerging discipline in the US may explain why the focus of IR in international relations was almost exclusively on the 'big players' and not on 'less important' actors such as the new African states. Most of the classical realists did not even think that there was a need to deal theoretically with Africa and the international position of the continent, as the earlier quotation from Hans Morgenthau's textbook clearly indicates.

However, there was also a small coterie in academia which, starting from realist assumptions, was interested in Africa's responses to the bipolar international system that developed from the late 1940s. This limited group of researchers was mainly preoccupied with the prospects of pan-Africanism and the policies of the non-aligned movement (Legum 1962; Ajala 1973; McGowan 1968). It is worth noting that such studies on the foreign policy of African states during the Cold War actually became the forerunner of the debate on the 'weak states' in the later IR discussions (see Handel 1981).

The end of the Bretton Woods system in 1971-3 and the first oil-price shock in 1973 led to a global decline of US hegemony. As a consequence, a crisis in classical realism followed (Menzel 2001: $141 \mathrm{ff}$ ). Subsequently, two broad strands of neorealist IR theory developed. One was inspired by the works of Kenneth Waltz and his 'structural realism'. The other trend was based on Robert G. Gilpin and his 'economic realism'. In spite of this change in the general debate on IR theory, it hardly affected the discipline's view of Africa as indicated by the earlier quotation from Kenneth Waltz's principal work. International relations and the Africa policies of the big powers largely continued to be viewed from a geo-strategic, i.e. US-Soviet conflict, perspective.

Even when the Cold War turned warm in Africa, it had remarkably limited impact on the general debates within IR. When the Portuguese withdrew from Angola, Mozambique and Guinea Bissau in 1974-5 and socialist-inspired liberation movements came to power, the level of analysis actually changed, even though the units of analysis remained the same. Thus, states or the 'agents' and the understanding of their national interests remained the core units of the system, while the 'structures', i.e. superpower rivalry, interdependence, etc., were ascribed an increasingly important role. This was particularly obvious in the case of Southern Africa, and the Horn of Africa 
after the 1974 coup d'état and the 'national democratic revolution' of 1977-8 in Ethiopia, which led to the deployment of Soviet and Cuban troops on African soil (Bowman 1968; Grundy 1973; Zartman 1970; Rotberg 1985; Butts and Thomas 1986; Johns 1986; also Southall 1982). Basically, not even the establishment of socialist governments in Africa and the deployment of troops from communist states resulted in studies on the motives and the nature of the local forces behind these dramatic events. To a very large extent, the policy changes were seen only through the mirror of the superpower competition for global influence.

As indicated, the rise of neo-realism in the late 1970s did not lead to new or intensified research on Africa's global position, or on the foreign policy of the African countries, for that matter. Nevertheless, the development of neo-realist theory, as promoted by Barry Buzan, did open the way for more thorough theoretical reflections on the character of the African states in international relations, including the possibility that their foreign policy might actually reflect the actions of local forces and genuine domestic interests. Buzan's reflections on the idea of the state, its physical base, the institutional expression of the state as well as its socio-political foundation, etc. definitely provided helpful instruments for analysing the African state. Also, Buzan's version of neo-realism could explain the obvious limitations on the international behaviour and foreign policies of the African states (Buzan 1991). It is hardly a coincidence that one of the very few books addressing the question of Africa in international affairs, Christopher Clapham's Africa and the International System. The Politics of Survival, published in 1996, was inspired by a number of Buzan's ideas (Clapham 1996).

Parallel to the strong presence of realist and neo-realist thinking, a number of critical theories appeared, during the 1970s in particular. In order to understand the continuing economic dependence of the newly independent African states, the so-called dependencia theory, Marxist-inspired theories of anti-imperialism and world system theory or International Political Economy (IPE) approaches were used by Africans and critical academics in the North to explain Africa's peripheral position in global politics (Rodney 1972; Amin 1972; Amin 1976; Mazrui 1977). The analyses carried out within this framework stressed the structural limitations on the poor countries seeking to start their own so-called self-centred or self-reliant economic development. An almost circular explanation maintained that Africa and other developing countries remain in the periphery of the world capitalist system because they are in the periphery of this system. They cannot change their global position because of structural factors in world capitalism.

These radical contributions remained more or less isolated from the general debates between the other IR schools. In the years following the Cold War, it seems as if the radical writers have only to a limited extent continued to produce analyses of Africa and other developing regions. On the other hand, the IPE approach with its systemic view has made some impact on African studies and, to a large extent, it has replaced the older dependencia approach 


\section{Ulf Engel and Gorm Rye Olsen}

(Shaw and Heard 1979; Shaw and Newburry 1979; Nweke 1980; Shaw and Aluko 1984; Shaw 1987). The IPE approach sees the foreign policies of the African states as being strongly influenced by the global political economy, meaning that their external policies tend to follow the political and economic interests of the developed countries. The limited room for manoeuvre is generally explained by an assumed identity between the interests of the elites in the North and the elites in the South. On this type of interpretation, it becomes more or less impossible for the poor countries to develop their own foreign policies or to define 'national interests' that are not externally determined.

While the critical theories enjoyed a fairly dominant position during the 1970s in the debate on Africa's international position, liberal and neo-liberal theories under the rubric of the interdependency approach gained ground. It is quite surprising that the introduction of interdependency approaches in the mid 1970s did not give a boost to studies of Africa's international relations and attempts to theorize about Africa and its place in the international system. First, it is striking because interdependency theories specifically criticised the neo-realists for their all too narrow focus on the great powers and their preoccupation with the international power struggle when theorizing on international relations. Second, it could be expected that the idea of multiple relations tying together countries in a complex system of interdependency, and in particular the argument that states are not the only important actors, would lead to a greater interest in the poor and peripheral areas of the world. However, this did not happen. If the liberal and neoliberal theories had any impact on theorizing on Africa, it has been through their inspiration of theories of development and not in relation to Africa in IR (Dickson 1997).

In summary, the theoretical debates within IR during the 1960s and throughout most of the 1980s included Africa and African approaches in their reflections only to a very limited extent. Though the general theoretical paradigms changed quite significantly in this period, and though the theoretical debates between the different theoretical schools were often quite fierce, there was a striking consensus among scholars working within IR that Africa was of only limited interest for the theoretical debates (Clapham 1987: 575, 582). Given this, it is quite obvious that Africa, its development and its special problems have had strikingly little impact on IR theory. By and large, empirical research on Africa, within either IR or comparative politics, has dealt with specific problems - not general theories.

Thus, an overview of 30 years of the development in IR theory seems to confirm the argument of the chapter. The duality between marginalization and globalization meant that empirical studies of Africa in global politics were inspired by theory only to a limited extent and, most importantly, the region was hardly reflected upon in theoretical debates on IR. This overview also called attention to another interesting observation: the lack of an even weak relationship between theory and empirical changes in Africa. 


\section{The ending of the Cold War: new challenges}

Although the development of IR theory has moved onto new ground with the new debate on post-realism versus social constructivism that unfolded in the 1990s, it seems as if the debate on Africa in international relations has continued its preoccupation with phenomenological aspects. Two broad themes are relevant for the discussion of the interplay between IR theory and empirical developments in the post Cold War era: first, the continued reassessment of Africa's economic and/or strategic role from the point of view of the OECD countries; second, the changing nature of the African state. It is the argument in this section that not only have the empirical developments in the post Cold War period been unique but that fact necessarily has consequences for a theory of IR that takes Africa in global politics into account. Not only has the international system changed dramatically; so too has the African state. Therefore, both themes will be touched upon briefly, which means that the following discussion will involve the recent theoretical debate on the changing nature of the African state.

\section{The changing nature of the international system}

The end of the Cold War made it absolutely clear that the African continent had very limited political and security importance to the OECD states of the North. The disappearance of the bipolar contest for power and influence on the continent meant that Africa more or less lost what was left of its limited importance to global security. Moreover, Africa's share of global trade continued to decline, despite some well-published efforts such as the US tradefor-aid initiative. The shrinking trade figures and the fact that 'Africa's average output per capita in constant prices was lower at the end of the 1990s than it was 30 years before' (World Bank 2000: 8) meant that perceptions of the economic potential of the continent only became less and less optimistic during the 1990s. At the start of the current decade, Africa's share of world trade accounted for less than 2 per cent of it (World Bank 2000: 8). Public images of Africa as the 'lost continent' seemed to prevail and fuelled a debate that questioned the effect of development assistance to Africa in particular (Riddel 1999; van de Walle 1999). Seen in that perspective, it is not surprising that from 1992 onwards the aid flows to sub-Saharan Africa started to decline quite significantly from US $\$ 17.7$ billion in $1990-1$ to US $\$ 13.8$ billion in 2001, measured in fixed prices and exchange rates (OECD 2003: 286-7).

While the volume of development aid declined through the 1990s, the conditions for receiving assistance from the OECD countries increased in number and became tougher for African governments to meet. From the early 1990s, democracy and respect for human rights were introduced as conditions for receiving bilateral development assistance (Crawford 2002; Stokke 1995). The more general quest for good governance represented very wide-ranging interventions in the domestic affairs of the African countries. Among other 


\section{Ulf Engel and Gorm Rye Olsen}

things, the interference manifested itself in the holding of elections in many countries and, in some cases, these elections even led to a change of government.

This lack of appreciable importance to the outside world and not least to the OECD countries clearly changed in the wake of the terrorist attacks on the World Trade Center and the Pentagon on September 11, 2001. It is possible to argue that Africa has gained increased significance in relation to the global war against terrorism since then. Under the impression of a global 'terrorist onslaught' and a global 'war against terrorism', foreign policy interests changed dramatically and the potential role of a number of African states was re-assessed. Islamic militants in African states or what the US and others described as 'militants', the close Bin Laden connections throughout Eastern Africa, numerous money/weapon/drug connections, etc. led to a re-evaluation of Africa in the global security framework. In particular, the Horn of Africa and the areas with a significant Muslim population have come into the focus of the American security concerns. Many OECD governments increased their security cooperation with Africa or supported the newly emerging African security architecture and its regional building blocks. Thus security concerns seemed to have become increasingly important in the Africa policies of a number of OECD countries. The policy framework under which the new security concerns were structured and negotiated was the New Partnership for African Development (NePAD). The G-8 group of the world's leading industrial powers took the chance to demonstrate a 'bright side of globalisation' to their critical electorate, and responded to the introduction of NePAD at the G-8 summit in Kananaskis in 2002. The G-8 introduced its own 'Africa Action Plan', which highlighted cooperation on security issues, for instance on the establishment of an African crisis response force by the year 2009.

The increasing focus on security and security-related issues in Africa brings memories from the days of the Cold War when realist thinkers on IR emphasized that security was the core concern of states in international affairs. In relation to Africa specifically, the US, refers to the potential destabilizing consequences of a number of what is imagined as 'weak' states or 'failed states' and the porous borders that are assumed to give strategic advantages to terrorist groups, including possibilities for money laundering. Such observations make it worthwhile to reflect on whether the dynamics of international relations have returned to what they were like during the Cold War.

Probably, there is one important difference as far as Africa in global politics is concerned if we compare the Cold War situation with the current phase of the international development. After September 11, it is possible to argue that sub-Saharan Africa is more important to global security than it was during the Cold War simply because the main threat to the US now comes from terrorists that hide in weak and failed states all over the world, including sub-Saharan Africa. During the Cold War, the main enemy to the 'free world' was clearly located geographically outside Africa. Compared with the 1990s, 
i.e. the post Cold War years when Africa was more or less insignificant in global security politics, today the region no doubt is much more important in security terms because it is important in the American strategy to fight terrorism globally. In such a perspective, the period from the late 1980s up till September 11, 2001 was an 'exception' from a pattern of international relations where security in general has been the overarching priority. The 1990s were characterized by a state of flux where security as well as morality and ethics or even the so-called CNN effect could be the key factors for specific decisions that were taken in this period.

The factors that became decisive during the 1990s depended on the concrete situation, the specific circumstances and the precise time these factors came into the focus of the decision-makers. For example, it is possible to argue that the American/UN intervention in Somalia in 1992 was strongly influenced by moral concerns, whereas the lack of Western action in the case of the Rwandan genocide 1994 has to be explained by the fact that the Americans had learned the lessons from the Somali failure, which meant that moral arguments did not count as much as national and selfish arguments. An identical reasoning can be used to explain the dramatic reductions in aid transfers to Africa. At the same time, it is important to note that the aid transfers did not disappear entirely. Thus, the reductions can be explained by the lack of national interest in Africa among the OECD countries. On the other hand, the crucial factors influencing global politics, specifically the relationship between Africa and the OECD countries, cannot be reduced to narrow security and economic interests. Moral and ethics but also strong bureaucratic interests play a role, and this may explain not only the continued flow of aid to Africa. Moral concerns for Africa may also explain the constant flow of humanitarian emergency assistance to the forgotten crises of Africa (Olsen, Carstensen and Høyen 2003).

Now, how do these developments relate to current trends in IR theorybuilding in general and to IR theorizing on Africa in particular? As far as Africa is concerned, based on a review of a number of books published between 1984 and 1987 on African issues, Christopher Clapham has concluded 'the pieces [of Africa in international relations], in short, are available: it is the overall picture that is missing' (Clapham 1987: 575). This assessment of the state of the art in the mid 1980s still holds true. It implies that the majority of contributions on Africa in IR continue to be descriptive and research designs in general seem to be little informed by IR theory debates. Problems still trump theory (for overviews see Khadiagala and Lyons 2001; Keller and Rothchild 1996; Harbeson and Rothchild 2000; Wright 1999).

\section{The changing nature of the African state}

Turning to the other component in the discussion, namely the African state, with de-colonization the international system granted statehood 


\section{Ulf Engel and Gorm Rye Olsen}

to Africa. In that sense, the African states and thus the African state system started its development from a totally different position from the European states. In Europe, the Westphalian peace meant the beginning of a process of state formation where the states first conquered and established control over territories, and later developed into nations. In Africa the process was totally different. Colonization began with the conquest of territories and later, with de-colonization, states were established (Clapham 1996). However, the new African states were not like their European counterparts. Whereas the European states were characterized by being positively sovereign, by contrast the African states were negatively sovereign because they lacked the attributes usually associated with positive sovereignty, such as the provision of external and internal security for the populations of a given territory and the deliverance of a minimum of public goods.

This lack of positive sovereignty is basically equivalent to saying that statehood in Africa was and still is an illusion. Nevertheless, it was maintained as long as the Cold War lasted (cf. Clapham 1996; Young 1998). It was international law that guaranteed the existence of the African 'quasi-states' that in fundamental respects lacked the empirical statehood that resembled the Westphalian state. The African quasi-states also lacked another fundamental attribute of empirical statehood, namely a minimum of popular support for and loyalty to the governing elites based in the state (cf. Jackson and Rosberg 1986; Jackson 1990, 1992). Therefore with the renewed crisis of neo-patrimonialism in the late 1980s and the early 1990s, when increasing economic hardships were accompanied by demonstration effects of successful regime transition, Africa's ruling elites faced a critical juncture (Villalón and Huxtable 1998).

With the sudden loss of the structuring and to some extent stabilizing effects of superpower rivalry, the African rulers faced a new and potentially much more challenging situation in the post Cold War period. No doubt, additional insecurities introduced by the 'second wind of change' following the introduction of multi-party systems, and the quest for respect for human rights and good governance in the wake of the fall of the Berlin Wall represented a serious threat to the many neo-patrimonial weak states on the African continent. If African ruling elites did not start to change the way politics was organized, they would increasingly have to face violent struggles over shrinking neo-patrimonial rents. In the end such struggles could lead to the disintegration of states, which actually did happen in a number of instances. So-called 'new wars' erupted in a considerable number of countries. i.e. internal wars or civil wars typically involving several irregular groups and guerrilla fighters became the order of the day (Kaldor 1999; Duffield 2001). By the year 2000, about one-fifth of all Africans lived in countries severely disrupted by conflict. Leaving aside independence wars, nearly 20 African countries had experienced at least one period of civil strife since 1960 (World Bank 2000). 
These new challenges to the central government authorities meant that they faced what Hedley Bull describes as 'competing and overlapping authorities' (Bull 1977/94). Some African regimes have experienced a loss of territorial control as a result of lack of internal legitimacy and thus popular backing (Ayoob 1995; Clapham 1996; Pinkney 2001). Due to the many civil wars and the general weakness of the African regimes, the 1990s witnessed a conspicuous trend to privatize the very essential functions of the state, namely defence and security. A considerable number of African governments hired mercenaries to buttress domestic security. Obviously "hiring of mercenaries amounts to a "considerable erosion or a substantial diminution" of "political sovereignty" (Francis 1999: 332; Reno 1988: 72). The privatization of security more than anything makes it pertinent to describe many African states as 'failed' (Clapham 1996: $6 \mathrm{ff}, 39 \mathrm{ff}$; Lock 1998: $146 \mathrm{ff}$; Chabal and Daloz 1999; Hyden 1999). Peter Lock goes as far as to argue that in situations where there are a number of efficiently policed 'islands of security' within a formally sovereign state, 'there is hardly a role for the state, as autonomous security zones are a result of fragmentation' (Lock 1998: 148).

The weakening or direct disintegration of a number of African states means that the governments in question are often unable to control their borders adequately; because of that, smuggling and other types of illicit transactions have been facilitated (Allen 1999: 8; Harris-White 2002: 27). Judged by the estimated financial volume of illegal economic activities, it is quite evident that in many countries, the formal state authorities do not control the bulk of economic activities, including international economic transactions. Increasingly, the emergence of trans-national networks of illegal trade in diamonds, gold, timber, coltan, arms, or drugs has been observed involving fractions of what is sometimes conceptualized as 'the criminalized state' (Bayart et al. 1999). In a period when Africa becomes more and more marginalized in literally every export sector with the exception of oil, it is striking that the region is far from being disconnected from the international economy of crime as it is indicated by the size of the so-called gross criminal product (GCP) (Bayart et al. 1999: $3 \mathrm{f}, 15 \mathrm{f}, 25,31$ ). Experts estimate that the annual volume of the illegal economic transactions in Africa amounts to US $\$ 1,000$ billion, 40 per cent of which alone is ascribed to the drug sector. The mere size of the GCP surpasses the gross national product of subSaharan several times (Lock 1998: 145).

The close relationship between illegal trade in drugs, small arms and other forms of illegal transactions also has repercussions on trafficking in human beings. Because stricter control with immigration and admission procedures have been implemented during the 1990s in Europe, smuggling individuals and larger groups into European countries have become a lucrative international business that also includes immigrants from countries in subSaharan Africa (Meiner and Münz 1997: 27; UNHCR 2000: 169). In short, during the 1990s, i.e. in the post Cold War period, there seems to have been a conspicuous growth in illegal economic transactions involving African 


\section{Ulf Engel and Gorm Rye Olsen}

countries. First of all, this stresses the significance of the distinction between 'formal' and 'informal' activities in African countries. Second, the widespread crime clearly questions how much control the formal state apparatuses have and, moreover, it questions the value of the formal sovereignty of the African state.

The authority and sovereignty of the African states is not only undermined from within. Kevin Dunn thus emphasizes that the room for manoeuvre of African states is also constrained by the strong role played by the international financial institutions (IFIs), the IMF and the World Bank (Dunn 2001: 51). Because the two Washington institutions play such important roles as suppliers of funding for development, this means that a number of African states lose their sovereign decision-making power over a considerable number of domestic policy fields. However, it is not only the two Washington institutions that exert strong influence over the course of development on the continent; bilateral donor governments also interfere in domestic politics, which leads Kevin Dunn to argue that an increasing 're-colonization' of many African states has taken place in recent years, i.e. after the end of the Cold War (Dunn 2001: $51 \mathrm{ff}$ ). On top of the economic and political conditionalities imposed by the donors, African states are faced with global regimes that structure many policy fields and discourses they hardly participate in. These may be in economics, such as the WTO rounds or EU negotiated post-Lomé Regional Economic Partnership Agreements. They may also be to do with environmental issues such as the debate on genetically manipulated food or access to affordable pharmaceutics, or it may involve intellectual property rights, etc.

The presence of big trans-national companies (TNCs) represents yet another obvious threat to the freedom of action of African host governments. It is a fact that the economic capacity of TNCs is many times larger than that of any African state, including oil states like Nigeria. In some situations, the TNCs simply circumvent the local state and perform state functions, for example by building and expanding infrastructure installations such as roads, railways and harbours or providing their own security. In other instances, TNCs have entered into alliances with regional strongmen and thus undermined the authority of the host government (Reno 1998).

It may be controversial to claim that the actions of non-governmental organizations (NGOs) may have exactly the same consequences as those of the IFIs, the bilateral donors and the TNCs as far as they undermine the authority of the African states. The NGOs quite deliberately circumvent the states in Africa by performing a number of functions in social affairs, in health and in education that are usually considered a public responsibility. Christopher Clapham substantiates the role of Western NGOs by mentioning that they 'created parallel governments with often vastly greater resources at their disposal than the state itself ...' (Clapham 1996: 256).

Against this background a new debate has unfolded, centred on perceptions of 'failed states' and different 'degrees of statehood' (Clapham 1998), where 
many African states are seen as failures. There is no doubt that developments during the last couple of decades have resulted in a general fragmentation of the African states, which means that we are dealing with underinstitutionalized entities that neither control their territory nor manage to provide security for their citizens, not to mention the lack of delivery of even the most basic public goods. In others, the states have been unable to fulfil even minimalist expectations towards statehood. There are also examples where states have exercised their functions only over a limited territory or with regard to some but not all functions.

Based on this, it is pertinent to ask if it is possible to talk about the foreign policy of African states at all. John Clark argues that it is indeed feasible to talk about African states' foreign policy (Clark 2001). However, the determinants of the foreign policy of African states are very different from what determines the foreign policy of the OECD states. It is the main argument of Clark that the foreign policy of African states is mainly about regime security and thus the survival of either the regime or the ruler. The latter argument brings us close to the debate on personal rule in African politics, which has been strong in African studies for a number of years (Jackson 1982; Sandbrook 1986). This kind of African studies tends to equate the policy of the big men with the interests of the states. The national interest, if such a thing is identified, is simply the interest of the ruler. Accepting this point of view makes it difficult to talk about a national interest, and therefore one of the crucial variables of traditional IR theory is not relevant, according to John Clark (2001: $99 \mathrm{ff})$.

For obvious reasons, this situation does not correspond to the widespread assumptions in the West of a more or less universal trend in state-formation and nation-building. Moreover, it also seems clear that states in Africa are not 'like units' as is presupposed in realist thinking. The reason why African states cannot be considered as units of analysis is basically that the foreign policy actions of the African states are determined not by structural circumstances but by very narrow personal concerns. To put it simply: their policies are determined by the survival of the ruler. Moreover, empirical statehood has given way to different degrees of statehood, trans-regional and trans-national dynamics, and a multitude of different forms of governance beyond the states. Of course, it can be maintained that the state in OECD countries and the African states are 'like units' in that both types of state have survival as their ultimate goal, even though in the African case, the 'state' is identical with the ruler.

In summary, there is no doubt that the developments described question the usefulness of having the African state as the basic analytical unit in IR studies if the reference is to the state in the traditional Westphalian system. It is fairly obvious that Africa's external relations consist of a number of elements, and moreover that these elements involve a number of non-state actors pursuing their own more or less 'private foreign policy' (Clapham 1996). If it is accepted that this situation is similar to what Hedley Bull 


\section{Ulf Engel and Gorm Rye Olsen}

describes as 'neo-medieval' (Bull 1983), then it seems logical to argue that Africa represents a pre-Westphalian component in an international system that may contain post-Westphalian components such as the EU. (Maybe some of the OECD states can also be described as belonging to the postWestphalian part of the current international system.)

\section{Africa and the North}

Irrespective of the ongoing globalization processes, the empirical studies in this volume on the Africa policies of a number of important international actors point towards a conclusion that the OECD states continue to be major actors when it comes to Africa. Of course, it is possible to maintain that this particular answer is a result of the way the editors have asked the authors to structure their contributions. Moreover, it has to be admitted that the OECD states chosen for scrutiny in this volume are not selected at random. The cases are all chosen because they are assumed to be of particular importance both to Africa's position in international politics and to Africa's development as far as the external world is important in relation to this project. 'Importance' in this context refers first of all to economic circumstances, specifically trade volumes, aid volumes and the amount of foreign direct investments. Second, importance also refers to historical and not least colonial ties, OECD government initiatives related to security and political development, i.e. cooperation agreements, policy statements, informal and personal contacts that actually lead to policy changes. Finally, importance refers to direct and indirect pressure from the OECD states upon African governments, etc.

Based on this notion of 'importance', the Africa policy of France and Britain are obvious cases to look into. It emerges from Jean-François Médard's analysis of French Africa policy that France has had a very special and close relationship to Africa. Of course, the relationship and the friendly relations have been particularly close with the former colonies. But over the years, France has also developed close collaboration arrangements with nonFrench speaking countries such as Nigeria and South Africa. As it is often stated in Paris, 'France is the only country that has an Africa policy'. Britain is the other prominent former colonial power in Africa, even though after the end of colonial rule, British Africa policy has been much more reluctant than the French policy. Nevertheless, Britain has kept contacts with its former colonies and there is no doubt that London has continued to feel a strong sense of responsibility towards Africa, as was clearly illustrated with the deployment in May 2000 of 1,300 British troops in the midst of the civil war in Sierra Leone.

Also, the volume contains analyses of two non-colonial powers that are supposed to be important for understanding Africa's position in international politics. Germany and Japan are deemed important mainly because of the considerable amounts of development assistance they channel into Africa. 
Also, both countries have considerable volumes of trade with the region. But just as important, the two countries have shown a significant political interest in the region for a number of reasons, such as ethics, but also have broader political ambitions; both Berlin and Tokyo have regarded Africa as instrumental for such goals. Finally, the US is included for a number of obvious reasons. With the disappearance of the Soviet Union, the US is the only superpower left. During the 1990s and even more so after September 11, 2001, Washington has taken a number of important initiatives towards Africa based on its undisputed superiority. The American landing on the beaches of Mogadishu in December 1992 is one case in point, but so is American inactivity during the genocide in Rwanda in 1994. To a very large extent, it was the American reluctance to accept that genocide was taking place in Rwanda that prevented a concerted international response to the atrocities. Finally, more than anything else, the US initiatives following September 11 underline the American influence on Africa's position in global politics. When Washington made the global 'war on terrorism' its primary goal in international politics, almost from day one Africa became an important theatre in this new security framework.

It is not only the actions of the OECD states that contribute to frame Africa's position in global politics. International governmental organizations, such as the World Bank, the IMF, the UN, and not to forget the EU definitely play a role vis-à-vis Africa. This volume therefore contains analyses of the UN and of the EU. Being both a development organization and the organization with the primary responsibility for international peace, the UN can reasonably be expected to be one of the important international actors. The crucial role of the world organization started as early as 1960, when the former Belgian Congo achieved its independence and when the organization deployed a significant number of troops to maintain peace in that enormous central African country. Likewise, from the very start of its existence, the EU had a close and remarkable cooperation with a continuously increasing number of African states. These, for the African countries favourable cooperation agreements, were first codified in the Yaoundé Agreements, then in the Lomé Conventions, and currently in the Cotonou Agreement. Moreover, during the 1990s Africa became an important component in the European common foreign and security policy. As was stated officially several times during the 1990s, to a large extent it was because the EU has a strong interest in and commitment to conflict prevention in Africa.

Based on the empirical studies in the volume, it can be maintained that the OECD states continue showing a behaviour that has obvious similarities with the Westphalian system. At least, it can be argued that the crucial security logic of the traditional international system has been particularly pronounced after September 11, placing the OECD states in an important position when it comes to Africa. This establishment may lead to a not particularly surprising observation that to a very large extent, Africa's position in the 


\section{Ulf Engel and Gorm Rye Olsen}

global system depends on the outside world's, mainly the OECD states', assessment of its importance to the affluent and strong countries. During the Cold War, Africa was considered important to the security of the West on a rather occasional basis, even though, from the late 1970s, the second Cold War placed Africa in a key role on the agenda of both superpowers. In the period between the end of the Cold War and September 11, Africa was generally considered a peripheral and therefore unimportant region of the world. Therefore, moral considerations or bureaucratic self-interest occasionally had some influence on the policies of the OECD states towards Africa, but increasingly Africa was left on its own. But with September 11, that situation changed as has been seen. In summary, this means it is outside forces that determine Africa's international position. On the other hand, Africa's own actions and own doings contribute positively to its position in global politics. It increasingly appears that the neo-medieval nature of Africa's external relations is its main contribution to the theoretical understanding of Africa in global politics.

Thus, another preliminary conclusion to be drawn from this observation is that there is a striking lack of coherence within the international system, or there are significant differences between the OECD states on the one hand and Africa on the other hand when it comes to international behaviour. This lack of coherence could also be phrased by saying there are two different logics within the current international system. In the one, there is a modified Westphalian logic wherein security is still a predominant factor. In the other, there is a pre-Westphalian logic wherein there is no predominant social force or rationale basically due to a combination of domestic factors within the African states and the resulting external actions.

\section{References}

Ajala, A. (1973) Pan-Africanism: Evolution, Progress and Prospects, Thetford: Deutsch. Allen, C. (1999) 'Africa and the Drug Trade', Review of African Political Economy, 26, 5-11.

Amin, S. (1972) 'Underdevelopment and Dependence in Black Africa - Origins and Contemporary Forms', Journal of Modern African Studies, 10 (4), 503-24. (1976) Unequal Development. An Essay on the Social Formations of Peripheral Capitalism, Hassocks: The Harvester Press.

Ayoob, M. (1995) The Third World Security Predicament. State Making, Regional Conflict and the International System, Boulder: Lynne Rienner.

Bayart, J.-F., Ellis, S. and Hibou, B. (1999) The Criminalization of the State in Africa, Bloomington: Indiana University Press.

Bowman, L. W. (1968) 'The Subordinate State System of Southern Africa', International Studies Quarterly, 12 (3), 231-61.

Bull, H. (1977/94) The Anarchical Society. A Study of Order in World Politics, Basingstoke: Macmillan Press.

Butts, K. H. and Thomas, P. R. (1986) The Geopolitics of Southern Africa. South Africa as Regional Superpower, Boulder, CO, London: Westview Press. 
Buzan, B. (1991) People, States and Fear. An Agenda for International Security Studies in the Post-Cold War Era, Hemel Hempstead: Harvester Wheatsheaf.

Chabal, P. and Daloz, P. P. (1999) Africa Works. Disorder as Political Instrument, Bloomington: India University Press.

Clapham, C. (1987) Review article, 'Africa's International Relations', African Affairs, 86 (345), 575-84.

-(1996) Africa in the International System. The Politics of State Survival, Cambridge: Cambridge University Press.

-(1998) 'Degrees of Statehood', Review of International Studies, 24, 143-57.

Clark, J. (2001) 'Realism, Neo-Realism and Africa's International Relations in the Post-Cold War Era', in K. Dunn and T. Shaw (eds), Africa's Challenge to International Relations Theory, Basingstoke: Palgrave, 85-102.

Crawford, G. (2002) Foreign Aid and Political Reform. A Comparative Analysis of Democracy Assistance and Political Conditionality, Basingstoke: Palgrave.

Croft, S. (1997) Review article, 'International Relations and Africa', African Affairs, 96 (385), 607-15.

Delancey, M. W. (ed.) (1979) Aspects of International Relations in Africa, Bloomington, IN: Indiana University Press.

Dickson, A. (1997) Development and International Relations. A Critical Introduction, Cambridge: Polity Press.

Duffield, M. (2001) Global Governance and the New Wars. The Merging of Development and Security, London, New York: Zed Books.

Dunn, K. (2001) 'Madlab \#32: The (Black) African State: Rethinking the Sovereign State in International Relations Theory', in K. Dunn and T. Shaw (eds), Africa's Challenge to International Relations Theory, Basingstoke: Palgrave, 46-63.

Dunn, K. and Shaw, T. (eds) (2001) Africa's Challenge to International Relations Theory, Basingstoke: Palgrave.

Francis, D. J. (1999) 'Mercenary Intervention in Sierra Leone: Providing National Security or International Exploitation?', Third World Quarterly, 20 (2), 319-38.

Grundy, K. W. (1973) Confrontation and Accommodation in Southern Africa. The Limits of Independence, Berkeley, CA, Los Angeles, London: University of California Press.

Handel, M. (1981) Weak States in the International System, London, Totawa, NJ: Frank Cass.

Harbeson, J. W. and Rothchild, D. (eds) (2000) Africa in World Politics. The African State System in Flux, third edn, Boulder, CO: Westview (first edn 1991).

Harris-White, B. (2002) 'Globalization, Insecurities and Responses: An Introductory Essay', in B. Harris-White (ed.), Globalization and Insecurity. Political, Economic and Physical Challenges, Basingstoke, UK: Palgrave.

Hyden, J. (1999) 'Rethinking the Study of African Politics', in D. Olowu, A. Williams and K. Soremekum (eds), Governance and democratisation in West Africa, Oxford: CODESRIA, 9-27.

Jackson, R. H. (1992) 'Juridical Statehood in Sub-Saharan Africa', Journal of International Affairs, 46 (1), 1-16.

Jackson, R. H. and Rosberg, C. (1986) Personal Rule in Black Africa. Prince, Autocrat, Prophet, Tyrant, Berkeley: University of California Press.

Johns, S. (1986) 'Southern Africa: Buffer States Without A Conventional Buffer System', in J. Chay and T. E. Ross (eds), Buffer States in World Politics, Boulder, CO, London: Westview Press, 41-65. 


\section{Ulf Engel and Gorm Rye Olsen}

Kaldor, M. (1999) New and Old Wars: Organized Violence in a Global Era, Stanford, CA: Stanford University Press.

Keller, E. J. and Rothchild, D. (eds) (1996) Africa in the New International Order: Rethinking State Sovereignty and Regional Security, Boulder, CO: Lynne Rienner.

Khadiagala, G. M. and Lyons, T. (eds) (2001) African Foreign Policies. Power and Process, Boulder, CO, London: Lynne Rienner.

Legum, C. (1962) Pan-Africanism, New York: Praeger.

Lock, P. (1998) 'The Withering Military in Sub-Saharan Africa: New Roles for the Private Security Industry?', Afrika Spectrum, 33 (2), 135-55.

Mazrui, A. (1977) Africa's International Relations: The Diplomacy of Dependence and Change, London: Boulder, CO: Heineman; Westview Press.

McGowan, P. (1968) 'Africa and the Non-Alignment: A Comparative Study of Foreign Policy', International Studies Quarterly, 12 (3), 262-95.

McKay, V. (ed.) (1963) Africa in World Politics, New York: Harper and Row.

-(1966) African Diplomacy. Studies in the Determinants of Foreign Policy, London: Pall Mall Press.

Meiner, M. and Münz, R. (1997) 'Migrants, Refugees and Foreign Policy: Prevention and Intervention Strategies', Third World Quarterly, 18 (1), 25-51.

Menzel, U. (2001) Zwischen Idealismus und Realismus. Die Lehre von den Internationalen Beziehungen, Frankfurt am M: Suhrkamp.

Morgenthau, H. J. (1985) Politics Among Nations: The Struggle for Peace and Power, New York: Knopf.

Nweke, G. A. (1980) Harmonization Of African Foreign Policies, 1955-1975: The Political Economy Of African Diplomacy, Boston: Boston University, African Studies Centre.

OECD (2003) Development Co-operation. Efforts and Policies of the Members of the Development Assistance Committee. 2002 Report, Paris: OECD.

Olsen, G. R., Carstensen, N. and Høyen, K. (2003) 'Humanitarian Crises: What Determines the Level of Emergency Assistance? Media Coverage, Donor Interests and the Aid Business', Disasters, The Journal of Disaster Studies, Policy and Management, 27 (2), 109-26.

Pinkney, R. (2001) The International Politics of East Africa, Manchester: Manchester University Press.

Reno, W. (1998) Warlord Politics and African States, Boulder, CO: Lynne Rienner.

Riddel, R. (1999) 'The End of Foreign Aid to Africa? Concerns About Donor Policies', African Affairs, 98, (392), 309-35.

Rodney, W. (1972) How Europe Underdeveloped Africa, Dar es Salaam: Tanzania Publishing House.

Rotberg, R. I. (1985) 'South Africa in its Region - Hegemony and Vulnerability', in R. I. Rotberg and H. S. Bienen (eds), South Africa and its Neighbours. Regional Security and Self-interest, Lexington, MA: D. C. Heath and Co, 1-11.

Sandbrook, R. (1986) The Politics of Africa's Economic Stagnation, Cambridge: Cambridge University Press.

Shaw, T. M. (1987) 'The Future of the Great Powers in Africa: Towards a Political Economy of Intervention', in O. Aluko (ed.), Africa and The Great Powers In The 1980s, London: Lanham, 289-322.

— and Aluko, O. (eds) (1984) The Political Economy of African Foreign Policy. Comparative Analysis, New York: St Martin's Press. 
— and Heard, K. A. (eds) (1979) The Politics of Africa: Dependence and Development, London: Longman.

— and Newburry, M. C. (1979) 'Dependence or Interdependence: Africa in the Global Political Economy', in M. W. Delancey (ed.), Aspects of International Relations in Africa, Bloomington, IN: Indiana University Press, 39-89.

Southall, R. J. (1982) 'Southern Africa: Regional Sub-system or Sub-imperial Complex?', Africa Report, 9 (3), 36-61.

Stokke, O. (ed.) (1995) Aid and Political Conditionality, London: Frank Cass.

Sørensen, G. (2001) Changes in Statehood. The Transformation of International Relations, Basingstoke: Palgrave.

Thiam, D. (1963) La politique étrangere des états africaine, Paris: Presses Universitaires de France.

UNHCR (2000) The State of the World's Refugees 2000, Oxford: Oxford University Press.

Villalón, L. A. and Huxtable, P. A. (eds) (1998) The African State at a Critical Juncture. Between Disintegration and Reconfiguration, Boulder, CO: Lynne Rienner. van de Walle, N. (1999) 'Aid's Crisis of Legitimacy: Current Proposals and Future Prospects', African Affairs, 98, 337-52.

Waltz, K. (1979) Theory of International Politics, New York: Random House. World Bank (2000) Can Africa Claim the 21st Century?, Washington: New York.

Wright, S. (ed.) (1999) African Foreign Policies, Boulder, CO: Westview Press. Young, C. (1998) 'The Colonial State Revisited', Governance, 11 (1), 101-20.

Zartman, I. W. (1970) 'Africa as a Subordinate State System in International Relations', in M. E. Doro and N. M. Stultz (eds), Governing in Black Africa. Perspectives on New States, Englewood Cliffs, NJ: Prentice-Hall, 32441. Hall. 


\title{
2 The evolution of Africa's international relations
}

\author{
Christopher Clapham
}

\section{Introduction}

Africa for the most part came to independence in the late 1950s and early 1960s, within a global order which - paradoxically, given the levels of conflict and insecurity generated by the Cold War in much of the world - was ideally suited to the needs of generally small, weak, poor, and artificially created African states. As a result, these were able to develop and generally put into practice ideologies of international relations that corresponded closely to their needs. This was particularly notable as far as the conception of state sovereignty was concerned. The idea was already outdated in the European states from which it originally derived, but nevertheless the idea of state sovereignty enabled African governments to maximize international support for their continued tenure of power. At the same time, general international respect for their sovereignty absolved them from many of the demands that had underlain the development of the doctrine of sovereignty in Europe. This was the case for territorial defence against potentially threatening neighbours as well as the creation of institutions for effective internal governance.

Over time, developments within the global system combined with economic and political problems within many African states stripped away much of the protection with which they had previously been provided. That situation left them dangerously exposed to a new world that challenged many of the assumptions on which Africa's international relations had previously been based.

This chapter outlines the establishment and erosion of the post-colonial norms of African diplomacy and the responses which African states have devised - by no means always unsuccessfully - to the changed world in which they then found themselves. It then goes on to seek to place Africa within the new 'global politics' in which the (always overrated) status of the state as the primary or even the sole actor in the international system has been severely eroded. Today, Africa has become one of the world's most prominent sites for the interaction between new ideologies, insecurities and sources of economic gain. 


\section{The politics of post-colonialism}

The emergence of African states onto the global stage took place under conditions of remarkable serenity. Save in the former Portuguese colonies and areas of extensive white settlement, Africans were generally spared the traumas of war and revolution that have characteristically accompanied the process of state formation. Nationalist movements promoted overwhelmingly popular demands for independence, to which the incumbent colonial regimes acceded under varying degrees of internal and external pressure. Outside the areas noted and the former Belgian Congo, where public order collapsed within days of independence, the transition to indigenous rule took place peacefully.

De-colonization took place in part because the changed global system of the post-Second World War era had shifted power away from the western European colonizers and towards the two superpowers, the US and USSR. In part, it was also because the benefits of colonialism in Africa were not great enough to induce the colonizers to fight for them once the costs of continued occupation had been increased by African resistance. Finally, it is not to be neglected that because the African successor elites shared the values of the international system as a whole, notably with respect to the maintenance of the existing territorial order, it was easier to accept ending the colonization of the continent, which moreover lead to the inclusion of Africa in the structure of global institutions represented by the United Nations.

The convention by which African states were incorporated into the global system has been aptly characterised by Robert Jackson (1990) as 'quasistatehood'. That is to say, African states were treated 'as if' they were fully sovereign and equal members of the international order, even though many of them did not in practice meet the criteria that would have been required for admission to this order in previous eras. This in turn was possible because the leading states in the world were willing and able to guarantee their membership. The consensual nature of this arrangement is most strikingly illustrated by the fact that in the great majority of cases, the most important guarantor of the territorial integrity and external (and sometimes internal) security of new African states was the very European colonial power from which they had just gained their independence. Even in Ghana, the first British colony in tropical Africa to gain independence, the radical nationalist government of Kwame Nkrumah continued to employ British officers in command positions in the Ghanaian army for several years after independence. In the former French colonies - and the French and British between them accounted for the greater part of colonial Africa - the relations with the colonizer after independence were often very close indeed (Chipman 1989; Golan 1981).

In cases such as former French Guinée, where relations with the colonial power were sharply ruptured at the moment of independence, an African state could look for equivalent (though generally less close) relations with one of the superpowers, both of which were at this period anxious to extend their 


\section{Christopher Clapham}

connections in a continent where neither of them had any extensive previous contacts. In the Horn of Africa, where post-colonial connections were exceptionally weak, levels of internal conflict were high. Proximity to the Middle East provided a source of strategic leverage generally absent elsewhere on the continent; therefore, the superpowers were closely involved from the start. In the case of Ethiopia, it was from soon after the end of the Second World War. The extreme case of global support for African statehood was the former Belgian Congo, where the collapse of order immediately after independence led to the rapid despatch of a force under United Nations authority whose mission was effectively one of state reconstruction.

The consensual nature of Africa's post-independence international relations was both expressed and reinforced by the rapid creation of a reasonably effective set of principles and institutions for regulating the internal diplomacy of the continent. In contrast to other parts of the world, including the Middle East and South Asia where states were engaged in bitter conflicts between one another, states in post-colonial Africa were guided by the principle of solidarity, expressed as Ali Mazrui (1967) put it by 'the concept of "We are all Africans" . This did not exclude areas of disagreement: the more radically anti-colonial African states such as Ghana and Guinée were thoroughly suspicious of what they regarded as the neo-colonial policies of most of their neighbours. On the other hand, the more conservative regimes were on their guard against externally inspired attempts to destabilize their own domestic politics and they were against aspirations to 'African unity' that threatened their independence.

Before very long, however, it became clear that there was room for a compromise, the terms of which were worked out under the aegis of emperor Haile-Selassie's Ethiopia at the meeting of African heads of state in Addis Ababa in May 1963, and led to the formation of the Organisation of African Unity (OAU). As the emperor's prominence suggested, this was a thoroughly conservative arrangement. It rested on the twin precepts of respect for the existing territoriality of African states and non-intervention in their internal affairs, mitigated only by a commitment to the liberation of territories still under colonialism or white minority rule that excluded these territories from the principle of non-intervention.

The OAU principles were far from meaningless. They redefined African 'unity' as a shared commitment to state security at the expense of schemes for continental or regional union. In the process, they denied the legitimacy of any attempt to change or rectify the existing territorialization of the continent, whether through the reunion of peoples divided by the colonial partition, as in the case of the Somalis, or by permitting territories currently within a state to seek separate independence, as in the case of Eritrea. Both cases do much to explain Ethiopia's role in the OAU. They equally removed any reference from legitimate continental discourse to the means by which African states (again other than colonial or white-minority regimes) were governed. On the grounds that this would constitute intervention in their 
internal affairs, this helped to protect regimes that were becoming steadily more dictatorial. The same principles of unrestricted state sovereignty could be used to protect African regimes against intervention by more powerful states from outside the continent (Clapham 1999). The overall result was that African states in their early years received a high level of international protection, both continentally and globally, for which they had every reason to be grateful.

The efficacy of these arrangements was most strikingly illustrated by the Nigerian civil war which broke out in mid 1967, four years after the OAU was founded. Despite barely concealed support by France for the Biafran secessionists and explicit recognition of Biafra by four African states (Côte d'Ivoire and Gabon on the one hand, Tanzania and Zambia on the other), the overwhelming continental consensus was that this was an 'internal affair' of Nigeria. Therefore, the Biafrans were denied equal access to international support in the form notably of armaments, in turn enormously strengthened the diplomatic and military position of the federal government (Stremlau 1977). Elsewhere, the same principles helped to protect African states and regimes from challenges that became much more evident after the OAU consensus started to break down.

\section{The decay of the post-colonial order}

Though the post-colonial order was extremely effective in easing the entry of African states into the international system, it always rested on fragile foundations and could not be maintained indefinitely. The most basic of its underlying contradictions was the insulation that it sought to impose between domestic and international politics. These two arenas can never be effectively separated in the way that the sovereignty doctrine of African and other Third World states sought to do - least of all in poor and weak states with extremely porous frontiers. As African regimes became increasingly dependent on their external patrons for control over their own territories and populations, their domestic politics became a matter of inevitable international concern - which likewise undermined the principles the OAU sought to maintain in the relations between African states.

The critical break came with a series of developments in the second half of the 1970s. Some were closely linked with one another, while others were quite coincidental. First, both chronologically and in order of importance was the Angolan civil war, which followed the Portuguese withdrawal in 1975. Here, because of the nationalist movement's need for outside arms and diplomatic support, the external dependence necessarily involved in liberation war was carried over into the politics of the independent state. Because the nationalist movement was itself divided and its constituent elements - MPLA, FNLA and UNITA - had looked to rival international patrons and regional supporters, foreign powers inevitably became involved in the civil war. African states were equally divided between those that regarded the MPLA as the 


\section{Christopher Clapham}

authentic representative of Angolan nationalism and those that sought some kind of compromise between the three movements. The MPLA's ability to gain an unprecedented level of military support from Cuba and the USSR brought Africa squarely into the calculus of Cold War competition. This was a period when the US withdrawal from Vietnam and the takeover of South Vietnam and Cambodia by the North Vietnamese and Khmers Rouges respectively, had led the USSR to believe that the "world constellation of forces' was favourable to the advance of socialism. That evaluation led to a greatly increased engagement in conflicts throughout the developing world. The subsequent 'Shaba I' and 'Shaba II' invasions of south-east Congo/Zaire by dissidents based in Angola in 1977 and 1978 were repulsed largely as a result of French intervention. However, both incidents intensified the Cold War competition in Africa and marked a breakdown in the principle of nonintervention between African states.

The revolution in Ethiopia from 1975 onwards produced a similar internationalization of domestic conflict on the other side of the continent. The Horn, in any event, had never conformed to the principles that regulated diplomacy in other parts of Africa. It lacked the structure of post-colonial relationships that helped to assure stability elsewhere. The Somali, Eritrean and southern Sudanese conflicts subverted any attempt to separate domestic politics from regional relationships. Moreover, the region's geographical location close to the Middle East and strategically vital sea-lanes provided an incentive for superpower engagement that was generally missing elsewhere. The US role in Ethiopia went back to the Second World War and the corresponding Soviet engagement in Somalia to soon after independence in 1960. The Ethiopian revolution nonetheless precipitated the reversal of what had previously been a fairly stable pattern of alliances. The fall of the emperor in Ethiopia lead to the emergence of a Marxist military regime that sought close association with the USSR and a Somali invasion of south-east Ethiopia that was defeated with Soviet and Cuban assistance. The Sudanese peace agreement of 1972 likewise broke down in the late 1970s, while the Eritrean insurgency escalated out of control.

A further crumbling of the post-colonial consensus resulted from the emergence in some African states of regimes so brutal or grotesquely personalized as to challenge the principle that domestic political arrangements lay beyond the legitimate concern of outside actors. This was, to be sure, a highly selective process: Cold War concerns ensured continuing Western support for the Mobutu regime in Congo/Zaire and Soviet support to the Mengistu one in Ethiopia, regardless of their levels of corruption or brutality. However, not all regimes enjoyed the same protection. Those of Idi Amin in Uganda, Jean-Bedel Bokassa in the Central African Republic (and briefly Empire) and Macías Nguema in Equatorial Guinea became so embarrassing both to other African states and to their outside patrons as to prompt their overthrow. Idi Amin was ousted by a straightforward invasion from Tanzania because he had foolishly prompted it by attempting to annex 
a small area of Tanzanian territory; Bokassa was removed by a French-led putsch and Nguema by an internal coup, all in 1979.

The enhanced military dependence of some African states resulting from the crumbling of domestic political order was accompanied by a much more general intensification of their economic dependence that was most immediately prompted by the dramatic oil price increases of the later 1970s. This was in turn exacerbated by long-term shifts in the global economy away from the primary products on which African states overwhelmingly relied and towards manufactures and especially services as the leading sources of wealth. But structural problems of African economic management also contributed to aggravate the situation. The need to consolidate political support through the distribution of patronage, coupled with varying but sometimes gross levels of corruption and mismanagement, led to desperate attempts to extract more and more resources from a shrinking economic base. The inevitable result was rapidly increasing indebtedness accompanied by intensified domestic opposition, as the funds used to buy internal support dried up.

By the end of the 1970s, therefore, the honeymoon period of Africa's international relations was well and truly over. Save for a few oil-rich states, of which Nigeria was incomparably the most important, the pretensions of the African states to operate as autonomous actors on the international scene challenging the structure of the global system in the name of the world's poor had been cruelly exposed. Instead, their diplomacy was by this time overwhelmingly defensive, seeking to protect their domestic economies and state systems and indeed the survival of their own regimes by making what bargains they could with potential external protectors. The terms on which they could do this in turn became progressively less favourable.

One important indicator was the increasing role of the superpowers in African diplomacy from the mid-1970s onwards and a corresponding militarization of Africa's international relations. Though willing to comply with the formal norms of respect for African territorial statehood, the superpowers and especially the USSR did not have the same commitment to the post-colonial order that the former colonial powers could be expected to maintain. They tended to see the world more crudely (and seldom more crudely than in Angola) as a battleground between one another and their respective state ideologies, neither of which respected any formal division between domestic political structures and global alliances. Though neither Western liberal democracy nor the Soviet Leninist vanguard party state was actually much in evidence in Africa at this time, the superpowers were correspondingly more willing than the former colonial powers to use covert mechanisms to undermine regimes that associated themselves with their global adversary.

This in turn both promoted and was encouraged by a much greater willingness than previously for opponents of incumbent African regimes to resort to armed conflict. While the Nigerian civil war had ended in early 1970s 


\section{Christopher Clapham}

with the complete military victory of the federal forces and the total collapse of resistance in the former Biafra, the wars of the later 1970s did not come to the same definitive conclusion. In Angola, Congo/Zaire, Ethiopia, Sudan and elsewhere, opposition forces fought on, making full use of highly permeable frontiers and gaining tacit support from neighbouring states and major powers. This especially favoured the USSR because it did not have the alliances with the former colonial powers that constricted the US. Moreover, the USSR was favoured because the supply of armaments was the one area in which it enjoyed an overwhelming comparative advantage over its Western rivals. The literature of this period is filled with works on the Soviet role in Africa and the challenge that this posed to Western interests in the continent (Albright 1980; Gavshon 1981; Coker 1985).

\section{The politics of conditionality}

Increased dependence thus subverted the separation of internal and international politics. It meant that the external patrons, as the price for their support, could interfere directly in the ways African states managed their domestic political space. This 'conditionality', as it came to be known, was most immediately evident in the economic sphere where increasing indebtedness obliged African states to accept stringent conditions for the loans that they now desperately needed. The reasons for Africa's economic decline, which contrasted dramatically with the success of the East Asian economies, were hotly contested. Most African commentators and their supporters ascribed it principally to the peculiarly disadvantageous terms on which Africa had been incorporated into the global economy, from the period of the slave trade onwards. On the other hand, external lenders placed the main emphasis on the post-independence mismanagement of African economies, largely through misconceived and badly implemented state intervention, and argued that market forces would rectify the problem. This was a period when in much of the Western world, 'liberal' economists were successfully challenging the Keynesian consensus of the post 1945 era, and the same basic ideology was applied to Africa. In Africa as elsewhere, lenders held the whip hand over would-be borrowers and were able to impose their analysis of the problem as the price for their support. The role of the World Bank as lender of last resort gave it a particularly powerful position in articulating this analysis.

The result was 'structural adjustment', which was a package of policies imposed by the Bank and other international financial institutions as conditions for their loans. The policy was applied during the 1980s to the vast majority of African states. The main elements in the structural adjustment policy involved the removal of foreign exchange controls so that the exchange value of African currencies was determined by the market. Also, the privatization of state corporations or 'parastatals', the liberalization of domestic pricing policies notably for the purchase of cash crops from peasant 
producers, were all part of the package. Finally, the maintenance of macroeconomic stability including a balanced budget was a core issue.

The economic success of these measures was both mixed and highly contested, as was their implementation. Currency convertibility, for example, was straightforward to implement and easy to monitor, whereas measures such as privatization could only be put into effect over a long period and were subject to all manner of potential abuses. What mattered was that Africa's 'international relations' were no longer primarily concerned with attempts by African states to influence the world around them. On the contrary, Africa's international relations were instead concerned with the efforts to protect their domestic sphere of action against external penetration (van de Walle 2001). The whole tenor of Africa's engagement with the international system moved from the offensive to the defensive.

Analogous conditionalities came to apply to the political sphere, where it was no longer acceptable for African states to maintain domestic political systems of a kind that were very different from those of their external mentors. This pressure was initially applied most explicitly to the clients of the USSR. A small number of African states, Angola and Ethiopia most prominent among them, announced their commitment to Marxist-Leninism. At the same time, it was obvious that they urgently needed Soviet military backing for fighting civil wars. After bitter experience of supporting rulers such as Anwar Sadat in Egypt and Siyad Barre in Somalia, who suddenly reversed their global alignment and expelled their former patron, the USSR insisted that its principal clients - dubbed 'states of socialist orientation' in the Soviet jargon of the time - should establish Soviet-style political systems characterized especially by a Leninist vanguard party. Only thus they felt could they insure their investment in these states against the personal power of their rulers. It enabled the USSR to operate not only at the leadership level, but through 'party-to-party' links between fellow apparatchiks throughout the political system. This aspiration threatened to subvert control by African leaders over their own domestic arena, and in several Soviet-allied states, notably Angola, Ethiopia and Sudan, the USSR was credibly suspected of connivance in plots against the leader. In practice, however, the aspiration was a vain one and the supposed vanguard parties, where they counted for anything at all, were ruthlessly subordinated to their leaders.

The demand for Western-style multi-party democracy was much harder to resist. By the late 1980s, the World Bank had come to recognize that simple laissez-faire economics would not be enough to rescue African states from their impasse. Instead, it became the order for the day that an effective state was essential to maintain order, provide public goods and to enforce an appropriate legal regime. The problem, as the Bank came to see it, was that Africa all too often had the wrong kind of state. In particular, the monopoly of power by unaccountable elites gave these a vested interest in maintaining domestic political economies that were deeply inimical to development and the interests of the mass of the population. 


\section{Christopher Clapham}

The solution was to be found in liberal democracy, which was expected to ensure the election of governments that were responsive to the needs of their voters. The sudden collapse of the Soviet bloc gave an enormous boost to this agenda, enabling Western states to make their own support conditional on African adherence to what were now treated as universal moral values. Until that time, Western governments had paid very little attention to the levels of respect for democracy and human rights displayed by their client regimes. One of the first to leap onto the bandwagon was President François Mitterrand of France, at the La Baule Franco-African summit in June 1990. This in turn greatly increased the leverage that Western states and other aid donors were able to exercise over African regimes.

Nor was there any difficulty in demonstrating a demand for political change on the part of would-be voters themselves. The fall of the Berlin Wall was rapidly followed in much of the African continent by mass demonstrations against incumbent rulers, while the collapse of the apartheid regime in South Africa gave a boost to aspirations for democracy throughout the continent not seen since the heady days of independence 30 years earlier. From the viewpoint of Africa's 'international relations', this meant that the continent's external patrons - by now virtually coterminous with the Western capitalist states and international institutions closely associated with them - could achieve what the USSR had tried and failed to do in the previous decade. The Western states could require African states to develop domestic political systems that removed a monopoly of control over internal-external linkages from the incumbent regime and make it possible for outside actors to develop linkages at multiple levels with their African partners.

Instead of having to deal only with states, they could now go behind the backs of the leadership acting in the name of African peoples. In some cases - with US ambassador Smith Hempstone in Kenya as a particularly striking example - outside powers could explicitly support the domestic opposition. Aid regimes were rapidly revised to require recipients to adhere to basic conditions of multi-party democracy, respect for human rights and a collection of other measures that were grouped together under the heading of 'good governance'. The EU switched within a remarkably short period from the view that the political systems of aid recipients under the Lomé Conventions were entirely a matter of domestic sovereignty to insistence on a catalogue of political conditions for the allocation of aid (Clapham 1996, Chapter 8). Other donors did likewise.

When the state itself came under threat, however, as happened in several parts of Africa during the 1990s, it became clear to the outside world that maintaining a basic structure of order in the continent was more important than the precise way in which that order was maintained. The assumption in the early years of post Cold War euphoria that effective states could best be built on the foundations of liberal democracy and free-market economics worked well enough in some cases, but came to seem thoroughly inadequate in others. The complete collapse of government in Somalia after the fall of 
the Siyad Barre regime early in 1991 and the ignominious withdrawal of the American force sent into the country under the doctrine of 'humanitarian intervention' came to symbolize the problems of 'state collapse' in Africa. Even though the Somali case was in several ways a peculiar and exceptional one, there were enough spectacular failures of governance in other parts of the continent, in Rwanda and Congo/Zaire for example or in Liberia and Sierra Leone, to make the existence of some reasonably competent and acceptable government a matter of greater external importance than the way that government had either come to power or exercised it.

\section{African responses}

African rulers have of necessity become extremely adept at manipulating their external relations so as to maximize their freedom of action and protect their domestic base, even when operating from situations of extreme weakness. Some inevitably succumbed to the new politics of conditionality and the parameters within which Africa's international relations had to be conducted. However, the success with which many of them have continued to maintain their position is striking. Outright defiance was rarely a viable option, at either economic or political levels. A few African states remained immune to demands for structural adjustment through the early 1980s, but by the end of the decade they had been forced to comply as a result of changing aid regimes and the renewed volatility of global oil prices. For a period Tanzania was able to resist structural adjustment because it continued to be able to tap nonconditional aid. The same applied to Nigeria because it was sustained by oil revenues. The dramatic shift in the early 1990s from a continent in which few states had legal oppositions and multi-party elections to one in which the vast majority did so testified to the powerful political combination of external backing and domestic demand. Nigeria was again one of the last to give in and not until 1999 did a military regime of (even by Nigerian standards) quite staggering corruptness give way to the country's first elected government for 15 years. Though military coups d'état were not entirely eradicated, they faced disapproval even from within the continent.

At the other end of the spectrum, some governments made a virtue of necessity and committed themselves with few reservations to the new dispensation. In both Ghana and Uganda, new regimes with an initially leftist attitude appear to have become convinced that their crumbling economies could be revived only by adopting market mechanisms. Rapidly, they became the darlings of the donors. Quite apart from the inherent merits of the structural adjustment policies themselves, which continued to be debated, this favoured position enabled both Ghana and Uganda to benefit from exceptionally high aid inflows.

In the case of Uganda, the Museveni regime was able to use external approval of their economic policies to protect themselves against demands for political change. The Ugandan government continued to maintain a 'no-party 


\section{Christopher Clapham}

state' in which the National Resistance Movement increasingly took over the attributes of a single party. For the first time since independence, however, multi-party elections were held on the African continental mainland in which the opposition party was able to win and peacefully assume power. Benin in francophone West Africa was the first state to achieve such a transition, followed by Zambia in Anglophone central Africa. Several other cases followed through the 1990s, with Nelson Mandela's triumphant election in South Africa in 1994 achieving iconic status.

Insofar as there was a characteristic African response to economic and political conditionalities, however, this took the form of formal compliance with the new order subverted by attempts to claw back as much freedom of action as possible on the part of the incumbent regime (van de Walle 2001). In practice, there were marked limits to the extent to which external states and international institutions could take over the management of domestic African economies and political structures. Most obviously, conditionalities had to be implemented on the ground by the very states they were supposed to discipline. In turn, such a situation could delay or manipulate their impact. Privatization of state-owned enterprises, to take one acute example, was a slow and extremely complex business, offering ample opportunities not only for delay but also for manipulation of the process in ways that enhanced rather than reduced the scope for patronage and corruption. One enterprising head of state, Siaka Stevens in Sierra Leone, even managed to 'privatize' some of the more profitable state assets by selling them to himself (Reno 1995).

Political conditionalities were on the whole less easily evaded than economic ones. It was partly because the domestic constituency in favour of reform was much stronger than in the case of economic liberalization (see for example, Bratton et al. 2001). Also, the evasion of the political conditionalities was partly due to the fact that there was one critical and relatively easily monitored event, namely a 'free and fair' multi-party election on which much of the process turned. Equally, a large number of non-governmental organizations, ranging from Amnesty International and Human Rights Watch at one end of the scale through to local groups at the other, made it their business to monitor and publicize the compliance of African governments with 'internationally recognized' standards of performance. Often these standards corresponded to an idealized conception of how liberal democracy and human rights operated in the West. Key elections were watched over by a flood of 'election observers' drawn from outside states, international institutions and non-governmental organizations. Elections were a striking example of the way the 'international relations' of African states had changed over time. Africa's international relations have shifted from the policies these states adopted towards the outside world to the means by which external actors supervised the operation of domestic politics within these states themselves (Abbink and Hesseling 2000).

Even so, the incumbent regimes were not entirely helpless. The end of the Cold War did not completely remove rivalries between external states over 
their influence in Africa, which could be exploited by an adept African leader. France and the US were at odds over access to resources such as oil and telecoms, and sometimes lent their support to different internal factions (Schraeder 2000). Former colonizers were often more indulgent than other external states towards breaches of democratic decorum within their ex-colonies. A major international crisis, like that in the Great Lakes region in the mid and later 1990s, overlaid concern for domestic governance with more directly urgent security issues.

These issues became all the more acute with the emergence of the 'global war on terror' as the primary concern, especially of US policy in the continent. In East Africa at least, this dates from the al-Qaeda bombings of the US embassies in Nairobi and Dar-es-Salaam in August 1998, predating the events of September 11, 2001 by three years. Terrorist acts carried out by Africans in sub-Saharan Africa have in practice proved extremely limited and derive largely from campaigns against white-minority rule on the one hand and from a small number of revolutionary situations, notably in Ethiopia, on the other (Clapham 2003). This made it all the easier for African leaders to present terrorism as an essentially external threat and to sign up as supporters of the 'Global War on Terrorism', 'GWOT' as it rapidly became known, in the process helping to relieve themselves of pressures over issues of domestic governance. The most striking example was Eritrea, where President Isayas Afewerki took immediate advantage of the 9/11 attacks to imprison dissidents from the highest ranks of the ruling party and completely close down the country's independent press, while offering use of Eritrea's ports and other facilities to the US. Ethiopia and Eritrea, despite their conflict with one another, had governments deeply suspicious of the activities of Islamists within their own societies. Therefore, the GWOT also offered support over issues of domestic security, while for Ethiopia it had the added bonus of recruiting the US for the perennially difficult task of controlling warring factions in Somalia. A US base from which to direct anti-terror operations in the region was instead established in Djibouti, another regional state whose commitment to multi-party democracy was equally open to question.

Continental diplomatic norms were likewise adapted in order to tailor global pressures to the shared interests of African states in maximizing their own freedom of action against external pressures. Straightforward opposition to the new agenda was futile, at the collective as much as at the individual state level. African states had instead to come up with mechanisms that identified them with political and economic liberalization, while seeking to keep the implementation of these ideals as closely as possible in their own hands. They did so in a number of ways that in principle undermined the commitment to unfettered state sovereignty enshrined in the 1963 Charter of the OAU while in practice keeping as much as possible of this commitment intact. One early example was the African Charter of Human and Peoples' Rights, drawn up in response to abuses like those of the Amin and Bokassa regimes in Uganda and the Central African Republic, which was approved by the OAU in 1981 


\section{Christopher Clapham}

and came into effect five years later. While formally proclaiming a continental commitment to such rights, this left states with very wide latitude as to their implementation and contained no effective mechanism for monitoring or enforcement. The OAU became more directly involved in helping to negotiate peace settlements between African regimes and opposition insurgencies in a way that had been unacceptable during the Nigerian civil war. Thus in 1993 the OAU established its 'Mechanism for Conflict Prevention, Management and Resolution'. Tragically, one of the first settlements in which it sought to be involved, the Arusha accords on Rwanda, broke down amidst the genocide of 1994.

The shift in 2002 from the OAU to the African Union (AU) marked a further stage in the formal acceptance by African states of constraints on their own behaviour. The AU's Constitutive Act committed its members to oppose unconstitutional changes of government and it provided for a right of intervention in member states in the case of war crimes, genocide and crimes against humanity. Moreover, it permitted the Union to impose sanctions on any member state that failed to comply with its decisions, all of which was a very far cry indeed from the founding principles of the OAU. The initiative that most clearly signified African acceptance of the new world order was the New Partnership for Africa's Development, commonly known as NEPAD, which was closely associated with President Thabo Mbeki of South Africa. Developed from a number of earlier initiatives, NEPAD differed sharply from schemes such as the 1980 Lagos Plan of Action both in its commitment to democracy and in its insistence that Africa could develop only in close association with the global economy. It thus recognized both the economic and the political elements of the new dispensation. At the same time, under the formula of 'African ownership', it sought to insist that African rather than external institutions would determine how this dispensation was implemented. Since the success of NEPAD depended heavily on its ability to attract aid and investment to Africa, this effectively required broad acceptance by major outside states and international institutions of the means by which it would actually be policed.

Despite the establishment of the cumbersome 'peer review' mechanisms, it soon became clear that the level of conditionality African states were prepared to impose on one another did not remotely approach that imposed by external donors. The issue of Zimbabwe most strikingly indicated that African regimes were not in practice prepared to go far beyond the non-intervention norms of the now-defunct OAU. President Robert Mugabe showed himself ready to resort to any measure required to retain power, culminating in the clearly fraudulent presidential election of 2002. The refusal of African states, led by Mbeki's South Africa, to issue the condemnation that Mugabe's defiance warranted showed that the commitment to almost undiluted state sovereignty remained unshaken and that the tensions implicit in the incorporation of African states into the global system remained unresolved. 


\section{Africa in global politics}

In Africa as elsewhere, the role of the state as the sole or at least the overwhelmingly predominant actor in international relations has increasingly given way to a much more complex reality in which states and other actors interrelate and jostle for influence within a globalized political arena. The insistence on sovereignty norms in the formal politics of Africa's international

relations has indeed always been so intense precisely because the level of effective control over their external (and indeed internal) environment that African states have been able to exercise has been so limited. Ever since their creation as part of the global project of European colonialism, they have been deeply and inherently engaged in the global system to an extent that made the emphasis on 'globalization' from the early 1990s onwards little more than the recognition of an existing reality. Indeed, the political and economic conditionalities just discussed were essentially a form of global politics, enforcing norms established among the dominant states of the international order. In turn, they reflected the changing economic orthodoxies and the increased influence of non-state actors within their own domestic politics.

The decline in African states' capacities to police the frontiers - cultural and economic as much as physical - between themselves and the rest of the world, and especially their inability in many cases to control their own territories, also opened the way to the engagement in African international politics of a multiplicity of other actors drawn from both inside and outside the continent. The most obvious and in many respects the most important of these actors were insurgent movements, which both physically contested the state's control of space and at the same time sought to displace the incumbent state authorities, either by taking over the government as a whole or by splitting off part of its territory. The first such movement to make much of an impact, the Biafran secession of the later 1960s, was as we have seen fairly successfully contained. On the other hand, Biafra showed the way to its successors by building up its own diplomatic network and especially by establishing close connections with a number of Western relief agencies in order to bring in food, and under cover of food, weapons and other essentials, into its beleaguered territory. However, one important group of insurgencies - those directed against colonial and white-settler regimes - enjoyed a legitimate status in the African international order and were explicitly excepted from the OAU's rules on non-intervention in the internal affairs of other states. The OAU established a Liberation Committee to help them, and African states supported their efforts to gain a special status in the United Nations and elsewhere.

The breach thus opened in the principles of sovereignty could not easily be closed, even when these 'liberation movements' achieved their goals and took over as rulers of recognized African states. In Angola, especially where the liberation movement had been divided into three factions with rival outside 


\section{Christopher Clapham}

backers, the external relations established during the struggle against the Portuguese continued into the civil war that erupted at the moment of independence in 1975. The Angolan war remained deeply internationalized right through to its close in 2002. In the Horn of Africa, the principles of nonintervention had in any case never been fully respected. However, the level of external engagement intensified with the Ethiopian famine of 1984, when the two principal insurgent movements fighting against the regime in Addis Ababa, the EPLF in Eritrea and TPLF in neighbouring Tigray, were able to bring food supplied by Western relief agencies through Sudan into the territories that they controlled. Justified under the humanitarian slogan 'a starving child knows no politics', this aid nonetheless had important political effects both in consolidating insurgent control over people and territory and in establishing them as acceptable actors in global politics.

With the transformation of African politics after the end of the Cold War, this acceptability took a new and important form. Previously, insurgents other than liberation movements had formally been regarded as 'rebels'; they were now accepted as legitimate participants in the externally mediated political processes that were designed to bring peace and democracy to Africa. Throughout the continent, from Sudan to Angola and Liberia to Mozambique, mediators sought to bring together governments, insurgents and other political actors in talks intended to establish some kind of peace settlement. Except in South Africa, where as previously in Zimbabwe and Namibia this involved a relatively straightforward transfer of power to representatives of the African majority, it proved a tricky business. Only in Mozambique, where special circumstances created exceptional levels of external leverage over both the government and the Renamo insurgents, did it lead to a relatively lasting peace. In Angola and Rwanda, mismanaged or misconceived attempts to negotiate a settlement led to a return to war in the first case, while in the second case it led to the 1994 genocide - the most horrifying event in the recent history of Africa (Clapham 1998). The actual capacity of the international system to manage and resolve African conflicts turned out to be much more limited than had been assumed in the euphoria of the South African transition and the early post Cold War period.

The international politics of insurgency greatly increased the role of nonstate actors in Africa because they were not subject to the same rules of engagement as states and could therefore operate in arenas from which states were excluded. Thus, Oxfam or Save the Children could deliver food to EPLF-held Eritrea when it would not have been permissible for states or intergovernmental organizations to do so. However, these were only the most prominent examples of a massive expansion in the role of NGOs. In many respects, these 'new missionaries' represented a return to older forms of external engagement in Africa. They were representatives of faith-based civil societies in the Western world: they sought to extend to Africa what they regarded as universal values and in the process established counterparts within Africa itself. These new missionaries brought with them both the moral 
authority of the dominant societies in the global order and also the physical and financial resources that were often greater than those available to governments. Equally, they represented a particular conception of Africa in the imagination of the Western world: as a 'dark continent' in need of rescue by high-minded outsiders. This conception was most starkly visible on Western television screens, where Africa was most likely to be pictured in the form of maimed or starving children on the one hand or wild animals on the other.

The NGO invasion took many forms, including famine relief, human rights monitoring, conflict resolution, election monitoring, health care, and environmental projects. Whatever form it took, it represented to the outside world an idea of Africa as a 'problem' for the global system and as a 'failure', most directly on the part of African states. Africa had the highest proportion of refugees of any continent in the world, with a heavy impact on uncontrolled human migration. It was the continent by far the worst affected by AIDS, synonymous with the global spread of disease. It was deeply associated with war and human rights violations, and with 'rebel movements' like the Revolutionary United Front in Sierra Leone and Lord's Resistance Army in Uganda, that were guilty of horrifying and incomprehensible crimes against humanity. Given the role of wild animals in the Western imagination of Africa and their importance for a tourist trade that had become a major export earner in much of East and South Africa, Africa became a major site for environmental protection. This all gave Africa a very peculiar and uncomfortable role in the construction of global politics, which at the same time legitimized external involvement in the cause of what were generally assumed to be universal moral goals.

Nor should actual missionaries be ignored. Africa in the modern era has provided a focus for the proselytizing efforts of the world's two major religions, Christianity and Islam, often with explicitly political agendas. Islamist groups funded from the Middle East and especially from Saudi Arabia have sought to entrench a 'purer' form of Islam in the continent, in place of earlier forms that had generally reached an easygoing accommodation with indigenous social mores and beliefs. Young men were recruited from Muslim societies in Africa, intensively trained in Saudi Arabia and elsewhere and then returned home. They challenged the incumbent Islamic authorities, often from a base in new mosques founded by their patrons in Saudi Arabia. Where this chimed with local political conflicts, notably in parts of East Africa and in Nigeria, it helped to create an explosive mix, which in the aftermath of events in August 1998 and September 2001, was inevitably associated with globalized political Islam. The disruption and cancellation of the Miss World contest due to be held in Nigeria in 2002 as the result of violent Islamist protests provided a peculiarly bizarre clash of alternative forms of globalization.

But Christianity, too, has become deeply engaged in the global politics of Africa. At one level, 'established' churches, both protestant and catholic, have 


\section{Christopher Clapham}

reinforced linkages between the West and Africa. They are often playing a significant role as aid agencies and in supporting demands for democracy and the protection of human rights in Africa. A pastoral letter by Malawi's catholic bishops, for example, was a key step in that country's transition from the Banda dictatorship to multi-party democracy. At another level, 'pentecostalist' churches associated with the Christian right in the US extended their support rapidly through the continent generally, with much less liberal political agendas. The churches, along with professional associations, human rights groups and other organizations, helped to form the 'civil society' through which Western states and non-state actors sought to construct the social base for democracy and 'good governance' in Africa.

In a globalized world, indeed, it becomes less and less possible or indeed meaningful to determine even who is or who is not 'African'. Historically, the international politics of population movement has affected Africa overwhelmingly through the immigration of white settlers into the continent and the societies and regimes that they established, notably in South Africa and Zimbabwe. In the modern era, the boot is on the other foot as large numbers of Africans seek to emigrate to Western Europe and North America, where those who are successful become resident citizens of the countries concerned. On the one hand, this has led to an often brutal politics of migration, with Western states taking drastic measures to restrict the flow of Africans to their own territories - readily stigmatized as AIDS-carriers, drug-smugglers, potential terrorists, or fraudulent asylum-seekers. On the other hand, diaspora Africans established outside the continent have re-injected themselves back into it as businessmen and women, politicians and activists with a concern for African issues, and supporters of political movements within the continent. The EPLF in Eritrea and the RPF in Rwanda were particularly successful in organizing their constituencies outside their home country in support of the insurgencies and later the victorious regimes that they were running within it.

Africa remains a peculiar part of the global system. Economically almost excluded from the developments that have transformed much of Asia, Africa is significant mostly for the increasing importance of the western littoral, from Nigeria to Angola, as a source of oil and to a much lesser extent of other minerals ranging from diamonds to coltan that have generally promoted conflict much more than development. At the same time, it has become an important site for other features of global politics that are identified as 'threats' or sources of 'insecurity' for the core zones of the system. Poverty, disease, crime, terrorism, racial and religious tension, environmental decay, state collapse, and population movement have become almost synonymous with Africa. This ensures that the continent retains a role out of any proportion to its economic weight, but one very different from that of its own choosing. 


\section{References}

Abbink, J. and Hesseling, G. (eds) (2000) Election Observation and Democratization in Africa, London: Macmillan.

Albright, D. E. (1980) Africa and International Communism, London: Macmillan.

Bratton, M., Lewis, P. M. and Gyimah-Boadi, E. (2001) 'Constituencies for Reform in Ghana', Journal of Modern African Studies, 39 (2), 231-59.

Chipman, J. (1989) French Power in Africa, Oxford: Blackwell.

Clapham, C. (1996) Africa and the International System: The Politics of State Survival, Cambridge: Cambridge University Press.

(1998) 'Rwanda: The Perils of Peacemaking', Journal of Peace Research, 35 (2), 193-210.

(1999) 'Sovereignty and the Third World State', Political Studies, 47 (3), 522-37.

_ (2003) 'Terrorism in Africa: Problems of Definition, History and Development', South African Journal of International Affairs, 10 (2), 13-28.

Coker, C. (1985) NATO, the Warsaw Pact and Africa, Basingstoke: Macmillan.

Gavshon, A. (1981) Crisis in Africa: Battleground of East and West, Harmondsworth: Penguin.

Golan, T. (1981) 'A Certain Mystery. How can France do Everything that it Does in Africa - and Get Away With It?', African Affairs, 80 (318), 3-11.

Jackson, R. H. (1990) Quasi-states: Sovereignty, International Relations and the Third World, Cambridge: Cambridge University Press.

Mazrui, A. A. (1967) Towards a Pax Africana: A Study of Ideology and Ambition, London: Weidenfeld \& Nicolson.

Reno, W. (1995) Corruption and State Politics in Sierra Leone, Cambridge: Cambridge University Press.

Schraeder, P. J. (2000) 'Cold War to Cold Peace: explaining US-French Competition in Francophone Africa,' Political Science Quarterly, 115 (3), 395-419.

Stremlau, J. J. (1977) The International Politics of the Nigerian Civil War, Princeton: Princeton University Press.

van de Walle, N. (2001) African Economies and the Politics of Permanent Crisis 1979-1999, Cambridge: Cambridge University Press. 


\title{
3 France and sub-Saharan Africa A privileged relationship
}

\author{
Jean-François Médard
}

France has had a privileged relationship with African countries that dates back to the early colonial period. It is remarkable how little the relationship has changed since the days of colonialism in the late nineteenth century. Therefore, it is pertinent to emphasize continuity as the hallmark of the French Africa policy from President Charles De Gaulle to President Georges Pompidou (1969-74), President Valéry Giscard d'Estaing (1974-81) and even including President François Mitterrand when the Socialists came to power in 1981. This striking continuity is explained by the existence of a common culture concerning Africa shared by the French political elite in spite of its deep political cleavages between the right and the left that traditionally divide the elite. The common understanding of Africa's significance to France explains the lack of real changes in the Africa policy when power changed hands from the right to the left in 1981. And basically it is the common perception held by the elite that explains the inability of the decision-makers to meet the challenges that the French Africa policy faced after the end of the Cold War.

The existence of the common political culture goes back to the universalism of the French Revolution, which inspired the idea of 'assimilation' and mission civilisatrice (civilizing mission) which was used as a mode of legitimizing French colonialism and later also French neo-colonialism. In addition, rhetorical 'tiersmondialism' (i.e. solidarity with the Third World) has been cleverly used by the presidents from De Gaulle to Mitterrand to cover up the practices of French Africa policy. Anti-Americanism has been instrumentalized to justify this policy, as it was the case with Rwanda in 1994, for example. Anti-Americanism is very convenient because it can unify French public opinion from the extreme right to the extreme left against imperialism and globalization. In a way, anti-Americanism combines the complex of Fashoda and the complex of Asterix.

The common understanding and the shared values within the French elite concerning Africa secured the persistence of very strong political, military, economic and cultural ties over the very long period from the early colonial days till the beginning of the twenty-first century. The result has been a special and uniquely differentiated system of relations, a sort 
of Franco-African state or a 'complex', which recently was labelled Françafrique in a rather polemical way (Verschave 1998, 2000). Nevertheless, the expression can be used to underline the reality and the specificity of this system of relations, which is unique compared to other countries' relations with Africa.

\section{Determinants of French Africa policy}

When it granted independence to its colonies in Africa, France did not mean that it was going to leave Africa (Chafer 2001). Therefore in spite of formal decolonization, Françafrique basically continued because of the elite's common understanding of Africa. The system of Françafrique is based on international clientelism, which can be considered a transposition to the international level of a traditional clientelistic relationship, a relationship of personal dependency based on an exchange between two persons, the patron and the client controlling unequal resources (Médard 1976: 103). Thus, international clientelism refers to a mode of domination, or rather to a hegemony, which is not based on the exercise of direct sovereignty but on unbalanced political and economic exchanges between France, the patron state, and its African client states. The lack of balance derives from the fact that each African state is much more dependent on France than France is dependent on each of them. Even though one should not confuse relations between states with relations between persons, the relations between Africa and France are rooted in and strengthened by strong interpersonal ties between the members of the ruling classes of France and Africa, transcending the political cleavages in both places. Consequently, post-colonialism has taken the form of neo-colonialism in the case of France and Africa. However, a clientelistic relationship supposes that the client is not a puppet, but rather has a variable degree of autonomy and can influence its patron, as was the case with Felix Houphouët-Boigny in Côte d'Ivoire. The logic of clientelism is essential to understanding the particular nature of the ties uniting France and the African states.

The whole system of Françafrique is primarily based on the idea that France has a special mission civilisatrice of France (Médard 1999). France thinks it has a message to bring to the world; hence the emphasis on French culture and French language. France was formerly a great power and if after de-colonization it wanted to retain its international status as a middle power, it had to maintain its presence and influence in Africa (Bach 1986). To this must be added the specific policy of national independence in the context of the Cold War, which included several dimensions. One of them was the importance of entertaining a clientele of pro-French states which would not only broaden the French presence in the international arena, but more concretely would support French positions in the United Nations.

An even more important determinant of the Africa policy was the strategic dimension, premised on the fact that France possessed atomic weapons and 


\section{Jean-François Médard}

more generally that it had an independent national defence industry. This required independent access to strategic minerals such as uranium, for both military and civilian purposes. The access to oil was also extremely important. For the supply of uranium, entertaining good relations with apartheid South Africa was a priority (Bach 1990). Gabon and later Niger were important also for uranium, but Gabon was above all the land of the French petroleum company, Elf-Aquitaine (Smith and Glaser 1997; Caumer 1999). Elf was created by De Gaulle as the main tool of the national oil policy. It was no coincidence that it was assigned three main tasks (Le Floch-Prigent 2001). The first one, the official one, was to secure a safe supply of oil. The second was to be a tool of control with regard to the oil-producing African countries through corruption and covert operations in connection with the French secret services. Third, Elf was assigned the role of financing the Gaullist movement; later was this special financial arrangement extended to include all the main parties and politicians.

\section{Policy-making in Françafrique}

The 1958 constitution of the Fifth Republic established a combination of a presidential and a parliamentary regime. The powers of the president are exorbitant for a parliamentary regime but at the same time, according to the parliamentary rule, he has to choose the prime minister within the parliamentary majority. It follows that, when the presidential and parliamentary majorities coincide, the president is the real head of the executive. But when the two majorities are from opposite coalitions, the two leaders of the executive have to share the power - this is called cohabitation. There have been two periods of cohabitation, one with President Mitterrand and Prime Minister Edouard Balladur (1988-95); (Jacques Chirac then being mayor of Paris), and one with President Chirac and Prime Minister Lionel Jospin (1996-2002).

At the executive level, since the time of De Gaulle African affairs have always been considered by constitutional custom as part of a specific attribution to the president described as his domaine reserve (special policy domain). This meant that when there was no cohabitation, the president was the only one in charge of Africa. In periods of cohabitation, the president was still primarily responsible, but he had to take the prime minister into account. During the periods of cohabitation, the two heads of the executive have managed to cooperate. On the whole, even in periods of cohabitation when a unity of direction was somewhat lacking, the role of the president was still predominant concerning African affairs thanks to the cellule africaine controlling the main covert networks.

This informal and partly covert network was controlled from the French presidency, the Elysée palace forming a kind of informal substructure of Françafrique. And the informal system was even more important than the formal one. At the centre of this web of networks was the closest and longest collaborator of De Gaulle, Jacques Foccart, who played the role of a deus ex 
machina in French African policy during the presidencies of De Gaulle and Pompidou (Péan 1990; Smith and Glaser 1997: 33-63; Médard 2002). He had the reputation of being extremely influential, which to a large extent was based on the trust the presidents granted him. On the other hand, Foccart's exceptionally good knowledge of the African ruling classes as well as the French elite was his core asset and explains his tremendous influence on French Africa policy. He understood the significance of personal contacts. His influence on African leaders was based precisely on his sense of human relations and social exchange that enabled him to become a good friend of these leaders, whom he invited to his home and to whom he rendered services of every kind. In addition to his covert network, he cultivated his own personnel network of friends in Africa and France within the political, administrative, military, and business sectors; he was also the head of a business company operating in the West Indies and Africa, and during the Fourth Republic, the informal head of the military unit of the SDECE, the main French intelligence service.

Not just the president, the government and the cellule africaine were involved in policy-making on Africa. There has also been a number of official administrative units influencing policy, and each bureau has had some kind of de facto autonomy even though, each was dependent on different hierarchical authorities. Until 1997 there was a division between the Ministry of Cooperation and the Ministry of Foreign Affairs. The Ministry of Cooperation was in charge of cooperation and technical assistance. The Ministry of Foreign Affairs was in charge of cooperation with the other African countries. But in reality the Ministry of Cooperation managed only one part of the aid, corresponding to technical assistance. The most important part was controlled by the Treasure within the Ministry of Finances, through the Caisse Française du Développement in charge of economic aid. But most of the other ministries were also dealing with Africa. Among them, the Ministry of National Defence was in charge of the French army, a police force (the gendarmerie) and the intelligence service, DGSE, while the Ministry of Interieur (Home Affairs) was responsible for the DST (Défense et Surveillance du Territoire) and the SCIP (Service de Cooperation Internationale de Police) in charge of police cooperation. If we take now the Ministry of National Defence, there was a competition between the gendarmerie, the French army and the DGSE. The two main secret services, DST and DGSE, were also in competition (Smith and Glaser 1997: 65-75).

Alongside this formal system there were a number of more or less private interest groups and informal networks that were overlapping and interconnected at the same time. The interest groups corresponded roughly to private economic interest groups, public interest groups and more recently to NGOs. Among the public interest groups are, in order of priority, the Elf oil company before it was privatized and the French army (Smith and Glaser 1997). The private economic interest groups traditionally included what was formerly called the colonial lobby, which mainly comprises commercial 


\section{Jean-François Médard}

enterprises dealing in tropical agricultural products and import-export businesses (CFDT, etc.) (ibid.). In the post colonial economy, public works companies like Spie Batignoles and Bouygues were increasingly involved in the construction of roads, dams and airports. More recently, telecommunication companies have become quite active. The privatization of public enterprises in Africa has boosted some companies, which have taken control of public utilities, such as Bouygues in Côte d'Ivoire and Bolloré, which is increasingly monopolizing sea transport, the management of the harbours and the railways in former French colonies in Africa. Among the private interests groups, security companies have to be mentioned. These companies recruit their staff from former soldiers, former members of the secret services and all kinds of mercenaries, often in connection with so-called services d'ordre of parties such as the SAC before it was outlawed and nowadays the DPS of the French rightist Front national. The nature of the links these people have with their former employers and administrations have never been clear. Nevertheless, it is obvious that the so-called privatization of networks does not imply the end of the connections between the public and private sectors. In this context, it is important not to forget the increasing corruption of the public sector, the ties with the secret services and with the Free Masons (Smith and Glaser 1997: 133-52; Ottenheimer and Lecadre 2001), since this kind of connection is considered quite useful when doing business of an economic and political nature with African countries. All these companies constitute interest groups in themselves because of their privileged private and personal connections with both the French and African leadership.

Finally, since Franco--African relations were considered part of the domaine reserve of the president, it has to be emphasized that parliament has never played any important role in African policy. Moreover, there has never been a real public debate in parliament on French policy. The budget of the Ministry of Cooperation was voted on without any serious discussion. This notorious absence of parliamentary involvement reflected in part its diminished position within the Fifth Republic institutions. But it is also due to lack of interest among members of parliament, the parties and public opinion. It is only with the genocide in Rwanda and the following crisis of Françafrique that public attention toward French policy in Africa developed.

In summary, the French decision-making system on Africa is extremely complex and it is correspondingly difficult to find out what are the priorities and the decisive motives in individual cases. It is a crucial point that the motives and priorities including which institution and which individuals that exert most influence in a specific case is quite simply difficult to predict. Having stressed that, it has to be admitted that over time, Foccart and the Presidency have in many cases been the most decisive. Moreover, this complex web of public institutions, private and more or less public interest groups, not to mention the role of la cellule africaine, helps explain both the lack of coherence and consistency of the French policy and also the high degree of continuity in policy. 


\section{Cautious adjustment of the Africa policy}

The fact that the system of Françafrique continued with only minor changes until the mid 1990s means that the end of the Cold War in itself had no immediate effect on the French Africa policy. It was only when the African economic crisis fuelled a political crisis involving democratic transitions in a number of countries that the end of the Cold War had some effect on French Africa policy. It simply took time for the French authorities to understand the implications of the end of bipolarity. The decisive factor of the subsequent changes of policy was the economic crisis in France that started in the early 1980s. In a context of increasing unemployment in France, the cost of economic aid to African countries became materially and psychologically unbearable. In addition, the awareness of the inefficiency of economic aid due to the patrimonialization of African states and of Franco-African relations, i.e. the confusion of the public and private domains (Médard 1997a, 1997b), was also becoming evident. France no longer had the means to support the African economies and thus Franco-African clientelism was becoming unsustainable. Within the coalition of the right under Prime Minister Balladur, two important decisions illustrate the turn of the wind: first, the alignment with World Bank and IMF policies, and second the subsequent devaluation in 1994 of the West African currency tied to the French Franc, the CFA Franc, by 50 per cent. This was the beginning of the end of Françafrique.

The genocide in Rwanda that took place during the presidency of Mitterrand became another push for cautious changes in French Africa policy. When the Rwanda Patriotic Front invaded Rwanda from Uganda, France went to the rescue of Rwanda and furnished important military aid to build up a Rwandese army (Prunier 1997). Like all other external powers, France did not do anything to prevent the genocide but its behaviour before, during and after the genocide was, to say the least, questionable (Verschave 1994). The fact created a real shock in France, where for the first time public opinion became interested in what was going on with French policy in Africa. This was the first manifest failure of French policy in Africa. Others followed soon after, with the fall of President Sese Seko Mobutu in Zaire and the various scandals around Elf, all to do with Franco-African relations

The pressure from domestic economic constraints had led some sectors of the ruling class within the Ministry of Finances to reach the conclusion that this systematic clientelism was no longer bearable by the French economy. Other factors also played a role. The deaths of both Houphouet-Boigny in 1993 and Foccart in 1997, two pillars of Françafrique, were an additional factor. The manifest failure of French policy in Africa and the disintegration of the policy-making system with the multiplication of competing networks and administrations was another. Inside the Gaullist camp itself, a reformist wing with Alain Juppé as Chirac's Prime Minister, was pushing toward some degree of normalization: as a Minister of Foreign Affairs under Prime Minister Balladur, Juppé had resented the competition from the networks of 


\section{Jean-François Médard}

Charles Pasqua, who was then the Minister of Interieur. Thus towards the middle of the 1990s, the time was ripening for reform (Cumming 1996; Marchal 1998; Bourmaud 2000; Renou 2002). This reform, prepared under the preceding government, was implemented under Jospin's government in 1997.

The heart of the reform consisted in the absorption of the Ministry of Cooperation by the Ministry of Foreign Affairs. From a symbolic point of view, it meant the end of the special relations between France and its former colonies. The relations were to become normalized. From a practical point of view, it is the end of the distinction between les pays du champ, which were the concern of the Ministry of Cooperation and locally of the Mission de coopération, and the other countries, which were the concern of the Ministry of Foreign Affairs. International Cooperation is now the task of a new direction of the MAE, the Délégation Générale au Développement et à la Coopération Internationale (DGDCI).

In summary, towards the end of the 1990s, there were clear signs of serious attempts to change the special relationship between France and Africa. This was more from necessity than from a strong desire within the French elite that the right-wing government started the process. However, it is difficult to make out whether the strongest motivating factor were the domestic economic problems with rising unemployment or whether the drive to reform Françafrique was also influenced by the obvious problems and the lack of success of this special relationship.

\section{The main elements of French Africa policy}

As already indicated, the main aim of French policy towards Africa has never been to respond to African challenges. Rather, the policy has been motivated by France's civilizing mission. Also, the vision of changing governments of France, a strong middle-ranking power, have influenced the policy. Finally, there is no doubt that French policy has been determined by narrow French interests. Thus, the aims of the policy have been to respond to the challenges to France raised by the African countries. Among the various challenges presented by African countries, we will briefly examine the issues of security, of development, of state building, and finally of democracy.

\section{The challenge of security}

At the time of independence, France signed agreements on military cooperation, including secret clauses, with a number of African countries. The agreements gave France the opportunity to keep military bases in countries such as Senegal, Côte d'Ivoire, Gabon, the Central African Republic (CAR), and Chad. These bases were intended to be used not only for French military reasons but also in order to guarantee the security of the African countries against external and internal threats. For Senegal and Côte d'Ivoire in particular, they were regarded as a kind of deterrent to military coups. Meanwhile, 
France was involved in supplying military technical assistance aimed at assisting the build-up of African armies (Assistance Militaire Technique, AMT). France was the primary provider of weapons and materiél, and was very much involved in the training of the soldiers, both in France and in Africa.

The pattern of French support for the African armies has been contradictory, at best. The lack of policy coherence in this particular area can to a large extent be explained by reference to the extremely complex decisionmaking system, in which it is impossible to predict which concerns and which components in the system will end up being the most decisive. African armies have been used more against their own populations than against neighbouring countries. In some countries, French military support has even been a key element in securing the position of the incumbent's leaders (McKinnon and Charlton 1996; Shaun 2000). On several occasions, the French army directly intervened in coups, as in Gabon, or helped the local army to fight rebels, as in Cameroon against the UPC at the time of independence. Often, the official reason given has been to protect French residents. But in other cases, as in Congo-Brazzaville and Niger, the French army did not back the president.

The French army under President Giscard d'Estaing twice intervened directly in Zaïre against an invasion by the former gendarmes katangais coming from Angola. It has also been involved at different periods of time in Chad, first against internal threats to President François Tombalbaye and then against the intervention from Libya. During the Biafran war, at the demand of Houphouët-Boigny, France was secretly involved in sending weapons and ammunition to the Biafra camp. The pretext was humanitarian, but the main reason for supporting the Biafra secession was that Nigeria was considered a threat to western Francophone Africa. Cameroon, a direct neighbour of Nigeria, had an unsolved problem of boundaries in the oil area west of Mt Cameroon. In 1994, the Nigerian army occupied Bakassi Island. France backed Cameroon in this conflict, in spite of the fact that Nigeria is for her a much more important economic partner than Cameroon. In the case of Rwanda, military aid and intervention of French troops against the attack of the FPR was justified by the 'Anglo-Saxon' threat.

In spite of its record of frequent interventions, during the 1990s French governments were very careful to avoid direct military involvement in African conflicts. Moreover, the French army withdrew from its bases in the Central African Republic and the number of soldiers stationed in Africa was reduced by 25 per cent to stabilize at around 6,000 by the year 2000 . The number of military technical assistance personnel also diminished from 700 in 1995 to 364 in 1999. The present military doctrine of France is to help African armies to build some kind of international police force that can intervene in other African countries in case of widespread unrest or civil war. This is precisely the aim of the organization named RECAMPS (Bellescize 1999), which receives both economic and military support from France. The organization has conducted military exercises in Senegal, Gabon and Tanzania, with the assistance from France. 


\section{Jean-François Médard}

In summary, during the 1990s the high-profile policy of military intervention and the military support to a number of non-democratic African rulers started to change. The most remarkable step no doubt was that France reduced the number of troops permanently based in Africa. The scaling down of its permanent military presence is a fairly clear sign that Paris is serious in its intention to change its relationships with its former colonies. On the other hand, the active involvement in establishing and expanding RECAMPS indicates that France continues to have a strong interest in stability and crisisprevention in Africa. Just this interest in stability explains the deployment of 3,000 French troops in Cote d'Ivoire in the wake of the civil war that broke out in September 2002.

\section{The challenge of development}

If the notion of development has any meaning within the framework of French Africa policy, the development of the African economy has never been a priority to the French political and bureaucratic leaders. It is striking that there has never been an articulated doctrine or intellectual elaboration of what development means. The French decision-makers in matters relevant to development were not really concerned about development and about the supposed purpose of their action. Basically, the real priorities were to defend French economic and political positions, and that is why aid was for the most part bilateral. Bilateral aid was first used as an instrument of political leverage; later, it increasingly became a means of distributing favours to friendly African leaders and to ensure their positive attitude toward France. Development assistance was also used as a means of encouraging French exports and investment, and it therefore became strongly connected with corruption. Accordingly, French policy had to respond to the demands on the French side from businessmen dealing with Africa, and from politicians and parties in need of financing. At the same time, France has had to address the demands coming from the African side; not least, Paris had to pay attention to the demands from structurally fragile African leaders.

In the absence of a local African bourgeoisie, the state was naturally considered the main actor of development. This fitted with the Keynesian approach that was dominant in France at that time and also with the socialist ideology that was shared, at least verbally, by most African leaders. Development was necessarily state-centred. But in the context of a neo-patrimonial state, state-centred meant ruling-class centred. A considerable amount of economic aid was given to African countries in the name of development, and as long as growth followed, this did not raise any serious problem. Part of the aid was recovered by French business. The only issue that has always been and still is discussed is the amount of French public aid in terms of percentage of the French national income. During the 1980s the percentage increased and reached 0.63 per cent in 1992-3, thereby making it one of the highest in the world (OECD 1995: A 10). 
The systematic policy of import substitution followed by African governments, and partly financed by economic aid, was a strong incentive to French exports of equipment goods. For that reason, Africa began to become a cemetery for white elephants. The example of the Transgabonais train is a case in point. When President Omar Bongo of Gabon decided to build the railway, the World Bank refused to finance it because it would not be profitable; the expected traffic was not large enough. Bongo nevertheless decided to build it 'at all costs'. The Fonds Européen de Développement (FED) agreed to finance it because it was a good market for French and European enterprises. The railway had high symbolic value nationally from the point of view of the unification of Gabon. It also had personal significance for President Bongo, since the destination of the train was Franceville, the home village of the Bongo family. Finally, the whole project turned out to be an excellent channel for corruption.

However, even if the economic aid was not really development-oriented and was in large part mismanaged and stolen by the African ruling class, there was some positive spill-over into the poor economies. Economic growth brought tangible benefits to large sectors of the population. It was manifest in countries like Côte d'Ivoire, where Houphouët-Boigny succeeded in attracting a lot of foreign and French investment. But it remains clear that the aid was not development-oriented and the African countries that have received the largest amount of aid were the closest friends of the French government. The case of Gabon is typical. In spite of the fact that Gabon has one of the largest incomes per inhabitant in Africa, it received very considerable amounts of development assistance because of its strategic importance for France. However, in the 1980s and 1990s, with the encouragement of the central government, the coopération décentralisée, whereby local governments, communes and departements organized development projects in partnership with African local governments, met some success. And even if it is not always very efficient, the strategy has the merit of promoting interest in African problems and at the grass-roots level it encouraged personal relations between the populations of these countries.

The problems for the French aid relationship became manifest during the 1980s when the African economic crisis began. With increasing unemployment it became evident that France no longer had the means to pursue its policy of neo-colonial clientelism. Against this background, the French authorities finally adopted the so-called Balladur (or Abidjan) doctrine, which subordinated French economic aid to the structural adjustment policy of the Bretton Woods institutions. This was the first step towards a position that was interpreted as if France was disengaging from Africa. Then in January 1994 came the devaluation of the CFA Franc, which strengthened that impression. The devaluation was felt as a betrayal by the African population and its elite. It was also criticized by both right and left in France as an alignment to Bretton Woods institutions, to globalization and to the USA. 
In the wake of these highly spectacular initiatives there followed a drastic fall in French bilateral economic aid from US \$7.275 million in 1990-1 to US $\$ 4.198$ million in 2001 , corresponding to a fall from 0.61 per cent of the GNI to 0.32 per cent of the GNI (OECD 2003: 228-9). Trade and investment followed the same path and the number of French technical assistants has also considerably diminished. However, it is important to note that at the same time the share of French multilateral aid not only increased; moreover, the greatest part of this multilateral aid was channelled through the European Union (OECD 2003: 248). Increasingly using the European Union to channel aid to Africa had the advantage of diminishing the burden of aid on France while maintaining the special relationship with Africa. Economically, French businesses were in a better position to take advantage of the European markets. Politically, France played the role of a broker within the European institutions to increase the amount of the aid, and within the Paris Club, France lobbied strongly to reduce African debts. Instead of using direct bilateral relations, during the 1990s France systematically advocated the interests of its client states in the international arena and in particular in the EU. Since Chirac's re-election, a substantial increase in the amount of the economic aid has been promised. However, delivery on this promise has not yet begun to materialize (OECD 2003: 248).

In summary, development assistance has been one of the main tools in the French Africa policy. Therefore, it is not surprising that until the early 1990s France was among the largest donors measured by the aid compared to GNI. However, from the early 1990s, the relative share of aid given by France has been cut quite significantly from about 0.6 per cent to around 0.3 per cent. The basic reason for the dramatic reduction has been domestic economic problems in France herself. To this can be added that the success of French aid in promoting development in Africa has at best been limited. French assistance has to a large extent financed the patron-client networks that make up Françafrique. Thereby, development assistance has contributed to restrict fundamental changes both within Africa and in the relationship between France and Africa. However, the dramatic reduction in French aid seems to signal a serious commitment to carry out fundamental changes in the traditionally strong relationship.

\section{The challenge of state-building}

When France granted independence to its African colonies, the priority was to help the new governments to build their states in order to transfer effectively the responsibilities to the new African elites. A considerable amount of money was devoted to technical assistance, and one of the main goals of this type of assistance was to help set up and develop new systems of education in order to train the new elite. This was first done through a policy of funding scholarships, which started before independence. Later it was done by progressively establishing schools, high schools and universities. A 
considerable number of French teachers and professors were sent to African countries until gradually they were replaced by a new generation of educated young local scholars. At the same time, many French civil servants were seconded to African administrations until they were replaced by the newly trained local elite. It is obvious that France was trying to reproduce its own educational, legal and administrative systems in the newly independent countries. No doubt, the decision-makers were thinking that this was in the interest not only of France but also of African countries.

The replacement of the French civil servants, teachers and university professors took more or less time depending on the pressure of the African elite who were eager to take over the higher positions of the state. Through the strong presence of technical assistants everywhere within the administration, France could exercise an important influence both direct and indirect on the African actors and their policies. Probably, they sincerely and naively hoped that this would be the way to build new, modern and efficient African administrations. But rather soon it became clear that the strategy was a failure. The result was the development of a neo-patrimonial state, a bureaucratic state in appearance, that became patrimonialized by its incumbents (Médard 1982, 1991).

The behaviour of the African civil servants was characterized by a total lack of a sense of responsibility and professional consciousness, which inevitably lead to widespread corruption. This was clear right from the start; as early as 1962, René Dumont made the point that development was a myth and an illusion if the elite were to behave in this manner. But such an observation was taboo within the French elite. Not only was it considered politically incorrect (even if the expression did not exist at that time). It was politically inopportune. It was simply not an issue for those in charge of African affairs. There was at minimum a sort of passive complicity between African and French elites on the matter, and at the higher decision-making levels there was active cooperation in corruption itself.

It is only from the middle of the 1990s, following evolutionary reforms at the World Bank and in European institutions, that questions of corruption and good governance appeared on the official French agenda. In the Ministry of Cooperation, a department of developpement institutionnel was created with the objective of promoting good governance in African administrations, and via the Cotonou agreements, France associated itself with the new conditionalities of good governance.

In summary, France originally relied heavily on technical assistance in its support for the new African governments. Based on the idea that France had a special mission civilisatrice in relations with Africa, it can hardly be surprising that France simply exported its own system of education and public administration. The strong presence of French teachers and civil servants contributed to a situation wherein France could exert immense influence on the course of development in the new states. In spite of the theoretical possibility of exerting influence of their own, African civil 


\section{Jean-François Médard}

servants behaved in a way that crippled the state into a patrimonial and bureaucratic entity. It was not until the mid 1990s that the French authorities began to criticize this state of affairs openly and to press for administrative reforms.

\section{The challenge of democracy}

When her African colonies were granted independence, France was officially supporting democracy in the new states. The new constitutions, written by or with the help of French constitutionalists, were very close to the model of the constitution of the Fifth Republic. Very rapidly, one-party systems replaced multiparty systems and military coups became endemic in a considerable number of African countries. However, the nature of African political regimes was not an issue for France. It was only when international public opinion was aroused by gross abuses of human rights that French authorities felt obliged to intervene in order to protect her image. This is what happened when President Giscard d'Estaing organized operation 'Barracuda' to dislodge his former friend, emperor Jean-Bédec Bokassa, after he committed atrocities against children in the Central African Republic. It is not a coincidence that France was the last Western country to break off relations with Macías Ngema of Equatorial Guinea, one of the worst dictators Africa has known.

France has never been seriously interested in human rights in Africa. Basically, French governments were ready to support any kind of African regime if this was felt to be in the interest of France. Foccart has been accused of supporting many of the military coups that took place in Africa. He certainly did not do all that he has been accused of, but he was almost certainly involved in the coups that took place in Guinea, Benin and the Comoros. Many coups could not have happened without at least the tacit agreement, if not the active support of French authorities. This is not surprising given that it was the firm belief of the French authorities that strong men in power were the best guarantee of political stability.

When democratic mobilization and transitions began in the early 1990s, French authorities had not anticipated such developments and were taken by surprise. While in June 1990 in Dakar the then mayor of Paris President Chirac declared that 'Africa was not ripe for democracy' after six months of hesitation and then very reluctantly, President Mitterrand had decided in his La Baule speech to support the movement towards democracy. He declared that aid would be given with priority to democracies. He added, though it was not noticed at the time, that each country will follow its own pace. Nevertheless, it was a turning point. Previously he had said 'no democracy without development'; now he was saying 'no democracy without development and no development without democracy'. This considerably accelerated the pace of transition in francophone Africa. It was the French ambassador who suggested to the dictator in Benin, Mathieu Kerekou, the solution of holding a Conference Nationale, which was then followed by many francophone 
countries. A national conference was a mixture of French revolutionary Etats généraux and traditional African palaver.

Soon it became obvious that there was a considerable discrepancy between the words of La Baule and the practice of Mitterrand. In reality, there was no 'democratic rent' and the policy was ambiguous, often contradictory and even more often, covertly in favour of the autocrats. Typical of this is the fact that the actual amount of aid given, which was supposed to be conditional on progress toward democracy, has been higher for the countries where the pace of that transition has been most criticized. This was the case, among others, with Gabon and Cameroon. The aid given for the elections was not only material aid. In the case of Niger, Chad, as well as Cameroon, and Gabon, there was an active if covert complicity with the frauds that distorted the results. In addition, the French representatives on the electoral commissions supported by France were handpicked to ensure that commissions arrived at the right conclusions, in favour of the incumbent dictator. Of all the commissions, the French-staffed ones have been the most flexible about the regularity of the elections.

In some cases the policies followed by the French authorities were totally incoherent. This was the case in the Central African Republic, where at one point the French authorities were fighting among themselves about how to organize elections. In Togo, the French administration and army helped as much as they could to keep President Guassingbé Eyadéma in power. When Eyadema staged a coup de force against the prime minister elected by the Conference Nationale, France did not move. Apparently this was because at the time it was judged more opportune to declare a duty to respect Togo's sovereignty. After the transitional period, the attitude of French authorities was still not very clear. In Côte d'Ivoire, the French army was almost sent to help Konan Bédié. This was the intention of President Chirac, as advised by Michel Dupuch, a former French ambassador in Côte d'Ivoire and a good friend of Bedié. However Prime Minister Jospin opposed it. In the Central African Republic, the French army finally left the country and was replaced by the Libyans. In Congo-Brazzaville, things went rather further. Chirac played the card of Denis Sassok Nguesso, the former dictator who had been fired by the Conference nationale, against Pascal Lissouba, the elected president. Some managers of Elf supported Lissouba, while the core of the company backed Nguesso. At the same time, Chirac gained the support of the Angolan president, José Eduardo dos Santos, whose military intervention was decisive in favour of Ngesso. The civil war, thus covertly encouraged by Elf and the French presidency, caused more than 100,000 deaths.

More recently, France supported President Didier Ratsiraka in Malagasy until the end. When all other foreign countries were present at the national celebration in Antanarivo, France was the only absentee. In the elections in Senegal, France was neutral, in spite of the close ties between President Abdou Diouf and Chirac. However, in that case Wade was not perceived as an enemy of France and had good connections with the French right. And in 


\section{Jean-François Médard}

the case of the latest elections in the Côte d'Ivoire, the French political class was completely divided. Once again with the issue of democracy, the priority was to help friends and fight those who were perceived as enemies, with the main criterion used to distinguish the latter whether or not their grouping was supported by the USA.

In summary, for more than three decades France had not been particularly interested in the issue of democracy and respect for human rights. However, after the fall of the Berlin Wall, officially France began to support the transition to democracy in its former colonies. However, it soon became clear that when it came to the issue of democracy there was considerable distance between words and deeds. The French position and hence its policy of support for different regimes was highly inconsistent; moreover, it was essentially impossible to predict what French policy would be from one case to another. In all probability, this is to be explained by the fact that genuine support for promoting democracy and human rights in Africa was in reality extremely limited, among the French political elite, including the institutions and people involved in policy-making. Also, the lack of consistency and predictability within this particular policy field has to be explained by reference to the unclear division of labour among the official institutions involved.

\section{Concluding reflections}

France adjusted successfully to decolonization for 30 years, but could not avoid a deep crisis in Franco-African relations in the 1990s. This has led to an acceleration of the long-term decline in French influence and forced a reform of its system of cooperation. Embedded in the comfortable routine of Françafrique which at first sight seemed to function well, France had been unable to appreciate that, beneath the appearance of continuity, changes were in train at both the local and the global level. Paris simply did not understand the depth of the economic crisis both at home and in Africa, nor of the political crisis that followed.

The French elite was unable to devise a new policy based on a re-evaluation of French interests in Africa in the new global environment that followed the end of superpower bipolarity. In spite of the fact that reform was initiated in the mid-1990s, this reform is far from being brought to fruition. Moreover, the implementation of policy is not only inconsistent; on numerous occasions it is difficult to understand. It can be argued that the inevitable changes in French policy that have been made are principally the result of non-decisions taken on a daily basis, rather than the expression of a new policy based on a new analysis.

If any consensus within the elite developed during the 1990s concerning the urgent need to reform Africa policy, it was only that the former policy was worn out and that the balance of its cost and benefits was negative for France. However, the costs of Africa policy will nevertheless exert constant pressure 
to continue the reform process. This process would be helped on its way if French policy-makers were able to convince the European Union to take on increasing responsibility for Africa, both as far as economic assistance is concerned and also, and not least, the crucial issues of stability and crisis management. Finally, it is possible to conjecture that during the 1990s the old consensus within the French elite concerning Africa may very well have been breaking down. And maybe, just maybe, this crumbling unanimity on the French mission civilisatrice could ensure that the reform process will maintain its momentum.

\section{References}

Bach, D. C. (1986) 'France's Involvement in Sub-Saharan Africa: A Necessary Condition to Middle Power Status in the International System', in A. Sesay (ed.), Africa and Europe, London: Croom Helm, 75-85.

(1990) 'Un système autonome de relations: la France et l'Afrique du Sud, 1963-1977', in D. C. Bach (ed.), La France et l'Afrique du Sud, Paris: CreduKarthala, 173-202.

Bellescize G. de (1999) 'Le maintien de la paix en Afrique: la France et le programme Recamp', Afrique contemporaine, 19 (3), 7-28.

Bourmaud, D. (2000) 'La coopération française en Afrique', in Observatoire permanent de la coopération française, Rapport, Paris: Karthala.

Caumer, J. (1999) Les requins, Paris: Flammarion.

Chafer, T. (2001) 'French African Policy in Historical Perspective', Journal of Contemporary African Studies, 19 (2), 165-82.

Cumming, G. (1996) 'French Aid to Africa: Toward a New Consensus?', Modern and Contemporary France, NS4 (4), 453-62.

Le Floch-Prigent, L. (2001) Affaire Elf, affaire d'Etat, Paris: Le Cherche Midi Éditeur.

McKinnon, R. and Charlton, R. (1996) 'Marching Toward Multilateralism?: The Franco-African Military Relationship in the 1990s', Modern and Contemporary France, NS4 (4), 463-70.

Marchal, R. (1998) 'France and Africa: The Emergence of Essential Reforms?', International Affairs, 74 (2), 355-72.

Médard, J.-F. (1976) 'Le rapport de clientèle', Revue française de Science Politique, 26 (1), 103-31.

(1982) 'The Underdeveloped State in Tropical Africa: Political Clientelism or Neo-patrimonialism?', in C. Clapham (ed.), Private Patronage and Public Power, London: Francis Pinter, 125-72.

- (1991) 'L'Etat néo-patrimonial en Afrique noire', in J. -F. Hédard (ed.), Etats d'Afrique noire, Paris: Karthala, 323-53.

_ (1997a) 'La corruption internationale et l'Afrique sub-saharienne: un essai d'approche comparative', Revue Internationale de Politique Comparée, 4 (2), 413-40.

_ (1997b) 'France-Africa: Within the Family', in D. Della Porta and Y. Mény (eds), Democracy and Corruption in Europe, London and Washington: Pinter, 22-34.

(1999) 'Les avatars du messianisme français en Afrique', L'Afrique politique, Paris: Karthala, 17-34. 


\section{Jean-François Médard}

_-(2002) ' "La politique est au bout du réseau", questions sur la méthode Foccart', October issue on Jacques Foccart of Cahiers du Centre de recherches historiques (EHESS-CNRS).

OECD (1995) Efforts and Policies of the Members of the Development Assistance Committee. Development Co-operation 1994 Report, Paris: OECD.

- (2003) Efforts and Policies of the Members of the Development Assistance Committee. Development Co-operation 2002 Report, Paris: OECD.

Ottenheimer, G. and Lecadre, R. (2001) Les frères invisibles, Paris: Albin Michel.

Péan, P. (1990) L'homme de l'ombre, Paris: Fayard.

Prunier, G. (1997) Rwanda 1959-1996, histoire d'un génocide, Paris: Editions Dagorno.

Renou, X. (2002) 'A New French Policy for Africa?', Journal of Contemporary African Studies, 20 (1), 5-26.

Shaun, G. (2000) 'The French Military in Africa: Past and Present', African Affairs, 99, (396), 435-48.

Smith, S. and Glaser, A (1997) Ces messieurs Afrique 2, des réseaux aux lobbies, Paris: Calmann-Lévy.

Verschave, F.-X. (1994) Complicité de génocide? La politique de la France au Rwanda, Paris: La Découverte. -(1998) La Françafrique, Paris: Stock.

(2000) Noir silence, Paris: Les Arènes. 


\title{
4 From Realpolitik to the Third Way \\ British African policy in the new world order
}

\author{
Gordon D. Cumming
}

The end of the Cold War transformed global politics and enabled Western governments to rethink their foreign policies towards black Africa. In this changing great-power environment, the British Conservative government under John Major (1990-97) was quick to reject the 'conventional wisdom' of the Cold War years and to recognize the need to 'improve and adapt' its 'response mechanisms' to Africa's crises. The Labour administration under Tony Blair, in power since 1997, has also emphasized the need for 'new thinking' on Africa (Hain 1999) and has promised to give the African continent 'a new priority on the international agenda' (Lloyd 1999).

Not surprisingly, these claims have led commentators to look for changes in British Africa policy. Most scholars, however, have limited their analysis to particular aspects of UK-African relations, such as development aid (Cumming 2001) or military assistance (Rouvez 1994). Others have focused on Britain's actions in specific African states like Zimbabwe (Taylor and Williams 2002). This chapter will provide more of an overview of British African policy and will assess how far this has adapted to the challenges of a new world order and of a post September 11 world. It will outline the main phases of UK-African relations and identify major changes in the last decade or so. It will then explain these changes and account for any broad continuity in policy. Finally, it will look at 'ideological' differences between the Major and Blair governments and examine how far these have marked Britain's response to Africa's challenges.

\section{Historical context}

There have been three broad phases in UK-African policy: the colonial era; the post-colonial period (1957-89); and the post Cold War phase (from 1990 onwards).

The colonial era dates back to Britain's conquest of large swathes of Africa in the nineteenth century. Although never as important as Asia, this continent did include commercially useful territories like South Africa and Nigeria. Africa did, moreover, form part of an Empire, which even after the Second 


\section{Gordon D. Cumming}

World War remained one of Britain's three foreign policy priorities - the other two being the US and Europe.

British colonial practice in Africa is often deemed to have been noninterventionist. Unlike France, Britain assumed that her tutelary obligation would end one day and operated a low-cost system of indirect rule, which allowed African populations a say in their own affairs. Yet, while the British respected most local practices, they left the indigenous peoples in no doubt that political authority rested with the Colonial Office. They did not rule out military intervention to suppress African uprisings (as in Kenya in the 1950s) and made sure African territories produced the raw materials needed for UK industrial growth. While the British gradually relaxed their terms of trade, they maintained their hold on African economies through post-war economic assistance and currency pooling arrangements like the sterling area.

The post-colonial period began in black Africa in 1957 when Britain, aware of her declining world power status and anxious to respond to rising anticolonial sentiment, granted independence to Ghana and set in motion a decolonization process that lasted over two decades. Relations with Africa were initially given priority as London sought to ensure the survival of nascent African states, protect investments and finance land transfers from British settlers to Africans. To these ends, Britain replaced her complex colonial bureaucracy with new structures, notably the Overseas Development Ministry in 1964 and a unified diplomatic service in 1965. The UK also set up sizeable bilateral economic and military assistance programmes that focused heavily on the 17 African countries that had experienced British rule (Lancaster 1999: 134).

Yet Africa soon became a region of 'declining importance' (Rouvez 1994: 84), as relations with America and Europe - particularly after Britain's entry into the Common Market in 1973 - took precedence. This decline was reflected in aid and trade patterns. By 1987, Africa was receiving only $\$ 325$ million in aid from the UK, a mere 16 per cent of the $\$ 2,046$ million supplied by France. The continent was, moreover, receiving no more than 3.2 per cent of UK exports and providing only 1.9 per cent of UK imports (Clapham 1996: 87). Britain's increasing indifference was also apparent from her readiness to ignore the demands of African leaders whenever vital interests were at stake. A case in point was the stubborn refusal of British Prime Minister Margaret Thatcher (1979-90) to respond to Commonwealth pressure and intensify sanctions against South Africa, which was the one African country where Britain did have substantial economic and strategic interests because of the million settlers with the right to return to the UK.

There were, nonetheless, times when the UK had to take a more proactive stance. These were moments of crisis such as that provoked by Rhodesia's Unilateral Declaration of Independence in 1965. Britain initially imposed an oil embargo and later took the lead in securing agreement on a framework for independence. Yet while Britain was prepared to respond to international 
pressure for action on Rhodesia, she refused to consider military options and stuck doggedly to her 'quick in, quick out' policy during the Lancaster House talks of 1979-80 (Rouvez 1994: 269).

At other times, British policy was marked by a much clearer reluctance to intervene. Anxious to avoid allegations of neo-colonialism, London looked the other way when, in the 1960s, most African regimes abandoned democracy. The UK also turned a blind eye when Ugandan President Idi Amin engaged in large-scale human right abuses in the 1970s and when Zimbabwean President Robert Mugabe authorized killings in Matabeleland in the 1980s. Indeed, London was even prepared to increase assistance to regimes with poor human rights records where this served her geo-political interests. Thus, Britain stepped up aid to Rhodesia's neighbours in the 1960s and 1970s in an effort to win diplomatic support for her policy of isolating the white minority regime (Lancaster 1999: 134-5). Subsequently, the UK intensified military assistance to countries bordering South Africa, in an attempt to counter destabilization by the apartheid regime and to temper African criticism of Mrs Thatcher's stance on sanctions.

The UK was equally careful to avoid open-ended military activity. Having withdrawn forces from East of Suez by 1971 and abandoned her last African military base, Simonstown, in 1975, London had neither the will nor the capacity to become embroiled in African conflicts. Apart from her efforts to stabilize Kenya, Tanzania and Uganda during the 1963-4 East African mutinies, Britain avoided military combat and steered clear of Cold War trouble spots in the Horn and Southern Africa. Britain instead confined her activity to supplying arms (e.g. Nigeria 1967-70) and deploying British Military Assistance Training Teams (BMATTs) on short-term contracts.

The UK was also wary of intervening in African economies. The Thatcher Administration did link bilateral aid to World Bank structural adjustment programmes. But it was reluctant to inflict hardship on Africa's poor and turned a blind eye to slippage on World Bank conditions, particularly in former colonies like Kenya (Mosley 1991: 40-2).

The post-Cold War era can itself be divided into two phases, namely the periods before and after the September 11, 2001 terrorist attacks on the US. The first phase was marked by two new trends: a 'multilateralization' of UK-African relations, and a growing propensity for Britain to intervene in African internal affairs. The multilateralization process was evident in the UK's increasing tendency to use the European Union (EU) and World Bank to press for African reforms. It was also reflected in Britain's greater readiness to raise African debt issues in the Group of $8(\mathrm{G} 8)$ and in her rapprochement with the Commonwealth, which became, after the end of apartheid, more receptive to British calls for charters on human rights and free trade. It was equally clear from UK cooperation with France - notably since the 1998 Saint-Malo agreement - on conflict prevention in Africa.

Britain's growing propensity to operate through multilateral forums inevitably made it easier for her to intervene in African affairs without taking 


\section{Gordon D. Cumming}

on 'tutelary' obligations and without ruining her bilateral relations with African countries. As will be seen later, the UK introduced a policy of political conditionality whereby aid was linked to political reforms by African governments. Britain also proved more willing than in the past to become involved in resolving African conflicts. Furthermore, the UK showed greater determination than in the 1980s to push through economic liberalization programmes and used the Special Programme of Assistance for Africa to provide extra financial support to African reformers.

Since September 11, 2001, both these trends have become more pronounced, and British African policy has come to be marked by 'an increased awareness of ... security concerns' (Interview with senior FCO official, September 2003). That the multilateralization of UK-African relations has intensified can be inferred from Britain's growing involvement in the G8, where she has pledged, at the 2002 Kananaskis summit, to spend $£ 1$ billion on aid to Africa by 2006, and where she has lobbied successfully for a generous response to the African-led recovery programme, the New Partnership for Africa's Development (NEPAD). That Britain's readiness to intervene in African affairs has increased can be seen in her participation in EU peacekeeping operations in the Democratic Republic of Congo (Independent, 13 June 2003) and in her recent commitment never to allow a repeat of the kind of genocide that occurred in Rwanda in 1994 (Blair 2001).

Finally, as regards the new security dimension in UK-African policy, this has been reflected in Britain's efforts - through her chairmanship of the UN's Counter Terrorism Committee (CTC) and her provision of technical assistance - to ensure that Africa and the rest of the international community draw up anti-terrorism legislation (in compliance with Security Council Resolution 1373) and clamp down on money laundering and other sources of terrorist funding. It has also been apparent in the UK's overhaul of travel advice to visitors to Africa and its tightening of security at embassies, notably in East Africa. It has, moreover, been evident in Britain's growing emphasis on failed and failing states, whose porous borders, weak government institutions and inadequate law-enforcement agencies make them seedbeds for terrorism (e.g. Liberia) as well as safe havens and transit routes for terrorists (e.g. Sudan, Somalia) (Harman 2002).

It would, however, be wrong to exaggerate the extent to which UK-African relations have changed. The fact is that these relations are still essentially bilateral and continue to be conducted largely through high commissions, embassies and aid missions (Vachers 2002: 693-730). Rather than merging her missions with those of other European powers, as the logic of the European Common Foreign and Security Policy might suggest, Britain has opened new embassies in Africa (e.g. Eritrea in 2001, Guinea in 2003) along with a new Development Division in Pretoria (1993). The UK has, moreover, failed to apply political conditionality consistently and has eschewed punitive aid sanctions in favour of positive support for political reform. Britain has also remained cautious about becoming militarily entangled in African trouble 
spots (e.g. Rwanda, 1994 or Liberia, 2003) and has remained reluctant to insist on rigorous adherence to World Bank conditions. Indeed, where countries have gone off track with their economic programmes, London has looked for progress in other areas like democratic reform (e.g. Malawi in the mid 1990s) and privatization policies (e.g. Zambia in December 2000).

And while Britain has 'inevitably shown a greater interest in security' issues relating to Africa (interview with senior FCO official, September 2003) and in the possible link between poverty and terrorism, she has also recognized the limited nature of the threat to the West posed by Africa (interview with senior FCO Official, September 2003). The UK has come to see this continent, particularly sub-Saharan Africa with its generally moderate Muslim populations, as a victim of terrorism and a 'soft target' for extremists. This view has been confirmed by World Bank estimates of the negative global economic impact of September 11 and by the November 2002 bombing of the Paradise Hotel in Mombasa (DFID 2002: 8).

\section{Accounting for change}

A number of factors have contributed to the recent changes in UK-African policy. The failure of structural adjustment, the debt crisis and the nearcollapse of the African neo-patrimonial state all pointed to the need for a fresh approach. The legalization of the African National Congress in 1990 also allowed Britain to be more critical of African human rights abuses without being accused of double standards over her policy towards apartheid. But the most important factors have been the end of the Cold War and the atrocities of September 11.

The end of East-West rivalry reduced Africa's strategic significance and enabled Britain to push for democratic reform without the fear that African leaders would be driven into the Soviet camp. It also lifted the lid on ethnic and civil conflicts and seemed to legitimize Western interventions in war-torn African states. In addition, it exposed the failure of centrally planned economies and appeared to justify UK efforts to integrate marginalized African states into the global economy. Finally, it freed British policy-makers from the ideological straitjacket of the Cold War and allowed them to take stock of the enormous challenges facing Africa. In so doing, it helped convince them that Britain could only make a difference by acting 'as a catalyst and advocate for positive change in Africa in multilateral bodies' (Lloyd 1999).

As for September 11, this has led to a fundamental shift in the international strategic environment. As Tony Blair pointed out: 'The kaleidoscope has been shaken. The pieces are in flux' (Scotland on Sunday, 29 December 2002). In the case of UK-African policy, September 11 underlined the fact that 'the security of each of us depends on the prosperity of all' (Blair 2002). It also underscored the need to give greater priority to Africa to ensure that it did not 'go the way of Afghanistan' (Daily Telegraph, 6 February 2002). 


\section{Constraints on change}

Ultimately, however, none of the above factors was enough to transform UK African policy. This is hardly surprising given that Britain was never really a Cold War power in Africa (McKinlay and Little 1978) and that September 11 was always likely to impact less on African policy than on UK relations with the Middle East and Asia, which are more strategically important in the war on terror.

At the same time, there are good reasons why the UK has not pushed too hard for political and economic reform. These revolve around Britain's longstanding interests in Africa, which might be damaged by an overly interventionist stance. These interests have included a desire to spread British culture and values, and a moral concern to help the world's poorest continent. British economic concerns have centred on trade and investment in pivotal African states - notably South Africa, Nigeria and Kenya. UK investment in South Africa, Kenya and Nigeria is worth $£ 14$ billion, $£ 1.5$ billion and $£ 1$ billion. Two-way trade totalled over $£ 3$ billion (Lloyd 1999), $£ 385$ million and $£ 752$ million (www.fco.go.uk). Political considerations have included the fact that Africa offers a bloc of friendly votes in the UN; a source of allies in the coalition against terrorism; and a valuable sphere of influence for Britain at a time when her other claims to world power status (her permanent seat in the Security Council and her nuclear defence capacity) are being challenged by rival powers. Finally, strategic interests have focused on minerals like oil and uranium; on the security of British expatriates; and on the increasing flow of immigrants from failed states like Somalia and Sierra Leone. As to the number of asylum seekers, it doubled from 10,295 in 1993 to 20,710 in 2001, with sharp rises in applications from Somalia and Sierra Leone (Heath and Hill 2002: Table 2.1).

\section{A moderating influence: the policy-making process}

The policy-making process has also served to limit recent changes in UK-African policy. This process has involved three main actors: the executive, parliament and the civil service.

\section{The executive}

The executive comprises the Prime Minister and his ministerial team, who are traditionally assumed to determine foreign policy through meetings of the Cabinet and its committees as well as through consultation with civil servants and special advisers. The executive has unquestionably helped to determine the recent direction of African policy. It was the Conservative Foreign Minister, Douglas Hurd, who launched the policy of political conditionality (Hurd 1990); and it was the Labour Foreign Secretary, Robin Cook, who subsequently emphasised the need for a less-confrontational approach based 
on 'dialogue' (Cook 2000). It was also Conservative Prime Minister John Major who, in 1991, pressed hardest for military operations to create 'safe havens' for the Kurds in Northern Iraq; and it was Labour Premier Tony Blair who later built on this precedent and set out 'new rules' for military action overseas (Blair 1999a). It was, moreover, Conservative Development Minister Lynda Chalker who ensured Britain's continuing attachment to economic liberalization programmes; and it was the Labour Secretary of State for International Development (1997-2003), Clare Short, who - together with Chancellor Gordon Brown - subsequently tempered this with a strong emphasis on pro-poor policies.

It would, however, be wrong to overplay the influence of the executive. For a start, the Cabinet has been bound by its collective responsibility to Parliament and has had to take on board the views of various Secretaries of State for Defence and for Trade and Industry. The latter have sought to ensure that the government's stance on human rights does not jeopardize commercial interests; that Britain's armed forces are not heavily deployed in parts of the world (e.g. Africa) that are marginal to her security interests; and that the promotion of free markets and pro-poor policies does not interfere with the demands of British business for aid subsidies and export licences. This last concern was illustrated in 2001 when the Defence and Trade and Industry Ministers secured, on behalf of British Aerospace, a licence for the sale of an over-priced military air traffic control system to one of the world's poorest countries, Tanzania.

Significantly too, the executive has had neither the time nor the inclination to maintain the momentum behind recent shifts in African policy. While ministers have been willing to attend high-level international gatherings and be proactive at times of crisis such as that provoked by Zimbabwean President Mugabe's policy of occupying white-owned farms, they have simply not had time to check that their initiatives have been followed through on the ground. The weekly Cabinet agenda has, moreover, been too overloaded with domestic and foreign policy priorities for ministers to devote much attention to a region that is never more than a marginal issue in UK election campaigns.

\section{Parliament}

Parliament will be taken to comprise the Houses of Commons, the Lords and the members of each House. According to 'the liberal language of the constitution', Parliament is supposed to control the executive and hold ministers accountable (Morrissey et al. 1992: 45). In terms of African policy, parliament has indeed sought to hold the government accountable and to ensure that it lives up to its post Cold War rhetoric. Government backbenchers and opposition MPs have, both through their tabling of questions and their work in select committees, exerted pressure on ministers to apply political conditionality consistently; to intervene in African humanitarian crises; and to alleviate the hardship caused by economic austerity programmes. 


\section{Gordon D. Cumming}

Yet it would be wrong to overstate the influence of Parliament. The fact is that this legislative forum has only really played a prominent role when it has been investigating scandals like the 1998 Arms to Africa Affair - where Foreign Office officials were found to have colluded with mercenaries to supply arms to the former president of Sierra Leone, Ahmed Kabbah, in defiance of a UN embargo. At other times, Parliament has been reluctant to debate African issues, which are a lower priority for MPs than issues arising out of their domestic constituencies. And while parliamentary select committees have been more proactive, their influence has been limited by their need to work by consensus and their inability to force governments with reasonable majorities to follow their recommendations.

Despite its limitations, parliament has served as a key forum through which the African development and business lobbies have operated. The most vociferous actors in the development lobby have been non-governmental organizations (NGOs) like Oxfam. These organizations have, through their evidence to select committees and briefing of MPs, pressed the government to intervene more strongly against brutal African regimes; to halt arms sales to countries engaged in regional conflicts; and to increase support to African countries struggling with economic reform. Yet while NGOs have enjoyed good working relations with key ministries like the Department for International Development, their influence has continued to be limited by their tendency to operate through Parliament, which is weak in relation to the executive, and by their propensity to engage in 'isolated development projects', which are not - in the UK government's view - the most effective way to tackle global poverty (Legum 1999: A116).

The business lobby has, arguably, been better placed to exert influence, thanks to its direct contacts with ministers and officials within the powerful Department of Trade and Industry. This lobby includes individual exporters and commercial forums like the Confederation of British Industry. It has publicly supported UK efforts to promote democracy, prevent conflicts and open up markets in Africa. Yet, while it has accepted government guidelines on ethical trading, its primary concern has been with winning arms contracts, securing export credits and maintaining stable trade relations with African countries. This was illustrated when the Anglo-Dutch consortium Shell, fearing nationalization by the Nigerian government, stepped back from intervening strongly on behalf of Ken Saro-Wiwa or the other activists hanged by the Abacha regime.

\section{The civil service}

The main government departments concerned with African policy are the Foreign and Commonwealth Office (FCO), Department for International Development (DFID), Department of Trade and Industry (DTI), Ministry of Defence, the Treasury, and Home Office, whose primary interests lie, 
respectively, in diplomatic relations, development, trade, military support, debt reduction, and immigration.

The civil service or 'Whitehall' is traditionally assumed to formulate and implement government policy within the narrow parameters set by ministers. This assumption underestimates the extent to which civil servants have shaped and slowed down government initiatives during the post-Cold War era. In the early 1990s, African policy was 'in practice, the domain of permanent officials at the Foreign and Commonwealth', and junior Conservative ministers would 'often merely approve recommendations of career officials on African affairs' (Rouvez 1994: 197). Under the Blair Administration, the International Development ministry has taken the lead on African policy and put flesh on the bones of Labour's commitment to build peace, prosperity and democracy in Africa. Propelled into the limelight by its outspoken former Minister, Clare Short, the DFID has assumed a cross-governmental brief on development issues and played a key role in appointing ambassadors to some African countries.

It can be inferred from the above that Whitehall departments have been keen to expand their realm of influence. It cannot, however, be assumed that they have used their influence to promote changes in African policy. Conscious of the risks posed to their careers and departments by radical reforms, civil servants have reacted cautiously to recent changes in African policy. FCO officials were, for example, quick to tone down the rhetoric of Conservative ministers on political conditionality and were 'mealy mouthed' (Burnell 1993) in their demands for African democratic reform. The DTI has, similarly, campaigned behind the scenes for a relaxation of the Labour government's ethical criteria for granting export cover (Guardian, 26 January 2000).

Significantly too, Whitehall has been well-placed to ensure that its reservations are reflected in policy outcomes. For a start, civil servants have been charged with drawing up guidelines for policy implementation and coordinating African policy through inter-ministerial forums. During these bureaucratic exercises, they have emphasized standard operating procedures, struck pragmatic compromises and watered down ministerial initiatives. Second, Whitehall has benefited from its institutional memory, which is encapsulated in the expertise of its aid and diplomatic staff, many of whom spend several postings in Africa (KirkGreene 2000). Finally, civil servants have enjoyed considerable policy-making discretion thanks to public inertia about day-to-day events in Africa and to the secrecy surrounding the workings of the FCO. The Arms to Africa scandal was an extreme example of this secrecy, with Foreign Office mandarins withholding information both from Parliament and their own ministers (Foreign Affairs Committee 1999).

To sum up, the British policy process has operated in crisis equilibrium mode, when the executive and parliament have been heavily involved in shaping policy, and in routine equilibrium mode, when the civil service 


\section{Gordon D. Cumming}

has been working to ensure a business-as-usual approach to UK-African relations.

\section{Britain's policy style}

It follows from the above that Britain's reactive and pragmatic policy-making 'style' has served as an additional constraint on changes in African policy. This low-key style typified the Major government's handling of African policy. With a slender parliamentary majority and riven by internal party strife, the last Conservative government viewed Africa as a low priority (Rouvez 1994: 197). It displayed a lack of vision, a refusal to espouse grand principles and a reluctance to endorse UN development targets. Its approach was, moreover, marked by Afro-pessimism, a propensity to ignore or deal retrospectively with African crises and a conviction that Britain alone could do little to tackle Africa's problems.

The more media-conscious Blair administration has, amidst the euphoria surrounding its two landslide election victories, given African policy a higher profile and shown enthusiasm for bold initiatives like NEPAD. The Blair Government style has been marked by Afro-optimism and a conviction that Britain, as a 'pivotal' power (Blair 1999b), can make a difference in Africa. It has, moreover, been underpinned by frequent claims that Africa is now a 'priority' (Hain 1999; Lloyd 1999) and by a determination to take charge of African policy. In this latter context, the Blair administration has revamped the DFID and given its minister a seat in cabinet. Furthermore, it set up, in 1998, an independent think tank (the Foreign Policy Centre) and attempted to modernize the FCO by widening recruitment, setting performance targets and encouraging secondments from NGOs like Amnesty International.

\section{From Realpolitik to the 'Third Way'}

The above discussion has focused essentially on trends that have been common to the Major and Blair governments. This has been reasonable given the moderating influence of the civil service and the broad left-right consensus governing UK-African policy. It would, however, be wrong to assume that the policies of the Major and Blair administrations have been distinguishable only in terms of policy style. The fact is that there have been 'ideological' differences between the Conservative government, which based its policy on realpolitik, and the Labour administration, which has opted for a more ethical, if ill-defined, 'third way' stance on African policy.

The Major government's emphasis on realpolitik was reflected in its pursuit of narrow national interests, its attachment to sovereign statehood and its reluctance to become embroiled in African affairs where UK interests were not threatened. It was, equally, apparent in its propensity to emphasize African solutions to African problems and to view market forces as the panacea for Africa's ills (Rifkind 1996). 
The Labour administration's espousal of a 'third way' African policy has been evident in its rejection of 'narrow realpolitik' (Cook 1997) and its focus on the interdependence between the national and international interests. It has also been clear from Labour's refusal to accept the notion of unfettered sovereignty, its initial emphasis on the 'ethical dimension' of foreign policy, and its stress on Britain's 'duty to care' about Africa (Short 1997a). It has, lastly, been reflected in Labour's attachment to the idea of equal 'partnerships' with African regimes (Short 1997b) and its apparent readiness to challenge socialist and neo-liberal economic development models.

These conceptual differences should not be overstated: the Conservatives did play down their ethical concerns but did not follow an immoral policy towards Africa. Similarly, the Blair administration has not ditched realpolitik in favour of 'moralpolitik' (MacShane 2002) where moralpolitik is a 'form of cosmopolitanism which looks to replace the states system with a universal moral community' (Dunne and Wheeler 2001: 64). Blair has steered a middle path between the two. It follows that while 'ideological' differences have inevitably marked Britain's post Cold War African policy, they have not led the Major or Blair administrations to disagree about the nature of the challenges facing Africa. These challenges and the UK response to them are discussed below.

\section{Autocratic and corrupt government}

Britain's post-Cold War response to this challenge has involved positive and punitive measures to encourage democracy, respect for human rights and 'good government'. Under the Major administration the emphasis was on promoting neo-liberal democracy and African civil and political liberties. The realist assumption was that democratization would establish peace-loving African states, which would be easier to deal with and less dependent on aid. In support of this agenda, the Conservatives set up a Human Rights Policy Unit within the FCO and a Government and Institutions Department within the DFID. They also provided financial support for multi-party elections (e.g. South Africa, 1994) and promoted good government through civil service restructuring (e.g. Ghana) and anti-corruption commissions (e.g. Zambia). In addition, they bolstered human rights through assistance to the legal sector (as in Tanzania) and the creation of human rights centres (as in Gambia). And, where positive measures were not appropriate, they suspended aid to harsh regimes (e.g. Sudan, 1991) and governments which refused to democratize (e.g. Malawi, 1992).

Ultimately, however, the realist Major government was never fully committed to political reform and stopped short of imposing aid penalties in countries where the UK had important economic interests (e.g. Nigeria). Arguably, the Conservatives were never primarily interested in African democratization, but saw this as a means of promoting market reforms (Crawford 2001: 59-60). The indulgence with which they treated Ghana's 


\section{Gordon D. Cumming}

Jerry Rawlings and Ugandan President Yoweri Museveni, both champions of the free market but reluctant democratic reformers, would support this contention. So too would the fact that the Major administration avoided providing direct support to African opposition movements and failed to invest in African human rights organizations (ibid.: 126-49).

The Blair government has continued Major's policy of promoting African political reform but has emphasized economic and social alongside civil and political rights. It has continued to provide support for multi-party elections (e.g. Nigeria, 1999) while also stressing the need for greater democratic participation by the poorest groups. It has remained committed to good government, while giving this concept a pro-poor bias (DAC 1997: 21). It has, moreover, maintained Britain's focus on civil liberties, while also stressing the right of the poor to social justice and 'to education, healthcare and a livelihood' (Short 1997c).

The Blair government has been prepared to sign up to EU aid sanctions against states which abuse the electoral process (Togo, 2002), which hamper democratic development in neighbouring countries (Liberia, 2000) or which flout the rule of law (Zimbabwe, 2002). It has, however, steered clear of 'old style' conditionality (Vereker 1998: 14) and favoured a less confrontational approach based on dialogue. It has claimed to be following a third way between 'row' and 'kow tow' (Daily Telegraph, 15 November 1997) and promised that African partners who respect human rights will benefit from more aid, whereas other governments will receive less.

Yet, while Labour has successfully engaged in dialogue with erstwhile sponsors of terrorism like Libya, it has been unsure what do to when African governments have refused to enter into partnerships or have failed to fulfil their commitments as partners. In Kenya, it made no attempt to stop aid, or even arms sales, to the KANU regime, despite the latter's manipulation of the electoral process throughout 1997. In Nigeria, where General Sani Abacha ignored British demands, Labour shied away from imposing an oil embargo and even encouraged Nigeria to play a peacekeeping role in Sierra Leone between 1997 and 1998. Similarly in Zimbabwe, the UK did not emulate the US and suspend aid to Mugabe's regime in early 2000, even though the latter had wrecked the economy and embroiled Zimbabwe in the war in the Congo. It was not until Mugabe began encouraging the occupation of white-owned farms prior to the June 2000 Presidential elections that Labour finally halted arms sales and military assistance to Zimbabwe. By this time, however, 'the limits of British influence' had been 'sharply exposed' (Hill 2001: 347).

\section{Civil, ethnic and regional conflict}

Britain's post Cold War response has centred on measures to tackle the causes and symptoms of conflict. The Major government saw conflict resolution as a way of minimizing disruption to 'steady economic development' and of reducing the cost of post-war reconstruction (Hurd 1995: 7). It took some 
(limited) steps to address the immediate causes of conflict. Thus it threatened to reduce assistance to African states that made 'questionable military purchases' (John Major cited in the Guardian, 9 May 1990), worked to cut arms spending in Uganda and helped to demobilize soldiers in Angola. Its main focus, however, was on treating the symptoms of conflict. In this context, the Conservatives provided diplomatic support in peace negotiations (as in the Arusha Talks) and economic support for post-war construction (as in Rwanda). In addition, they provided police training to over 30 African countries and started deploying BMATTs more heavily outside anglophone Africa (e.g. Angola and Mozambique). Finally, they proposed the creation of an inter-African peacekeeping force, took part in UN peacekeeping missions (e.g. Angola, 1995) and helped to monitor of ceasefires in conflict-ridden countries (e.g. Namibia, 1989-90).

However, the last Conservative government was never strongly committed to conflict resolution. It saw this as a 'task for the future' (Hurd 1995) and undermined its own policy of discouraging 'excessive military expenditure' (Chalker 1991: 3) by selling tanks to Nigeria in 1994 (in defiance of EU sanctions) and by presiding over an alleged arms sale to Rwanda in 1996 (in contravention of a UN embargo). It was also quite prepared to allow France to play the role of peace broker in francophone Africa and to let NGOs take the lead in the post-war rehabilitation of Rwanda. Its African peacekeeping initiative was, moreover, almost immediately eclipsed by America's African Crisis Response Initiative, and its commitment to African peacekeeping operations remained shaky. Reluctant to risk soldiers' lives in a region of limited strategic importance, the realist Major administration simply refused to be dragged into ground operations in Somalia and actually dissuaded other Western countries from intervening in response to the genocide in Rwanda (Melvern 2000: 153).

The Blair government has, for its part, adopted a 'third way' approach to conflict resolution, focusing on the rights of people caught up in wars while emphasizing the dangers, in an interdependent world, of refusing to help. It has developed its capacity to handle conflicts by recruiting regional conflict advisers, appointing a cabinet sub-committee and creating a $£ 50$ million fund for African conflict prevention. It has used this capacity to tackle the root causes of conflict - especially poverty - and to address its more immediate causes. In this latter context, it has banned the sale of landmines and torture equipment, refused export cover for arms sales to the poorest countries and endorsed African initiatives like the West African Small Arms Moratorium. The Blair administration has also laid out new guidelines on arms sales; embraced the $1998 \mathrm{EU}$ arms code; and recently introduced a bill to tighten legislation on strategic exports. It has, moreover, sought to prevent diamonds from being used to fund wars in Sierra Leone, Angola and the Congo. To this end, it has organized conferences calling for a global diamond certification scheme and introduced a Green Paper on mercenaries - many of whom are paid in diamonds by bankrupt African dictators. 
The Blair government has been equally proactive in dealing with the symptoms of conflict. It has, actively brokered peace deals in the Great Lakes region; offered substantial economic support for the reconstruction of Rwanda; and committed over $£ 10$ million to peace building in Sudan (DFID 2003a: 76). It has, moreover, stepped up military assistance - notably to Sierra Leone where BMATTs are training a single united army - and increased the number of police officers available to the African security sector. Significantly too, the Labour administration has improved Britain's capacity to intervene militarily in Africa by undertaking a Strategic Defense Review in 1998, by committing itself to the creation of a European Rapid Reaction Force by 2003 , and by entering into a standby agreement with the UN, which earmarks British forces specifically for the purpose of emergency peacekeeping. More significantly still, the government has demonstrated a readiness to 'get actively involved in other people's conflicts' (Blair 1999a), even where British interests 'are not directly engaged' (Robertson 1997: 2). Its deployment of 1,300 troops to Sierra Leone in May 2000 was a case in point.

The Labour government has not, however, given conflict resolution priority over domestic political considerations. Thus, the Blair administration - to avoid reviving memories of the Arms to Africa affair - deliberately held up publication of its Green Paper on mercenaries until after the 2001 elections and excluded a planned bill on arms regulation from the Queen's speech in November 2000 (Guardian, 23 August 2000). The government has, moreover, brushed aside claims that its arms guidelines cannot be enforced and has played down reports that British weapons were falling into the hands of child soldiers in Sierra Leone (Daily Mail, 30 May 2001). Worse still, it has, at times, lapsed into pragmatic realism and authorized the sale of Hawks and other military items to countries involved in the war in the Democratic Republic of the Congo, including Zimbabwe, Namibia, Tanzania, and Uganda (Financial Times, 4 April 2000).

\section{Poverty and economic failure}

Britain's post Cold War response has involved a mixture of measures to tackle poverty and to promote economic liberalization. The Major government, whose 'wet' wing had never accepted Mrs Thatcher's view of aid as a 'handout', did attach some importance to alleviating poverty in Africa. Thus, it included 'directly targeted poverty reduction' among its overseas development objectives (ODA 1995); channelled more assistance through NGOs; and provided debt relief worth around $£ 50$ million a year during the 1990s (DAC 1997: 29).

The Major administration was never, however, primarily interested in poverty reduction and was reluctant to devote a sizeable share of UK taxpayers' money towards tackling African economic failure. Comforted by its belief in the virtue of self-help, it presided over a significant reduction in the UK aid budget as well as cutbacks in bilateral assistance to Africa. The aid 
budget fell from 0.31 per cent of Gross National Income (GNI) in 1989 to 0.26 per cent in 1997 (DAC 2001: 72). Bilateral assistance dropped from $£ 636$ million in 1989-90 to $£ 563$ million in 1995 (DAC 1997: 59). It also undercut its own focus on poverty by stretching aid across too many sectors and recipients (Healey 1997: 221), and by increasing the share from 23.3 per cent in 1990-1 to 27.1 per cent in 1995 of total UK assistance going to the EU - a donor that had no clear poverty strategy (DAC 1997: 56).

The Conservative government's real interest lay in promoting neo-liberal economic reform. It saw market forces as the engine for African growth and thought of the role of aid as being to encourage trade, to 'promote the right enabling environment for the private sector' (Chalker 1997), and to ensure that economic recovery programmes were not abandoned due to lack of donor support. Ultimately, however, the realist Major administration was not prepared to support free market competition whenever UK economic interests were at stake. As such, it resisted pressures to unilaterally untie bilateral assistance, refused to halt aid subsidies to British companies exporting to Africa and went along with the EU's policy of restricting South Africa's access to the European market.

The Labour government has, for its part, adopted a third-way approach to African economic failure, stressing Britain's 'moral duty to reach out to the poor' (Short 1997a) while pointing out that prosperity will also bring trade and other benefits to the UK. In line with this approach, Labour has made poverty reduction the overarching goal of the development programme and has trumpeted its attachment to the Millennium Development Goals on poverty reduction, health and education (DFID 2003a: 10-12). It has phased out the use of export subsidies as from 1998, unilaterally untied all UK aid as from 2001, and cancelled over $£ 1.2$ billion in debt owed by the poorest countries (DFID 2001). It has, moreover, bucked the downward trend in Western donor circles by promising 'step changes' in the overall aid budget, which is set to rise by an average of 8.1 per cent a year to $£ 4.6$ billion in 2006 (DFID 2003b: 9). Almost a quarter of this will be allocated to Africa.

The Labour administration has viewed poverty reduction as a goal in itself and has seen effective central governments - or 'enabling states' (Short 1997c) - as the key to ensuring wide access to essential services like education. In line with this thinking, it has qualified its support for the free market by stressing that globalization has to be 'managed wisely'; that the World Trade Organization (WTO) needs to be made to 'work for poor countries' (DFID 2000: 15 and 32); and that all international organizations should work together 'to create an international system which supports development' (DFID 2003b: 1).

It would, however, be wrong to overstate the Blair government's commitment to African development. It will, even by 2006, only have raised the aid budget to 0.4 per cent of GNI, well short of the UN target of 0.7 per cent (DAC 2003: 118). It has, moreover, failed to push for radical changes to international organizations and has continued to accept that debt reduction 


\section{Gordon D. Cumming}

should be tied to past performance on market reform, even though this has drastically slowed down the pace of debt relief. Finally, it has given unreserved backing to neo-liberal strategies like South Africa's Growth, Employment and Redistribution programme and has refused to accept that its calls for 'comprehensive trade liberalization' (DFID 2000: Paragraph 3.16) conflict with its poverty reduction strategy. In so doing, it has disregarded a large body of evidence that suggests that neo-liberal reforms widen the gulf between rich and poor and have negative social consequences for developing countries (Cornia et al. 1987; Chossudovsky 1997).

\section{Conclusion: whither British African policy?}

This chapter has provided an overview of UK-African relations and has shown how these relations have evolved from the time of colonial rule to the post-Cold War era. It has suggested that Britain has adopted a more interventionist policy and has attributed this to the end of the old world order and the events of September 11.

It has also demonstrated how the different ideological perspectives of the Major and Blair governments have affected Britain's response to Africa's challenges. The realist Conservative government was not averse to 'new thinking' on Africa's problems but was unwilling to invest in resolving them. The Labour administration has been more enthusiastic in its search for solutions and in its advocacy of a 'third way' between 'row' and 'kow tow', between excessive military interventionism and passive isolationism, and between neo-liberal and redistributive economic policies. But its thinking has remained rooted in realpolitik. This is clear from its refusal to countenance radical changes to the WTO and its overriding concern to maintain the existing neo-liberal economic system. It is also implicit in the fact that senior Labour ministers have spent considerably less time talking about Africa's chronic problems than they have addressing Western security concerns in countries like Iraq.

It is not clear what the future holds for UK-African policy. If, as seems likely, the Blair Government is re-elected for a third term, it should be well placed to develop its thinking on the third way, to modernize the civil service and to make Africa a genuine 'priority'. It could meet UN targets on aid, intervene more consistently in African crises through the European Rapid Reaction Force and take forward proposals for a Marshall Aid-type fund for world development (MacShane 2002).

There is, however, a danger that a Labour administration, hardened by years in office and without Clare Short at the helm of the DFID, may lower its aspirations and allow Africa to slip down the international agenda. It could become discouraged by its inability to persuade Western governments to end unfair trading practices or to reform international organizations. It could, equally, be disappointed by Africa's (widely predicted) failure to meet international targets on poverty reduction and by the reluctance of African 
presidents to condemn the actions of fellow leaders like Robert Mugabe. It could also be distracted by issues like Britain's integration into the European single market and the US-led war on terror.

Faced with such distractions, a future Labour government may well decide - particularly if it has a narrow parliamentary majority and the UK economy is in recession - to review the merits of its third-way policy towards Africa. It will, however, more than likely, choose to continue charting a course between the Scylla of realpolitik and the Charybdis of moralpolitik.

\section{References}

Blair, T. (1999a) 'The Doctrine of International Community', speech to the Economic Club of Chicago, 22 April 1999.

- (1999b) 'Shaping a Pivotal Role for Britain in the World', speech to Lord Mayor's Banquet, London, 22 November 1999. (2001) Speech to Labour Party Conference, Brighton, 2 October 2001.

_ (2002) Speech to Nigerian National Assembly, Abuja, 7 February 2002.

Burnell, P. (1993) 'Good Government and Foreign Aid', Working Paper 115, Warwick University, Warwick.

Chalker, L. (1991) 'Good Government and the Aid Programme', speech to the Royal Institute of International Affairs, London, 25 June 1991.

(1997) 'The ODA's Private Sector Initiative', speech to the CBI (Confederation of British Industries), London, 29 January 1997.

Chossudovsky, M. (1997) The Globalisation of Poverty: Impacts of IMF and World Bank Reforms, London: Zed Books.

Clapham, C. (1996) Africa and the International System, Cambridge: Cambridge University Press.

Cook, R. (1997) 'British Foreign Policy', speech at the launch of the Foreign Office Mission Statement, Locarno Suite, FCO (Foreign and Commonwealth Office), London, 12 May 1997.

- (2000) 'Foreign Policy and the National Interest', speech to the Royal Institute of International Affairs, London, 28 January 2000.

Cornia, G. A. et al. (1987) Adjustment with a Human Face, Oxford: Clarendon Press.

Crawford, G. (2001) Foreign Aid and Political Reform: A Comparative Analysis of Democracy Assistance and Political Conditionality, London: Palgrave.

Cumming, G. D. (2001) Aid to Africa: French and British Aid Policies from the Cold War to the New Millennium, Aldershot: Ashgate.

DAC/Development Assistance Committee (1997, 2001) Development Cooperation Review Series: United Kingdom, Paris: OECD.

- (2003) Development Cooperation Report 2002, Paris: OECD.

Department for International Development (1997) Eliminating World Poverty: a Challenge for the 21st Century, White Paper, London: DFID.

- (2000) Eliminating World Poverty: Making Globalisation Work for the Poor, White Paper, London: DFID.

- (2001) Background Brief, February, London: DFID.

- (2002) Departmental Report 2002, London: DFID.

- (2003a) Africa Action Plan: UK Progress Report, London: DFID. 


\section{Gordon D. Cumming}

- (2003b) Departmental Report 2003, London: DFID

Dunne, T. and Wheeler, N. J. (2001) 'The Blair Doctrine', in R. Little and M. WickhamJones (eds), New Labour's Foreign Policy, Manchester: Manchester University Press, 61-76.

Foreign Affairs Committee (1999) Second Report: Sierra Leone, 9 February 1999, London: House of Commons.

Hain, P. (1999) 'Africa: Backing Success', speech at the Challenges for Governance in Africa Conference, Wilton Park, 13 September 1999.

Harman, D. (2002) 'Somalis Wary of Growing US Scrutiny', Christian Science Monitor, 8 January 2002.

Healey, J. (1997) 'UK Aid Management', in A. Cox et al. (eds), How European Aid Works, London: ODI, 210-22.

Heath, T. and Hill, R. (2002) Asylum Statistics, United Kingdom 2001. Online. Available HTTP: <http://www.homeoffice.gov.uk>.

Hill, C. (2001) 'Foreign Policy', in A. Seldon (ed.), The Blair Effect, London: Little Brown.

Hurd, D. (1990) 'Prospects of Africa in the 1990s', speech to the Overseas Development Institute, London: FCO, 6 June 1990.

(1995) Transcript of speech, 'Aid Tasks for the Future', London: FCO.

KirkGreene, A. (2000) 'Accredited to Africa: British Diplomatic Representation and African Experience', Diplomacy and Statecraft, 11 (1), 79-128.

Labour Party (1997) A Fresh Start, London: Labour Party.

- (2001) Ambitions for Britain, London: Labour Party.

Lancaster, C. (1999) Aid to Africa: So Much to Do, Chicago: Chicago University Press.

Legum, C. (1999) 'British Policy in Africa', in C. Legum (ed.), Africa Contemporary Record 1996-98, New York: Africana Publishing.

Lloyd, A. (1999) Speech to the Africa Day Conference, Lancaster House, London, 26 May 1999.

MacShane, D. (2002) Speech to Chatham House, London, 13 February 2002.

McKinlay, R. and Little, R. (1978) 'A Foreign Policy Model of the Distribution of British Bilateral Aid 1960-70', British Journal of Political Science, 8 (3), 313-32.

Melvern, L. R. (2000) A People Betrayed, London: Zed Books.

Morrissey, O. et al. (1992) British Aid and International Trade: Aid Policy-Making 1979-1989, Buckingham: Open University Press.

Mosley, P. (1991) 'Britain, the World Bank and Structural Adjustment', in A. Bose and P. Burnell (eds), Britain's Overseas Aid, Manchester: Manchester University Press, 74-85.

ODA/Overseas Development Administration (1995) Progress Report on ODA's Policy Objectives 1992-94, London: ODA.

Rifkind, M. (1996) Speech to the Royal Institute of International Affairs, London, 28 November 1996.

Robertson, G. (1997) On the Record. Online. Available HTTP: <http://www.bbc. co.uk> (accessed 26 October 1997).

Rouvez, A. (1994) Disconsolate Empires, New York: University of America Press.

Short, C. (1997a) Foreword to DFID, Eliminating World Poverty, London: DFID.

_ (1997b) 'Eliminating Poverty', speech to Commonwealth Institute, London, 26 June 1997. 
(1997c) 'The Role and Functions of the DFID', speech to School of Oriental and African Studies, London, 28 May 1997.

Taylor, I. and Williams, P. (2002) 'The Limits of Engagement: British Foreign Policy and the Crisis in Zimbabwe', International Affairs, 78 (3), 547-65.

Vachers (2002) Vachers Parliamentary Companion, London: Dodd.

Vereker, J. (1998) 'International Development: Beyond the White Paper', speech to the ODI (Overseas Development Institute), London, 21 January 1998.

\section{Newspapers}

Daily Telegraph, London.

Guardian, London.

Independent, London.

Scotland on Sunday, Edinburgh. 


\title{
5 United States \\ The process of decision-making on Africa*
}

\author{
Donald Rothchild and \\ Nikolas Emmanuel
}

\section{Introduction}

The US combines enormous power with limited ability to influence the preferences of African leaders. As the sole remaining superpower, it has vast military strength and logistical capacity to project its power throughout the globe. At the same time, its influence is limited by the relative autonomy of the African state and the narrow nature of US strategic and economic interests. The consequence is a low-profile approach to African issues with a short-term escalation in concern at such times as leaders or the public display unease over particular issues.

In short, US interests in African affairs are limited but nevertheless real. Both because it is a status quo power and because it is the only superpower left, US administrations are inclined to take the necessary measures to maintain international stability, including stability in Africa. It is the argument of this chapter that the interest in promoting and maintaining stability in Africa too has been and continues to be the main determinant of US Africa policy. Because of this fundamental interest, no US administration can afford to disengage from conflict management, the enhancement of trade relations or the prevention of disease in Africa. Therefore, it is no coincidence that recent administrations have stressed such core objectives as promoting regional stability and conflict management, encouraging Africa's economic development and international trade, strengthening state structures to prevent terrorism and criminal activities, and furthering democracy and human rights (Rothchild 2002: 216).

These interests are clearly interrelated. Sustained stability, for example, is intimately linked with economic development, since poverty and lack of economic opportunity are recognized as major causes of ethnic and regional tensions and violence. American policy-makers perceive terrorism in Africa to be a direct threat to their strategic interests in recent years. They also

\footnotetext{
* We wish to express our appreciation to Steven Browning, Letitia Lawson, Miroslav Nincic, Edith Rothchild, and Barry Schutz for their comments.
} 
look with concern at evidence of political instability and civil war in West Africa (particularly in Liberia and Sierra Leone), the Horn of Africa, and the Democratic Republic of Congo. It is because of the perceived interconnections of state weakness, lack of economic opportunity, and religious extremism in such countries as Somalia and Sudan that US officials regard these states as especially threatening to regional stability, and therefore US interests, in the current period.

\section{Policy phases}

Although the US did not have any recognized colonial relationships in Africa, it nonetheless maintained what amounted to virtual colonialism in its relationship with Liberia and, in particular, with the Americo-Liberian settler community. The government supported the repatriation of the AmericoLiberians to Liberia in the early 1800s under the auspices of the American Colonization Society. These 'settlers' proceeded to establish what George Kieh (2003: 309) describes as a hegemonic 'caste' relationship with the indigenous groups in the country. Elsewhere, during colonial times relations with Africa were largely informal, with US diplomats, commercial interests and missionary organisations forging a variety of commercial and cultural ties with local elites.

The government's attention to African issues increased during the post World War II period, reaching high points during the Cold War, the struggle against South Africa's apartheid system, and the Somali intervention. We see four major historical periods in US-African relations: minimal engagement (1946-76); accommodation with African aspirations (1976-80); strategic globalism (1981-9); and hegemonic power combined with cautious engagement (1990 to the present). The styles of different administrations diverged, sometimes quite noticeably. However, with the exceptions of US initiatives during the Cold War, the enactment of the 1986 Comprehensive AntiApartheid Act in 1986, the mediation of the Angola-Namibia accords in 1988, and the humanitarian intervention in Somalia in 1992, the intrusions were generally hesitant and circumscribed.

\section{Minimal engagement 1946-76}

In the initial 30-year period after decolonization, US policy-makers were notably restrained in their relations with the newly independent states of Africa, urging them to avoid any disruptions in their relations with the former colonial powers and to maintain the international state system intact. Not viewing itself as a colonial power, US administrations sought to work through Western European countries as far as possible. The Kennedy administration (1961-3), breaking with the earlier tendency toward isolation from African affairs, made a conscious effort to accept and work actively with African nationalist leaders, including radical leaders in Mali and Guinea. However, 


\section{Donald Rothchild and Nikolas Emmanuel}

this concern and willingness to deal with radical as well as moderate African leaders soon lost much of its appeal as successor administrations became absorbed in the Vietnam War. The US tendency to neglect of African aspirations for political and social change and economic development, and to identify with conservative leaders in Africa, became particularly evident with the early Nixon administration (1969-74). Nixon tilted noticeably to the right on policy issues affecting Southern African race relations. Not only did he allow a partial relaxation of the arms embargo against the Portuguese and South Africans, but US voting patterns at the UN displayed little sensitivity on issues of apartheid or self-determination (Rothchild 1979: 307-9).

\section{Accommodation with African aspirations}

In 1976, the minimal-engagement approach shifted dramatically toward an accommodation with African aspirations. The US Congress, perceiving the covert backing of guerrilla movements in Angola to be a losing cause, refused to support Secretary of State Henry Kissinger's call for a confrontation with the Soviet-Cuban backed MPLA forces. Senate liberals called on Kissinger to retreat from sponsoring military resistance to the Angolan regime and urged instead a policy of cooperation with the forces of change in that country. With the passage of the 1975 Tunney Amendment (denying funds for covert action in support of insurgent armies in Angola), Kissinger accepted the necessity of shifting his policy stance. In a major policy address in April 1976 in Lusaka, Zambia, he announced a ten-point programme aimed at bringing about a peaceful conclusion of the conflict in Southern Rhodesia (Zimbabwe). In addition to calling for rapid movement toward majority rule, Kissinger warned the Rhodesian government not to expect US diplomatic or military support and promised to provide financial backing for neighbouring African states suffering from the closure of their borders with Southern Rhodesia. He also spoke of the need to facilitate negotiations on majority rule in Namibia and quiet, behind-the-scenes pressures to end apartheid and racial discrimination in South Africa.

In essence, the Kissinger strategy of accommodating African aspirations was continued and strengthened under its successor administration (1977-80) led by President Jimmy Carter. However, these administrations differed fundamentally on the extent they were prepared to intervene in independent South Africa. Whereas Kissinger accepted the legitimacy of the South African government and sought to use its government to press Rhodesian authorities for change (Rothchild 1997: 157-61), the liberal internationalist Carter administration shunned a dual strategy approach and applied a single regional solution to white racism across the sub-region. Carter's commitment to majority rule throughout the sub-region may well have entailed a longer struggle; in the end, however, its accommodationist stance proved prudent, for it advanced the process of majority self-determination - the only principle the African peoples would have found acceptable in the long run. 


\section{Strategic globalism 1981-9}

The Reagan administration (1981-8) shifted the emphasis to an allencompassing competition with Soviet interests in Africa, i.e. the phase of strategic globalism. Although the lines of this approach had begun to take shape in the late Carter period, it was now pursued with a single-minded determination not witnessed before. Arguing that liberal internationalism failed to deal effectively with the threat posed by Soviet power, the Reagan team stated firmly that it would not stand on the sidelines while Soviet and Cuban actions sought to 'fuel the fires of instability' (Rothchild and Ravenhill 1983: 349). Even if the Soviet Union did not instigate the African conflicts, the new administration feared that it would exploit them to achieve its regional goals. Reagan's globalist orientation, which perceived an organized Soviet threat as the source of African difficulties, largely restricted the African agenda to East-West issues. As part of this worldview, it distinguished basically between African friends (such as Morocco and Kenya) and enemies (such as Libya and Angola), and it rewarded the former while punishing the latter. This brought the US in close proximity at times with regimes disliked by their people for racist tendencies (South Africa) or for their repressive and corrupt practices (Zaïre).

As the Bush team became convinced that Soviet President Mikhail Gorbachev was sincere in his desire to cooperate with the West on matters relating to regional conflict and arms control, the intensity of superpower rivalry waned and a new phase in US policy on Africa materialized, i.e. hegemonic power combined with cautious engagement.

\section{Cautious engagement 1990 to the present}

Clinton's Africa policy (1993-2000) differed markedly in style from that of his predecessor, being more inclined toward multilateralism, the enlargement of democracy and human rights as well as the objectives of peacekeeping, debt relief and disease prevention. Its outcomes, however, were largely in line with the extended trajectory on minimal engagement with African affairs and the emphasis upon ensuring political stability on the continent. At the time of the 1992 elections, Clinton advocated active US leadership on various African questions. As the Somali initiative turned deadly and 18 American servicemen were killed in an engagement with militiamen in central Mogadishu in October 1993, however, the President came under heavy Congressional pressure to reduce the US commitment to the peacekeeping effort in Somalia. In an attempt to avoid a headlong collision with Congress, Clinton acted prudently and announced his intention to withdraw US forces by March 1994.

The Somali disengagement helped establish a trend toward reduced military involvement in African conflicts. It was followed in May 1994 by the publication of Presidential Decision Directive (PDD) 25. This major strategy statement, long in the works, called for a more selective and more effective 


\section{Donald Rothchild and Nikolas Emmanuel}

involvement by the US and the UN in multilateral peacekeeping. This directive signalled a return to a longstanding inclination to adopt a lowprofile stance on dealing with African conflicts. The effects could be seen almost immediately, as the US stayed on the sidelines in 1994 when Rwanda's genocidal fury burst out in the open. The inclination not to engage also became evident in other highly destructive conflicts - Burundi, Sudan, Liberia, and the DRC. The sole remaining superpower chose to be inactive just at the point that many weak African states found themselves dangerously challenged.

Clinton's successor, George W. Bush, came to office proclaiming his distaste for a proactive commitment to multilateral peacekeeping, democracy promotion, and a generous economic aid policy. African issues were placed at a relatively low point in terms of Bush administration foreign policy priorities. 'While Africa may be important', he declared during his campaign for the presidency, 'it doesn't fit into the national strategic interests' of the USA (Rothchild 2002: 238). With no threat to US strategic interests apparent on the African scene, this 'realist' saw no challenge to the maintenance of US global hegemony in this area in the years ahead. Consequently, the George W. Bush administration downplayed African issues in its early years and generally resisted calls intended to draw it into a lead role in dealing with the festering conflicts in Liberia, Sierra Leone, Burundi, or the DRC. An exception to this tendency on distancing itself from African involvements was its intercession in the brutal internal war in the Sudan.

\section{Post September 11}

African issues gained in significance for the Bush administration as terrorists launched an attack on the World Trade Center on September 11, 2001. From this point forward, Africa became part of the US global effort to promote its status quo agenda by waging war on international terrorist activities wherever they appeared. Moreover, the younger Bush, possibly searching for demonstrations of international concern in Africa during an otherwise gloomy period, focused on two potentially significant policy questions - the African Growth and Opportunity Act (AGOA), which was initially conceived and guided through Congress by the Clinton administration, and a far-reaching commitment to deal with the pandemic of HIV/Aids. Although these policy issues are important in themselves, it is nonetheless necessary to put them in context for they in no way undercut the main Bush identification with political realism and involve little in the way of financial sacrifice. In essence, then, the Bush administration was giving its theme of 'compassionate conservatism' an international face with its application to Africa.

In line with this worldview, it is important to note two other factors: the link between state failure and terrorism, and the focus on expanding Africa's oil production. Weak and failed states have served as the theatres for some of the most intense wars in recent years. Millions of refugees, fleeing combatants and traffickers of all sorts quickly become regular features in and around failed 
states. This creates an environment favourable for the development of wider regional conflicts, with the potential for significant economic and security costs to neighbouring states. The only major initiative to deal with the perceived threat of weak states begun under Clinton, and continued to this day, was an effort to develop early-warning mechanisms to detect state failure, along with preventative measures that could be used to bolster such at-risk countries.

The Bush administration continued the Clinton line and, after the September 11 attack, emphasized the possibility that weak states could pose a risk to US national security, creating opportunities for terrorist strikes. Accordingly, Bush's 2002 National Security Strategy (NSS) paper stated that 'America is now threatened less by conquering states than we are by failing ones'. Noting that poverty does not make people into terrorists, Bush commented that when poverty was linked to weak institutions and corrupt behaviour, it could 'make weak states vulnerable to terrorist networks and drug cartels within their borders'. These statements highlighted the Bush administration's uncertainties about the effects of weak states on the international environment; however, they gave no indication as to which failed states were likely to become national security risks.

In an effort to reduce uncertainty over supplies of oil, the Bush administration has made Africa central in its efforts to reduce dependence on petroleum imports from the Middle East. Thus, Assistant Secretary of State for African Affairs Walter Kansteiner stated that, 'African oil is of national strategic interest to us, and it will increase and become more important as we go forward' (IASPS/AOPIG 2002). The National Energy Policy (NEP) put together by Vice President Dick Cheney in May 2001 underscored the point that 'Africa is expected to be one of the fastest-growing sources of oil and gas for the American market'. Indeed, forecasts by the National Intelligence Council estimate that the US could be importing as much as 25 per cent of its oil from Africa by 2015, from 12 per cent in 2002.

Just how significant is Africa's potential oil contribution to US national needs likely to be? Africa has the third largest petroleum reserves, after the Middle East and Latin America, estimated at 80 bn barrels or 8 per cent of the world's crude (UNCTAD 2001). When compared to the Middle East's 690 bn barrels of reserves, Africa is a minor player. Nonetheless, several African countries hold significant potential for expanded production. US companies are playing a leading role in this, being expected to invest some $\$ 10 \mathrm{bn}$ annually in the years to come. Nigeria and Angola, Africa's largest producers and the fifth and ninth most important crude exporters to the US in 2002 $(589,000$ and $321,000 \mathrm{~b} / \mathrm{d}$ respectively), are both expected to double daily total output by 2020 (USDOE/EIA 2002). Promising new finds in the waters off Equatorial Guinea and Sao Tomé and Príncipe as well as in Chad are likely to make them major regional producers in the years to come. To support this expansion, the US can be expected to increase its diplomatic presence in these countries and to raise its economic and military assistance to them in the years ahead. 


\section{Policy-making}

The process of US policy-making toward Africa involves four distinct patterns. These patterns take place within the decision-making apparatus of the executive branch and deal with most African issues. In addition, it is important to note that actors outside the executive branch, primarily involving Congress and various lobbying groups, play an important role in influencing US policy on Africa. In this section we will outline the formal institutional structures, the four patterns that emerge from the policy-making process, and the outside influences on executive decision-making.

\section{Pattern 1: Internal agency decisions on routine situations}

\section{Institutional structure}

African affairs receive little attention at the most senior policymaking levels in Washington, DC. Lower-level officials, however, from a wide range of executive departments and agencies deal with these issues on a daily basis. The 1992 National Security Directive (NSD No.75) on 'American Policy Towards Sub-Saharan Africa in the 1990s' lists 11 executive agencies and departments involved in articulating US-African policy. Five of these bodies, the Departments of State, Defense, and Commerce, USAID, and the CIA, are responsible for most decisions, either independently or within the interagency process.

\section{Decision-making patterns}

The main focal point of US policy on Africa is the State Department's Bureau of African Affairs (also referred to as the Africa Bureau), under the supervision of the Assistant Secretary of State for African Affairs. Since the Africa Bureau does not get extensive direction from the Secretary of State or the White House, it often finds itself largely on its own, free to pursue policies that involve quiet diplomacy and low-level negotiations. In Liberia, for example, the Africa Bureau decided early on to pursue its own conflict-resolution strategy without requesting approval from its superiors in the bureaucracy (Cohen 2000: 218). The absence of White House or Secretary of State leadership was something of a liberating element, for it enabled former Assistant Secretary of State Herman Cohen to engage in a policy initiative on Liberia that his counterparts in Europe and the Middle East could only contemplate. Other examples of Africa Bureau initiatives, such as Mozambique (1990-2) and Rwanda (1990-4), are illustrative of cases where the Africa Bureau sent its own envoys to work with American diplomats in the field to facilitate negotiations between the warring factions (Cohen 2000: 169-72, 189-90). The Africa Bureau is able to maintain freedom of action as long as it does not step beyond this pattern of limited commitment. In circumstances that potentially 
involve deeper US involvement, the policy-making process frequently requires the bringing together of Africa specialists from across executive agencies.

\section{Pattern 2: Low-level crisis requiring interagency coordination}

\section{Institutional structure}

The National Security Council (NSC) interagency system plays a central role when complex situations necessitate a coordinated response from several bureaucracies. This process brings together policy-makers and structures to facilitate coherent responses to crucial foreign policy issues. These options may then be brought to the attention of the president, who presides at the summit of the decision-making pyramid. Interestingly, although each administration makes adjustments in the NSC interagency structure, the overall framework has remained basically intact over recent administrations. When an issue arises and requires a coordinated response, the formal interagency policymaking process begins in the Policy Coordination Committee (PCC).

\section{Decision-making pattern}

The PCC serves two main functions. First, the PCC process co-opts actors from major departments and attempts to build a formal interagency consensus on policy matters. In most cases the Africa PCC members develop a consensus, however, because they have a bureaucratic interest in promoting activities in their region. Second, the PCC represents a means of pooling resources. Although the State Department is often the lead actor in US-Africa relations, it is relatively poor in resources when compared with the Department of Defense. Resource-pooling enlarges its access to funding, but not without creating some friction at times between the State and Defense Departments (Kansteiner 1996).

Once the various members are in agreement, the policy-making process moves forward with the drafting of a short national security guidance paper reviewing the situation and outlining several alternative policy options (Kanter 1996). This is then submitted to the next most senior level - the Deputies Committee (DC). The DC, after reviewing the options, can assign tasks to the PCC, reject the proposed policy, or manage the policy making process itself.

\section{Pattern 3: Major crisis situation requiring interagency coordination}

\section{Institutional structure}

The DC represents an intermediate level in the NSC system. It is chaired by the Deputy National Security Advisor and is composed of deputy and undersecretary-level officials. Playing a crucial role in the decision-making process, 


\section{Donald Rothchild and Nikolas Emmanuel}

the DC orchestrates interagency relations and supervises policy-making. Furthermore, the DC identifies unresolved policy issues that are to be passed up to the more senior Principals Committee and also delegates tasks to the lower-level PCCs.

\section{Decision-making pattern}

Concerning US-Africa relations, the DC acts as gate-keeper, promoting the status quo and blocking costly actions initiated by lower-level officials.

\section{Pattern 4: Major crisis involving senior officials}

\section{Institutional structure}

The Principals Committee (PC) is the most senior interagency forum, bringing together officials at the Secretary and Director levels to consider policy options developed by the PCC or DC and to advise the President on appropriate actions. The PC's broad policy outlines are framed in national security memoranda, currently called National Security Presidential Decrees (known in the Clinton years as PDDs). The PC is chaired by the president in the current Bush administration and includes NSC staff members, the heads of all major departments and agencies, and the vice president. This has not always been the case. Under Bill Clinton, for example, the President and the Vice President were not required to attend PC meetings, which were chaired by the National Security Advisor.

\section{Decision-making pattern}

Because African issues usually are accorded a relatively low priority by the president and his senior officials, the PC deals only with the most extreme African crisis situations. 'The triggering mechanism for sustained presidential attention to African issues', notes Peter Schraeder (1994: 26-7), 'is usually the occurrence of some type of intense politico-military conflict'. Somalia did work its way up the decision-making line to become a rare case of PC concern in the post Cold War period (Kansteiner 1996). At the outset, the State Department's Africa Bureau dealt with the Somali challenge on its own. It took the policy as far as it could before handing responsibility for Somalia off to the Africa PCC. This deadlock ended suddenly in mid August when, without consulting the Africa PCC, the White House announced an emergency humanitarian airlift in response to widespread public concern over the country's massive starvation (Cohen 2000: 209). The DC met on 21 November 1992 and decided that US forces should be deployed to improve security and facilitate the humanitarian effort (Western 2002: 112). This came after the Joint Chiefs of Staff and the Department of Defense dropped their hesitations about committing troops. Following this announcement, President Bush 
(senior) called for a meeting of the Principals Committee to lay out the guidelines for a humanitarian-military operation in Somalia (Kansteiner 1996).

\section{Congressional and special interest influences}

Beyond the executive, Congress - i.e. the House of Representatives and the Senate - and various lobbying groups represent two important influences on US policy-making toward Africa. Although Congress often lacks a formal role in executive decision-making, it can play a crucial part in formulating and implementing US policies on Africa. Congress can, as in such cases as the 1986 Comprehensive Anti-Apartheid Act or the recent Sudan Act, use its legislative powers to influence policy, regardless at times of executive preferences. However, these are relatively unusual events. More commonly, Congress exerts leverage through its capacity to grant or withhold funding for specific programmes. In addition, its House and Senate Subcommittees on Africa can use their oversight power to hold hearings on US policy. These hearings and debates can have enormous impact on national security and foreign policy, as in the case of policies on South African sanctions or on the decision to withdraw US troops from Somalia (Kanter 1996). The threats of withholding funds or holding hearings has a profound influence on the executive branch, for it promotes a self-imposed timidity on policy-makers as they determine how far they can push an issue without arousing Congressional attention, or even its ire.

Lobbyists representing private business interests, foundations, academia, professional associations, and voluntary groups concerned with Africa can also influence policy-making in significant ways. For one thing, lobbyists can try to change the preferences of congressmen or senators, as in the case of the anti-apartheid movement or the organized public letter-writing campaigns used by TransAfrica and UNICEF to pressure key members of Congress in 1992 to initiate a response to the Somali crisis (Cohen 2000: 208-9). The Corporate Council on Africa exerts broad influence on US policy-makers regarding decisions affecting commercial and business interests. Lobbyists may also try to influence both the executive and legislative branches simultaneously. For example, powerful oil industry groups exert enormous influence on the White House and Congress, as these lobbyists seek to advance corporate interests on oil production in Africa and US corporate involvement in it. Moreover, Ethiopian diaspora groups, realising that most decisions on US policy towards Africa take place in the State Department's Africa Bureau, focused much of their lobbying efforts in mid 1989 on the appropriate government officials (Cohen 2000: 23).

\section{Responding to Africa's challenges}

Despite its narrow interests in Africa, post-Cold War administrations have shown a continuing (if limited) concern with four issues-areas: conflict 


\section{Donald Rothchild and Nikolas Emmanuel}

management; democracy and human rights; increased trade and economic development; and halting the HIV/Aids pandemic. US policy-makers continue to rank Africa as a relatively low priority region, but since Clinton's re-engagement with African affairs in 1998, policy-makers have shown increasing interest in reducing tariff barriers on textile and other imports and increasing assistance to combat the scourge of HIV/Aids. It is important to ask in this final substantive section whether this is likely to lead to a higher US profile on African-related issues.

\section{Conflict management}

US policy-makers have been extremely cautious about high-profile interventions in Africa since the Somali disengagement. After long resisting the appeals of foreign governments and the UN to send combat forces to African conflict areas such as Liberia, Sierra Leone, Côte d'Ivoire, Burundi, and the DRC, the US began considering the dispatch of a limited number of peacekeepers to oversee the cease-fire in Liberia in July 2003. US leaders also resisted supplying major weaponry or financial support to multilateral peacekeeping operations. The US government did provide over $\$ 95 \mathrm{~m}$ in financial assistance to help the ECOWAS Cease-fire Monitoring Group (ECOMOG) peacekeeping operation in Liberia and Sierra Leone (Rotberg et al. 2000: 144) and in 2003 did contribute $\$ 1.5 \mathrm{~m}$ to the ECOMOG peacekeeping effort in the Côte d'Ivoire (Washington File, 14 February 2003). But these outlays were relatively small.

US policy-makers in the current period are inclined to pursue limited national interests by means other than formal military action. A force of 1,800 troops is stationed in Djibouti engaging in counter-terrorist activities on the Horn, and the Pentagon is seeking access to other bases in friendly countries. Moreover, the Defense Department plans to expand existing military training programmes and to broaden intelligence operations. However, the US has been cautious about other commitments, such as peacekeeping in the DRC, where US interests are less directly affected. Three main reasons account for this reticence. First, US interests are perceived as minimal in a number of conflict areas. Second, budgets are stretched, particularly as the US expands its military and intelligence capacities to deal with terrorist threats around the world. Third, as Africa's state structures weaken and wars are primarily internal and less formal and organized, it becomes more difficult for Western armies to intervene in an effective manner. As a consequence, US leaders (and the public - see Rothchild and Emmanuel 2003) tend to show a strong preference for diplomatic initiatives, and when there appears to be no alternative to becoming involved, they incline toward indirect rather than direct military action (Jentleson 1992: 52).

At times, where the targeted actors paid no heed to strong statements, however, the US government increased the pressure by closing embassies, denying legitimacy to governments, directing economic assistance to civil 
society organizations and away from the government, and invoking sanctions. The US, seeking to halt Liberia's role in the funding of insurgent forces in Sierra Leone, supported UN sanctions against Liberia's political and business elite with an embargo on Liberia's export of diamonds. The UN Security Council also prohibited Liberia's purchase of military equipment and placed a travel ban on Liberia's senior officials. And in Zimbabwe, President George W. Bush, accusing President Robert Mugabe of undermining democracy, signed an executive order in March 2003 imposing economic sanctions on the chief executive and his immediate entourage, freezing their assets, and barring Americans from having any financial dealings with them (BBC News, 7 March 2003). US officials, fearing regional destabilization, strongly condemned the 'upsurge of official violence' against domestic opponents of the regime. They demanded that the Mugabe government 'act to identify and bring to justice the perpetrators of these serious and widespread human rights abuses' (Washington File, 24 March 2003).

US involvement in the Sudanese peace process during the first G. W. Bush administration stands out as its most active engagement in African conflict management. US diplomats, plunging themselves into this protracted civil war, backed the IGAD efforts and engaged in mediation in an effort to resolve the bitter conflict between the government and the southern-based SPLA. Not only did the Congress pass the Sudan Peace Act threatening diplomatic and economic sanctions against the Sudanese government if the Bush administration found that it was not engaged in good-faith negotiations, but US diplomats also mediated an internationally monitored cease-fire arrangement in the Nuba Mountains in 2002. They also helped facilitate a framework for negotiating the issues of religion and self-determination under the Machakos Peace Protocol (International Crisis Group, September 2002). The Bush administration's mediatory initiative stands out for its relatively high profile nature on specific issues; yet even this action hardly contradicts the general proposition on the US proclivity for low-cost, low-risk engagements on African conflict questions.

\section{Democracy promotion}

With the end of the Cold War, various US administrations emphasized the promotion of democracy in Africa and elsewhere. The high value they placed on democracy promotion was, as G. John Ikenberry (2000: 104) noted, 'part of a larger liberal view about the sources of a stable, legitimate, secure, and remunerative international order'. Democracy promotion is a broad term that includes such activities as assisting the African countries to establish their electoral activities, draft laws and constitutions, reform their police services, and train and fund civil society organizations. The furthering of democratic institutions is intended to promote America's political purposes by encouraging the conditions for a more stable world order. As a by-product of this political stability, it is expected to lead to more productive 


\section{Donald Rothchild and Nikolas Emmanuel}

societies that would become better partners for US trade and investment activities.

The effort to encourage the development of democratic regimes in Africa reached a high point during the Clinton years as the theme of 'enlarging democracy' became a core administration foreign policy principle. As his National Security Adviser, Anthony Lake, declared in an important address in 1993 at Johns Hopkins University: 'The successor to a doctrine of containment must be a strategy of enlargement - enlargement of the world's free community of market democracies' (Lake 1993). Democracy promotion provided US foreign policy with a vision - a sense of direction that linked American political values with an agenda for action. Moreover, these values were generally appealing to the large majority of informed Africans. Having long suffered under the arbitrariness and restraints of authoritarian governments, civil societies mobilized in many countries to demand the multiparty elections and transition to democracy that the Clinton policy-makers were advocating.

Although championing democratic transitions in policy declarations, it has proved difficult at times to transform principle into practice. The number of African states classified as 'free' by Freedom House did jump from three in 1990, eight in 1999, to 11 in 2003 (www.freedom.org); nevertheless some American analysts, such as Marina Ottaway (2003), described these findings as 'superficially rosy'. American officials, despite their strong support for democracy promotion in principle, were generally reluctant to link the threat of an aid cut-off to reform of the political process, although where an administration was serious about conditionality (in Kenya and Malawi), movement toward multiparty elections did become apparent. In addition, USAID gave limited financial backing to democracy promotion. Under Clinton, data for 1997-2000 indicates that US support for democratization in Africa fell to 5.4 per cent $(\$ 249.477 \mathrm{~m})$ out of a total USAID development assistance allocation of $\$ 4,514.3 \mathrm{~m}$ (Rothchild 2002: 224). Under the second Bush administration, the trajectory of support for democracy promotion was in a downward direction. In 2003, for example, Democracy and Governance represented only 2.94 per cent of total US aid to Africa. If one includes the allocations from the Office of Transition Initiatives, this figure rises to 4.1 per cent. In addition, the 2003 allocations are increasingly concentrated on a few countries. 16 countries in sub-Saharan Africa received aid under the Democracy and Governance Programme, with one-half of this assistance earmarked for the countries of Nigeria, South Africa and Mali, which were already committed to reform (USAID 2003).

\section{African Growth and Opportunity Act}

The African Growth and Opportunity Act (AGOA), conceived by the Clinton administration and passed by Congress in 2000, is an example of a compassionate action that addresses realist concerns. Combining the logic of 'trade, not aid', the Clinton team and subsequently the Bush administration 
envisioned AGOA both as a means of furthering African development through export-lead growth and as an alternative to traditional economic assistance. Under this legislation, 38 African countries that meet a number of conditions can export a wide variety of goods to the USA duty-free and tariff-free until 2008. The government hopes that this preferential access to the US domestic market will spur exports, create jobs and lead to Africa's economic development.

Unfortunately, AGOA's initial results have been less than impressive, leaving the overall structure of US-Africa trade relations essentially unchanged. In fact, in recent years African exports to the US declined by over 23 per cent - from $\$ 18.3$ bn in 2000 to $\$ 14$ bn in 2002 (USTR 2003a). However, AGOA imports have increased by 9 per cent, from $\$ 8.2$ bn in 2001 to $\$ 9$ bn in 2002. This is attributable primarily to the expansion of the list of goods receiving preferential treatment. Trade was concentrated on three African exporters (Nigeria, South Africa and Gabon), which accounted for 90 per cent of AGOA imports (USTR 2003b).

While much of the rhetoric surrounding AGOA focused on how textile and clothing exports to the US would lead to a renaissance in local economic development, the outcome has been far from inspiring. Certainly, there has been some increase in apparel exports to the US, especially from Lesotho, Swaziland and Madagascar. However, in 2002 this sector only represented 9 per cent $(\$ 800 \mathrm{~m}$ ) of all AGOA goods coming to the US (USTR 2003a). The export of apparel was dwarfed by crude oil, which under AGOA added up to 75 per cent ( $\$ 6.8 \mathrm{bn}$ ) of total African imports under the programme (USTR 2003). The third largest sector of AGOA trade, transportation $(\$ 544 \mathrm{~m})$, is dominated by South African automobile parts makers, such as BMWSouth Africa (USTR 2003b). Although African agriculture has enormous immediate export potential (e.g. cacao, coffee, cashews, avocados, etc.), this economic sector only represents two per cent $(\$ 212 \mathrm{~m})$ of all AGOA trade (USTR 2003b). Hundreds of the agricultural products are in principle covered under the AGOA agreement. Yet in practice they are barred by the stringent laws imposed by the US Department of Agriculture (USDA) on plant and animal imports. The process of admitting goods into any US port can prove very time-consuming, resulting in the loss of perishable goods.

Beyond increasing trade, AGOA is also an instrument that provides Washington with political leverage in Africa. The AGOA initiative makes preferential access conditional on good government and respect for human rights. Paradoxically, however, a good number of the countries eligible for preferential treatment under this legislation have very questionable records on these matters. In 2003, according to Freedom House, only 11 of the 38 countries in AGOA are democratic, 19 are in transition, and eight are authoritarian (Freedom House 2003). Furthermore, every year the list of eligible countries is reviewed and countries are identified that have not made continuing progress toward market-based economies, the rule of law, free trade, economic policies reducing poverty, and protection of workers' rights. 


\section{Donald Rothchild and Nikolas Emmanuel}

Accordingly, in early 2003, the Department of State warned both Swaziland and Eritrea that problematic governance issues might threaten their eligibility under the AGOA programme. State Department officials then gave these countries six months to improve their performance or be dropped from the list of AGOA-eligible states.

\section{US-Africa relations and HIVIAids}

The recent concern over the spread of HIV/Aids represents a significant shift in US thinking on an Africa-related issue. Never before has a disease received so much official attention in Washington. Aids, since its discovery in 1981, has taken an enormous toll in sub-Saharan Africa. The statistics are ghastly. At the end of 2002, an estimated $29.4 \mathrm{~m}$ Africans were living with HIV/Aids, 70 per cent of the $42 \mathrm{~m}$ people infected with the disease worldwide. Each day almost 8,500 Africans die from the virus and over 14,000 Africans contract it. In the absence of massively expanded prevention, treatment and care efforts, the Aids death toll on the continent is expected to continue rising, and be responsible for the deaths of $55 \mathrm{~m}$ Africans in the next two decades (NIC 2000b). For the first time in US-Africa relations, the continent, at the epicentre of this pandemic, has become perceived as an enormous risk with the potential of undermining the international status quo.

In a quintessential case of 'compassionate conservatism', the current Bush administration launched the 'United States Leadership against HIV/AIDS, Tuberculosis, and Malaria Act' in early 2003 as a response to the growing pandemic. At the signing of the legislation, President Bush pointed out that, 'the United States of America has the power and we have the moral duty to help ...' (Bush 2003). Secretary of State Colin Powell, at the same event, also expressed the broad concerns that the US foreign affairs and intelligence elites had about the future impact of the disease: '. . . HIV/Aids is not only a humanitarian and a public health issue', he declared, 'HIV/Aids also carries profound implications for prosperity, democracy and security' (Powell 2003).

Under the G. W. Bush plan, the US pledges $\$ 15$ bn over five years to build a comprehensive system for diagnosing, preventing and treating HIV/AIDS in 12 African countries gravely affected by the disease. This nearly triples US contributions towards fighting the virus, making it the top international donor. In five years the administration hopes to prevent $7 \mathrm{~m}$ new infections, treat $2 \mathrm{~m}$ infected people with anti-retroviral drugs, and care for $10 \mathrm{~m}$ HIVinfected people and Aids orphans. For general prevention, the overall strategy is to spread the successful method used in Uganda, which focuses on abstinence, fidelity and the use of condoms. Most of the spending is allocated to bilateral programmes run by the US, with only a small amount allocated to the multilateral Global AIDS Fund set up by the UN and G8 in 2001. There is an element of uncertainty that remains about the funding of these programmes, however, as they are subject to annual approval of Congress. Although arguments based on morals and compassion may not in themselves 
persuade members of Congress to fund the HIV/Aids programmes, it seems possible that national security considerations will prove decisive.

Some in the current Bush and previous Clinton Administrations are quick to point out that HIV/Aids poses the USA with real economic and security risks. Recent unclassified National Intelligence Council (NIC) reports indicate that the government is increasingly concerned with the spread of the virus. The authors of these reports view HIV/Aids as not only a humanitarian crisis in Africa but also as a security threat to the US, because of the way it has devastated populations, reduced economic growth and threatened governments around the world (NIC 2000a, 2000b, 2002). Economically, HIV/Aids will slow economic growth in highly infected countries by at least 1 per cent GDP annually. Politically, the impact of HIV/Aids on society, and in particular its effects on the ruling political and military elites is likely to become evident in the struggle over the distribution of scarce state resources (NIC 2000a). Furthermore, rising social tensions over HIV/Aids and related economic problems exacerbates regional and ethnic tensions, leaving governments less able to manage the problem (NIC 2000b). Perhaps the greatest potential sources of instability are those militaries that exhibit high infection rates. Prevalence of the disease in African militaries ranges from 10 to 70 per cent (NIC 2002). This is considerably higher - in some cases five times higher than their civilian populations. Some in the US government fear that mounting deaths from HIV/Aids among the military officer corps may lead to a weakening of military institutions and cause some officers to seize power to gain state resources for the purchase of Aids drugs (NIC 2000a). In the case of HIV/Aids legislation, then, it is hard to say whether the US' decision-making process is motivated primarily by realist fears or humanitarian 'compassion'.

\section{Conclusion}

It has been the argument that the promotion of stability has been a core concern of the US policy towards Africa. Exactly the interest in stability can explain many US policy initiatives towards the region. Also it was shown that promotion of stability was linked to the attempts to promote economic development and furthering of democracy and human rights. From time to time, as the public becomes aroused over conflict issues (Sudan, South Africa), the prospect of regional destabilization (Zimbabwe) or the spread of HIV/Aids, the US government has exhibited strong concerns regarding particular African issues. In the large, however, what is striking about US priorities is the relatively low rankings given to Africa's challenges, especially those of peacekeeping and economic development. Searching to maintain stability in the international arena, US interests are limited but nonetheless real in Africa, and no US administration can afford to disengage from conflict management, the enhancement of trade relations and the prevention of disease. In this respect, the second Bush administration typifies much about the American mindset on these African issues. It does identify with long-standing 


\section{Donald Rothchild and Nikolas Emmanuel}

principles on conflict resolution, democratization and human rights and economic betterment, and its actions on enhanced trade and preventing the spread of HIV/Aids are evidence of concern on its part. But this 'compassion' is essentially realist at its core. Not only do these undertakings enhance US interests by promoting the political and economic status quo, but the actions themselves are hesitant and the allocations for the most part minimal.

\section{References}

BBC News, London. Online: <http://www.bbc.co.uk>.

Bush, G. W. (2003) 'US Leadership Against HIV/AIDS, Tuberculosis and Malaria Act of 2003', signing of H.R. 1298, 27 May 2003. Online: <http://www.state.gov/g/oes/ rls/rm/2003/20986.htm>

Cohen, H. (2000) Intervening in Africa: Superpower Peacemaking in a Troubled Continent, New York: St Martin's Press.

Freedom House (2003) Online: <http://www.freedomhouse.org/research/freeworld/ 2003/index.htm>.

Ikenberry, G. J. (2000) 'America's Liberal Grand Strategy: Democracy and National Security in the Post-War Era', in M. Cox, G. J. Ikenberry and Y. Inguchi (eds), American Democracy Promotion: Impulses, Strategies, and Impacts, Oxford: Oxford University Press, 103-26.

Institute for Advanced Strategic and Political Studies/Africa Oil Policy Initiative Group Conference (2002) 'African Oil: A Priority for US National Security and African Development', 25 January 2002.

International Crisis Group (2002) Sudan's Best Chance for Peace: How Not To Lose It, Africa Report No. 51, Nairobi/Brussels: 17 September 2002.

Jentleson, B. W. (1992) 'The Pretty Prudent Public: Post-Vietnam American Opinion on the Use of Military Force', International Studies Quarterly, 36 (1), 49-73.

Kansteiner, W. (1996) 'US Policy in Africa in the 1990s', in J. R. Azrael and E. A. Payin (eds), US and Russian Policymaking with Respect to the Use of Force (CF-129CRES), Santa Monica: RAND. Online: <http://www.rand.org/publications/CF/ CF129/CF-129.chapter7.html>.

Kanter, A. (1996) 'Intervention Decision making in the Bush Administration', in J. R. Azrael and E. A. Payin (eds), US and Russian Policymaking with Respect to the Use of Force (CF-129-CRES), Santa Monica, CA, CA, RAND. Online: $<$ http://www.rand.org/publications/CF/CF129/CF-129.chapter10.html>.

Kieh, G. K. Jr (2003) 'Liberia: Legacies and Leaders', in C. L. Sriram and K. Wermester (eds), From Promise to Practice: Strengthening UN Capacities for the Prevention of Violent Conflict, Boulder: Lynne Rienner.

Lake, A. (1993) From Containment to Enlargement (typescript), Baltimore, MD: School of Advanced International Studies, Johns Hopkins University.

National Intelligence Council (2000a) The Global Infectious Disease Threat and Its Implications for the United States. Online: < http://www.cia.gov/nic/special_global infections.html>.

— (2000b) Global Trends 2015. Online: <http://www.cia.gov/nic/nic_globaltrend 2015.html>.

- (2002) The Next Wave of HIVIAIDS: Nigeria, Ethiopia, Russia, India, and China. Online: <http://www.fas.org/irp/nic/hiv-aids.html>.

National Security Directive: A Dialogue About the Future With Nongovernment 
Experts 75 (1992) 'American Policy Towards Sub-Saharan Africa in the 1990's', 23 December 1992. Online: <http://bushlibrary.tamu.edu/research/nsd/NSD/NSD \% 2075/0001.pdf>.

Ottaway, M. (2003) 'African Priorities: Democracy isn't the Place to Start', International Herald Tribune, 23 May 2003.

PDD (Presidential Decision Directive) 2 (1993) 'Organization of the National Security Council’, 20 January 1993. Online: <http://www.fas.org/irp/offdocs/pdd/ pdd-2.htm>.

PDD 25 (1994) 'Clinton Administration Policy on Reforming Multilateral Peace Operations', 3 May 1994. Online: <http://www.fas.org/irp/offdocs/pdd25.htm>.

Powell, C. (2003) 'Bill-Signing Ceremony for the HIV/AIDS, Tuberculosis and Malaria Act of 2003', Washington, DC, 27 May 2003. Online: <http://www. state.gov/secretary/rm/2003/20969.htm>.

Rotberg, R. I. et al. (2000) Peacekeeping and Peace Enforcement in Africa: Methods of Conflict Prevention, Washington, DC: Brookings Institution Press.

Rothchild, D. (1979) 'US Policy Styles in Africa', in K. A. Oye, D. Rothchild and R. J. Lieber (eds), Eagle Entangled: US Foreign Policy in a Complex World, London: Longman, 304-35.

-(1997) Managing Ethnic Conflict in Africa: Pressures and Incentives for Cooperation, Washington, DC: Brookings Institution Press.

(2002) 'The United States and Africa: Power with Limited Influence' in R. J. Lieber (ed.), Eagle Rules? Foreign Policy and American Primacy in the Twenty-First Century, Upper Saddle River, NJ: Prentice-Hall, 214 40.

- and Emmanuel, N. (2003) US Public Opinion and Intervention in Africa's Ethnic Conflicts, paper presented at the International Studies Association, Portland, Oregon, February 2003.

_ and Ravenhill, J. (1983) 'From Carter to Reagan: The Global Perspective on Africa Becomes Ascendant', in K. A. Oye, R. J. Lieber and D. Rothchild (eds), Eagle Defiant: United States Foreign Policy in the 1980s, Boston, MA: Little, Brown, 337-65.

Schraeder, P. (1994) United States Foreign Policy Toward Africa: Incrementalism, Crisis, and Change, New York: Cambridge University Press.

UNCTAD (UN Conference for Trade and Development) (2001) 'Energy services in international trade: development implications', June 2001. Online: <http://www. unctad.org $>$.

USAID (2003) Congressional Budget Justifications, Washington, DC. Online: < http:// www.usaid.gov/pubs/cbj2003/>.

US Department of Energy/Energy Information Administration (2002) 'Imports of Crude Oil into the United States by Country of Origin, 2002'. Online: <http://www. eia.doe.gov/neic/rankings/crudebycountry.htm>.

USTR (United States International Trade Commission) (2003a) 'Sub-Saharan Africa: US exports, imports, and trade balance, annual and year-to-date from Jan-Apr 2003'. Online: <http://reportweb.usitc.gov/africa/trade_balance.jsp>.

(2003b) 'Sub-Saharan Africa: US exports, imports, GSP imports, and AGOA imports, by major commodity sectors, annual and year to date January-March, 2003'. Online: <http://reportweb.usitc.gov/africa/by_country_agoa.jsp>.

Washington File. Online: <http://usinfo.state.gov/products/Washfile/>.

Western, J. (2002) 'Sources of Humanitarian Intervention: Beliefs, Information, and Advocacy in the US Decisions on Somalia and Bosnia', International Security, 26 (4), 112-42. 


\title{
6 Japan The tenor and the terrain of
foreign policy towards Africa
}

\author{
Bolade M. Eyinla
}

\section{Introduction}

When Japan regained its sovereignty in 1952, the country's governing elite was more concerned with domestic reconstruction and economic development than with foreign policy engagements. The foreign policy of Japan emphasized three issues: economic growth, minimal defence spending and friendly relations with the US. The psychological and attitudinal setting of Japan's foreign policy in the period after 1952 has been to avoid taking a lead on international political issues. Its Africa policy evolved within this context and it has been governed by three interrelated and mutually reinforcing factors. These are the necessity of Japan's own economic needs, the demands of the Japan-US Security Treaty and the search for an international role and prestige.

The emergence of Japan as a major industrial nation and its quest for export markets and resource security facilitated the establishment of diplomatic relations with African states. There is no doubt that commercial motives have been extremely strong for Japan to involve itself in Africa. On the one hand, the policy towards the continent has aimed to expand the volume of its export and on the other hand, there has also been a strong interest in African states as suppliers of raw materials. The expansion of Afro-Japanese trade relations was however hampered by the continued stranglehold of the erstwhile colonial masters on African economies and the application of trade restrictions under GATT $\$ 35$ by the newly independent African states. Building positive relations with Africa was one of the options adopted to solve this problem. The use of development assistance as a foreign policy instrument for the establishment of positive relations was particularly evident in relation to Africa. The rapid expansion of the economy based on accumulating balance of payment surpluses soon gave it the capability to start an aid programme, becoming a founding member of the OECD DAC in October 1961.

Meeting its obligations under the Japan-US Mutual Security Treaty (Morikawa 1997: 18-22) was another factor that propelled Japan into Africa. To be sure, Japan's desire to complement and reinforce US ideological and geo-strategic interests in the spirit of burden sharing is an important 
component of its foreign policy (Kajima 1965: 191-2). Consequently, Japan's Africa policy was subjected to the exigencies of the Cold War and to a large extent fashioned to follow the US lead in Africa.

Finally, Japan's desire for national prestige and international influence as an increasingly industrialized country dictated its engagement with Africa. Since joining the UN in December 1956, Japan has sought to use the world body to play a role in world affairs commensurate with its economic status (Ogata 1995: 231-70). It has therefore found it expedient to cultivate the goodwill of the African states for their bloc vote, both within the UN system and other international fora (Morrison 1971: A84).

\section{Policy phases}

Four broad phases can be demarcated in the evolution of Japan's Africa policy, corresponding to the changing foreign policy preoccupations in Japan as well as to the changing fortune in the African political and socio-economic environment. First, the period between 1960 and 1972 can be described as the era of nascent relations between Africa and in Japan. Next, the period from 1973 to 1980 is characterized by Japan's search for resource security in Africa. The third phase from 1981 to 1990 coincided with a period of economic stagnation in Africa and increased Japan's aid flow to the continent. Last is the period since 1991, which is typified by Japan's attempt to get seriously involved in African affairs.

\section{Nascent relations between Africa and Japan (1960-72)}

Relations between Japan and Africa began to take shape in 1960 when 16 African states gained independence. Accordingly, Japan established diplomatic relations with each of these states with the hope of establishing positive political relations and expanding trade and investment opportunities. Although in the early 1960s Japan exhibited the traces of a developing country, by 1964 the country had emerged as a major industrial nation. The effect of this development on Japan's external economic relations was quite profound. As the industrial expansion programme progressed, the country's industrial output increased in leaps and bounds with corresponding expansion of its share of the global market. Amidst a deliberate policy of avoiding total dependence on one source of supply to sustain industrial output, Tokyo saw the possibility of procurement access to secure source for the supply of raw materials from Africa. This is particularly true for apartheid South Africa, where Japan invested heavily in the extractive industries to ensure access to certain strategic minerals including coal, chromium, manganese, vanadium, and platinum.

Japan's strategy towards the newly independent African states was twofold: on the one hand establishment of positive relations with openly pro-Western and/or influential non-aligned states (e.g. Kenya, Tanzania), and on the other 


\section{Bolade M. Eyinla}

nurturing good relations with mineral supplying countries (e.g. Gabon, Nigeria, Zaïre, Zambia). Indeed, as each of these African states became independent, Japan was quick to establish diplomatic relations and to start trade talks with them, resulting in friendly relations and the signing of longterm supply agreements of vital raw materials. Positive relations opened up new markets for Japanese goods in Africa. For example in 1962, exports to Africa amounted to 9.2 per cent of Japan's total exports, while imports from Africa amounted to 3.2 per cent of total imports (MOF 1963). Although the value of exports to Africa continued to show an upward trend, the level of imports from Africa remained quite minimal, creating a trend of trade imbalance in favour of Japan. This situation led to the accumulation of heavy trade deficits, reaching about $\$ 1$ bn in 1971 (MOF 1972). As a result, several African states - including Ghana, Kenya, Nigeria, Tanzania, Uganda, and the majority of the former French colonies - threatened or even invoked GATT $\$ 35$ on trade reciprocity against Japan.

But the imposition of discriminatory import restriction against Japan did not dampen its investment drive in Africa's extractive sectors. Several trade missions were dispatched to Africa, and by 1969 'Japanese trade missions seemed to be in almost perpetual circulation around African capitals' (Nishi 1970: 142-50). One of the most significant of these trade missions was the high-powered delegation led by Fumihiko Kono, the chairman of Mitsubishi Heavy Industries, to Congo-Kinshasa (now the DRC), Ethiopia, Ghana, Côte d'Ivoire, Kenya, Nigeria, Senegal, Tanzania, and Zambia in 1970. Resulting from these trade missions and the use of aid and 'Yen loans' as an inducement was a deal on Zambian copper ore and concentrates in 1965. Further agreements were later signed for the exploration and exploitation of cooper in Zaïre and Uganda (1967), in Congo (1968), and for iron ore in Liberia (1971), Guinea (1972), and Sierra Leone (1974), as well as for bauxite in Ghana and Guinea (1971; Owoeye 1984: 282-7).

\section{Search for resource security in Africa (1973-79)}

Between 1973 and 1979 Japan engaged in the search for resource security, especially in the area of energy resources. The oil crisis of October 1973 and the perceived threat of action by commodity and mineral resources producers pushed the country to change its obsession with national security to the quest for resource security (Drifte 1990: 9). The crisis led to cut backs in oil exports to industrialized nations deemed to be sympathetic to Israel. With oil products alone accounting for almost one-quarter of Japan's imports and fuelling its economic growth, oil constitutes the very soul of the Japanese economy. The cut of Arab oil supplies to Japan led to a crash in the Tokyo stock market and the declaration of a state of emergency. Although the Arab states restored oil supplies by December 1973, the Japanese had learnt a hard lesson. Its immediate reaction was to embark on an intense search for alternative sources of supply for mineral resources considered strategic and 
critical to industrial production. This move led to the dispatch of large numbers of Japanese geological teams to Africa, concentrating on Congo (Brazzaville), Niger, Nigeria, and Zaïre to prospect for mineral resources, especially crude oil and uranium. The extent to which Japan was ready to go in ensuring its resource security was demonstrated by its heavy investment in the Rössing Plant in occupied Namibia. Over half of the mine's uranium production was exported to Japan to feed its nuclear power plants (Africa Confidential 1983: 4). The net effect of these endeavours translated to an increase in the value of Japan's cumulative investment in Africa from $\$ 92 \mathrm{~m}$ in 1971 to $\$ 114 \mathrm{~m}$ in 1973 and $\$ 280 \mathrm{~m}$ by 1976 (MOF 1977).

Furthermore, Prime Minister Tanaka announced the relaxation of the tough terms associated with Japanese aid and loans in January 1974. Before then, Japan had been selective in expanding its loans and grants to African states. The new policy thrust included the widening of the scope of aid, the promotion of untied aid, and the inauguration of a scheme whereby the degree of hardness of loans would be proportional to the recipient country's economic situation (Morrison 1994: A102-3). The impact of this policy shift was immediately reflected in the volume of Japanese aid flow to Africa, which jumped from 2.4 per cent in 1973 to 9.7 per cent in 1979. This is apart from general efforts geared towards promoting increased African imports to Japan as a way of persuading the African states to halt continued invocation of GATT $\$ 35$ against Japanese goods. One step in this direction was taken in 1974 with the implementation of preferential tariff scheme, whereby a wide range of commodities from Africa benefited from tariff concessions. This measure helped to boost the level of Japanese imports from Africa from $\$ 1.7$ bn in 1973 to $\$ 3.2$ bn in 1980, although the bulk of imports consisted of crude oil (MOF 1981).

In addition to Japan's search for resource security was the desire to address the growing criticism against it from the African states for expanding trade links with apartheid South Africa. The level of trade had expanded rapidly. So much that by 1982, Japan became South Africa's main export market and second most important trading partner in spite of mandatory UN economic sanctions. To be sure, Japan's record in observing mandatory UN economic sanctions against any targeted country is ambivalent at best and the case of apartheid South Africa was no exception, given the level of Japan's dependence on South Africa for the supply of strategic and critical mineral resources. Thus mandatory UN sanctions or not, Japan was not prepared to jeopardize its economic interest in South Africa for the struggle against apartheid.

Tokyo's diplomatic stone-walling tactics did not succeed in holding back the African states from condemning Japan for its ambivalent policy towards implementing mandatory economic sanctions against South Africa. Beginning in 1973, Japan was routinely criticized and condemned by individual African states, the OAU and the UN Special Committee against Apartheid for its sanction busting practices. Foreign Minister Toshio Kimura had to embark 
on an African tour in October 1974, the first by a Japanese foreign minister, to deflect some of these criticisms. The need to further strengthen Afro-Japanese relations also influenced Foreign Minister Sunao Sonoda's visit to Côte d'Ivoire, Kenya, Nigeria, Senegal and Tanzania in July 1979. Ostensibly, both visits were aimed at deepening the Japanese understanding of the issue of decolonization and the struggle against apartheid. It was however evident that Tokyo was trying to foster and strengthen good relations with the African states.

This was particularly true in the relation to resource-rich and/or pro-West African states such as Gabon, Côte d'Ivoire, Kenya, Malawi, Nigeria, and Zaïre. Special attention was also devoted to cultivating good relations with Tanzania. Although Tanzania was not a producer of any strategic mineral resources, the opinion of President Julius Nyerere was well respected within African diplomatic circles and among the NAM. Japan was therefore quite eager to cultivate his goodwill. Japan not only used development assistance for establishing an enabling environment for its investment, aid was also used for buying political influence (Ampiah 1996: 107-24). In line with this policy, Japan's aid allocation and disbursement favoured resource-rich and politically influential African states, such as Kenya, Ghana, Nigeria, Senegal, Tanzania, Zambia, and Zaïre.

\section{African economic stagnation and increased Japanese aid flows to Africa (1980-90)}

The 1980s are now generally accepted as the years of the locust in Africa (Adedeji 1989). The collapse of commodity prices and the adverse effect of the second oil crisis of 1979 proved devastating to African economies. The early 1980s also witnessed a period when the conservative governments in Britain, the US and other major donor countries were savagely cutting back on their aid budget. In the end, the economy of most of the African states simply went bust, leading to the introduction of Structural Adjustment Programmes (SAP) by the international financial institutions (IFIs).

The early 1980s were also a period when the US was exerting pressure on Japan to reduce its huge trade surplus. Against the background of the strategic aid concept, the US call on Japan for 'burden-sharing' and for greater participation in support of Western collective security arrangements became more frequent and open (Koppel and Orr 1993: 2). Among the policy options suggested by the Reagan administration to the Japanese government in dealing with its trade surplus is that it should increase the volume and scope of its development assistance. In particular, Washington canvassed for increased Japanese assistance to Africa to alleviate some of the adverse socio-economic consequences of SAPs. Coincidentally, the US suggestion corresponded with the release of the report of the Ministerial Council of Comprehensive Security established by Prime Minister Zenko Suzuki in December 1980. In its recommendation, the Council reiterated that although 
the objective of Japan's economic cooperation was to stabilize and improve the welfare of the people in the developing countries, it should be implemented on the basis of Japan's own interest with due consideration of political, diplomatic and economic factors that could enhance Japan's comprehensive national security (MFA Diplomatic Bluebook 1981).

The combination of US pressure and the Ministerial Council's recommendation as well as direct overtures from the IFIs nudged Japan to become receptive to the idea of increased aid flows to Africa. This policy direction was reflected in the new concept of 'development of the developing countries' and 'humanitarian considerations' as the main principles governing Japan's aid policy process. The change from the exclusive pursuit of national interest to promoting socio-economic stability and global peace was demonstrated in Japan's readiness to engage in Africa. The earliest effort in this direction can be seen in its positive contribution to the debate leading to the adoption of the Declaration on the Critical Economic Situation in Africa by the UN General Assembly in 1984. Japan was the only country to make substantial financial contribution to the Special Program for Adjustment in Africa, a special financial window to deal with the enormity of the economic crisis in Africa. Other concrete steps included the extension of about $\$ 500 \mathrm{~m}$ in non-project grant aid to Africa to support SAP efforts (Stein 1998: 27-53) and embarking on a conscious policy of increasing the volume of its 'Yen loans' to Africa. For example, in 1987 , out of the total loans of $\$ 7.037$ bn, only $\$ 290 \mathrm{~m}$, or 4.1 per cent, was disbursed to Africa. By 1988, the volume of loans to Africa increased to $\$ 972 \mathrm{~m}, 8.7$ per cent of the total $\$ 11.156$ bn (OECF 1989) contributions to the World Bank's Special Program for Africa and syndicated loans to African countries involving international financial institutions.

Several reasons had been adduced for the Japanese new-found interest in Africa, especially from the mid 1980s. They include Japan's search for a status befitting its position as an economic superpower. Also cited is its being a nonWestern developed nation and its high level of dependency on the outside world for raw material needs and markets. However, official publications had tried to explain the increased focus on Africa from the mid 1980s as a reflection of Japan's genuine response to meeting basic human needs of a continent in dire straits and should not be interpreted in terms of economic self-interest (MFA Diplomatic Bluebook 1992). While it is quite true that Japan focused more on providing aid for efforts to meet certain basic human needs and humanitarian assistance, Tokyo was still engaged in the quest for diplomatic support from the African states, especially for the re-election of Shiguru Oda, its representative to the International Court of Justice (Morikawa 1997: 171).

\section{Era of direct Japanese involvement in African affairs (1991-present)}

The end of the Cold War and the aftermath of the first Gulf War underlined the need for Japan to re-evaluate the focus and thrust of its foreign policy. The 


\section{Bolade M. Eyinla}

country had suitably adapted its foreign policy framework to the dictates and dynamics of the post World War II international order by avoiding taking initiative or an active role in dealing with international or regional conflicts. Now, for it to remain a key player in a changing international order, it must evolve appropriate policy responses. However, Japan lacked a precedent to fall back on and the institutional capacity to quickly evolve a new foreign policy dictum. Successive Japanese political leaders never thought that the Cold War would come to an end, nor did they envisage the possible demise of the Soviet Union as a superpower or the emergence of China as an important international actor. Soon it became apparent that the dictates of the 'Yoshida Doctrine', which had served the country so well, were inadequate. The process of adjusting was hindered by Japan's customary low-profile foreign policy approach and the lack of experience in dealing with issues of international peace and security. Thus, when the country was confronted with the diplomatic challenge of responding to the outbreak of the first Gulf War in January 1990 and its aftermath, it had no adequate policy response beyond its traditional normal chequebook diplomacy.

However, Japan then started defining its concept of comprehensive security beyond the military sense of security in Asia and the narrow interpretation of its global economic needs. It is within this context that the ODA Charter of June 1993, which somewhat aligned Japan's foreign policy with that of the other member state of the G7, evolved. By this, Japan also began to emphasize civil and political rights, including respect for democratic principles, observance of basic human rights, economic development, and trends in military expenditure and transfer of weapons (Eyinla 1999: 416-20). In the emerging foreign policy dictum, it was reasoned that international peace and security - which is the cornerstone of international economic relations and ultimately of Japan's own wellbeing - could be secured and assured by paying attention to these factors.

With particular reference to Africa, Japan's penchant for non-interference in the internal affairs of other states, which had always made the country circumspect in what it does, at what level it does it and how it does it, began to change. To be sure, the end of the Cold War robbed Africa of whatever strategic importance that accrued to it in the period of East-West confrontation, bringing about a certain level of disengagement on the part of the US and Western Europe. With the increasing unwillingness of these Western powers to interfere in the internal affairs of the African states in support of authoritarian regimes, most of these states were left to their its own devices for the first time in their post-independence period, resulting in political upheavals. The situation was further compounded by the apparent failure of SAPs in most of the African countries (World Bank 1989). Thus, the 1990s began on a very critical note for African political and economic development.

It is against this background that Japan emerged as the only country that was ready to increase the level of its aid flow to Africa, giving some clout to exert influence on the course of political and economic change. It actually 
began to get more directly involved in African affairs. For example, disbursements were increased to African states that were perceived to be taking positive steps towards political and economic reform, such as Benin, Cameroon, Tanzania, Zambia in 1991, Ethiopia and Ghana in 1993 and 1994 respectively, as well as South Africa in 1994. On the other hand, sanctions in the form of aid reductions and/or suspensions were visited on Kenya in 1991, Sudan in 1992, Nigeria and Zimbabwe in 1993, and the Gambia in 1995.

Japan facilitated the organization of the first Tokyo International Conference on African Development (TICAD I) in October 1993, where African states and Africa's development partners pledged to work towards an era of peace and prosperity (MFA 1993). A follow-up conference, TICAD II, was held in October 1998 with the aim of strengthening the emerging partnership for sustainable development between the African states and Africa's development partners, and to re-affirm commitment towards inducing and sustaining economic growth, poverty reduction and promoting peace and prosperity in Africa (MFA 1998). In the aftermath of the TICAD conferences, Japan's Initiatives on Assistance to Africa, comprising assistance for human resources development, was unveiled, including the allocation of huge financial resources to support poverty alleviation, social development, capacity building, democracy and conflict prevention, and debt reduction.

The seriousness with which Japan viewed its African policy in the 1990s was also reflected in the number of high-profile visits to various African states. Tokyo also invited three African heads of state to the July 2000 G8 Kyushu-Okinawa Summit to present their views on the continued need for external support for African development. The clearest indication of the seeming priority position occupied by Africa in Japan's foreign policy considerations was the visit by Prime Minister Yoshiro Mori to Kenya, Nigeria and South Africa in January 2001. During the visit, the first by an incumbent prime minister to Africa, Mori highlighted the broad outlines that the course of Japan's Africa policy will follow in the twenty-first century. Apart from calling for enhanced Afro-Japanese relations, he stressed that the new relations would be developed on the basis of mutual trust, with emphasis on establishing human security in Africa. Claiming 'success or failure in establishing human security in Africa will test the merits of Japan's foreign policy', he declared that there would be no stability and prosperity in the world in the twenty-first century unless the problems of Africa were addressed and resolved (Mori 2001).

This policy declaration was reinforced through the response to the September 11, 2001 terrorist attacks in the US. As part of the measure to deny terrorists safe haven and an operational base in any African state, especially in Kenya and Somalia, Japan emphasized the need to engage in 'outreach activities' towards these countries by providing them with the necessary capacity to fight terrorism, including information sharing and immigration control. Among other measures aimed at complementing the fight against 
terrorism is the initiative to strengthen good governance, the rule of law, human rights and judicial reform, and the analysis of factors that contribute to the emergence of terrorism (MFA Diplomatic Blue Book 2002). Furthermore, specific measures were announced by the government aimed at ensuring Japan's own security against terrorist attack and at safeguarding the life of its citizens abroad, especially the diplomatic corps and the 23,000 members of Japan Overseas Cooperation Volunteers (JOCV), one-third of them dispatched to Africa.

\section{Policy-making}

At the centre of Japan's foreign policy organizational structure is the 'iron triangle of power', which refers to the caucus of the Liberal Democratic Party, top ministerial bureaucrats, and the leaders of Japan's business and banking conglomerates. This iron triangle dominates all aspects of Japanese political life (Drifte 1996: 15-25). The formulation and implementation of the African policy is located in the Middle Eastern and African Affairs Bureau of the Ministry of Foreign Affairs (MFA). Since the policy is mostly seen as routine, non-controversial and involving essentially incremental changes (Fukua 1977: 5), its nitty-gritty is largely left in the hands of the bureaucrats in the First Africa and Second Africa Divisions. However, politically sensitive and highly controversial issues such as trade, aid, food, and fisheries often attract the opinion of political and business leaders, as well as input of bureaucrats from the Ministry of Finance (MOF), Ministry of International Trade and Industry (MITI) and Ministry of Agriculture, Forestry and Fisheries, and lately the Ministry of Defence. The formulation and implementation of Japan's African policy is completely in the hand of bureaucrats of the Foreign Ministry who are largely immune to pressure from domestic and external nonformal foreign policy actors. In fact, it was not until during the preparations for TICAD I in 1993 that NGOs were for the first time invited to participate, albeit tangentially in the African policy process.

\section{Responses to Africa's challenges}

In the post Cold War period Japan was seeking to play a more prominent role in the international community, partly by promoting political stability and economic development in Africa. The process is driven by the country's desire to play a more active political role in world affairs commensurate with its economic capability and has become an important component in the globalization of its foreign policy. With its increasing clout within the multilateral financial institutions and agenda-setting influence on development issues, Japan is now devoting more attention to Africa.

This is based on the premise that Japan is transforming its relations with Africa by developing a more proactive agenda imbued with certain identifiable, albeit symbolic forms and substance. Most evident in this process 
is the 'Partnership for Democratic Development' (PDD) initiative, which is perhaps the most concrete concept ever to emerge in the history of AfroJapanese relations. Under the initiative, Japan is providing institutional support to the legislative, governmental, electoral, and mass media sectors in the various African states. It is also providing active assistance to countries that are making efforts to improve human rights situations. For example, Japan made material and financial contributions towards presidential and parliamentary elections in a number of African states (including Côte d'Ivoire 1995, Liberia 1996 and Tanzania 1995). It also sent out election monitors to observe elections (Liberia 1996, Nigeria 1999, Uganda and Zimbabwe 2000). This is apart from its contribution to the UNDP Human Resources Development Fund to support the African Governance Forum, where African countries undergoing structural reforms discuss their programmes with African development partners.

Japan's search for an international role and accompanying prestige commensurate with its economic might in the post Cold War period necessitated its participation in UN peace-keeping operations. It started in May 1993 when it contributed personnel to the UN Operation in Mozambique (UNOMOZ) and was followed by the dispatch of International Peace Cooperation Corps to Rwanda, support for the demarcation of the borders between Ethiopia and Eritrea, and assistance for the disarmament, demobilization and re-integration of ex-combatants in Sierra Leone. Furthermore, it contributed to the Trust Fund for the Implementation of the Program of Work for the Standing Advisory Committee on Security Question in Central Africa, and facilitated conferences for the Burundi peace process. From 1996 to 2000, Japan also contributed over $\$ 1 \mathrm{~m}$ to the OAU to strengthen its Mechanism for the Conflict Prevention, Management and Resolution. It also gave direct donations to the OAU Peace Fund for the development of early warning systems and conflict-resolution mechanisms. Japan also supported the newly established African Union to facilitate the workings of its Peace and Security Council.

Another post Cold War orientation of Japan's Africa policy was to get more involved in Africa's conflict-prevention and conflict-resolution machinery at the intellectual level through co-sponsoring high-level conferences. They included conferences on 'Peace and Development - Problems of Conflict in Africa' and 'Conflicts in Africa - Road to Nation-Building in the Post-Conflict Period' held in Tokyo in October 1995 and September 1996, respectively. In both conferences, discussions focused on the causes and nature of conflict in Africa and measures to prevent and solve them. Following another International Conference on Preventive Strategy in January 1998, Japan helped in producing a report recommending that the UN and regional organizations should improve the conflict-prevention capacities of the African countries, particularly their early warning systems.

In the area of supporting political stability and democratic principles, Japan developed the practice of making public statements expressing concern. 


\section{Bolade M. Eyinla}

It also issued diplomatic démarches to countries deemed in breach of democratic practices (Eyinla 1999: 423). Based on the recognition that Africa's political stability and development are important issues for the international community, Japan actively contributed to efforts towards conflict resolution and promoting democracy. For example, at the UN Security Council Ministerial Meeting on Africa in September 1997, Foreign Minister Keizo Obuchi stressed the need to strengthen the international community's support for Africa, pledging Japan's active support for the self-efforts of the African states in promoting political stability and political reform processes. Subsequently, he appointed a special ambassador charged with the responsibility of handling African conflict issues and promoting dialogue between countries in dispute.

A new post Cold War development is Japan's quest to bring the positive experience of its development strategy in Asia to bear on Africa. Since the publication of the study The East Asian Miracle by the World Bank in 1993, Japan has sought with other Asian newly developed countries to promote the Asian developmental model of addressing poverty reduction through economic growth as a major strategy for African socio-economic development. It is promoting this initiative by sponsoring various regional workshops across Africa aimed at encouraging economic reform based on the Asian experiences and promoting Asia-Africa cooperation. Likewise, Japan financed the establishment of the Asia-African Forum (AAF), the AsianAfrica Business Forum, and the Asia-Africa Investment and Technology Promotion (HIPPALOS Centre). These institutions were created with the aim of facilitating the exchange of ideas and experience between Asian and African development planners and to promote trade and investment between Africa and Asia. Indeed, in Japanese conceptual thinking these institutions will serve as a vehicle for establishing a triangular North-SouthSouth co-operation by which Asian development experience can be brought to bear in Africa through Asian developing countries, with Japan providing the needed expertise, finance and logistics to facilitate the transfer process.

Development aid is at the centre of Afro-Japanese relations and Africa has been accorded some importance in terms of aid allocation and disbursement since 1990. The volume of Japanese aid flow to Africa reached $\$ 792 \mathrm{~m}$, i.e. 11.4 per cent of Japan's bilateral aid budget in 1990, increased to $\$ 1.33$ bn (12.6 per cent) in 1995 (MFA 1990 and 1995). By 1999, with a total aid flow of $\$ 1.21$ bn (12 per cent), the country became the third largest bilateral donor to Africa after France ( $\$ 2 \mathrm{bn})$ and the USA ( $\$ 1.9 \mathrm{bn})$. It accounted for 8 per cent of the $\$ 15.9$ bn total aid flows to Africa (www.oecd.org/gif/ M000060000). The ultimate aim of the Japanese government is to devote about 15 per cent of its total bilateral aid budget to Africa. Since 1995, Japanese aid to Africa has increasingly taken the form of untied assistance, with about 80 per cent being provided in form of grant aid for the development of infrastructural facilities (JICA 1998). Japan is also working actively 
with other donors and international organizations toward the steady implementation of the Tokyo Declaration of 1993 and the Tokyo Agenda for Action of 1998. Towards this end, it set a goal of providing about $\$ 9$ bn over a five-year period from 1998 to support Africa in the area of basic human needs, including education, health and medical services, as well as water supply hygiene. In addition, Japan was one of the countries within the G7 that pushed for the adoption of the HIPC initiative to deal with the African debt problem. Prior to the April 1999 G7 Cologne Summit, it called for contribution from the industrialized countries to enhance and expand the framework for international debt-relief measures for HIPCs. Since the inauguration of the HIPC Initiative, Japan has written off about $\$ 3$ bn of the approximately $\$ 10.5$ bn of debt owed it by 27 HIPCs, the majority of which are in Africa (MFA 1999a).

Japan has supported humanitarian activities and refugee activities through international organizations, especially the UN High Commissioner for Refugees and the UN Children's Fund. African countries that have benefited from such direct Japanese contributions include Angola, Burundi, the DRC, Ethiopia, Eritrea, Liberia, Rwanda, Sierra Leone, Somalia, and Sudan (Sesay 2000: 40-1). This is in addition to its financial and material contribution towards combating HIV/Aids, eradication of polio and the 'roll back malaria' initiative within the framework of the Japan-US Common Agenda. By and large, it is certain that in the 1990s Japan became a significant donor to Africa, providing a wide range of assistance for structural reform, human resources development and infrastructure development.

\section{Political goals}

This new and activist Japanese Africa policy has to be understood against the background of Tokyo's political aspirations and internationalist ambitions, especially in relation to its ambitions to widen the scope of using the UN as the cornerstone of its foreign policy. For a number of years, Japan has fought strongly in favour of expanding the UN Security Council to reflect regional representation, which was a major item on the agenda of the 48th UN General Assembly in 1993. The question of which countries should become permanent members of the Security Council and the condition of their admission has since become a dominant issue in the politics of the UN.

As the second major contributor to the UN, providing 15.7 per cent of the regular budget, Japan has not hidden its interest in permanent membership of the Security Council. However, it has been careful to avoid an aggressive campaign, preferring a discreet high-level diplomatic approach to members of the General Assembly, especially the African states (MFA 1999b: 26-8). This is based on awareness that India also desires a permanent seat and the background of the harsh diplomatic battle for the Asian-region non-permanent UN Security Council representative seat in 1996, which Japan won by 142 to 40, largely due to the African bloc vote (Morikawa 1997: 171). 


\section{Bolade M. Eyinla}

Constituting nearly one-third of the UN General Assembly, it would be unwise for any country that has the ambition of becoming a permanent member of the Security Council to ignore the African states and their bloc vote. Since any reform package put forward in the General Assembly would be a product of complex negotiations, Japan will need the African bloc vote to enhance its position. Its diplomatic engagement in Africa can therefore be interpreted as a campaign for African votes. To be sure, Japan has a good record in getting African electoral support within the UN system. For example, the African bloc vote was decisive in the election and re-election of Shigeru Oda as a Justice of the United Nations International Court of Justice in The Hague and for the two-term election of Sadako Ogata as UN High Commissioner for Refugees, as well as that of Koichiro Matsuura as the Director-General of the UN Education, Scientific and Cultural Organization (UNESCO).

An examination of Japanese aid flow to Africa over time shows that certain African states have been favoured. This is particularly true for Kenya and Tanzania, as well as Ghana and Nigeria in the early 1990s, though Tokyo did not officially designate them as priority countries. The fact is that Japanese Africa policy is to some extent governed by what Morikawa (1997: 22) referred to as 'the key country approach', which means that a country is given special priority over certain other countries based on economic and geostrategic considerations, covert pressure from the US and/or the Bretton Wood institutions or public-relations purposes. It is certain that in spite of its seemingly altruistic motivation, the pursuit of national interest can still be discerned in Japan's Africa policy. This is evident in Tokyo's rather impotent attitude towards the application of sanctions against Kenya and Nigeria, two countries deemed to be in breach of the democratic and human rights principles. In both cases, where there are some Japanese/American geo-strategic and/or economic interests, Tokyo was slow to act, in spite of its declared determination to sanction any country deemed guilty of stalling the democratization process and/or engaging in egregious human rights violations.

\section{Conclusion}

This review of Japan's Africa policy has shown that paradigm shifts have taken place over time. From 1960 to 1979, the policy was focused on trade and securing access to raw and mineral resources, as well as on complementing US geo-strategic and ideological interests in the context of the Cold War. But from the 1980s, the policy was directed at deflecting African criticism of burgeoning Japan-apartheid South Africa trade relations, mitigating the socio-economic consequences of SAPs, providing humanitarian assistance, promoting Asia-Africa cooperation, supporting poverty reduction strategies and meeting human basic needs, and enhancing Japan's international stature.

When Foreign Minister Fujiyama Aiichiro outlined Japan's Africa policy at the UN General Assembly in December 1957, he stated Japan's belief in 
the settlement of disputes by peaceful means and close cooperation with the other Western powers (MFA 1958: 4). His country's commitment to this principle was demonstrated in its pacifist attitude and the attempt at policy coordination with the members of the Western alliance during the struggle of African states to end Portuguese colonial/white-minority rule in Southern Africa, as well as to end apartheid and attain black-majority rule in South Africa. Consequently, unlike Japan's policy towards South East Asia, which is sometimes conceived independently, there is a tendency to subject and tune policy towards Africa to the whims and caprices of the US and Western Europe.

In summary, Japan's policy in Africa has been influenced by the search for resource security which has opened it to African criticism of Japan-South Africa economic relations. Afro-Japanese relations were particularly fostered by the attempt of the African states to dilute the residual powers of their erstwhile colonial masters, and the fact that many African leaders saw Japan as a non-Western and 'non-white' country that has made it to the pinnacle of technological development. Japan's ability and preparedness to extend fairly substantial amounts of economic aid to key African countries to secure access to their important mineral resources and to establish and promote positive and friendly relations was also an important factor.

Unfortunately, the progressive decline in economic fortunes and the spate of political instability in Africa from the early 1980s helped to reinforce for the Japanese the stereotyped image of Africa as an 'uncivilized and starving continent'. This negative image of Africa had somewhat shaped public perception in Japan, as many Japanese see Africa as a region of the world where their country's interest is minimal and superficial. Moreover, Africa is still considered by many Japanese political leaders as a remote and unfamiliar policy terrain at best. It is partly to correct this impression that the Japanese government began to engage in efforts to promote political stability and economic development in Africa. The most visible action in this regard was TICAD I and II, which both aimed at mobilizing international support for African development and expanding the scope of activities of Japanese NGOs in Africa. Preparatory efforts to convene TICAD III in October 2003 and to establish a complementary relationship between that process and NePAD as a framework were a further indication that the TICAD process had become the cornerstone of Japan's Africa policy.

\section{References}

Adedeji, A. (1989) Towards a Dynamic African Economy, London: Oxford University Press.

Africa Confidential (1983), 24 (10), 4.

Ampiah, K. (1996) 'Japanese Aid to Tanzania: A Case of the Political Marketing of Japan in Africa', African Affairs, 95 (378), 107-24.

Drifte, R. (1990) Japan's Foreign Policy, London: Routledge. 
-(1996) Japan's Foreign Policy in the 1990s. From Economic Superpower to What Power?, London: Macmillan.

Eyinla, B. M. (1999) Aid as an Instrument of Political Reform: A Study of Japan's Aid Policy in Sub-Sahara Africa, Tokyo: IDE-JETRO.

Fukua, H. (1977) 'Policy Making in Japanese Foreign Ministry', in R. A. Scalapino (ed.), The Foreign Policy of Modern Japan, Berkeley: University of California Press.

JICA (Japan International Co-operation Agency) (1998) Annual Report 1998, Tokyo: JICA.

Kajima, M. K. (1965) A Brief Diplomatic History of Japan, Rutland: Charles Turttle.

Koppel, B. M. and Orr, R. M. (eds), (1993) Japan's Foreign Aid: Power and Policy in a New Era, Boulder, CO: Westview Press.

MFA (Ministry of Foreign Affairs) (1958) Statements Delivered by Delegation of Japan During the 12th Regular Session of the General Assembly, Tokyo: MFA.

- (1993) First Tokyo International Conference on African Development (TICAD I) Tokyo Declaration on African Development Towards the 21st Century, 6 October 1993.

(1998) Second Tokyo International Conference on African Development (TICADII) African Development Towards the 21st Century: The Tokyo Agenda for Action, 21 October 1998.

_ (1999a) Japan's Basic Position on the Debt Problem Faced by the Heavily Indebted Poor Countries (HIPCs), Tokyo: MFA.

- (1999b) In Quest of a New Role, UN and Japan, Tokyo: MFA. (1981-2002) Diplomatic Bluebook 1981-2003, Tokyo: MFA.

MOF (Ministry of Finance) (various) Annual Report of Customs and Tariff 1962-1999, Tokyo: MOF.

_ (various) Outward Direct Investment By Country and Region 1963-2000, Tokyo: MOF.

Mori, Y. (2001) 'Africa and Japan in the 21st Century', speech by Prime Minister Mori at Gallagher Estate, Midrand, Republic of South Africa, 9 January 2001.

Morikawa, J. (1997) Japan and Africa. Big Business and Diplomacy, London: Hurst.

Morrison, G. (1971) 'Japan's Year in Africa', in C. Legum and S. Hughs (eds), Africa Contemporary Records, Annual Survey and Documents 1970-1971, London: Rex Collings.

(1974) 'Japan's Year in Africa', in C. Legum, R. Synge and E. Clements (eds), Africa Contemporary Records, Annual Survey and Documents 1973-1974, New York: Africa Publishing Company.

Nishi, K. (1970) Economic Cooperation: A Way towards Japan as a Political Giant, Tokyo: Chuo Koronsya.

OECF (The Overseas Economic Cooperation Fund) (various) Annual Reports 1988-1999, Tokyo: OECF.

Ogata, S. (1995) 'Japan's Policy towards the United Nations' in C. F. Alger, G. M. Lyons and J. E. Trent (eds), The United Nations System: The Policy of Member States, Tokyo: United Nations University Press.

Orr, R. M. (1990) The Emergence of Japan's Foreign Aid Power, New York: Colombia University Press.

Owoeye, J. (1984) 'Africa and Japan's Search for Resource Security', Africa Spectrum, 19 (3), 279-89.

Sato, M. (1994) 'Japanese Strategy in Africa: The Case of Mozambique', Review of African Political Economy, 21 (59)F, 105-10. 
Japan: The tenor and the terrain of foreign policy towards Africa 107

Seddon, L. and Sato, M. (1997) 'Japanese Aid and Africa', Review of African Political Economy, 24 (71), 153-6.

Stein, H. (1998) 'Japanese Aid to Africa: Patterns, Motivation and the Role of Structural Adjustment', The Journal of Development Studies, 35 (2).

Sesay, A. (2000) Japan's UN Peacekeeping Operations: Implications for Africa, Chiba, Japan: Institute of Developing Economies.

World Bank (1989) Sub-Sahara Africa: From Crisis to Sustainable Growth, Washington, DC: The World Bank. 


\title{
7 Germany \\ Between value-based solidarity and bureaucratic interests
}

\author{
Ulf Engel
}

\section{Introduction}

Germany's Africa policy is characterized by a twin paradox: First, there is a striking difference between Germany's role as a major international player vis-à-vis Africa ever since its readmission to international politics after 1955 on the one hand, and the conspicuous lack of political or economic interest in Africa on the other. Germany is the second to fourth single most important bilateral donor in sub-Saharan Africa. On average it has been the second most important trading partner in these countries and the fourth most important source of Foreign Direct Investment (FDI). At the end of the Cold War Germany maintained a dense diplomatic network with 40 fully-fledged diplomatic missions in sub-Saharan Africa. Yet, second, this relative importance - as seen from an African perspective has not translated into substantial academic interest. There are few, and mainly these are descriptive, exceptions to this picture, like the contributions to the edited volumes published by Bley and Tetzlaff (1978) and Steinweg (1982), and some articles by Hofmeier (2002, 1986). These are based in structuralism and a rational-choice logic of appropriateness, although this has rarely been made explicit (along this line see also Jungbauer 1998). Some contributions were inspired by concern over the government's Southern Africa policy (Czempiel 1976, Bley and Tetzlaff 1978). Visiting African scholars added to this knowledge (Geldenhuys 1984; Kum'a Ndumbe III 1992; Eyinla 1996). Some insights came from country studies, mainly on those countries that also interested the media, like Namibia or South Africa. Apart from regular monitoring by Germans in 'Africa Contemporary Record' (1970/71-1987/88), very few non-German academic contributions can be singled out (cf. Payne 1990; Jabri 1990). Typically, German Africa policy seldom featured in comparative analysis. Overall, academic concern for Germany's Africa policy has been marked by little reference to IR as a discipline or to African Studies (cf. Engel and Kappel 2002b). Only recently have attempts been made to introduce new theoretical and methodological perspectives. 


\section{Policy phases}

Five distinctive phases of Africa policy can be identified over the period between 1949, when Germany started developing its Africa policy, and 2000 , when the latest change occurred. All phases are characterized by the absolutely marginal position of Africa in the spectrum of Germany's international relations. Sometimes Africa gained prominence when it was instrumentalized for other policy purposes, but most of the time Africa policy was conducted beyond public attention and without a clear set of hard interests in mind (Mair 2002). Africa policy has become synonymous with the efficient, technical and depoliticized administration of development assistance relations. Continuity prevails, though there have been policy changes and paradigmatic innovations that call for interpretation.

The first embryonic phase of Africa policy, 1949 to 1959, was marked by the severely limited sovereignty of the newly founded Federal Republic of Germany in international relations (Engel 2000a: 35-115). It was only by the mid 1950s that West Germany developed administrative structures to conduct a foreign policy. Generally, it was the private sector and trade interests that brought back Africa onto the agenda. West Germany's emancipation from Allied control started in foreign economic politics, rather than in foreign affairs. When West Germany entered the bipolar post war order it was on the side of its main ally, the US. Politically, the government of chancellor Konrad Adenauer of the conservative Christian Democratic Union (CDU) carefully respected the colonial spheres of interests of Bonn's new partners in Europe, inter alia the colonial powers Britain, Portugal, France, and Belgium. So when West Germany started developing its own Africa policy and re-established diplomatic relations, old bonds played a crucial role, including apartheid South Africa, Liberia and imperial Ethiopia.

The second phase of German Africa policy, 1959 to 1972, was marked by the emergence of a heavily biased Africa policy that was strongly influenced by West Germany's own form of Cold War politics. Bonn's main foreign policy interest was to fully re-establish itself internationally, while at the same time preventing international diplomatic recognition of East Germany. In order to uphold its claim to be the only legitimate German state, West Germany instrumentalized its slowly emerging foreign policy in Africa, which basically was conducted through formal diplomacy, establishing networks of bilateral agreements in all fields and, increasingly, disbursing aid. Hence, West Germany nurtured its new partners. But if these partners decided to establish relations with East Germany, this was regarded as an 'unfriendly act'. In accordance with the so-called Hallstein doctrine, Bonn threatened to withdraw aid and, ultimately, to break off diplomatic relations entirely. Africa policy was instrumentalized as a part of 'Deutschlandpolitik'. Tanzania was the first state in sub-Saharan Africa to face this policy (Engel 2000a: 117-45). Nevertheless, aid relations slowly established a rationale outside, though not 


\section{Ulf Engel}

independent of, Cold War politics, particularly after 1961 when a separate ministry for development co-operation, the BMZ, was established. Both ministerial staff and newly established aid agencies started defining interests, which increasingly fell outside the thinking of the Hallstein doctrine. Politically, the doctrine had proven to be counterproductive when developments in the Middle East forced Bonn to tolerate the doctrine's permanent undermining. In 1969 Sudan became the first sub-Saharan state to formally recognize the GDR.

The break-up of an interregnum 'big coalition' made up of the CDU and the Social Democratic Party (SPD, 1966-9) and the formation of a SPD-led coalition government, with the 'liberal' Free Democratic Party (FDP) as a junior partner, in October 1969, signalled changes in Africa policy, too. Chancellor Willy Brandt's new pragmatic 'East policy' towards Poland, the Soviet Union and ultimately East Germany, the admission of the two German states to the United Nations in September 1973 as well as the Helsinki process on security and co-operation, CSCE, unfolding in Central Europe, finally permitted the abandonment of the Hallstein doctrine. Instead, Bonn adopted a policy of 'promoting peace in Africa'. In this third phase of German Africa policy, 1969 to 1982, the 'realist' Cold War policy agenda faded away in favour of an 'idealist', developmentalist agenda under the slowly emerging banner of global governance. Politically, West Germany ceased to pursue hard interests vis-à-vis Africa; economically, it followed what could be described as 'embedded liberalism' rather than particular sector-based interests (either in promoting export lines or securing strategic imports). Instead, changes in Africa policy were increasingly driven by external role expectations. Through a mix of strategic action, social learning and changes in organizational culture, new rules of engagement were established little by little. Indeed, West Germany's entrance into global politics was not accepted lightly, as heavy criticism was laid at Bonn's door by the Afro-Asian majority at the UN General Assembly regarding its collaboration with the South African apartheid regime and its position on Namibia (at the same time, the GDR presented herself as a close ally of the liberation movements). In practice, this made fundamental policy changes inevitable. Under the new government of chancellor Helmut Schmidt (SPD) and his firm grounding of German foreign policy in the context of the European Community (EC) and European political cooperation, new directions in Africa policy were defined after 1974. The most obvious concerned the Namibia question (Engel 2000a: 147-84). West Germany tried to distance itself from any collaborative policies vis-à-vis apartheid South Africa, carefully developed contacts with the liberation movements and became a proactive member of the Namibia initiative of the so-called Western Contact Group, which then developed the independence plan laid down in UN Security Council Resolution 435 of 1978 (cf. Jabri 1990).

After 1982, with the collapse of the Resolution 435 initiative, the change of government in West Germany back to a CDU-led coalition, and Africa's 
emerging debt and food crisis, the Foreign Office lost its lead role in Africa policy to the Development Ministry. In the fourth phase of German Africa policy, 1982 to 1990 , agenda-setting increasingly became the domain of the BMZ, seemingly 'technical' questions gained and 'political' questions lost importance, save for the apartheid problem. South Africa policy was dominated by personal rivalries between the two smaller parties in chancellor Helmut Kohl's government coalition, the Bavarian Christian Social Union (CSU) of the late Franz-Josef Strauß, which was in charge of the BMZ, and the FDP of Foreign Minister Hans-Dietrich Genscher, who held on to the Foreign Office (Wenzel 1994). Throughout the 1980s the government carefully balanced diplomatic pressure from the EC's majority, which wanted to impose mandatory economic sanctions on South Africa, on the one hand, and its own interest in unhindered relations with South Africa on the other (Engel 2000a: 185-217).

With the unification of East and West Germany in October 1990, a new phase in Africa policy began (1990-8), clearly dominated by the West German heritage - simply because the East German legacy was rejected outright (Engel and Schleicher 1998). The united Germany's Africa policy was marked by etatist continuity, limited programme innovation, and the quest for a new identity. The 1990s saw the arbitrary co-existence of different strands of Africa policy, pursued by different ministries and agencies, all in search of a new paradigm and, ultimately, a new role for Germany in Africa, too (the last Allied reservations on Germany's sovereignty were given up in September 1990). Ideologically, the new policy followed the World Bank, Britain and France, and absorbed the international and, increasingly, global good governance discourse. It, thus, added a political perspective to the policy of economic reconstruction of Africa, which it already had been practising in accordance with the international finance institutions (IFIs) since the early 1980s. The BMZ laid out its policy of political conditionality in 1991, the Foreign Office followed suit in 1993. Hence two new political intervention areas were identified: democratization (Diaby-Pentzlin 2002) and crisis prevention (Mehler 2002).

In September 1998 the New Labour style SPD and the protest/environmentalist Green Party (B90/Grüne) had been voted into power. Subsequently, Germany entered a new phase in its Africa policy, although the first half of the term, by and large, was hallmarked by symbolic politics only. Thus, the promotion of human rights, a debt waiver campaign and an ostensible conflict prevention debate had to make up for real policy changes (Engel 2000b). However, since early 2000 Africa's place in Germany's public policy discourse has changed for two reasons. First, there were increased levels of concern in view of continued budget cuts in development assistance in general and second, partly as a consequence of the former, a new quality of public debate on Africa in particular (Engel 2001). Since, high-level diplomacy has been intensified with Foreign Minister Joschka Fischer (B90/Grüne) touring the continent twice, the German parliament, the Bundestag, has held a 


\section{Ulf Engel}

number of major debates on Africa policy. Different players - political parties, line ministries, NGOs, and social scientists - have published farreaching policy papers on Africa. With the intensified debate on the New Partnership for Africa's Development (NePAD) in 2002, new levels of public support and political commitment for Africa policy were reached - though in practice little has changed. Partly this renaissance of Africa as a policy field is a reflection of Germany's definite arrival in the post-Cold War era and a related discussion on what exactly constitutes an 'interest' in foreign policy. Amid budget controversies and Africa's prolonged marginalization in foreign trade, development assistance and diplomacy, the exact nature and aim of German Africa policy is still subject of debate (Engel 2002). It seems that September 11, 2001 can be seen as a marker of a new phase of policy in Germany. However, initially the caesura was felt more in domestic than in foreign policy, let alone Africa policy. There is a trend towards the creation of a preventive mentality. The constitutional state is gradually to be replaced by a security and prevention state. In this context, in Germany's Africa policy two ministries managed to reposition themselves and, partly, strengthen their impact on Africa policy. In the aftermath of the attacks, the BMZ increasingly portrayed development aid and poverty relief as a contribution to the 'war against terror' (leading to increased budget allocations). And the Ministry of Defence issued new guidelines for defence, in which a 'comprehensive conflict prevention and crisis management policy', inter alia through historically very rare - deployments out of the NATO area, became a cornerstone (Germany contributed a naval force and 1,400 marines to the Allied operation 'Enduring Freedom', patrolling the Indian Ocean and the bordering Arab waters around the Horn of Africa). September 11 reinforced perceptions on the 'threat' coming from 'failed states'. Yet so far, few practical conclusions have been drawn from this threat analysis.

\section{Policy-making}

Germany's Africa policy is bureaucratic in nature and based on a fairly complex set of actors. Constitutionally, it is a domain shared by the executive and the legislature. De facto, the former dominates. Overall political directives rest with the Chancellor ('Richtlinienkompetenz'). His power is delegated to ministers, based on the principle of personal responsibility. Technically the federal government's rules of internal procedures allot prime responsibility for Africa policy to the Minister of Foreign Affairs. Yet de facto this policy field is stretching far beyond this narrow scope. Since all regional policies are structured by issues such as trade, investment, agriculture, etc., other line ministries come in frequently. In practice, the decision-making process is driven by routine administration of bi- and multilateral aid relations. Hence the major implementation agencies for development assistance became key actors. While national non-governmental actors matter, decision-making is increasingly transnational in nature, with the EU as the main point of 
reference. Thus, the locus of decision-making has shifted over time: from the Foreign Office to the BMZ and from there to the implementation agencies; from the political capital to networks of transnational bureaucrats organized around the EU, and - to a lesser extent - the OECD and the IFIs (here, and in the following, see Engel 2000a).

In the field of Africa policy the Chancellor rarely executed his prerogatives. Disputes on questions of Africa policy among cabinet members or between line ministries are relatively rare. Policy changes usually do not take the form of single-case decisions, but are the result of collective decisions taken over time in political-administrative bargaining processes. However, there have been few and only isolated cases that offer symptomatic insights. In the negotiations leading to the establishment of the European Economic Community (EEC) in 1957, the Foreign Office disagreed with the ministries of Finance and Economic Affairs respectively on the need and limits of compromise with France over the question of German 'burden-sharing', i.e. financing France's colonial pre-carré (the association of French colonies to the EEC) in exchange for a successful conclusion of the treaty (Engel 2000a: 225-30). In the interest of reconciliation with the 'arch enemy' France, and Germany's fast reintegration into Western Europe, the Foreign Minister and his permanent secretary overruled opposition from the Foreign Office's Africa desk as well as Finance and Economics. Chancellor Adenauer (CDU, 1949-66) was not interested in these details. Likewise, Adenauer's selfproclaimed political grandson, Kohl (CDU, 1983-98), did not take sides in the strong disagreements between his junior coalition partners, CSU and FDP, on apartheid and sanctions. Rather he exercised great skill in not taking any decision that would destabilize his government. The most regular form of conflict, however, is not over political or economic questions, but on budget allocations for development assistance. Here the minister in charge of the BMZ has always been in a weak position, yet only once did a minister resign because of budget cuts (Erhard Eppler, SPD, in July 1974).

It was only during the 1960s and in the context of Cold War politics that West German chancellors felt the need to engage themselves directly in the conduct of Africa policy. In this case, the issues at stake tended to translate matters of bilateral relations into crisis decisions once the menace of an 'unfriendly act' was perceived. The Hallstein doctrine thus created a policy environment of over-politicization, which led to the permanent reproduction of crisis decision-making situations (as opposed to routine), which necessitated regular Cabinet involvement. A somewhat similar but very brief constellation occurred in the late 1970s when Schmidt (SPD, 1974-82) felt the need to lend his political weight to West German efforts to normalize relations with the Southern African frontline states (to this end he paid visits to Nigeria and Zambia in June 1978). Though the President of the Republic is a strictly ceremonial office, some incumbents exercised their discretion to influence public policy debate or Germany's international reputation. Richard von Weizsäcker (CDU, 1984-94), for instance, was openly critical of the double 


\section{Ulf Engel}

standards employed by the ruling coalition with regard to the rejection of sanctions to combat apartheid.

In practice, Africa policy decision-making rests with the Minister of Foreign Affairs. Personal involvement is not the rule, although occasionally the combination of quest for international reputation and idiosyncratic factors, like moral concern or profile seeking, resulted in the minister's personal involvement, for instance the Namibia policy of Genscher's (FDP, 1974-92). Routine situations are either handled at the level of permanent secretary, as the head of the bureaucracy, or director of African Affairs. While in the 1960s the skilled permanent secretary Karl Carstens (who later became president of the Federal Republic, 1979-84) took an unusual load of work related to Africa - again as a result of over-politicization - his successors usually delegated Africa issues to the level of Africa director, a position which was introduced in 1972 to co-ordinate the two Africa desks established at that time (the Africa director, or 'Afrika-Beauftragter', is head of a subdivision in the Political Department of the ministry). Africa directors have played their role in different ways, some proactive and with a willingness to use all the leeway allowed by the minister or his mandarins (Helmut Müller 1977-9, or Harald Ganns 1993-8), others with little obvious enthusiasm. A special role was played by the head of the Foreign Office's planning unit, Klaus Kinkel (1977-8), during the time when West Germany was a member of the UN Security Council and dealt with the Namibia question (he later became Minister of Foreign Affairs, 1992-8).

The day-to-day management of Africa policy is the domain of the Africa subdivision. Since 1972 comprising two separate desks, its size and composition has varied over time - either influenced by political considerations (as in the establishment of a separate third desk to deal with South Africa policy, 1986), financial constraints (re-merger of three desks into two, 1997), or administrative convenience (re-establishment of three desks to open space for fast-track promotions, 2001). In the Foreign Service, two diplomatic missions - New York at the UN and Brussels at the EU - play an important role in multilateral Africa diplomacy. Influence is exercised through the Ambassador or, more often, the Head of the Political Section. Paris, Washington DC or London are far less important, since co-ordination among the Allies is usually done through specialized committees (there is also a separate mission at the OECD in Paris). In Africa, three diplomatic missions have special status: Pretoria, Lagos and Addis Ababa. Since Germany's ambassadors are career diplomats, their real role in decision-making is heavily dependent on personality (and sometimes on political party membership, too).

Among the line ministries, Finance, Economy and Agriculture respectively are important in framing the conditions for Third World policy in general, but their role in Africa policy is usually not an overt one. Therefore the most important line ministry is the Ministry of Development Co-operation (BMZ), which was established as a separate entity in 1961. The rationale behind this move followed a complex set of reasons, such as external (transatlantic 
burden-sharing), internal (coalition arithmetic), ethics (concern for human development), etc. Initially, co-ordination with the Foreign Office and the Economics ministry respectively was done through three inter-ministerial committees, with Finance exercising a right of veto in all three. Up to now, Foreign Affairs has maintained a veto on all 'political' questions. Gradually the BMZ's area of responsibility was extended (1972 sole responsibility for bi- and multilateral technical aid, 1974 for financial co-operation, and 1998 for European development aid - all taken over from Economics). Politically, the factual separation of work between the Foreign Office and the BMZ allowed for a shadow foreign policy, especially when the office was held by the CSU (1982-98) and gave the Bavarian Prime Minister and party leader's representative in the coalition government a platform to counter-balance the policy of Foreign Minister Genscher (FDP). The position of Political Permanent Secretary, equivalent to the British Junior Minister or US UnderSecretary and always a member of Parliament, gave additional leverage. During the 1998-2006 terms, coalition arithmetics led to a combination of SPD minister and Green Political Permanent Secretary (1982-98 CDU incumbents under a CSU minister, during 1991-4 backed up by an additional second secretary from the CSU). With the concentration on aid relations, the de facto role of the $\mathrm{BMZ}$ in terms of agenda setting was a negative function of the Foreign Office's role: during phases of high-level political initiatives, the BMZ was clearly second to the Foreign Office, but once these ceased and Africa policy routine ruled again, the centre of gravity shifted to the BMZ (this was the case throughout the 1980s and 1990s).

Since Germany is firmly embedded in European politics, the institutionalization and development of European development policy has resulted in another, though less obvious and measurable, dislocation of Africa policymaking (Molt 2002). Increasingly, agenda setting is being done in Brussels, not in Berlin. However, the work of European institutions, be it the ministerial Development Council (dissolved in mid 2002) or the Africa Working Group at the level of Africa directors, is rarely part of German public policy discourse. According to conventional wisdom, Germany is underutilizing these structures. In addition to the European Commission, development and Africa policies are directly negotiated in bilateral national commissions. More generally, transnational bureaucracies have gained importance in Germany's development policy over the past 25 years (this also holds for the OECD's DAC, the IFIs, the G8 sherpas and the growing network of interorganizational liaison committees). Africa policy co-ordination with Germany's major allies has usually been smooth, although fundamental differences of interest existed. Generally, Germany's role conception did not provide for confrontational strategies. Thus, it bowed to both French and US pressure for 'burden sharing', in one case accepting financial responsibility for the association of French colonies to the EEC (1957), in the other case establishing a separate Ministry of Development Co-operation (1961). Two approaches were developed to deal with conflict: conflict evasion, and 


\section{Ulf Engel}

concentration on alternative, non-challenged policy tracks. Anticipation of France's interests in Africa always guided Germany's own low-key position, at least in Francophone Africa. Prime importance attached to what has been described by German and French policy-makers as a 'strategic partnership for reconciliation' and the central 'axis (or motor) for the development of European unity' led to an easy and uncritical acceptance of Paris' pré-carre francophone. When Germany disagreed with the US administration of George Bush senior in 1991-2 over the Namibia strategy (Bonn strictly opposed 'constructive engagement'), it chose to pursue what it understood as the original Resolution 435 approach by focusing on fostering internal dialogue between the liberation movement SWAPO and the German-speaking community of Namibia. Germany's perception of dependence on its major allies and the role of their anticipated interests are mirrored by little regular communication with policy-makers from Africa. Working relations are basically maintained by annual negotiations over the aid programme. There is no institutionalized dialogue between Africa policy-makers and resident African diplomats (save for the annual diplomatic get-togethers on New Year's Day and Africa Day).

A special feature of Germany's development policy set-up is the rich organizational landscape of implementation agencies with highly differentiated internal structures. With respect to technical aid, the major player is the German Agency for Technical Co-operation (GTZ), established in 1974 as a private company and situated in Eschborn near Frankfurt am Main. Financial aid is basically under the control of the KfW Development Bank, an entity established by the central government and the federal states in 1948 (based in Frankfurt am Main). In addition there is a multitude of other agencies, partly competing, partly complementing each other, but all contributing to the corporatist penetration of the BMZ and implementation agencies. In the area of financial co-operation, a smaller amount of development assistance is also provided and administered directly by the 16 federal states of Germany. A limited number of technical co-operation projects are conducted through the Federal Office for Geoscience and Raw Materials (BGR, Hannover) and the Physical-Technical Federal Office (PTB, Braunschweig, Berlin). In the realm of personnel co-operation, the Centre for International Migration and Development (CIM) and the German Development Service (DED, modelled on the US Peace Corps) also deploy expatriates. The relative balance within this set-up has changed over time. Although the BMZ negotiates annual (or lately, biennial) bilateral collaboration programmes under the auspices of the Foreign Office, its real impact has been declining. The lack of international structures (there are very few development attachés in Africa - six in 1998) and limited personnel capacities (a staff of 500, of which 50 are in the new capital, Berlin, against GTZ with about 1,000 at headquarters and another 1,500 in 63 Third-World countries) translates into inferior information-gathering and planning capacities. 
Principally, the national dimension of Africa policy-making has been open to input from society. As could be expected in a corporatist state, NGOs (tiers mondists, environmentalists, globalization critics), lobbyists and advocacy groups associated with one of the two big churches have played a significant role in the area of development policy. The churches are also a major donor to Africa (cf. Köhler 2002). Solidarity groups or the anti-apartheid movement, however, hardly had any impact on West Germany's South Africa policy (cf. Kössler and Melber 2002). But in combination, and backed-up by a small number of critical journals, the NGO sector contributed tremendously to keeping Africa on the map. This is even true for private-sector initiatives, like the Afrika-Verein (reconstituted in 1948 for medium-sized merchant enterprises) or the more recent SAFRI initiative of DaimlerChrysler's CEO. With regard to politics, organized private sector interests in the 1970s began to lobby through Brussels rather than Bonn. The political parties - who otherwise dominate almost every aspect of political life in Germany - have so far played a somewhat limited role in Africa policy, although in some cases they have successfully tried to structure new agendas. They also nurtured another rather unique feature of the German foreign policy decision-making system: the political-party foundations that are operated outside of party structures and largely financed through taxpayers' money. These Stiftungen maintain their own offices and back-channels in Africa (cf. Hillebrand and Vinnai 2002). In certain settings, their flexibility, more informal mode of operation and long-standing ties gave them a comparative advantage over traditional development aid instruments.

Since the end of the 1960s Germany has developed an Africa policy that is a true reflection of its growing 'civil power identity' in foreign policy in general and of a European process of collective norm convergence (Engel 2000a: 272f). By and large, this identity is at the heart of Germany's foreign policy culture. Despite variation over time, it frames policy-making and offers decision-makers a stable repertoire of policy orientations. Civil power politics include the partial transfer of sovereignty to international organizations, participation in regime-building, consolidating legal systems, and expanding institutional co-operation, relating particular interests and universal values, developing specific patterns of collective action, etc. However, Germany's Africa policy did not remain free of contradictions. This has been demonstrated, for instance, by the mixed record on applying political conditionality. In some instances hard economic interests (procuring oil and securing mainly private-sector debt) prevented firm action, as in the case of Nigeria. In most cases, lack of action was indicative of the absence of a political agenda. Exceptions include Zaïre, Cameroon, Malawi, Kenya, Togo, Nigeria, and recently Zimbabwe, which are all related to a process of policy harmonization among EU member states, meeting role expectations and demonstrating 'shared values'. According to Mair (2002), these incongruities can partly be explained by the culture that tabooed acknowledging the existence of German 'interests' in foreign affairs after World War II. Even today, the process of 


\section{Ulf Engel}

defining German interests is marked by distortions and lack of conceptual clarity.

\section{Responding to Africa's challenges}

Initially, statements of German Africa policy were drafted by the Foreign Office and took the form of directives for the newly established diplomatic staff in Africa (at conferences of ambassadors in 1959 and 1968; Engel 2000a: 39-41). German-German policy questions, the Cold War, the consequences of decolonization as well as trade opportunities dominated the agenda; Africa appeared as an object, not as the subject of Africa policy. This changed with the introduction of development aid as a policy instrument and the adoption of the UN development agenda - the second decade strategy, including the 0.7 per cent aim - in 1969-70. Africa policy was increasingly equated with development policy. For two decades the only political questions of substance were Namibia and South Africa. In the 1980s the thrust was on structural adjustment, in the 1990s 'good governance', and the array of development aims framed at global governance conferences was adopted. The Foreign Office redefined Germany's Africa policy in 1993 ('Accra Guidelines') and 2002 through a series of sub-regional policy concepts (www.auswaertiges-amt. de). Likewise, the BMZ re-positioned itself (BMZ 1992, 1998 and 2001). Poverty reduction, respect for human rights, and political as well as economic reforms are now at the core of Germany's Africa policy rhetoric. Although the agenda is not coherent, it is sufficiently operational. The challenges for Germany's Africa policy are largely defined by reference to the continent's continued economic, social and ecological malaise: widespread poverty, illiteracy, low human capital formation, low productivity, HIV/aids, high population growth rates, unsustainable development, threatened biodiversity, etc. In addition, a range of political problems have been identified: fragile democratic transitions, continued human rights abuses, widespread corruption, large-scale violent transnational conflicts, 'failed states', etc.

However, despite the gravity of these and other problems, the general perception and subtext is, and always has been, one of cautious optimism. Currently, this seems to be nurtured by the simple existence of numerous political transition processes, the assumed prospects of regional economic integration and the claims of 'African ownership' through NePAD. In fact, Africa policy displayed a broad consensus in the Africa political community, a conventional wisdom that is structuring the interpretation of policy problems and approaches. 'Africanists' in line ministries, implementation agencies and political parties share many implicit normative judgements and general assumptions on how Africa 'works' (cf. Chabal and Daloz 1999). These not only carry strong conceptions of the way power is exercised and politics work in Africa, but also of what constitutes 'development', of how politics and 'development' are related, and what role Germany could and should play in fostering this 'development'. Basically, decision-makers at 
all levels operate on notions of the external world that are deeply rooted in Middle European history and experience. Thus, the African state is conceptualized in terms of the Weberian abstract and impersonal bureaucratic order, based on a separation of public and private. There is little understanding of the scope, logic and implications of neopatrimonial rule in Africa (or, more recently, the existence of oligopolies of legitimate and/or illegitimate violence) - save for reference to a 'tradition-modernity' dichotomy. Ethnicity is often understood in a basically primordialist way. In this view, ethnicity's place as the key variable to explain political processes is increasingly complemented by the perfunctory 'greed' argument of the conflict discourse. State-society relations tend to be seen through the civil society paradigm. However, the reality of a rent-seeking mentality and dominance of primitive capital accumulation in Africa is rather different. As a consequence, the gravity of economic problems in sub-Saharan Africa is severely underestimated, while the potential for economic growth and the role of development assistance is overestimated. The collaborative role of aid in the reproduction of neopatrimonial rule is not addressed systematically.

On the instrumentalist side, the classic canon of politics has been supplemented by the universe of development aid. During the first two phases (1949-69) travel diplomacy and the establishment of a network of diplomatic missions on the continent dominated German Africa policy. Even before the 'second wind of change' in 1960, West Germany had opened embassies in South Africa (as early as 1954), Liberia, Ethiopia, Ghana, Guinea, and Sudan. Between 1960 and 1964 another 26 embassies were opened in quick succession and without any identifiable political rationale, save for being present and keeping East Germany out. By the end of the Cold War Germany maintained 40 embassies in Africa South of the Sahara. This policy was supported by the opening of cultural centres (Goethe Institutes) in several countries and an array of high-level visits and invitations, which were basically ceremonial in nature. With the abandonment of the Hallstein doctrine after 1972, high-level visits of German politicians to Africa became a rarity. And with the end of the Cold War, a sense of normality slowly evolved, furthering Africa's marginalization in Germany's international relations. For financial reasons the Foreign Office started to close diplomatic missions in Africa in 1997 (eight of the 37 within three years; Engel 2002b). The number of culture centres was reduced from 13 to nine.

Development policy is the core of German Africa policy, and the spectrum of aid instruments is at the heart of operational politics. Up to the 1990s the long-term nature of development assistance, rigid financial quotas for the individual co-operation partners and specific budget planning instruments ('Verpflichtungsermächtigungen') left little room for short-term political corrections. In principle this changed with the introduction of political conditionality. However, in practice bureaucratic incrementalism, the selfinterests of the aid machinery as well as historically grown special relations with a number of countries, led to strong continuities in the direction and 


\section{Ulf Engel}

intensity of aid relations. Political opportunism, lack of politicized discourse or fear of reprisals explain why political conditionality was not rigorously applied; when it was, it was in concert with the US or the EU member states. Since 1978 all financial aid was given in the form of non-refundable grants. In 1984 the government started to cancel debts, albeit selectively. On the basis of the 1996 IFI policy, this finally led to a German campaign for general debt waivers for highly indebted poor countries (HIPC-2, at the G7 summit in Cologne in 1999). Berlin's contribution to the $\$ 70$ bn programme has been estimated at $\$ 10 \mathrm{bn}$. In the 1960s and 1970s the provision of aid used to have a strong export-promotion and labour-market role. Today it is largely free of this domestic agenda; in 2000 only 6.8 per cent of ODA commitments were in the form of tied aid (OECD average 16.2 per cent). Over the years the share of the total bilateral German ODA allocated to sub-Saharan Africa remained rather constant, within a range of 24 to 29 per cent (including Northern Africa, ca. 40 per cent). Between 1950 and 1990 West German ODA disbursements to Africa totalled $€ 23.18 \mathrm{bn}$, of which three-quarters went to sub-Saharan Africa, in the form of both financial - programme, project or commodity - and technical aid. In the 1990s annual ODA disbursements to sub-Saharan Africa stood at roughly $\$ 1$ bn. Despite the overall 'watering can' approach, a limited number of African countries received the bulk of German aid.

Due mainly to the costs of German unification, national budget priorities have changed. Throughout the 1990s the BMZ experienced real budget cuts (1992-3, 1996-2000). ODA as a percentage of GNP declined, from 0.42 (1990) to 0.26 (1999). Finally, Germany lost her traditional position as Africa's second-most important OECD donor (in 1998 and 1999 it was fourth after Japan, the US and France). To regain some room for manoeuvre, in August 1999 the new BMZ minister, Heidemarie Wieczorek-Zeul (SPD) followed the example of other like-minded countries in the donor community and announced that both the number of countries eligible for aid and the main areas of engagement in these countries would be reduced. In May 2000 the new 'Schwerpunktbildung', or focus orientation, was presented. In sub-Saharan Africa, initially only 14 out of 47 countries were identified as 'preferential focus countries' - later two more were added - where aid would be concentrated in three main 'sectors' (such as education, health, decentralization, etc.). Another six African countries have been dubbed 'partner countries' (initially nine). In these cases aid will be streamlined, i.e. concentrated on one 'sector' of engagement only. Another nine countries are in the category 'potential partners'. Provided the political and/or economic environment in the respective country changes, development co-operation could be resumed at a later stage. Because 16 states no longer appeared on the list, the number of countries south of the Sahara currently eligible for German aid has thus been reduced from 48 to 22. Despite the emphasis on poverty reduction, critics claim that sectoral financing has never fully matched the rhetoric. 
Multilateral ODA - to the UN family, the World Bank Group and regional development banks, including the African Development Bank - as a percentage of total ODA was ca. 18 per cent on average in 1995-2000. Outside multilateral aid, Germany's contributions to the EU development aid regime are substantial. The principal instrument of Europe's Africa policy (see Chapter 8 in this book) used to be the association of African, Caribbean and Pacific states under the Yaoundé (1963-75) and Lomé (1975-2000) conventions. Up to 1995 Germany used to supply the single largest contribution to the EDF (only for the eighth EDF - worth ECU 13.1 bn - it was second to France, with a share of 23.4 per cent compares to 24.3 per cent). Germany's foreign trade policy aimed primarily at securing access to raw materials and expanding market shares for consumer goods (Kappel 2002). Africa's place within this strategy has changed over time as the continent's economic importance declined. Africa's share of Germany's imports, including North Africa, decreased continuously from a post-World War II high of 9.1 per cent in 1950 to something like 2 per cent in 2000. Exports to Africa - once accounting for 6.0 per cent of West Germany's exports (1954) - have fallen below 2 per cent. Most of Germany's Africa trade is concentrated on North Africa (in 200053.6 per cent of German imports from Africa and 41.6 per cent of its exports to Africa). In sub-Saharan Africa, South Africa and Nigeria are traditionally Germany's most important trading partners (South Africa alone accounts for more than 50 per cent of all imports from subSaharan Africa, ca. 60 per cent of exports). Otherwise, imports are increasingly originating from Africa's oil-producing countries (in 200054 per cent of all imports from Africa). The range of bilateral trade policy instruments is similar to development aid. Major players are the KfW and the German Investment and Development Agency (DEG, which was integrated into the KfW in 2002). Key instruments are government-backed loans, guaranteed credits and insurance for German corporations (Hermes-Bürgschaften, in 2000 Africa accounted for 15 per cent of a total of $€ 1.53$ bn). A new instrument is public-private partnerships, financed by the GTZ. Despite these efforts, German FDI is extremely low, with less than 1 per cent going to Africa. Of this, three-quarters of the recipients are located in sub-Saharan Africa, mainly in manufacturing and especially in the South African automotive industry (that country accounted for 75 per cent or $€ 2.05$ bn of German FDI in sub-Saharan Africa in 2000).

Among the less important instruments of Africa policy is military aid. Arms exports were rather limited in volume. Sometimes they were highly political, like those to apartheid South Africa, or highly controversial, like the tender accepted by South Africa in 1998 for the building of four naval frigates. West Germany offered training courses to a number of pro-Western governments; it also regularly provided small arms to police forces ('Ausstattungshilfe'). Unlike France, for example, Germany did not pursue a military policy option in Africa. However, in the 1990s the conservative CDU-CSU government used Africa as a testing ground for German public 


\section{Ulf Engel}

opinion in redefining Germany's post-Cold War role by opening the way for out-of-area interventions under the umbrella of NATO, first in Namibia (1989-90, border police) and later in Somalia (1993-4, logistical support for Operation 'Restore Hope').

One of the most controversial issues in German domestic politics is its policy towards foreigners. After World War II Germany became an immigration country. Yet there is no immigration law, just a constitutional right for those persecuted for political reasons in their country of origin to apply for asylum. Otherwise, immigration has been governed by labour recruitment campaigns (1962-74) and irregular admission of refugees. Recent attempts to regulate the influx on a quota bases and according to labour-market needs found no bipartisan consensus. The number of African immigrants is low compared to other groups (4.1 per cent of a total of 7.3 million in 2000).

To summarize, all indicators point to a process of marginalization of subSaharan Africa in Germany's international relations. This process started in the late 1960s and has accelerated after the end of the Cold War. In the absence of hard interests, Africa is kept on the agenda by a combination of institutionalized bureaucratic procedures, embeddedness in transnational regimes and acts of value-based solidarity that frequently are nurtured by media reports on Africa's real or perceived disasters.

\section{References}

Africa Contemporary Record (1968ff) Annual Surveys and Documents, ed. by Colin Legum, London, New York: Rex Collings, and Holmes \& Meier, resp.

Auswärtiges Amt (Foreign Office). Online: <http://www.auswaertiges-amt.de>.

Bley, H. (1978) 'Die Bundesrepublik, der Westen und die internationale Lage um Namibia', in H. Bley and R. Tetzlaff (eds), 145-68.

- and Tetzlaff, R. (eds) (1978) Afrika und Bonn. Versäumnisse und Zwänge deutscher Afrika-Politik (Rowohlt aktuell: 4270), Reinbek: Rowohlt.

BMZ (Bundesministerium für wirtschaftliche Zusammenarbeit und Entwicklung). Online: <http://www.bmz.de>.

-(2001) Die afrikanische Herausforderung. Eckpunkte einer strategischen Afrikapolitik (BMZ Konzepte), Bonn: BMZ.

(1998) Konzept für die deutsche entwicklungspolitische Zusammenarbeit mit den Ländern Afrikas südlich der Sahara (BMZ aktuell: 089), Bonn: BMZ.

_-(1992) Entwicklungszusammenarbeit mit den Ländern Afrikas südlich der Sahara in den 90er Jahren (BMZ aktuell: 019), Bonn: BMZ.

Chabal, P. and Daloz, J. P. (1999) Africa Works. Disorder as a Political Instrument (African Issues), Oxford: James Currey.

Czempiel, E.-O. (1976) Friedenspolitik im Südlichen Afrika. Eine Strategie für die Bundesrepublik Deutschland, München: Kaiser Verlag.

Diaby-Pentzlin, F. (2002) 'Democratization and Development Policy', in U. Engel and R. Kappel (eds), 165-77.

Engel, U. (2002) 'Africa Images and Africa Policy - Pleading for Realism', in U. Engel and R. Kappel (eds), 19-37. 
_ (2001) Politik des Augenscheins? Neue afrikapolitische Anstöße von Parteien und Fachministerien (University of Leipzig Papers on Africa, Politics and Economics Series: 55), Leipzig: Institut für Afrikanistik.

(2000a) Die Afrikapolitik der Bundesrepublik Deutschland 1949-1999. Rollen und Identitäten, Münster, Hamburg: Lit-Verlag.

(2000b) 'Still in Search of a Political Agenda: Germany's Africa Policy under the Red-Green Government 1998-99', African Affairs, 99 (394), 113-18.

_ and Schleicher, H.-G. (1998) Die beiden deutschen Staaten in Afrika: Zwischen Koexistenz und Konkurrenz 1949-1990, Hamburg: Institut für Afrika-Kunde.

Engel, U. and Kappel, R. (eds) (2002) Germany's Africa Policy Revisited. Interests, Images and Incrementalism, Hamburg: Lit-Verlag.

Eyinla, B. M. (1996) The Foreign Policy of West Germany Towards Africa, Ibadan: Ibadan University Press.

Geldenhuys, D. (1984) The West German Debate on South Africa's Political Alternatives (Materialen: 2390), Ebenhausen: Stiftung Wissenschaft und Politik.

Hillebrand, E. and Vinnai, V. (2002) 'The Friedrich-Ebert-Stiftung and German Policy on Africa. Some Remarks', in U. Engel and R. Kappel (eds), 127-39.

Hofmeier, R. (2002) 'Five Decades of German-African Relations: Limited Interests, Low Political Profile and Substantial Aid Donor', in U. Engel and R. Kappel (eds), 39-62.

-(1989-2001) 'Deutsch-afrikanische Beziehungen', in Institut für Afrika-Kunde and R. Hofmeier (eds), Afrika Jahrbuch, Opladen: Leske + Budrich (annual overviews).

- (1986) 'Aid from the Federal Republic of Germany to Africa', Journal of Modern African Studies, 24 (4), 577-601.

-(1978) 'Möglichkeiten und Grenzen deutscher Entwicklungspolitik gegenüber Afrika', in H. Bley and R. Tetzlaff (eds), 192-253.

_ et al. (eds) (1981) Die wirtschaftliche und rohstoffpolitische Bedeutung Afrikas und seiner einzelnen Regionen (Südafrika, Schwarzafrika, Nordafrika) für die Bundesrepublik Deutschland, Hamburg: Institute für Afrika-Kunde.

Jabri, V. (1990) Mediating Conflict. Decision-making and Western Intervention in Namibia, Manchester, New York: Manchester University Press.

Jungbauer, A. (1998) Deutsche Afrika-Politik in den 90er Jahren (Politikwissenschaft: 54), Münster, Hamburg: Lit-Verlag.

Kappel, R. (2002) 'Germany's Economic Interest in Sub-Saharan Africa: The Silent Agenda', in U. Engel and R. Kappel (eds), 153-64.

Köhler, V. (2002) 'Comments on the Role of the Churches in Germany's Africa Policy', in U. Engel and R. Kappel (eds), 141-52.

Kössler, R. and Melber, H. (2002) 'The West German Solidarity Movement with the Liberation Struggles in Southern Africa. A (Self-)critical Retrospective', in U. Engel and R. Kappel (eds), 103-26.

Kum'a Ndumbe III (1992) Was will Bonn in Afrika? Zur Afrikapolitik der Bundesrepublik Deutschland, Pfaffenweiler: Centaurus-Verlagsgesellschaft.

Mair, S. (2002) 'German Interests and German African Policy', in U. Engel and R. Kappel (eds), 9-17.

Mehler, A. (2002) 'Crisis Prevention: A New Paradigm for Germany's Africa Policy', in U. Engel and R. Kappel (eds), 179-88.

Molt, P. (2002) 'Ein neuer Realismus in Entwicklungspolitik', International Politik, 57, 4, pp. $63-70$. 


\section{Ulf Engel}

Payne, R. J. (1990) The Nonsuperpowers and South Africa. Implications for US Policy, Bloomington, IN: Indiana University Press.

Steinweg, R. (ed) (1982) Hilfe + Handel = Frieden? Die Bundesrepublik in der Dritten Welt, Frankfurt am Main: Suhrkamp.

Wenzel, C. (1994) Die Südafrika-Politik der Bundesrepublik Deutschland, 1982-1992. Politik gegen Apartheid?, Opladen: Westdeutscher Verlag. 


\title{
8 The European Union \\ 'European interests', bureaucratic interests and international options
}

\author{
Gorm Rye Olsen
}

\section{Introduction}

The chapter seeks to analyse the Africa policy of the European Community (EC) from its beginnings in the late 1950s up until the first years after September 11, 2001. Here, the term 'EC' is used when references are made to the period prior to 1993 and the term 'EU' for the period following the establishment of the European Union. When referring in general to European cooperation, both terms are used interchangeably.

The chapter has a dual aim. The first is to describe policy changes of the EC/EU towards Africa, and the second to explain the shifts in policy priorities and consequently in policies. The explanation is based on a dual theoretical inspiration. First, it rests on the argument that it is possible to identify special 'European' interests in becoming an international actor and also that there exists such a phenomenon as bureaucratic interests. Second, the explanation leans on the argument that the international environment limits the EC's or, respectively the EU's, policy choices regardless of its ambitions to play a role internationally.

It is the argument of the chapter that the European Africa policy can be explained by a combination of specific 'European interests' and characteristic features of the international environment that change over time. The specific European interests are compounded of two elements, one the old ambition of the European Community to play a role internationally and the other the Commission's bureaucratic interests in maintaining and expanding its area of activity. It is important to emphasize that the two elements are not necessarily in conflict with each other. Moreover, it is necessary to stress that European decision-making related to the aim of becoming a significant international actor is not necessarily an easy and conflict-free process. The difficult decision-making within the EC has to be seen in the light of the fact that European cooperation is a unique phenomenon.

The argument that the international environment is significant in relation to pursuing the ambition of becoming a significant international actor has to do with the observation that the basic features of the international system have changed quite dramatically since the late 1950s. So, the simple 


\section{Gorm Rye Olsen}

assumption is that the possibilities for realizing the ambition of the EU to become a significant international actor depend on the international environment or the international political situation at any given point in time. Depending on the specific period in question, certain policies and policy instruments are the most essential or are simply impossible for the EU to use in its Africa policy.

The chapter is structured as follows. It starts with a brief presentation of the theoretical inspiration guiding the analysis and the explanations offered for the Africa policy of the EC. The empirical analysis begins with a very brief historical overview of the EC's relations with Africa during the Cold War, focusing on the issues of aid. The core analysis deals with the changes in the EU's policies towards sub-Saharan Africa during the post Cold War era. It distinguishes between the periods before and after September 11, 2001. The analysis of the first period deals with the continuation during the 1990s of trade and aid within the framework of the Lomé Conventions, including the different rounds of negotiations tied into this framework of agreements. The analysis of the second scrutinizes the challenges facing the EU because of the increasing number of conflicts in Africa that have appeared in the post Cold War period. The final section analyses the EU's policies towards Africa in the period following the terrorist attack on the World Trade Centre and Pentagon on September 11, 2001.

\section{EU decision-making structures and 'European interests' in Africa}

The EC's unique character - having a number of the characteristics both of a state and of an international organization, but being neither a state nor an international organization - has proved to be a major challenge to International Relations scholars. This analysis takes its starting point in agreement with the argument of Charlotte Bretherton and John Vogler who simply state that 'the EU is an actor sui generis' (Bretherton and Vogler 1999: 44; 248-58). In line with this, Georg Sørensen argues that the EU can be considered as a unique type of state, which he suggests be called a postmodern state (Sørensen 2002).

Because of the unique features of the European Union, EU decisionmaking on Africa and a number of other foreign policy issues involves all the individual member states as well as the common institutions in Brussels. The common institutions include both the European Commission and the Council of Ministers, and to a limited extent the European Parliament. It is possible to argue that EU decisions are the result of bargaining and negotiations that take place on different stages (Moravcsik 1993, 1995). The first stage refers to the bargaining and preference formation that takes place within the individual member states. The second stage refers to the negotiations and bargaining concerning EU issues that involve not only representatives from the member states but also the common institutions in Brussels. 
At the second level i.e. when decision are taken on the supranational level, it is highly likely that a considerable number of conflict areas will appear. On the one hand, there may be conflicts and disagreements between member states, and on the other hand conflict between some member states and other member states together with the common institutions physically located in Brussels. The organizations located in Brussels, in particular the European Commission, may exert little or much influence, depending on the specific policy field and also on its ability to form coalitions with member states (Cafruny and Peters 1998a: $16 \mathrm{ff}$ ). The introduction of the Brussels institutions as active participants in the decision-making processes clearly opens up the possibility that bureaucratic interests (Ravenhill 1985: 33, 36), together with the national interests of the member states, may influence decisions taken in the name of the European Union. Here, it is important to stress that the two stages in the model that is sometimes described by the term liberal intergovernmentalism are not empirically separated. Rather, they are interlinked, implying that decisions formally taken in either of the two stages are the result of influence from and participation by decision-makers located both in the individual member states and in Brussels (Grimm 2003).

Based on this model of preference formation in the European Union, it is possible to elaborate on the idea of 'European interests' that are supposed materialize at the second stage. European interests are assumed to be different from the interests that are articulated in the individual member states, i.e. at the first stage. 'European interests' are basically related to the idea that 'Europe' has a special role to play in the world, based on values such as 'democracy, soft-edged capitalism, a zone of peace among members, and diplomatic mediation between third parties to undercut the causes of major conflict' (Ginsberg 1999: 436; Hill and Wallace 1996: 9). The ambition that the European Community has or ought to play a significant role on the global scene has existed ever since the inauguration of the Community (Cafruny and Peters 1998a: $1 \mathrm{ff}$; Cameron, 1998: 19-44; Bretherton and Vogler 1999).

It is interesting to note that the first tool with which the $\mathrm{EC}$, from the late 1950 s, sought to play a role on the international scene was actually development assistance to Africa (Grilli 1994: 8-11; Lister 1988: 16-20). The formalization of the development cooperation that took place via the Lomé Conventions in the 1970s underlined the fact that the EC as an international actor based its policies on special values such as non-interference and equality (Lister 1988: 79-80; Lister 1997: 109). The end of bipolarity and the subsequent new security environment of the post Cold War era made it clear to many European policy-makers that there was a need for a 'new' European policy that took into account that new challenges faced Europe in the wake of the fall of the Berlin Wall (Schirm 1998: 76; Smith 1996: 250 f; Eliassen 1998: 5). Concretely, the post Cold War situation meant that new policy choices became a real option, which influenced the choice of instruments at hand for the European Union in its policy towards Africa. Among other things, it 


\section{Gorm Rye Olsen}

meant that aid policy became less and less important whereas instruments related to the Common Foreign and Security Policy (CFSP) seemed more relevant.

\section{European-African relations during the Cold War}

From the very start of the EC in 1957, sub-Saharan Africa was the most important region among the poor areas of the world. It manifested itself in the Treaty of Rome, where Article 131 established the association between the Community and the countries and territories in Africa with the aim to "promote the economic and social development of the countries and territories and to establish close relations between them and the Community as a whole' (Grili 1994: 8-11; Lister 1988: 16-20). The combination of trade concessions and aid provisions was carried on in the Yaoundé Conventions (1963-75) and in the Lomé Conventions (1975-2000). During these years, the number of countries participating in aid cooperation with the EC increased from the original 18 in Africa to 68 in Africa, the Caribbean and the Pacific - the so-called ACP countries - that signed Lomé IV (1990-2000) (Grilli 1994: 28).

Lomé introduced a significant innovation via the principle of nonreciprocity in trade between the poor countries and the nine EC member states (Lister 1988: 74-102). The most important feature of the original EC aid may have been that it was intended to be politically and economically neutral (Grilli 1994: 91-136). By the time it was signed, the Lomé construction was widely considered to be a unique example of North-South relations and it was argued that the convention could serve as a model for a new era in North-South relations generally (Lister 1988: 79-8; Lister 1997: 109). However, other factors also played a role in the establishment and continuation of the relationship with Africa. If the European countries wanted to maintain international power and influence, they had to keep close relations with subSaharan Africa, which was one of the traditional areas of influence. For that reason there was criticism that Lomé was actually intended to prevent structural changes in the existing international economic order (Grilli 1994: 335; Lister 1988: 201-3).

There is no doubt that during the late 1970s and the 1980s, the whole concept of association in its original form lost its appeal to the Europeans. This can be explained by a number of circumstances. One was that Africa's position as supplier of raw materials to Europe simply disappeared and with that disappearance, one of the main arguments in favour of the original concept of association lost its rationale (Lister 1997: 109). The rapidly changing international situation, with the obvious weakening of the Communist bloc, also contributed to changing the attitudes of European decision-makers concerning the future of Lomé. These circumstances formed the background to the negotiations on Lomé IV in the last years of the 1980s, i.e. at a time when the Cold War was drawing to an end. 


\section{The post Cold War situation: towards closing Lomé}

It is the aim of this section to show that the altered international situation following the end of the Cold War had some impact on Europe's relations with Africa. The aim is also to show that the actual Africa policy of the EU in this period was to a large extent the result of continuous discussion and bargaining, at stage two, between the European Commission and some member states on the one hand, and other member states on the other.

During the negotiations on the new Lomé Convention IV for 1990 to 2000, the poor countries were lobbying on just one particular issue, namely the size of the financial contribution from the EC. In spite of the fact that the ACPs demanded ECU 15.5 bn for 1990-5, they settled without further ado with the offer of ECU 12 bn by the EC, which represented a minor increase of 4 per cent in current prices over Lomé III. An increase of around 50 per cent was widely reckoned to be necessary to maintain the real value of aid in the face of inflation and increasing ACP populations. It is interesting that the 50 per cent increase was actually favoured by the Commission, whereas a number of member states could not or would not accept an increase of that magnitude (Lister 1997: 112). The EC/EU demanded, and had it written into the new Convention, that it also wanted to have a 'policy dialogue' between the two contracting parties. The principle of policy dialogue was closely related to a number of steps taken towards tightening the conditions for receiving development assistance from the EC.

Taken together, the result of the negotiations in 1989 indicates that relations between the two parties had changed quite dramatically since the start of Lomé in the mid 1970s (Oyewumi 1991; Grilli 1994: 345-6). The moderate financial envelope combined with the successive steps towards tightening the conditions on receiving assistance from the EC can be interpreted as an expression of decreasing European interest in Africa. It was only the Commission, in a more or less obvious alliance with a limited number of member states, that fought strongly for keeping Africa on the development agenda of the EU. There are several possible reasons for the Commission to have adopted this position. One is that the Commission simply expressed the 'European interest' in keeping close relations with Africa, whereas this was not considered a particular strong national interest of most member states. Another explanation is that it was in the institutional interest of the Development Directorate (DG VIII) within the Commission to maintain an aid programme of considerable size.

\section{Promotion of democracy: high profile, low priority}

Shortly after the signing of Lomé IV, a new element came into the relationship between the EC and Africa as prominent European politicians began to link economic development with political freedom and democracy, reflecting new political discourses that emerged immediately after the end of the Cold 


\section{Gorm Rye Olsen}

War. These politicians were quite outspoken about the need to change European development aid policy, stressing that in future it should be difficult for authoritarian governments to obtain development assistance from Europe unless they started democratizing their societies (ODI 1992; Stokke 1995). As early as November 1991, the 12 member states adopted a resolution which stated unequivocally that in future, democracy and respect for human rights would be preconditions for receiving aid from Europe (Council of Ministers 1991). Moreover, the Maastricht Treaty stressed that 'the development and consolidation of democracy and the rule of law and adherence to human rights and fundamental freedoms' ( $\$ 130 \mathrm{U}$, Section 2) are among the important aims of the development policy of the EU. Both the passing of the 1991 Council Decision and incorporation of Article 130U are clear examples of the influence of national politicians on the common policies of the EU towards the poor countries.

In spite of the fact that promotion of democracy and human rights abroad was indisputably a high-profile issue in Europe's external relations throughout the 1990s, it is all the more interesting that the budget line called 'Governance and civil society' was so limited (Cox and Koning 1997: 40; Crawford 2001: 237). In the same line, it is also worth noting that the implementation of the policy was characterized by a lack of consistency and a general lack of correlation between the degree of human rights violations and the level of sanctions imposed by the EU (Crawford 2001: $178 \mathrm{f}, 209-27,231 \mathrm{ff}$ ). The flawed implementation of this high-profile policy underlines two things, at least. One is that the new international situation after the end of the Cold War indeed opened the way for new policy initiatives. Second, the democracypromotion initiative illustrates that when it came to actual policy and not just declarations, there was a considerable gap between declarations and implementation of Community policy. The latter can be interpreted as a general lack of substantial interest in the democracy-promotion issue at least in relation to Africa.

\section{The 1995 mid-term review}

Disagreements appeared quite openly between some national decisionmakers and decision-makers in Brussels both within the Commission and in the Council of Ministers during the mid-term review of Lomé IV that took place in 1995. The disagreements showed a pattern that continued to characterize the relationship between the EC and Africa in the years that followed. The pattern reflected disagreement between on the one hand some national governments who were reluctant to continue to finance the close relationship with Africa and, on the other hand, the Commission in coalition with some member states, who fought to maintain a reasonably favourable relationship with Africa.

Before the first half of Lomé IV expired in February 1995, it was clear that the Convention had not worked well, and neither the EU nor the ACP 
countries were satisfied. This supplied the critical governments with ammunition against the common aid programme (personal interviews, Brussels, January 1995; Bossuyt et al. 1993). An old but crucial complaint concerning the effectiveness of the common aid programme was articulated. For a number of years frustration had been increasing because of the lack of positive results after so many years of development assistance to Africa. Some member states, especially Germany and the UK, were particularly critical of the EU common aid programme because several studies had shown integrated rural development and livestock projects to be unsuccessful, including a number of direct disasters (Riddell 1993: $62 \mathrm{ff}$ ).

To make things worse, only half of the total sum of ECU 12 bn had been spent by the end of the first five-year period (1990-5). One explanation was the lack of sufficient absorptive capacity due to inefficiencies in the administrative apparatus of the recipient countries. Another was that the EU aid programme lacked coordination with the bilateral programmes and that the procedures for disbursing EU aid were both slow and excessively bureaucratic, to the extent that the Commission's activities were mainly 'a set of ad hoc piecemeal responses to unfolding events' (Grilli 1994: 350ff; Box and Goodison 1994).

It was in this general atmosphere of disillusion and critique that the midterm negotiations on the second five-year period of Lomé IV (1995-2000) took place. The negotiations made slow progress, mainly because of the strong disagreements that existed among the EU member states. Despite the fact that the European Commission proposed a financial protocol for the years 1995-2000 that merely covered inflation, a number of member states wanted a much smaller financial aid package. They demanded a reduction in the Commission's proposal that was so problematic as seen from the point of view of the French chairman of the Council of Ministers, Alain Juppé, that he broke off negotiations in February 1995. He argued that he had to do so because he would certainly not propose an 'insulting' offer to the ACP countries that were already assembled in Brussels ready to sign the new agreement (Guardian, 17 February 1995; International Herald Tribune, 17 February 1995).

It took more than four months of internal EU negotiations to reach agreement among the member states on a proposal to present to the ACP countries. To reach this point, involvement of the presidents of France and Germany as well as of the British prime minister was required. Finally, at the EU summit in Cannes in June 1995 the EU heads of state and government agreed to release ECU 12.8 bn for the years 1995-2000 (Conclusions 1995). The figure was a slight improvement compared with the figures that caused Juppé so much embarrassment four months earlier but considerably less than the ECU 14 bn that would have compensated for inflation.

The Cannes summit was significant for another reason, too. The summit made it clear that the geographical priorities of the EU were changing quite dramatically from sub-Saharan Africa towards North Africa and the Middle 


\section{Gorm Rye Olsen}

East. While there was a considerable reluctance to finance the second half of Lomé, the European politicians assembled in Cannes decided to allocate ECU 4.7 bn to the Mediterranean region for the years 1995-2000. The aid package was tantamount to a situation where the EU per capita aid to the Mediterranean countries became the same size as the per capita aid to Africa south of the Sahara (Ministry of Foreign Affairs 1996: 140). Moreover, at the subsequent historical summit in Barcelona in November 1995, the EU offered to gradually develop a free-trade zone between the 15 EU countries and the 12 poor countries south and east of the Mediterranean before the year 2010. Gordon Crawford summarizes the result of the mid-term review by emphasizing that the fall in the real value of the aid funds combined with the number of political conditions and control initiatives indicated 'a declining [EU] commitment to the ACP group, particularly in contrast with the growing volume to other regions' (Crawford 1996: 504). He maintains that 'the outcome of the mid-term review . . . signals that the Convention itself is under threat, with growing doubts about its future after expiry of the current agreement' (ibid.: 503-4).

Based on the analysis of the negotiations mid-term review on Lomé IV, it is possible to come to specific conclusion and draw attention to one important fact. Without the efforts by the EU expressed most clearly by the Commission but also by the work of the French chairman of the Council of Ministers, Lomé IV would have been much less favourable to the poor countries. It is possible to argue that the institutions in Brussels defended or expressed a 'European' interest. However, it is also possible to claim that the Commission in particular defended its own institutional interests, even though it might have been presented as a 'European' interest to maintain the Lomé cooperation. It is necessary to state the fact that even though an agreement between the EU and the poor countries was signed in Cannes, disagreements continued to exist between a number of member states on the one hand and the Commission and some member states on the other hand. These disagreements probably explain radical changes of the Lomé concept were necessary and also that future changes would point towards a Convention that would be much less sensitive to the development concerns of the ACPs (Arts and Byron 1997; Lister 1997: 136-42).

\section{Negotiating Lomé V - post 2000}

It is the aim of this section to show how the continued tension between the European interests, the interests of the common institutions and the interests of the member states influenced the negotiations on the Lomé $\mathrm{V}$ and thereby produced some very clear limitations on how favourable a new convention would be to the poor countries. The European commitment to bring about radical changes of the EU-ACP relationship manifested itself soon after the conclusion of the mid-term review, when in late 1996 the Commission published a so-called 'Green Paper' discussing the future relationship between 
the EU and the ACP countries (Commission 1996). It became clear that the Commission preferred one particular option that entailed that the ACP group would be split into a number of regional and sub-regional units (Lister 1998: 375-90). There is no doubt that the position of the Commission was inspired by the negations that took place within the World Trade Organisation (WTO) on the need for free trade. Therefore, it is not surprising that the Commission's negotiating mandate for a new Convention contained a proposal to replace the existing non-reciprocal trade preferences with free-trade arrangements under the heading of 'Regional Economic Partnership Agreements' (REPAs) to be signed with different ACP regions and countries (Council 1998).

It is beyond dispute that the EU's proposal for a revised trade component of Lomé V (Cotonou) was a radical break with the past. Also, the offer of a financial protocol for the Cotonou Agreement was illustrative of the European attitude towards the ACP countries at the end of the 1990s. The EU Commission offered ECU 14.33 bn, which was only just enough to keep up with the inflation over the past five years. Several EU states would not even accept the moderate financial proposal of the Commission and demanded additional reductions. The EU member states finally agreed to offer the ACP countries ECU 13.8 bn (Financial Times, 10 December 1999 and interviews, Brussels 1999).

Like its predecessor, the non-financial elements of the Cotonou Agreement represented an additional step towards tightening the conditionalities for receiving assistance from the EU. Anti-corruption measures were given high priority, along with the issues of good governance and 'political dialogue' either with individual developing countries or with regional groupings already contained in second Lomé IV. Compared with Lomé IV, a totally new element came into the Cotonou Agreement, namely the possibility of suspending aid cooperation with a developing country if the level of corruption became excessive. Another new element in the Agreement may be even more conspicuous, namely Article 13 dealing with the politically highly sensitive issue of immigration. Article 13 explicitly states that 'each of the ACP States shall accept the return of and readmission of any of its nationals who are illegally present on the territory of a member State of the European Union'.

The inclusion of immigration in the Cotonou Agreement was a clear expression of the political significance attached to this issue by the member states in the wake of the fall of the Berlin Wall. It was also stressed by the fact that the Amsterdam Treaty, which came into force in May 1999, openly declared that a common immigration policy was a clear priority of the EU (Lavenex 2001: 851, 868). The aim of establishing a common immigration policy and the inclusion of the issue in the Cotonou Agreement highlight the increasingly stronger trend within the EU to integrate development issues into broader foreign policy priorities.

In conclusion, both the negotiating process leading to the final agreement and the outcome itself, i.e. the Cotonou Agreement, underlined that the 


\section{Gorm Rye Olsen}

majority of the EU member states had lost interest and/or confidence in aid and trade as instruments in an African context. Thus Marjorie Lister finds that the Europeans have 'lost their confidence in the West's ability to develop other regions' and argued that the EU has 'drifted into a state of confusion somewhere between improving its development policy and losing hope' (Lister 1998: 377).

Nevertheless, the new Cotonou Agreement was signed in June 2000. It is difficult to understand that fact unless it is accepted that the Commission in coalition with other decision-makers, i.e. a number of member states, worked in favour of a new Convention. Moreover, it has to be accepted that these actors had quite substantial influence on the position of the EU in its negotiations with the ACP countries. The lobbying by the Commission and its allies in this particular situation has to be explained either by reference to the existence of a common understanding of what are 'European' interests in this particular issue, or by the strength of the institutional interests of the Commission and its ability to form alliances. Irrespective of which explanation is the most convincing, there is no doubt that the understanding of European interests in some kind of relationship with the ACP countries changed quite significantly during the 1990s.

\section{Africa and the development of a European foreign policy}

During the 1990s, it increasingly became an EU policy priority to manage or contain the growing number of violent conflicts in Africa. The new explicit focus on conflict and security issues coincided with the clearly growing concern about immigration, which as already mentioned had become a very hot political issue. This section aims to show that the focus on security issues became stronger during the decade preceding September 11, 2001 and that this new policy priority was intimately interwoven with the old EC ambition to become a significant international actor. Here it is highly relevant to draw attention to Christopher Hill's old argument that 'defence is the key to the development of the Community's place in the world' (Hill 1993: 318). Because the EU as a so-called post-modern state has overcome the military threats from individual member states, in the post Cold War era it is mainly exposed to conventional security threats from modern states and to turmoil in weak postcolonial states, for example in Africa, so Georg Sørensen argues (Sørensen 2001: $129 \mathrm{ff}$ ). Moreover, general instability and civil unrest tend to produce emigration both nationally and internationally. It is possible to claim that the EU as a post-modern state has a special interest in meeting such soft threats because they in particular threaten the identity (Buzan 1991: 122-3) of the EU or the European nationhood that as yet remains so undefined. Faced with such threats, it appears as if traditional development issues lost their significance as determinants of the EU's Africa policy and therefore that development assistance tended to lose its importance as a policy instrument vis-à-vis Africa. 
The focus on conflicts and conflict prevention in Africa can be traced back to 1993, when the EU Commission launched its first initiative on 'Peacebuilding, conflict prevention and resolution in Africa' (Landgraf 1998: 103). It was followed by a number of declarations stressing that the Union was concerned about the rising number of violent conflicts on the African continent. The EU summit at Essen in December 1994 called for an 'intensive political dialogue between the EU and OAU, in particular regarding conflict prevention in Africa' (Landgraf 1998: 103). The same opinion was expressed in the final document from the EU summit at Madrid in December 1995 (Conclusions 1995). In 1996, the European Commission issued a 'communication' on conflict and conflict prevention, stressing that the use of development aid and related instruments were considered to be important to the EU. In June 1997, a 'Common Position' on these questions was issued making it clear that conflict prevention was an EU priority (Landgraf 1998: 110). By the end of the decade, the Commissioner for Development Aid, João de Deus Pinheiro, declared that Africa had become a special concern of the EU because of the disturbing number of violent conflicts there (Pinheiro 1999).

In spite of the reluctance of many member states to give too much power to the CFSP (Rhodes 1998: 1-17; Cafruny and Peters 1998b: 299), the Maastricht Treaty nevertheless introduced the system of 'joint actions' as a new element in European foreign policy-making, opening up scope for closer co-operation in foreign policy (Piening 1997: 40-2). The joint actions are clearly related to the ambition to develop the EU into a significant international actor. In this context, it is important to note that one of the first five joint actions decided upon in 1993 - and the only out-of-area action - was actually directed towards Africa, namely towards South Africa. Martin Holland argues that this particular joint action is interesting because it 'offered an opportunity for the new Union to express its global role' (Holland 1997: 174).

The genocide in Rwanda in 1994 was an extremely frustrating experience for the EU. Because of the dubious role of France during the genocide, the Union had to issue a number of statements expressing 'deep concern' and 'dismay' over the situation (European Foreign Policy 1994). The genocide gave an additional push to EU debates on how to prevent a recurrence of such tragedies. As one important step towards serious involvement in conflict prevention in the Great Lakes Region, on 25 March 1996 the EU Council of Ministers agreed on a Joint Action, appointing a Special Envoy, Mr Aldo Ajello, in 'order to help the countries in the region to resolve the crisis affecting them' (Council 1996). Moreover, the mandate stressed that $\mathrm{Mr}$ Ajello 'where appropriate [should] establish contact with other prominent figures and parties who might have a role to play in settling the conflicts in the region' (Council 2001). One important aim of the appointment of the special envoy was no doubt to give the EU visibility in the region and thereby in the world (confidential interviews, 


\section{Gorm Rye Olsen}

Brussels January 2002). In that sense, the joint action appointing Ajello was clearly one element in the strategy to develop the EU into a significant international actor.

The CFSP towards Africa consisted of both Joint Actions and 'Common Positions' (joint policy declarations) of the European Council. For example the Council adopted a Common Position on 8 November 1999 expressing the EU's support for the implementation of the Lusaka ceasefire agreement in the peace process in the DRC. In Article 1 of the Common Position, it was stressed that once peace was restored, the EU was ready to 'consider long-term cooperation in support of national reconstruction' (Council 1999). In a Common Position of 19 June 2000 the Union strongly deplored the resumption of the civil war in Angola and called for a political solution to bring a lasting peace to the country (Council 2000). Moreover, the EU declared its readiness to consider how to assist the government of Angola, which was facing huge challenges in rebuilding and reconstructing the country (Council 2000). In line with this, the Council adopted a Common Position on the prohibition of imports of rough diamonds from Sierra Leone. The aim was to promote a ceasefire as the rebels started having difficulties financing the war. Finally, the EU adopted no less than five Common Positions on the conflict between Ethiopia and Eritrea during 1999 and 2000, stressing the serious concerns of the Europeans.

The increasing significance of general foreign and security concerns was explicitly articulated in 2000 by the Portuguese Presidency in its 'Reflection paper' concerning the EU's future relations with Africa. The paper stressed that 'development priorities should be thought of in the context of ongoing dynamics, namely those related to the reorganization of external relations [in the Commission] and the building of a European CFSP. Being realistic about development means thinking in an integrated manner about politics, security, and trade as well as development aid itself' (Cardoso et al. 2000). The wish to see Africa as a crucial element in the Union's general international relations naturally led to the first European-Africa summit in Cairo in early April 2000.

In summary, the growth in the number of conflicts in Africa was hardly a threat to the national interests of individual European member states. However, this does not exclude the possibility that the EU as an international actor could have an interest in managing and preventing conflicts in Africa, even though it is more appropriate to describe this particular European interest as a 'derived interest' because it is not necessarily tied directly to preventing conflicts per se. It is a derived interest as far as intervening in these conflicts primarily serves to emphasize that the EU is an actor on the global scene as a conflict manager and not just as a big aid donor. At the same time, it cannot be denied that segments within the Commission and within the development administration developed institutional interests in pushing the issue of conflict prevention and presenting it as a European interest. 


\section{EU-African relations after September 11, 2001}

The terrorist attacks on the World Trade Centre and the Pentagon represented a welcome opportunity for the EU to present itself as a significant global actor by virtue of both its strong condemnation and the concrete policy steps initiated as a consequence of these misdeeds. In the six months following September 11, the EU and the US worked intensively on joint initiatives designed to counter and defeat international terrorism. The EU confirmed its staunch support for the military operations that in Afghanistan began on 7 October 2001, in agreement with the resolution of the UN Security Council. Also, the EU strengthened its diplomatic efforts, initiating a number of bilateral and regional initiatives that included the Middle East.

The Union's policies towards Africa after September 11 were mainly limited to a number of declarations condemning terrorism but without changing the basic features of the existing policies. Thus, at the first Europe-Africa Ministerial meeting that took place as part of the Cairo process in Brussels on 11 October 2001, the discussions were strongly influenced by the terrorist attacks, with the item 'Fight against Terrorism' having been added to the agenda. As a consequence of the debate, the ministers agreed a Joint Declaration on terrorism (Background note, 2001, annex II). At the second Ministerial meeting held in Ouagadougou on 28 November 2002, also within the framework of the EU-African dialogue, the ministers once again adopted a Joint Africa-Europe Declaration on terrorism, reiterating their commitment to fighting international terrorism and condemning all acts of terrorism (Council, Doc. 15197/02). The strong denouncement at the Ouagadougou meeting may have to be seen against the background of the terrorist act in Mombassa on the very morning of the meeting.

Interestingly, only a few months after September 11 the EU Commissioner for Development Assistance, Poul Nielson, maintained that the attack on the US would not have any influence on the volume of EC aid. Moreover, $\mathrm{Mr}$ Nielsen stressed that there was no need for additional money for the EU system and he maintained that he did not feel under pressure to dip into the development funds for security purposes or for political rewards to friendly minded countries (DT 14/01: 2). Nevertheless, shortly after the statement was issued by the Commissioner, the ministers responsible for aid in the EU member states agreed to a joint target of 0.7 per cent of GDP in development aid. In her remarks at the meeting, the Swedish minister for aid, Maj-Inger Klingval, said that after September 11 it was necessary not only to create 'a global coalition against terrorism. We need a global coalition against poverty as well' (DT 17-18/01: 2). However, the timetable for increasing the EU members' aid was not fixed at the meeting but postponed to be agreed with the European Commission. But at the European summit in Barcelona in March 2002, the 15 member states promised to make an effort to set aside at least 0.33 per cent of their individual GDPs for ODA by 2006 (Council 2002a). 


\section{Gorm Rye Olsen}

This decision basically meant that it would take a number of years before the pledges to increase the aid of the EU would materialize.

In summary, September 11 meant that the EU and the African countries issued a number of joint declarations dissociating themselves from terrorism. On the face of it, the joint determination to fight terrorism in Africa too did not lead to increases in the volume of development aid. On the contrary, the downward trend in international aid to Africa since the 1990s seems to have continued after September 11. Therefore, if the pledges to increase European aid are actually implemented in the future, the increased aid will hardly reach Africa. On the contrary, the changes during the last decade of the twentieth century indicate that to the EU, Africa is primarily a security issue and only secondarily an issue of development. The terrorist attacks on the US seem only to have confirmed that evaluation, as it is possible to argue that the decision on 5 June 2003 to deploy an EU-led military stabilization force in the Ituri province in North Eastern DRC underlines that Africa is increasingly considered as a security issue for the EU (Council 2003).

\section{Conclusions}

The analysis in this chapter has built on the basic assumption that the Africa policy of the EC and its changes from the late 1950s until 2003 can be explained by a combination of domestic political struggles within the EC or the EU and the opportunities that the changing international environment of this period of time offered. The analysis has shown that the ending of bipolarity gave the EU much greater opportunities for realizing its old ambition to become a significant actor on the international scene. The development of a common foreign and security policy was considered to be a crucial element in the post Cold War strategy to give the EU an international identity, as it was stated in both the Union treaty and the Amsterdam Treaty. However, the analysis also showed that internal disagreements, on the one hand between member states and on the other hand between member states and the European Commission, have had a considerable impact on the policy initiatives directed towards Africa.

The analysis established that Africa has played a role, even though it may very well have been a minor one, within the framework of the efforts to establish the Union as an international actor with a CFSP. Nevertheless, during the 1990s, Brussels issued a number of Joint Actions and Common Positions expressing the common policy positions of the Union's member states. Also, the EU made a number of concrete policy initiatives, such as appointing Mr Aldo Ajello the EU's special envoy to the Great Lakes Region and the deployment of the EU force in the Ituri province of the DRC.

It is worth noting that in parallel with the increasing attention given to security and foreign policy issues in Africa in the post Cold War period, the traditional policy instrument of the EU, namely development assistance, lost much of its importance as measured not only by the drastically reduced 
volume but also in relative terms; Africa lost vis-à-vis other geographical regions such as the Middle East. This separate course of development can be explained by the increasing opposition from a number of important member states which have been strongly against giving large amounts of development assistance in particular to Africa south of the Sahara. One of the important findings in this chapter is precisely that the effective lobbying of the Commission in collaboration with a limited number of member states can explain why the decisions taken at stage two, i.e. in Brussels, were able to prevent that the Union's development aid from being reduced to a much greater extent. Based on that observation, it can be argued that the Commission has been one of the most important institutions to articulate and defend EU interests vis-à-vis Africa. In the post Cold War era, and even more so in the period following September 11, it is possible to maintain that the Commission, in coalition with some member states, has argued that an increased focus on conflict-preventing measures is a European interest, given the new international situation. This conclusion is not necessarily in opposition to another conclusion that maintains that the by launching a strong defence of 'European interests' in Africa, the Commission has secured its own institutional interests in having a special European development programme that increasingly combines this programme with a CFSP approach to sub-Saharan Africa.

\section{References}

Arts, K. and Byron J. (1997) 'The Mid-term Review of the Lomé IV Convention: Heralding the Future?', Third World Quarterly, Vol. 18, No. 1, pp. 73-91.

Bossuyt, J., Laporte, G. and Brigaldino, G. (1993) European Development Policy After the Treaty of Maastricht: The Mid-term Review of Lomé IV and the Complementarity Debate, Maastricht: ECDPM.

Box, L. and Goodison, P. (1994) 'Coordinate or be Coordinated: Europe-ACP Development policies from a Maastricht Perspective', in J. L. Rhi-Sausi and M. Dassù (eds), Coordinating the Development Aid Policies of European Countries, Rome: Centro Studi di Politica Internazionale, Vol. II.

Bretherton, C. and Vogler, J. (1999) The European Union as a Global Actor, London and New York: Routledge.

Buzan, B. (1991) People, States and Fear, London: Harvester Wheatsheaf.

Cafruny, A. and Peters, P. (1998a) 'EU Foreign Policy: From Maastricht to Amsterdam', in A. Cafruny and P. Peters (eds), The Union and the World: Economy of a Common European Foreign Policy, pp. 1-10, The Hague: Kluwer Law International.

_ (1998b) 'Towards a European Foreign Policy? Evidence from the Case Studies and Implications for the Next Decade', in A. Cafruny and P. Peters (eds), The Union and the World: Economy of a Common European Foreign Policy, pp. 209-304, The Hague: Kluwer Law International.

Cameron, F. (1998) 'The European Union as a Global Actor: Far from Pushing its Political Weight Around', in C. Rhodes (ed.), The European Union in the World Community, pp. 19-44, Boulder: Lynne Rienner. 


\section{Gorm Rye Olsen}

Cardoso, F. J., Khüne, W. and Honwana, J. B. (2000) Reflection paper. Priorities in EU Development Cooperation in Africa: Beyond 2000, Bruxelles: Council of Ministers (Fax as of 26.01.00).

Commission (1996) The European Commission, DGVIII, Green Paper on Relations Between the European Union and the ACP Countries on the Eve of the 21st Century. Challenges and Options for a New Partnership, Brussels, 14 November.

Conclusions (1995) The Conclusions of the Presidency. The European Summit, Madrid, 15-16 December 1995.

Council (1996) Council of the European Union, 'Council decision on the nomination of a Special Envoy for the African Great Lakes region', Joint Action 96/250/CFSP, Brussels, 25 March 1996.

Council (1998) Negotiation Directives for the Negotiations of a Development Partnership Agreement with the ACP Countries, Bruxelles: The European Union, 30 June.

Council of Ministers (1991) 'Communication to the Press', Res. No. 10107, Brussels, 28 November.

Council of Ministers (2003) Adoption by the Council of the Joint Action on the European Union Military Operation in the Democratic Republic of Congo (DRC), Brussels, 5 June, 9957/03 (Presse 156).

Cox, A. and Koning, A. (1997) Understanding European Community Aid. Aid Policies, Management and Distribution Explained, London: Overseas Development Institute.

Crawford, G. (2001) Foreign Aid and Political Reform. A Comparative Analysis of Democracy Assistance and Political Conditionality, Houndmills: Palgrave.

_ (1996) 'Whither Lomé? The Mid-term Review and the Decline of Partnership', The Journal of Modern African Studies, Vol. 34, No. 3, pp. 00-00.

Eliassen, K. (1998) 'Introduction: The New European Foreign and Security Policy Agenda', in K. Eliassen (ed.), Foreign and Security Policy in the European Union, pp. 1-8, London: Sage Publications.

European Foreign Policy Bulletin Database, Rwanda, Doc. 94/136 (12 April 1994), ibid., Rwanda Doc. 94/169 (5 May 1994), ibid., Rwanda Doc. 94/255 (24 October 1994).

Ginsberg, R. (1999) 'Conceptualising the European Union as an International Actor: Narrowing the Theoretical Capability-Expectations Gap', Journal of Common Market Studies, Vol. 37, No. 3, pp. 429-54.

Grimm, S. (2003) Die Afrikapolitik der Europäischen Union. Europas aussenpolitische Rolle in einer randständigen Region, Hamburg: Institut für Afrika-Kunde.

Grilli, E. (1994) The European Community and the Developing Countries, Cambridge: Cambridge University Press.

Grilli, E. and Riess, M. (1992) 'EC Aid to Associated Countries: Distribution and Determinants', Weltwirtschaftliches Archiv, Band 128, heft 2, pp. 202-20.

Hill, C. (1993) 'The Capability-Expectations Gap, or Conceptualizing Europe's International Role', The Journal of Common Market Studies, 31, 3, 305-25.

Hill, C. and Wallace, W. (1996) 'Introduction: Actors and Actions', in C. Hill (ed.), The Actors in Europe's Foreign Policy, Routledge: London and New York, pp. 1-16.

Holland, M. (1997) 'The Joint Action on South Africa: A Successful Experiment?', in M. Holland (ed.), Common Foreign and Security Policy. Record and Reforms, pp. 174-83, London: Pinter.

Landgraf, M. (1998) 'Peace-building and Conflict Prevention in Africa: A View from the European Commission', in U. Engel and A. Mehler (eds), Gewaltsame Konflikte und ihre Prävention in Afrika, pp. 103-17, Hamburg: Institut für Afrika-Kunde. 
Lavenex, S. (2001) 'The Europeanization of Refugee Policies: Normative Challenges and Institutional Legacies', Journal of Common Market Studies, 39, 5, 851-74.

Lister, M. (1998) 'The European Union's Green Paper on Relations with African, Caribbean and Pacific Countries', Oxford Development Studies, 26, 3, 375-90.

(1997) The European Union and the South. Relations with Developing Countries, London: Routledge.

(1988) The European Community and the Developing World, Aldershot: Avebury.

Ministry of Foreign Affairs (1996) Strategies for Individual Organizations. Annex to the Plan of Action for Active Multilateralism, Copenhagen: Ministry of Foreign Affairs.

Moravscik, G. (1993) 'Preference and Power in the European Community: A Liberal Intergovernmentalist Approach', Journal of Common Market Studies, Vol. 31, No. 4, pp. 473-524.

Moravscik, G. (1995) 'Liberal Intergovernmentalism and Integration: A Rejoinder', Journal of Common Market Studies, Vol. 33, No. 4, pp. 611-28.

ODI (Overseas Development Institute) (1992) Aid and Political Reform, Briefing Paper, January, London.

Oyewumi, A. (1991) 'The Lomé Convention: From Partnership to Paternalism', The Round Table, No. 318.

Piening, C. (1997) Global Europe. The European Union in World Affairs, Boulder, CO: Lynne Rienner.

Pinheiro, J. de D. (1999) Peace-Building and Conflict Prevention in Africa, Brussels: European Commission, Directorate General for Development.

Ravenhill, J. (1985) Collective Clientelism. The Lomé Conventions and North-South Relations, New York: Columbia University Press.

Rhodes, C. (1998) 'Introduction: The Identity of the European Union in International Affairs', in C. Rhodes (ed.), The European Union in the World Community, pp. 1-17, Boulder, CO: Lynne Rienner.

Riddell, R. (1993) 'European Aid to Sub-Saharan Africa: Performance in the 1980s and Future Prospects', The European Journal of Development Research, Vol. 4, No. 1, pp. 59-80.

Schirm, S. A. (1998) 'Europe's Common Foreign and Security Policy: The Politics of Necessity, Viability and Adequacy', in C. Rhodes (ed.), The European Union in the World Community, pp. 65-82, Boulder: Lynne Rienner.

Smith, M. (1996) 'The EU as an International Actor', in J. Richardson (ed.), European Union Power and Policy-Making, pp. 247-62, London and New York: Routledge.

Sørensen, G. (2001) Changes in Statehood. The Transformations of International Relations, Houndmills: Palgrave.

\section{Journals and newspapers}

Financial Times, London.

The Guardian, London.

International Herald Tribune, Amsterdam.

Le Monde, Paris. 


\title{
9 The United Nations A peripheral organization on
the periphery of the world
}

\author{
Gorm Rye Olsen
}

\section{Introduction}

Towards the end of the last century, Kofi Annan, the United Nations Secretary General, said that the Security Council was now spending 60 per cent of its time on Africa (Shawcross 2000: $23 \mathrm{ff}$ ). It was not without good reason that the General Secretary made his statement. In Angola, the UN peacekeeping process had collapsed and an all-out war began in late December 1998, bringing the country towards the brink of another disaster.

However, Angola was not the only African country that was at war in the late 1990s. For several months, a large number of countries had been fighting in the DRC, defending or attacking the regime of President Laurent Kabila and leading to its popular name, 'Africa's Great War'. In Sudan the UN continued to co-ordinate 'Operation Lifeline', a relief operation for the starving victims of the Sudanese civil war. It cost $\$ 1$ million a day to fly in 17,000 tons of food (ibid.: 24). To the east, there was a border war between Eritrea and Ethiopia. To the west, in Sierra Leone one of the most horrible civil wars confronting the Secretary General was dragging on. The rebels known as the Revolutionary United Front (RUF) under the leadership of Foday Sankoh attacked the ineffective and corrupt government in Freetown.

Thus, sub-Saharan Africa became a main area of concern for the UN due to the alarming number of wars and civil wars that ravaged the continent in the post Cold War period. Closely related to the widespread instability and killing, millions of Africans fled their home regions. As a matter of fact, subSaharan Africa was the region of the world that contained most refugees and internally displaced persons in relation to the total number of inhabitants. On top of these very pressing problems, the economic and social situation on the African continent was at best bleak, with an average GDI per capita that was lower than it was 30 years ago (World Bank 2000).

It is the argument of this chapter that because Africa has had and continues to have such a low priority on the foreign policy agenda of the leading powers in the world, the UN's role on the continent has been quite limited. This low priority has mainly manifested itself in steadily dwindling resources to the organization since the early 1970s. The conspicuous growth 
in peacekeeping operations in Africa in the post Cold War period in no way undermines the general argument that Africa is of very limited importance to the leading powers. On the contrary, it confirms the reluctance of the great powers to engage in Africa. Instead of engaging strongly by deploying Western soldiers, the leading powers have preferred to let the UN take care of problems in Africa that 'had to be dealt with'.

The structure of the chapter is as follows. First there is a brief presentation of different theoretical interpretations of the $\mathrm{UN}$ and the possibilities for it to play a role within selected policy fields. The first policy area to be analysed here is the UN's policy on promoting peace and stability in sub-Saharan Africa. The second area is the efforts of the world organization to promote economic and social development. Third, the policy on humanitarian assistance and in particular the efforts related to refugees and internally displaced persons will be analysed.

\section{Perceptions of the United Nations}

The UN is the core example of an intergovernmental organization (IGO) that may be defined as 'the more concrete manifestation of regularized international relations with formal and material existence separate from, though for the most part dependent on, states and groups within states' (Archer 2003: 2). Over the years, the studies of IGOs such as the UN have changed quite considerably. In the first half of the twentieth century, academic studies typically focused on the institutional framework and norms of IGOs in order to explain their role and behaviour in international relations. During the Cold War, scholarly research shifted towards trying to understand the duality between the interests of the nation states and the idea that IGOs could potentially also become important actors in their own right, even though states were the principal members (Pease 2003: $3 \mathrm{ff}$ ).

From the middle of the 1980s the study of international organizations saw an explosion in analyses of what were called international regimes (Hasenclever, Mayer and Rittberger, 1997). An international regime can be defined briefly as 'a set of implicit or explicit principles, norms rules and decision-making around which actors' expectations converge in a given issue area' (Krasner 1983: 2). Regime studies tend to focus on a narrow policy field, such as environmental policy or trade, etc., and not on what is the general purpose of the UN. One of the strengths of regime analysis is the intention to include other actors beyond states and IGOs, such as nongovernmental organizations (NGOs), multinational corporations and even individuals (Pease 2003: 4).

The different approaches to and perspectives on the IGOs also indicate that such studies are based on different theoretical foundations. Bøås and McNeil claim that it is necessary to speak of just two models when analysing multilateral institutions, namely the rationalist and the critical approaches (Bøås and McNeil 2003). Clive Archer suggests that it is suitable to use the headlines 


\section{Gorm Rye Olsen}

of realist, reformist and radical international relations thinking in order to group the different interpretations of what are the potential roles and also the limitations of the UN in international politics (Archer 2003: 112-73). Realist and neo-realist scholars do not leave much room for international organizations. Because the realist approach is so state-centric, it maintains that, to a large extent, the narrow interests of the strongest state(s) determine the policy of an intergovernmental organization like the UN. The approach tends to reduce the UN to an instrument of the strongest states, which automatically ascribes limited independent room for manoeuvre to the organization. The neo-realists suggest that it is often adequate to distinguish between 'low politics' (economic and social policies) and 'high politics' (security policy, etc.). Using this distinction, it is possible to claim that, irrespective of the specific policy issue, Africa is basically 'low politics' for the strong states.

Under the headline of reformist or liberal approaches, no doubt the most prominent is the interdependency theory, which is also the best-known (Archer 2003: 127-51). Interdependency theory maintains that there are a number of other actors but the nation states are relevant when it comes to studying IGOs. Because the world is characterized by complex interdependency, international actors such as NGOs, multinational corporations and also individuals and even ideas are just as important as states when it comes to influencing international changes.

Finally, the radical approaches cover a broad range of positions stretching from Marxist views, Third-World positions and so-called critical theories (ibid.: 151-72). They all share a critical or at least sceptical view of international organizations and of the potential positive role that such organizations may play. Their scepticism towards IGOs seems to be based on an observation that because these organizations simply reflect the existing international power relations or because they are not particularly helpful in changing an unequal and exploitative world order, they are not important.

These different theoretical frameworks call attention to the different functions or roles that the UN may fulfil (Archer 2003: 91). Thus, at times the UN has played the role of being an instrument of the strongest powers or the strongest state in the international system, which is exactly the understanding in realist thinking. In the first eight years of its existence, the world organization was to a large extent an instrument of US diplomacy (Archer 2003: $68 \mathrm{ff}$ ). However, such a role could not be sustained once the membership of the General Assembly increased due to the decolonization process in the late 1950s and early 1960s, and when the Cold War became more intense. In particular, when the developing countries began to use the UN as an instrument for implementing their foreign policies priorities, the US became increasingly sceptical about the organization.

It is also possible to argue that the UN can play a second role, namely an arena or a forum for the members where they can meet, debate, argue, co-operate, or disagree (Archer 2003: $73 \mathrm{ff}$ ). The role of the UN as an arena for the states of the world became particularly prominent during the 1960s 
and 1970s. During these two decades, developing countries in particular used the UN General Assembly and the UN agencies to air their views on the need for a fundamental restructuring of the international system under the headline of a New International Economic Order (NIEO) (Murphy 1997: 206-12; Groom, 2003: $128 \mathrm{ff}$; Taylor 1993: $142 \mathrm{ff}$ ).

Finally, the UN can also play a third role, namely that of an independent actor where the crucial word is 'independent' (Archer 2003: $79 \mathrm{ff}$ ). The independent role of the world organization was particularly pronounced from the mid 1950s and the following years, this being the era when the peacekeeping operations of the UN emerged. The concept of peacekeeping was closely linked with the ideas of 'preventive diplomacy' of the UN's second Secretary General, Dag Hammarskjold. He considered it part of the task of the UN Secretariat to help stabilize areas of conflict so that parties might be brought together in order to negotiate or just simply talk (Archer 2003: 84). The first major military operation of the UN was the Emergency Force imposed between Egyptian and Israeli forces to allow the withdrawal of British and French troops from the Suez Canal during the crisis in November 1956. The growth of peacekeeping operations allowed the institutions of the $\mathrm{UN}$ and the Secretariat in particular to play an active and independent role.

In summary, the UN may play different roles and perform different functions. If a realist or neo-realist interpretation is applied, the UN in general will be expected to be of minor importance in relation to the stronger states. At best, powerful states can use the UN to support or even to pursue their policies. This is almost the opposite interpretation found in liberal approaches, which attribute a considerable independent role to the UN. In principle, this interpretation holds that the UN may play a role in line with the states of the world, and also that the UN is able to set the international agenda within selected policy fields. To a large extent, the critical approaches are in agreement with the realists in so far as they share a quite sceptical view of the possibility that the UN can play a strong international role. From this brief presentation of different theoretical approaches to the study of the UN, it is obvious that the basic argument of the chapter is strongly influenced by realist and/or neo-realist thinking.

\section{The decision-making structure of the United Nations}

The UN consists of a number of different bodies and agencies. The most important is the Security Council (UNSC) with 15 members, of which five are permanent. The five permanent members - USA, Russia, UK, China and France - have the right to veto decisions in the Council. The ten nonpermanent members are elected for two-year periods. The main responsibility of the Security Council is to preserve international peace and security. In principle, the Council can make decisions that are binding for all members of the world organization. As a consequence of the responsibility to monitor armed conflicts and other circumstances that may threaten international 
peace and stability, the Council meets regularly throughout the year. It has the authority to implement sanctions against a country that violates the treaty of the UN. Moreover, the Council can require ceasefire between warring parties in an armed conflict. Finally, it can authorize military actions on behalf of the UN. As mentioned above, over the years the Security Council has assumed a central role in relation to the development of the UN's peacekeeping operations.

The General Assembly (UNGA) is another important UN organ. All member states are represented in the Assembly, which meets once a year from September throughout to mid December. On top of the ordinary session, it quite often happens that special sessions are held on specific issues. The General Assembly approves the budget of the organization and it sets the priorities for the year ahead; moreover, it calls international conferences. Unlike the decisions of the Security Council, the decisions of the General Assembly are not binding on the member states. On the other hand, the decisions, declarations and resolutions are important because they are usually considered to express the opinion of the rather diffuse 'world public'. Over the years, a number of specialized agencies have been established under the General Assembly, such as the United Nations High Commission for Refugees (UNHCR, est. 1950), which has the responsibility for taking care of refugees, the United Nations Development Programme (UNDP, est. 1966) with the responsibility to coordinate the efforts of the UN to promote economic and social development, and the United Nations Environment Programme (UNEP, est. 1972) a special agency with the responsibility for environment.

It is also important to mention that the Secretary General is one of the important posts in the UN. The Secretary General heads the Secretariat, which consists of more than 10,000 individuals who are located in the New York headquarters and in the offices in Vienna and Geneva, which is headquarters for the UNHCR. The Secretary General is not only the administrative head of the Secretariat, it is also his responsibility to 'draw to the attention of the Security Council any matter which according to his opinion can threaten the preservation of international peace and security' (UN Treaty, §99). The article clearly implies that the Secretary General can play a political role. However, it is the general view that the Secretary General keeps a low profile and only takes initiatives that could be tolerated by the great powers.

\section{UN peacekeeping in Africa}

In spite of the fact that the UN's primary responsibility is to preserve international peace and stability, it is interesting to note that peacekeeping is not mentioned in the UN Charter. It was 'originally developed during the post-war decolonisation period as a means of filling the power vacuums caused by decolonization. ... It was most controversial when it dealt with 
conflicts within the borders of states (the Congo, Cyprus) and in situations where there was not government authority ...' (Brian Urquhart, UN UnderSecretary General from 1974-86, in Urquhart 1993: 91-2). The first UN peacekeeping operation in sub-Saharan Africa was initiated in June 1960 in the wake of the independence of the former Belgian colony of the Congo. However, by far the greater part of the UN's military involvement in subSaharan Africa has been in the post Cold War period. With the increase in the number of UN military operations in sub-Saharan Africa and the growth in the number of troops deployed in the region, it is striking that 'at all events, peacekeeping remains as amorphous a concept in Africa at the beginning of the twenty first century as it had been in the middle of the twentieth' (MacQueen 2002: 13).

The Congo operation proved to be something of a one-off for the UN. No new peacekeeping commitments were undertaken in Africa until the Cuban military withdrawal from Angola in 1989 and the UN's involvement in the independence process in Namibia (ibid.: 14). A number of circumstances can explain why the UN did not get involved in any kind of military operation in sub-Saharan Africa between June 1964, when the Congo mission formally ended, and 1989. First of all, the Congo operation was generally not considered a positive experience for the UN. Subsequently, different critiques have been propounded, including the claim that, to a considerable extent, the UN peacekeeping force collaborated with US policy-makers and in doing so, advanced the American's strategic objectives (Gibb 2000; MacQueen 2002: 33-57). Second, from the early 1960s and till the mid 1970s, Africa was largely insulated from global ideological competition and thus from the competition for spheres of influence that characterized the Cold War era. Therefore, the region was left on its own or at the discretion of its former colonial masters if violent conflict, war and peace were on the agenda. Third, the region was relatively free from international conflicts, i.e. conflicts between states. However, with the military take-over of power in Addis Ababa in 1974 and with continuing civil war in Angola after 1975, the two superpowers became increasingly involved in the continent, though they engaged themselves via clients and substitutes (Halliday 1989). It was perhaps 'because of rather than despite this new danger (i.e. the superpower involvement) UN interventions were now an even more distant prospect', Norrie MacQueen claims (op. cit.: 16).

\section{Post Cold War interventions}

Almost all post Cold War conflicts in Africa have been conflicts within sovereign states and thus not conflicts of the kind that the UN was originally created to manage: "The more typical "African" problems, which any new multilateralism would have to face, were just those regional, clan, ethnic, and ideological problems thrown up in Somalia and the Great Lakes area and of course in Angola itself, when the endogenous sources of conflict overwhelmed the limited capacity of the (UN)' (MacQueen 1998: 418). This type of 


\section{Gorm Rye Olsen}

internal conflicts have proved to be much harder than inter-state conflicts for the UN and other international actors to prevent, manage and resolve. Many internal conflicts involve highly sensitive issues, such as discrimination between ethnic groups. Very often, one of the parties involved is a guerrilla group, which for obvious reasons has limited experience of international mediation and keeping international agreements. Because of the irregular status of the guerrilla fighters, the governments are often opposed to involving the rebel groups as equal partners in peace negotiations (Goulding 1999: $157 \mathrm{ff})$.

Nevertheless, the 1990s became the most active decade for the UN peacekeeping activities in Africa. This is probably to be explained by the fact that the end of the Cold War generated a sense of optimism and activism at the UN. The success of the multifunctional operation in Namibia in 1989-90 along with the US-led operation against Iraq in 1990-1 created a sense that for the first time since its creation the UN could be used to its full potential. Its activities directed at the promotion of peace and stability in Africa expanded almost exponentially. At the same time, the Security Council moved into new territory with the authorization of the use of force by the UN troops in Somalia, which were operating on a peacekeeping mandate.

In the course of 1992, the UN Security Council passed several resolutions on Somalia. In November 1992, UN Secretary General Boutros BoutrosGhali warned the Security Council that the situation in Somalia has been aggravated beyond the point where peacekeeping operations alone were needed. The Council had no 'alternative but to mount more powerful measures in order to secure the humanitarian operations in Somalia'. Against that background the UN Secretary General stated that 'for the time being no government exists in Somalia which can ask for the deployment of such a force' to protect the humanitarian operations in the country. The US offered troops for a massive military operation in Somalia in the name of the UN, in order to make sure that international emergency assistance could be delivered to the people in need in spite of civil war and anarchy (Woodward 1998: $146 \mathrm{ff}$ ). Though the Secretary General and a number of member states preferred a UN-controlled operation, the Council ended up unanimously voting in favour of a humanitarian operation. UN Security Council Resolution 794 of 3 December 1992 authorized 'the use of all necessary means in order to as fast as possible to establish as soon as possible a secure environment for the humanitarian relief operations in Somalia' (UN 1992). It is worth noting that it was the fate of the Somali people that was used as the ultimate reason for the endorsement of the intervention.

Within a few weeks of the landing of the American troops at the beaches outside Mogadishu in December 1992, almost 38,000 troops, of which three quarters came from the US, were deployed in Somalia. In spite of the quite impressive number of foreign troops, the clan wars and the general anarchy soon resumed. The ambush of a group of Pakistani UN peacekeepers in June 1993 and later the killing of 18 Americans (Woodward 1998: $150 \mathrm{f}$; MacQueen 
2002: $212 \mathrm{ff}$ ), led the UN military leadership in Somalia (which happened to be under a US admiral) to conclude that use of maximum military force was necessary in order to 'neutralize' one particular clan leader. This remarkable change in strategy meant that the UN objectives changed from peacekeeping to peacemaking (Woodward 1998: $150 \mathrm{ff}$ ).

The shift in military strategy did not bring an end to the civil wars in the country. Nevertheless, during 1994 the UN troops, including American marines and other foreign soldiers, left Somalia in a state of anarchy just as bad as it was when the Americans landed two years before. In the mass media, the withdrawal from Somalia was described as a massive defeat for the UN and for its efforts to maintain peace in the new post Cold War era (Woodward 1998: 150 ff; MacQueen 2002: 217 ff). For the US, the failure in Somalia meant that the Washington became much more reluctant to deploy troops in peacekeeping operations directed by the UN. Thus, President Bill Clinton stressed in his speech to the UN General Assembly in September 1993: 'The United Nations simply cannot engage in every conflict around the world. If the American people are going to say yes to participate in UN peacekeeping, the UN must learn to say no' (White House 1993).

The result of the operation in Somalia was a general retrenchment and re-thinking of the UN's peacekeeping activities both in Africa and in the world at large. The genocide in Rwanda in 1994 clearly brought an end to the first years of post Cold War activism and optimism on behalf of the UN. As a consequence of the killings of a number of Belgian peacekeepers, and just as genocide was about to begin in early April 1994, the UN pulled out its limited troops from the small Central African country of Rwanda. Four weeks before the massacres began there was evidence of targeted killings of ethnic minorities, an increase in weapons imports and radio broadcasts of hate-filled speeches (MacQueen 2002: $71 \mathrm{ff}$; Green and Luehrmann 2003). By the time the genocide was over, more than 800,000 people had been slaughtered. Within the UN, the US and other countries blocked military action to prevent the genocide (Shawcross 2000: $117 \mathrm{ff}$; Report 1999: $15 \mathrm{ff}$ ). Moreover, the US made strong efforts to play down the magnitude of the atrocities by instructing its representatives to refer to the situation in Rwanda as 'acts that may lead to genocide', instead of speaking about a planned and systematically implemented policy being carried out (MacQueen 2002: 75). The background to these American linguistic dodges was an apprehension that Washington would have to mount a big operation if the situation in Rwanda fell under the UN's Convention on Genocide (Shawcross 2000: $118 \mathrm{f}$; Sellström and Wohlgemuth 1996: 54).

After days of very difficult negotiations, the Security Council agreed on a resolution to deploy 5,500 troops to protect as many people as possible and at the same time make sure that the emergency assistance was delivered. A number of African countries indicated that they were ready to provide the necessary troops for a UN force in Rwanda. However, the African soldiers were short of both equipment and means of transportation needed to carry 


\section{Gorm Rye Olsen}

out an operation. Both the American and the British authorities, however, more or less openly blocked the practical possibilities, including providing air lift capacity and vehicles for the African peacekeepers (MacQueen 2002: 76f, $84 \mathrm{f}$; Shawcross 2000: $118 \mathrm{f}$ ).

Depending on the approach to the Rwandan tragedy, at least two interpretations are possible. A realist-inspired interpretation would stress that because of limited interests in Rwanda, the US and other big powers blocked any real actions being taken to stop the genocide. Or as Andrew Sullivan commented: 'The massacres were so great, the situation so complex, and western interests so minimal that intervention is clearly unrealistic and unwise' (Sunday Times, 24 April 1994, quoted by Furley 1998: 248). A less state-centric approach would stress the failure of the UN as an independent organization, that it was unable to prevent the tragedy. Irrespective of the interpretation, it soon became obvious that for the UN, Rwanda meant that the world organization, and in particular the US and other permanent members of the Security Council, became even less inclined to intervene in the violent conflicts in Africa.

Nevertheless, a number of minor missions was carried out in the years following 1994. Probably the most significant was the UN Angola Verification Mission III, lasting from February 1995 until 1 June 1997 and involving more than 8,000 troops. The aim of the mission in Angola was to contribute to national reconciliation by overlooking the ceasefire, to separate the different armies, and to control the demobilization of the armed forces and the establishment of a common Angolan army. In addition, it would seek to distribute emergency relief and contribute to mine-clearing (MacQueen 1998).

The biggest and therefore the most remarkable UN peacekeeping operation in Africa after Somalia was set up in 1999, when the Security Council agreed to deploy a force of 13,000 troops in Sierra Leone. The main aim of the UN force was to monitor the implementation of the peace agreement between the government of Sierra Leone and the RUF guerrillas. Moreover, a number of additional purposes were also included in the mandate. The Secretary General

Kofi Annan described the operation in Sierra Leone as a 'robust peacekeeping force' that was to behave impartially like a traditional peacekeeping force but at the same time was allowed to use its military capacity to deter attacks and thus defend the mandate, if necessary (MacQueen 2002: 188-91).

However, the actual course of events on the ground in Sierra Leone showed that the UN force faced tremendous problems in meeting the demands this type of peace-enforcing operation entails. Not only was it very difficult to find a sufficient number of soldiers but also the UN was primarily only able to recruit troops from the developing countries, which in most cases were not adequately trained for the job in Sierra Leone and moreover their equipment was often outdated. On top of these very practical problems, the operation was characterized by internal disagreements and problems with co-operation, including widespread allegations of corruption. The numerous weaknesses of 
the UN operation were exposed when, in May 2000, the RUF captured loads of materiel from the UN troops and moreover took almost $400 \mathrm{UN}$ soldiers as hostages. The total breakdown of the whole operation was prevented only by the deployment of 800 paratroopers from Britain that helped stabilize the situation in the country (MacQueen 2002: 191-5).

\section{New trends in UN peacekeeping?}

After two years of war between Eritrea and Ethiopia costing thousands of lives, a ceasefire was finally reached in June 2000. In September that year, a traditional - i.e. Chapter VI - UN peacekeeping operation of up to 4,300 military personnel began with the deployment of troops from a number of Western countries (such as Canada, the Netherlands and Denmark) began on the Eritrean side of the ceasefire line. The main purpose of this operation was to monitor a ceasefire between the regular armies of the two neighbouring countries, including the withdrawal of troops from the combat zone. Compared to the other post Cold War UN operations in Africa, this was considered as a straightforward mission without the dangers and pitfalls that characterized other African operations. First of all, the war was fought between two relatively disciplined armies and involved no war lords or irregular guerrilla groups. Second, before most of the troops were deployed a formal peace agreement was signed between the two countries. Finally, the issue that was fought over was considered fairly 'simple' to solve because it 'only' involved disagreement on where to draw the borderline between the two countries (MacQueen 2002: 221). Because of these unique circumstances, there was a remarkable Western willingness to provide troops. Therefore, the UN mission to the Horn of Africa cannot be generalized to cover other African conflict situations, and so has to be considered as an exception (MacQueen 2002: 229-31).

If the Eritrean-Ethiopian border mission was an exception from the general pattern of UN involvement in peacekeeping operations in Africa, the same cannot be said about the first big operation in the new millennium. In August 2003, the Security Council unanimously adopted a resolution under Chapter VII of the UN Charter stating that the situation in Liberia constituted a threat to international peace and security in the region, and establishing a UN stabilization force of up to 15,000 military personnel. This force would monitor disarmament, demobilization and reintegration of combatants and, in due course, it would contribute to the holding of elections. The Liberia operation had a number of similarities with all other UN missions carried out in Africa in the post Cold War period, with the exception of Eritrea-Ethiopia. Thus, for example, the UN troops were deployed in a situation that followed years of instability and casual violence causing massive sufferings among civilians (Berman and Sams 2000: $88 \mathrm{ff}$; Cleaver 1998: $223 \mathrm{ff}$; MacQueen 2002: $169 \mathrm{ff})$. In the summer of 2003, fighting intensified between government forces and various warring factions. As the 


\section{Gorm Rye Olsen}

fighting moved into the capital Monrovia, a humanitarian tragedy became imminent. On 1 August, the Security Council adopted a resolution that authorized the establishment of a multinational force in Liberia and declared its readiness to establish a follow-on UN stabilization force to be deployed no later than October 2003. Based on the clear reluctance among the big powers in the Security Council to deploy UN peacekeeping troops in Africa, the operation did not involve the deployment of Western troops but overwhelmingly consisted of non-Western soldiers with a Kenyan general as commander (www.un.org).

In summary, willingness to engage the UN in peacekeeping and peacemaking operations in Africa changed quite dramatically during the 1990s after almost 30 years of inactivity. International optimism and the basically undefined international power structure following the end of the Cold War explain to a large extent the big powers' agreement to become involved on the continent via the UN. With the failure of the Somalia operation, however, attitudes returned to the traditional scepticism and reservations of the days of the Cold War about the capacity of the UN. This manifested itself clearly in the reluctance to let the UN, let alone one of the big powers, get involved in Africa. This was strikingly clear in Rwanda and in other cases. When the Western opposition to greater UN involvement weakened, it was either in a case where there was little chance of casualties and of failure, such as the mission on the Ethiopian-Eritrean border, or concerned situations where no Western troops were involved.

At the same time as the UN struggled with operational problems, the organization had continually to contend in the years following the end of the Cold War with far too few resources (Eriksson et al. 1995: 62). By 31 October 2000 , outstanding contributions amounted to more than $\$ 2$ bn. However, by 31 December 2001, unpaid contributions to peace-keeping accounts were $\$ 1.9$ bn and as of 30 September 2003, they were down to $\$ 1.56$ bn (www.un. org/Depts/dpko/dpko/publ/pko.htm).

\section{The UN's development efforts in Africa}

Due to the decolonization process, Africa became an important geographical region for the development efforts of the UN. It was no coincidence that the UN decided that the 1960s were to be 'a decade of development', planning for the GNP of the developing countries to grow at an annual rate of five per cent throughout the decade (Iriye 2002: $103 \mathrm{ff}$ ). The 1960s and the following decade, the General Assembly and its sub-organizations became the arenas where Third World countries, which now made up more than half the membership, expressed their collective interests and concerns. In the 1970s, the developing countries began to lobby for what they called a 'new international economic order', in which their special circumstances would be given stronger consideration and their products receive preferential treatment (ibid.: 141; Murphy 1997: 206-12). The 1970s and the 1980s were very difficult 
decades because of the high political profile of a large number of developing countries that voted in favour of resolutions in the General Assembly on apartheid South Africa, continued white-settler regimes in Namibia and Southern Rhodesia, racism and 'Zionism', and the far-reaching demands for a 'new international economic order'. A. J. R. Groom points out that Resolutions like these brought about the blind, negative responses from the likes of Ronald Reagan and Margaret Thatcher (Groom 2003: 128).

The development policy of the $\mathrm{UN}$ is implemented by a number of specialized sub-organizations with their own administrative systems and their own governing boards, including a separate political leadership. Because of the radicalization of the Afro-Asian majority in the General Assembly in the 1970s, the US began to use the financial weapon, reducing its financial contributions to the different UN development programs aimed at promoting economic and social development (Armstrong et al. 1996: $100 \mathrm{ff}$; Taylor 1993: $142 \mathrm{ff}$ ). Moreover, the US and a few other developed countries were dissatisfied with a situation in which they contributed the bulk of the financial resources but could be outvoted by a coalition of states that each contributed less than 0.1 per cent of the budget of the world organization (Taylor 1993: 142). However, the US was not alone in its scepticism towards the UN and its capacity in different policy fields. A number of rich countries headed by the US also raised strong criticism of the efficiency of the UN and particularly its budgetary processes.

Table 1 clearly shows that, compared to the situation in the mid 1980s when more or less equal amounts of development assistance were channelled to sub-Saharan Africa via the World Bank/IDA and the UN system by the beginning of the new millennium, the situation was very different. During the 15 years covered in Table 1, total disbursements of development aid to Africa was reduced by about 15 per cent, from $\$ 16,473 \mathrm{~m}$ in $1985-6$ to $\$ 13,855 \mathrm{~m}$ in 2001. In the same period the aid disbursed by the UN organizations was reduced by no less than 50 per cent, i.e. significantly more than the average for the other donors. By comparison, the aid disbursed by the World Bank/IDA increased by some 33 per cent from the mid 1980s until 2001, resulting in a situation where the disbursements by the World Bank were three times the total amount of aid disbursed by the different UN organizations. The result of the radically changed relationship between the World Bank and the UN system is quite clearly that 'the World Bank is (now) the world's largest lending body and the largest source of development aid and ... (it has) the largest impact on economic policies and development' in many poor countries, not least in Africa (Dutt 2003: 120).

The reductions in the financial contributions to the UN organizations meant that, in 2001, aid to sub-Saharan Africa disbursed by the UN system was less than the amount of aid disbursed by a many bilateral donors, for example France and Japan. These simple figures are the basis for the conclusion of James Muldoon in a recent book, where he states that international organizations are not the primary agents of development assistance; 


\section{Gorm Rye Olsen}

Table 1 Net ODA disbursements to sub-Saharan Africa by donor, 1985-2001 (\$m at 2000 prices and exchange rates)

\begin{tabular}{lrrrrr}
\hline & $1985-6$ & $1990-1$ & 1997 & 1999 & \multicolumn{1}{c}{2001} \\
\hline UNDP & 389 & 347 & 281 & 202 & 132 \\
UNICEF & 175 & 227 & 157 & 147 & 189 \\
UNHCR & 325 & 256 & 144 & 142 & 237 \\
WFP & 490 & 631 & 84 & 170 & - \\
Other UN organizations & 171 & 160 & 74 & 61 & 177 \\
Total UN & $\mathbf{1 , 5 5 0}$ & $\mathbf{1 , 6 2 1}$ & $\mathbf{7 4 0}$ & $\mathbf{7 2 2}$ & $\mathbf{7 3 5}$ \\
World Bank/IDA & 1,803 & 2,019 & 2,146 & 1,659 & 2,419 \\
Total multilateral & $\mathbf{5 , 2 1 9}$ & $\mathbf{6 , 3 8 5}$ & $\mathbf{5 , 0 9 2}$ & $\mathbf{4 , 3 3 3}$ & $\mathbf{5 , 4 5 9}$ \\
France & 1,944 & 2,723 & 1,814 & 1,230 & 957 \\
Germany & 1,087 & 1,274 & 763 & 782 & 652 \\
Norway & 347 & 378 & 384 & 332 & 278 \\
Japan & 705 & 1,154 & 860 & 1,027 & 972 \\
Total bilateral & $\mathbf{9 , 7 3 3}$ & $\mathbf{1 0 , 8 2 6}$ & $\mathbf{7 , 8 3 0}$ & $\mathbf{7 , 4 2 7}$ & $\mathbf{8 , 2 6 4}$ \\
Total bi- and multilateral & $\mathbf{1 6 , 4 7 3}$ & $\mathbf{1 7 , 7 5 1}$ & $\mathbf{1 3 , 0 3 2}$ & $\mathbf{1 1 , 8 8 0}$ & $\mathbf{1 3 , 8 5 5}$ \\
\hline
\end{tabular}

Source: OECD 2003, The DAC Journal. Development Cooperation, 2002 Report, Paris: OECD, p. 286.

multilateral aid represents only a small proportion of total Official Development Assistance that flows to the developing countries. . . International organizations have done more in shaping the ideas of and influencing donor policies for international development' (Muldoon 2004: 233-4).

It may not be sufficient to base the conclusion of the steadily shrinking significance of the UN in Africa on the absolute figures for aid volumes only. It may also be relevant to look at the specific activities performed by different UN sub-organizations. Over the years, the UNHCR has been one of the most important sub-organizations of the UN operating in Africa. For that reason, it will be dealt with at some length in the next section. In the mid 1980s UNDP was another important sub-organization, though it is obvious from Table 1 that its funds have been reduced by no less than two thirds over the past 20 years. Traditionally, the UNDP has provided advisory and support services to African governments. The assistance has mostly been non-monetary, comprising the provision of experts' services, consultancies and training of local work forces.

In the wake of the ending of the Cold War and due to considerable pressure and criticism from a number of donor governments, the UNDP increasingly moved into new policy fields, such as human development, capacity-building, and promotion of good governance, including democracy. Also the organization got involved in crisis prevention and recovery, energy and environmental activities and in combating aids, etc. (Klingebiel 1998). It is worth noting that the UNDP's emphasis on the promotion of good 
governance and democracy was in no way unique to the aid community in the 1990s. All donors, at least in declarations, gave high priority to promoting democracy and human rights (Crawford 2001). However, whereas, for example, the US channelled considerable amounts of money, relatively speaking, into this particular policy area (OECD 2003: 269f), the funds for the UNDP were reduced quite significantly as shown in Table 1 . This makes it difficult not to conclude that when there is a high-profile issue such as promotion of democracy, the big powers prefer to use their own bilateral development organizations and not the UN to pursue such a policy. In consequence of such choices, the UNDP automatically turned into a minor player in this field.

In summary, in the early years of postcolonial rule and into the 1970s, the UN was considered an important development organization in Africa. From the mid 1970s and during the remaining years of the Cold War, its significance dwindled slowly but steadily. In the years following the end of the Cold War, its limited position in Africa became even more obvious. Therefore, the changes that took place during the 1990s underline two important things. First, the dominant powers, which are more or less equivalent to the big donors, maintained their political scepticism of the 1970s towards the UN with respect to its capacity and efficiency to promote development in Africa. Instead of the UN, the big powers relied on the World Bank and on their own bilateral aid to pursue this goal. Second, the scepticism towards the UN was so strong that the reductions in grants to the UN organizations were disproportionately larger than the average cuts in the bilateral aid disbursements. In the midst of these general reductions in aid transfers, the disbursements of the World Bank increased significantly.

\section{Emergencies and refugees}

The UN's humanitarian system comprises a number of key actors such as UNHCR, WFP, UNICEF, OCHA, and others that are involved in humanitarian operations and emergencies. In the net disbursements of assistance to sub-Saharan Africa shown in Table 1, the UNHCR is the most prominent of these organizations. Therefore, this section focuses specifically on this particular UN organization.

Table 2 shows that the number of refugees and internally displaced persons (IDPs) in Africa has remained high for a number of years. Taking refugees and internally displaced persons together, during the latter half of the 1990s close to six million Africans were the concern of the UNHCR (UNHCR 2002a), equivalent to one-third of the total population of refugees and IDPs throughout the world. Both natural disasters and mainly man-made emergencies forced a large number of human beings to flee their home region (UNHCR 2002a). Out of the 20 top 'refugee-producing' countries around the world, about half are African. Moreover, Africa provides ten of the 20 countries with the largest IDP populations (Crisp 2000: 2). In relation to the 


\section{Gorm Rye Olsen}

Table 2 The number of refugees and internally displaced person in sub-Saharan Africa, 1997-2001

\begin{tabular}{lllllr}
\hline Region & 1997 & 1998 & \multicolumn{1}{l}{1999} & \multicolumn{1}{l}{2000} & \multicolumn{1}{c}{2001} \\
\hline West and Central Africa & $1,931,800$ & $2,449,700$ & $1,956,000$ & $1,569,700$ & 888.9 \\
Great Lakes, East and & $3,446,500$ & $3,001,600$ & $2,984,700$ & $3,654,500$ & $2,424,500$ \\
$\quad$ Horn of Africa & & & & & \\
Southern Africa & 264,400 & 241,800 & 290,500 & 603,800 & 602,300 \\
Total & $\mathbf{5 , 6 4 2 , 7 0 0}$ & $\mathbf{5 , 6 9 3 , 1 0 0}$ & $\mathbf{5 , 2 3 1 , 2 0 0}$ & $\mathbf{5 , 8 2 7 , 9 0 0}$ & $\mathbf{3 , 9 1 5 , 7 0 0}$ \\
\hline
\end{tabular}

Source: UNHCR 2002a.

total number of people living in Africa and in relation to local capacity in Africa, the six million refugees and IDPs represent a tremendous burden, which has lead observers to refer to Africa as a 'continent of refugees' (Martin 1999: 830).

The UNHCR operates on its own mandate and on the 1951 Refugee Convention. The primary aim of the organization is to take care of refugees and increasingly, it also has been given the responsibility for IDPs. Because of the magnitude of the problem and because of the fact that the 1990s were declared the 'international decade for curtailment of natural disasters', the UN General Assembly back in 1991 agreed upon a resolution on 'Strengthening the co-ordination of humanitarian emergency aid' aimed at maintaining the UN's central position within this field. The resolution also stipulated a new set of guidelines for the humanitarian work of the UN. The UNHCR works closely with other UN agencies, intergovernmental organizations and NGOs to increase the scope and effectiveness in the delivery of emergency humanitarian relief.

In Africa, the UNHCR has traditionally provided assistance to refugees and IDPs in many parts of the continent, where civil conflict, violations of human rights, drought, famine, and environmental degradation have forced people to flee their home region. The UNHCR was involved in feeding and giving shelter to these people, and the UN was responsible for protecting these large numbers of refugees. On top of this, the UNHCR was involved in assisting the return of large numbers of refugees in several big operations involving several countries (UNHCR 2002b: Fact Sheet June 2000).

The UNHCR was heavily involved in one of the biggest refugee operations ever in Africa, namely that in Zaire/DRC in the wake of the genocide in Rwanda in 1994. When the crisis culminated, it involved at least one million people of whom at least 200,000 lost their lives, mainly because of lack of protection (Emizet 2000). Subsequently, the UNHCR and the UN in general was criticized strongly over their handling of this particular crisis. The criticism was directed towards the obviously insufficient protection of vulnerable individuals living in the big camps inside Zaire/DRC but close to the border with Rwanda. However, there was also criticism that the UN did 
not do anything to remove or eliminate the armed gangs controlling the camps and carrying out massacres for almost ten months (Emizet 2000: 183). The lack of intervention from either the UN or the big powers leads Kisangani Emizet to claim that 'the UN Security Council and especially the US and the UK dropped the plan and decided not to send combat troops' that could have put an end to the massacres (Emizet 2000: 183).

In spite of the obvious need for assistance to support the millions of displaced persons and refugees in Africa, for a number of years the UNHCR has failed to receive adequate international financial support to implement effective relief programmes (Väyryrien 2001: 163f). A closer look at the general funding situation of the UNHCR since 1990 reveals some interesting trends. Every emergency, such as the crisis in the Great Lakes region, requires the creation of special programmes and leads to a major rise in the financial needs of the UNHCR, typically lasting for one or more years. The funding pattern of the 1990s shows that the financial support of the core activities of the UNHCR has remained fairly stable over the years. But the level of annual contributions to the organization partly undermines this positive picture, because these have provided much less than the required amount needed to implement vital special programmes that address acute crises and which often require large sums of assistance (Väyryrien 2001: $149 \mathrm{ff}$ ). Because of constant budget constraints, the organization has repeatedly been forced to revise its programmes downward (UNHCR 2002a: 21). At the beginning of the new century, the UNHCR stated that 'reductions in an already highly prioritised budget affect everyone involved, but most of all the intended beneficiaries' (ibid.: 22).

In summary, there is no doubt that UNHCR and a number of other UN organizations have faced enormous challenges in the numerous emergencies in Africa. The majority of the organization's expenditures has been funded by annual voluntary contributions, mainly from governments. Because of this special financial mechanism, it is relatively easy to read the donor community's willingness to contribute to the activities of UNHCR. Moreover, the UNHCR's dependence on voluntary funding has made the organization vulnerable to donor governments' political priorities for special emergency situations or for special programmes (Väyryrien 2001: 164). Table 1 indicates that the willingness to finance this particular UN organization did not increase during the 1990s. Because the need for financing is so clearly ad hoc based, the figures in Table 1 are not a total reliable indicator of the wider world's willingness to finance humanitarian emergencies in Africa. Therefore, it is necessary to compare the disbursements of UNHCR with the disbursements of other actors in this field.

As a start, there is no doubt that the relative share of global humanitarian assistance given in the form of multilateral contributions to UN agencies has been reduced quite significantly since the 1980s. Thus in 1988, 45 per cent of humanitarian assistance was disbursed through UN agencies. Between 1989 and 1994, their share was reduced to 31 per cent, and towards the end of 


\section{Gorm Rye Olsen}

the 1990s and the first years of the new century, the share was down to around 25 per cent (Randel and German 2002: 21). This trend means that an increasing share of global humanitarian aid is channelled to the recipient areas in the form of bilateral assistance. This development once again reflects a lack of donor trust in the UN system, including the UNHCR. It also indicates that the major donors want to control the purposes and the specific emergencies for which the money is spent. It is much easier to control where the money is spent when the aid is administered by the donor's own national aid organization. Moreover, the interest in controlling where the emergency aid goes and for what purposes is reflected in the strong trend towards earmarking the money, which enhances government control. Based on these figures given above, it is difficult to escape the conclusion that even within this narrow and morally influenced policy area of humanitarian emergencies, the United Nations was not able to maintain a strong position in Africa. Quite simply, the big powers and the big donors gave priority to their own national aid and emergency organizations.

\section{Concluding remarks}

Africa is a peripheral region in the global system. Applying a realist or neo-realist understanding of international relations, it is obvious that the "big players' of the world will not give high priority to Africa in their overall foreign policy priorities. On the other hand, the possibility cannot be ruled out that an intergovernmental organization like the UN could or would compensate for the lack of interest in Africa among the leading powers in the world. The analysis here has clearly shown that this has not been the case. It has been the general argument of this chapter that the UN to a very large extent has been an instrument of the leading powers, and here an instrument of the US in particular. Because these powers and the US in particular have given low priority to Africa and because they have become increasingly sceptical of the capacity and effectiveness of the world organization, their funding of the UN system has been steadily reduced since the 1970s.

The strongly pressured budgets have forced the UN to reduce its activities in the field of development quite dramatically. In the areas of operation of the UNHCR, it has had to cut down on its activities, too. During the 1990s, development assistance has in general been reduced, with one remarkable exception: the aid disbursed by the World Bank, which has increased. The latter fact indicates that the leading powers can control the Bank whereas the UN system is difficult to control. Moreover, the UN is also in general considered inefficient. Within the area of humanitarian assistance, the reduction in disbursements by UNHCR have to some extent been compensated by the increase in the disbursements by bilateral aid organizations and by the EU's humanitarian organization, ECHO. Again, this pattern reflects reservations among the leading powers about the UN and a correspondingly higher degree of trust in the bilateral aid systems. 
Finally, the analysis of a selected number of peacekeeping operations carried out by the UN in Africa during the 1990s confirms the picture just described. However, the confirmation comes about in a more indirect way and is to a certain extent blurred by the striking level of activity of the UN in the field of peacekeeping. All operations except the one on the EritreanEthiopian border have been carried out in highly complex and very difficult situations characterized by internal conflict and civil war. It is indicative that the leading Western powers have been very reluctant to let their own soldiers participate in peacekeeping operations under such circumstances since the failure in Somalia. On the other hand, they accepted that non-Western troops should participate in this type of operation, even though the US for a number of political reasons has withheld its contributions to the UN's peacekeeping operations. Washington has thereby caused serious problems for the funding of the missions agreed upon in the Security Council.

The striking pattern of acceptance of peacekeeping operations in Africa but without the participation of Western troops confirms the conclusion that the leading Western powers do not regard Africa as a high priority and therefore are reluctant to deploy their own soldiers in difficult and dangerous situations in Africa. That the very same powers in the Security Council have voted in favour of letting the UN be responsible for peacekeeping missions can be interpreted as an expression of cynicism or as lack of interest. Of course, it can also be seen as a reflection of their need for symbolic policy, i.e. to appear to act while letting somebody else do the dirty work.

\section{References}

Archer, C. (2003) International Organizations, third edition, London: Routledge.

Armstrong, D., Lloyd, L. and Redmond, J. (1996) From Versailles to Maastricht. International Organisation in the Twentieth Century, London: Palgrave.

Berman, E. G. and Sams, K. E. (2000) Peacekeeping in Africa: Capabilities and Culpabilities, Geneva: UNIDIR.

Bøås, M. and McNeill, D. (2003) Multilateral Institutions. A Critical Introduction, London: Pluto Press.

Cleaver, G. (1998) 'Liberia: Lessons for the Future from the Experience of ECOMOG', in O. Furley and R. May (eds), Peacekeeping in Africa, Aldershot: Ashgate, pp. 223-38.

Crawford, G. (2001) Foreign Aid and Political Reform. A Comparative Analysis of Democracy Assistance and Political Conditionality, Houndmills: Palgrave.

Crisp, J. (2000) Africa's Refugees: Patterns, Problems and Policy Challenges, New Issues in Refugee Research, Working Paper No. 28, Geneva: Evaluation and Policy Analysis Unit, UNHCR.

Dutt, A. K. (2003) 'Globalization, North-South Uneven Development and International Institutions', in John-ren Chen (ed.), The Role of International Institutions in Globalisation. The Challenges of Reform, Cheltenham: Edward Elgar, pp. 101-33.

Emizet, K. (2000) 'The Massacre of Refugees on Congo: A Case of UN Peacekeeping Failure and International Law', The Journal of Modern African Studies, Vol. 38, No. 2, pp. 163-202. 


\section{Gorm Rye Olsen}

Eriksson, L. et al. (1995) FN. Globalt uppdrag. Fakta. Historia. Framtid, Jyväskylä: Gummerus Printing.

Furley. O. (1998) 'Rwanda and Burundi: Peacekeeping Amidst Massacres', in O. Furley and R. May (eds), Peacekeeping in Africa, Aldershot: Ashgate.

Gibb, D. N. (2000) 'The United Nations, International Peacekeeping and the Questions of "Impartiality": Revisiting the Congo Operation of 1960', Journal of Modern African Affairs Vol. 38, No. 3, pp. 359-82.

Goulding, M. (1999) 'The United Nations and Conflict in Africa since the Cold War', African Affairs, Vol. 98, pp. 155-66.

Green, D. and Luehrmann, L. (2003) Comparative Politics of the Third World. Linking Concepts and Cases, Boulder, CO: Lynne Rienner.

Groom, A. J. R. (2003) 'The United States and the United Nations: Some Revolting European Thoughts', Journal of International Relations and Development, Vol. 6, No. 2, pp. 120-38.

Halliday, F. (1989) Cold War, Third World. An Essay on Soviet-US Relations, London: Hutchinson Radius.

Hasenclever, A., Mayer, P. and Rittberger, V. (1997) Theories of International Regimes, Cambridge: Cambridge University Press.

Iriye, A. (2002) Global Community. The Role of International Organizations in the Making of the Contemporary World, Berkeley, CA: University of California Press.

Klingebiel, S. (1998) 'Reform of the United Nations Development Program (UNDP)', The International Journal of Technical Cooperation, Vol. 4, No. 2, pp. 200-12.

Krasner, S. (1983) 'Structural Causes and Regime Consequences: Regimes as Intervening Variables', in S. Krasner (ed.) International Regimes, Ithaca, NY: Cornell University Press, pp. 1-21.

MacQueen, N. (1998) 'Peacekeeping by Attrition: The United Nations in Angola', The Journal of Modern African Studies, Vol. 36, No. 3, pp. 399-422.

-(2002) United Nations Peacekeeping in Africa Since 1960, London: Longman.

Martin, M. T. (1999) "Fortress Europe" and Third World Immigration in the PostCold War Global Context', Third World Quarterly, Vol. 20, No. 4, pp. 821-38.

Muldoon, J. P. (2004) The Architecture of Global Governance. An Introduction to the Study of International Organizations, Boulder, CO: Westview Press.

Murphy, C. N. (1997) 'What the Third World Wants: An Interpretation of the Development and Meaning of the New International Economic Order Ideology', in P. F. Diehl (ed.), The Politics of Global Governance. International Organizations in an Interdependent World, Boulder, CO: Lynne Rienner, pp. 201-15.

OECD (2003) The DAC Journal. Development Co-operation. 2002 Report, Paris: OECD.

Pease, K.-K. (2003) International Organizations, Upper Saddle River, NJ: Prentice-Hall.

Report (1999) Report of the Independent Inquiry into the Actions of the United Nations during the 1994 Genocide in Rwanda. Online: <www.un.org/News/ossg/ rwanda_report.htm>.

Randel, J. and German, T. (2002) 'Trends in the Financing of Humanitarian Assistance' in J. Macrae, (ed.), The New Humanitarianisms: A Review of Trends in Global Humanitarian Action, HPG Report, London: ODI, pp. 19-28.

Sellström, T. and Wohlgemuth, L. (1996) The International Response to Conflict and Genocide: Lessons from the Rwanda Experience. Study 1. Historical Perspective: Some Explanatory Factors, Odense: Steering Committee of the Joint Evaluation of Emergency Assistance to Rwanda. 
Shawcross, W. (2000) Deliver US from Evil. Warlords and Peacekeepers in a World of Endless Conflict, London: Bloomsbury.

Taylor, P. (1993) International Organization in the Modern World. The Regional and the Global Process, London: Pinter.

UN (1992) United Nations Security Council Resolution 794, SC Res. 794, 47 UN SCOR at 63, UN DOC. S/RES/794.

UNHCR (2002a) UNHCR. Global Report 2002, Geneva: UNHCR.

_ Fact Sheet (2002b) United Nations High Commissioner for Refugees, Geneva: UNHCR Public Information Section, June 2002.

Urquhart, B. (1993) 'The UN and International Security after the Cold War', in A. Roberts and B. Kingsbury (eds), United Nations, Divided World. The UN's Roles in International Relations, Oxford: Clarendon Press, pp. 81-103.

Väyryrien, R. (2001) 'Funding Dilemmas in Refugee Assistance: Political Interests and Institutional Reforms in UNHCR', International Migration Review, Vol. 35, No. 1, pp. 143-67.

White House (1993) Office of the Press Secretary, New York, 27 September.

Woodward, P. (1998) 'Somalia', in O. Furley and R. May (eds), Peacekeeping in Africa, Aldershot: Ashgate, pp. 143-58.

World Bank (2000) Can Africa Claim the 21st Century?, Washington, DC: The World Bank. 


\section{Africa and the North Policy communities and
different types of state -
theoretical challenges}

Ulf Engel and Gorm Rye Olsen

The individual chapters in this book have addressed a number of key questions and key issues that are inspired by the debates in current international relations theory. The first question is whether Africa figures on the foreign policy agenda of some of the most important international actors. Moreover, is it possible to identify significant changes in their policies towards Africa over the last 40 to 50 years? Basically, do the individual OECD member states have a (national) interest in the fate of Africa, or have global developments as well as developments in Africa itself over the last couple of decades made the region irrelevant to many big external actors?

Based on the analyses in this book, it is possible to answer cautiously 'yes' to the question whether the big actors have an interest in Africa. In the post-colonial era, this interest was generally quite limited. In most OECD countries, it is even possible to maintain that the interest in Africa was waning. However, the preceding analyses also show that the interest in Africa changed with the terrorist attacks on September 11, 2001. The interest in political stability in Africa, which has been underlying the policy of most OECD member states, became much more obvious. In the case of the US not least, stability and conflict management no doubt became the most important goal of its Africa policy.

Among the actors analysed here, there is no doubt that Africa in general has been and continues to be most important to France. Jean-François Médard argued that Africa has been and still is important because of France's special 'civilizing mission', which the French elite seems to be in agreement about. On the other hand, it has to be acknowledged that the significance of Africa has decreased slowly but steadily since the ending of colonialism. In spite of this development, Africa still has a high priority in French foreign policy as far as conflict management and maintaining stability (read: status quo) is concerned. Because of the already fairly high priority given to this particular issue, the terrorist attacks on New York and Washington DC on September 11, 2001 did not change French Africa policy in any fundamental ways.

By contrast, Africa figures much less prominently on the foreign policy agenda of the other former major big European colonial power, the UK. 
Africa and the North 163

Since formal independence was granted to her colonies in Africa, the UK has been very anxious to avoid criticism of neo-colonialism, a position very different from the French. In general, British policy towards Africa has been much more low-profile between the end of the colonial era and September 11, 2001. Following the attacks on the US, there is no doubt that Africa has become of considerable importance to British foreign and security policy, among other things in connection with the explicit argument for the need to forestall a new Afghanistan, as Gordon Cumming pointed out. He also suggested that Britain has adopted a more interventionist policy towards Africa in recent years, not least following September 11.

Turning to the US, Donald Rothchild and Nikolas Emmanuel began their analysis of the US Africa policy by stating that the region is of limited interest to the only remaining superpower. On the other hand, over the years there has been a constant interest in maintaining and promoting 'stability' on the continent. For obvious reasons, this particular interest has only been strengthened because of September 11 and, in the wake of those events, the US administration has become much more explicit in its judgement that the 'weak' and 'failed' states in Africa represent a potential security risk. The reason for this is that these states are simply seen as not capable of policing their own territory and their borders, thus opening up the possibility that terrorist groups can establish camps and facilities on their territory. The 'failed states' also represent a security threat to the outside world because, for different reasons, they may accept terrorist cells on their territory.

By contrast, Africa has only instrumental interest to Japan, Bolade Eyinla pointed out. Africa is important to Japanese foreign policy for narrow economic reasons, such as export markets and as a source of raw materials. In recent years, it has also become increasingly important to Japan's foreign policy strategy because support from African governments is considered a crucial precondition for winning international support for Japan's ambition to have a permanent seat on the UN Security Council. Therefore, Tokyo has stepped up its economic support of Africa, mainly in the form of development assistance. As Bolade Eyinla pointed out, during the 1990s, Japan was the only one of the major OECD countries that was ready to increase its level of aid. The author's explanation of this exception from the general pattern of the 1990s with constant aid reductions is simply that Tokyo wanted to play a more prominent role in the international community, with the explicit aim of attaining a seat on the UN Security Council. Increasing its the aid commitment was considered one of the core instruments in pursuing this goal.

Turning to the fourth biggest donor of development assistance to Africa, Ulf Engel argues that there is a striking lack of substantial German interests in the continent. The limited interests are the main reason for the increasing marginalization of sub-Saharan Africa in Germany's international relations, he pointed out. On the other hand, it is not to be neglected that Africa has not disappeared totally from the German foreign policy agenda, which shows 


\section{Ulf Engel and Gorm Rye Olsen}

itself in the continued flow of development assistance. A combination of institutionalized bureaucratic interests and an ethically driven solidarity with the poor countries explains why Africa has remained on the German foreign policy agenda in the post Cold War period. It was emphasized that, among other factors, effective lobbying by the NGOs and renewed Africa interest among the political parties after the change of government in 1998 has helped to keep the continent on the agenda of German public debate. At the same time, agenda-setting of policy on Africa is increasingly taking place in Brussels, not in Berlin.

Thus, some of the most important OECD member states have a definite policy towards sub-Saharan Africa in spite of the fact that only very few of them have strong or substantial 'hard' interests in the region. The same duality can be identified with one of the two non-state actors analysed in this book, namely the European Union. Gorm Rye Olsen showed that from the very start in 1958, Africa was the main area of concern for the European Community's very limited common external policies. In line with the decolonization process, development cooperation with Africa became a core instrument in the EC's 'foreign policy'. Over the years, Africa has been able to keep a fairly central position on the foreign policy agenda of the EU, which is explained by the existence of strong 'European interests' in promoting the claims of the EU to become a significant international actor. Such general interests have been strongly buttressed by bureaucratic interests of the European Commission in having close collaboration arrangements with Africa.

It is a different story with the United Nations and its relationship to Africa. Around 1960 Africa had a fairly high priority on the UN agenda, reflecting an institutional interest in 'doing something' for the poor continent. The situation at the beginning of the current century is different from what it was 40 years before. Currently, the world organization lacks resources, both financial and human, which is a reflection of the power relations within the organization itself. The dominant powers, in particular the US, are not interested in having a strong independent world organization and therefore, since the 1970s, they have been reluctant to finance UN activities. Nevertheless, the UN pursues policies towards Africa. As Gorm Rye Olsen argued, the existence of UN policies towards and its engagement in Africa can on the other hand, be interpreted as an expression of the lack of interest among the great powers in Africa, as shown in their letting the UN take care of peacekeeping operations that no other major actors are willing to get involved in. This interpretation is buttressed by the fact that small and middle-sized OECD countries now contribute the bulk of financial support to the UN.

All important international actors analysed here have an interest in Africa, though it varies from one actor to the other and also over time. In accord with the reasoning of realism, the Western countries of the North have interests in Africa and therefore, have a more or less coherent policy towards the continent. However looking more closely into the analyses of the individual 
OECD member states, it appears that there are marked differences among the cases as far as the domestic interests and the type of domestic actors involved in decision-making are concerned.

Taking the type of interests first, only France and to an increasing extent the US have or have had economic interests in Africa. In comparison, German economic interests decreased remarkably sharply over the years. Until recently, France has had substantial economic interests in a number of African countries such as Côte d'Ivoire, and the existence of such interests can explain the close relationship between Paris and a considerable number of African countries. The situation is different as far as the US is concerned. It is only in fairly recent years that Washington has developed substantial economic interests in the region and this new situation is closely related to the changing international situation. Not least, it is tied to the US's strategic evaluation of the Middle East, and of Saudi Arabia in particular, as being increasingly unstable and vulnerable to terrorist attacks. For this political and strategic reason, Washington has been forced to look for alternative suppliers of crude oil. The official forecasts predict a significant increase in US oil imports from Africa and, for this rather simple reason, Africa is important to the US in a way and for reasons that have never been seen before.

Focusing on the political interests of leading OECD member states in sub-Saharan Africa, the analyses presented here reveal interesting patterns. Establishing and/or maintaining friendly relations with as many African governments as possible seems to have been a crucial determinant of both French, post-Cold War German and Japanese Africa policy. For these three countries, the prestige and the potential influence that come from having a permanent seat on the UN Security Council have been extremely important to top decision-makers when formulating the Africa policy. Put differently, because of the high priority given to a permanent seat on the Security Council, Africa became important both to France, Germany and to Japan. However, the continent is less important for its own sake or because of the great problems that confront the people living there. It is worth noting that the same kind of logic, external to Africa to a large extent, can explain the EU's policy towards the continent. In his analysis, Gorm Rye Olsen argued that the ambition of the EU to become a significant international actor can explain the Africa policy of the EU. This means that it is not primarily concern about the fate of Africa that explains the different policy initiatives of the EU but rather, as in the cases of France, Germany and Japan, it is international ambitions that to a large extent, but far from exclusively, explain the Africa policy.

Finally, it is possible to identify OECD member states where neither economic interests nor international political ambitions seem to be decisive for their Africa policy. At certain points in time Germany can be mentioned as an example where it is possible to argue that moral and ethical concerns explained considerable elements of its Africa policy, including the comparatively massive considerable aid budget. Maybe, Britain belongs in this 
category too. At least, as Gordon Cumming pointed out, moral concern to help the poorest continent combined with a long-term interest in spreading British culture and values certainly plays a role in shaping British Africa policy. Apart from Britain, France is the notable OECD member state where a cultural mission - and a related role conception - has certainly driven large parts of its Africa policy.

Turning the focus now to the domestic actors involved in policy-making in the different OECD member states, there is no doubt that there are differences in this respect. But at the same time, there are certainly also significant and important similarities. In all cases, there is a very strong bureaucratic component involved. The conspicuous role of the foreign affairs-cumdevelopment assistance bureaucracies reflects the correspondingly small and seldom active involvement of the governments in policy-making on Africa. Having noted this important point of resemblance, there are definitely also differences between the cases discussed here. It is obvious that France is a remarkable case, not least due to the existence of the two decision-making systems operating side by side. On the one hand, there is the informal networks of friends, patrons and clients combined with officials, and on the other hand, the official decision-making system with the Presidency of the Republic, the ministries and public authorities. This dual decision-making system, which closely resembles an African neo-patrimonial set-up, is not found anywhere else among the cases discussed here.

For obvious reasons, hardly any other domestic actors play an important role in formulating French Africa policy. This is striking as far as the NGOs are concerned. Compared to the situation in other OECD member states, France is an exception when compared to the influence NGOs have on the Africa policy of Germany and Britain in particular. In the US and in Japan, NGOs do not play an important role in policy-making. In the EU, they play a role in relation to development aid and humanitarian assistance to Africa. But in contrast to Germany or Britain, in the case of the EU these are predominantly international NGOs.

From the empirical analyses, it appears that the Africa policy of the different OECD member states reflect quite different configurations of interests, power and foreign policy cultures, and that these different configurations can explain differences between the policies. Nevertheless, there are significant similarities among the policies of the countries analysed here. The most striking point of resemblance is the constant reductions in net ODA disbursements to Africa, which became very obvious from 1992 and onwards. As already mentioned, all chapters emphasize within the larger foreign policy arena of the countries analysed here, Africa is of minor importance. Finally, for all OECD countries, September 11, 2001 meant that Africa became a region that attracted increasing attention for reasons of security and political stability. Thus in many cases, the Africa policy became 'infected' by policy rationales that have not usually been part of outside the concerns of 'traditional' Africa policy-makers. 
It is no doubt a challenge to reflect upon how we can explain the strong points of resemblance among the policies of the OECD member states in spite of considerable differences as far as domestic power relations are concerned. One starting point for the search for an explanation is that policies in Western societies tend to be developed within rather narrow policy sectors characterized by the involvement of a limited number of actors, such as a few politicians, civil servants, interest organizations, lobby groups, NGOs, and sometimes also researchers and journalists who take a special interest in a particular policy field (Smith 1993; Rhodes and March 1992).

Following the argument that policies tend to be developed within sectors, it is possible to propose the hypothesis that the Africa policies of the states of the North are devised within a narrow sector in each country. In some cases, it is the Ministry of Foreign Affairs that has the upper hand in decisionmaking within government; in other cases policy-making takes place with the participation of a limited number of civil servants from the Ministry of Foreign Affairs and from a Development ministry. In a number of OECD member states, NGOs and different lobby and interest groups participate and contribute inputs to the policy processes on Africa. With the increasing transnationalization and globalization of politics, politicians, civil servants, NGOs, etc. increasingly participate in international conferences, seminars and meetings on African issues, development topics, more narrow development assistance questions, security and stability, governance, democracy and human rights, etc. Concretely, the World Bank, the IMF, the OECD, the EU, and not least the UN and its different sub-organizations act as 'think tanks' on these issues. They constantly produce reports, analyses, background papers, and recommendations on a wide range of sub-themes of relevance for Africa. Not only do official OECD member states' representatives participate in meetings and seminars arranged by these bureaucratic think tanks, but also a number of respected individuals - for example politicians, civil servants, experts, researchers, etc. - give speeches or participate in working groups that produce reports and policy papers.

There is no doubt that such mutual exchanges of information and communicative interactions in international forums produce numerous feed-back loops. We hypothesize that significant policy changes in the OECD world are mediated through this type of international learning processes. Communication about specific development issues related to Africa and the construction of specific development discourses (cf. Abrahamson 2000) is a main source of Africa policies. Finally, one could also assume that among OECD member states a certain policy harmonization process is taking place, not least within the area of development and security issues. In summary, a kind of international 'policy community' has developed within a number of more or less narrow sectors. Consequently, a high degree of unanimity on the appropriate solutions to problems on which there is general agreement has emerged.

Based on the above line of reasoning, it is possible to explain that there is and has been a number of points of resemblance in the Africa policies of the 
OECD member states analysed in this book. Applied to the post Cold War years only, this particular period was characterized by the development of a general understanding among the participants who engaged in exchange and decision-making on sub-Saharan Africa that aid was not necessarily the solution to the problems of the continent. Moreover, an increasing consensus developed that Africa was a lost cause in development terms, and therefore it was possible to reduce the aid transfers to the continent (Easterley 2002; Riddell 1999; van de Walle 1999). The exception from the general pattern of aid reduction is Japan, which increased its aid to the continent, but this had very little to do with the situation on the continent. Moreover, with the September 11 attacks on the US, an international consensus has developed that the 'Global War on Terror' is a core goal for the OECD member states. The conception trickled down to the policy sector dealing with Africa, which quite quickly produced a new understanding of Africa's position within the new post September 11 international security framework. Thus, security rationales slowly infiltrated the realm of traditional Africa policies.

If the arguments presented above are valid, it is possible that the same mode of explanation can be applied to other countries that maintain an Africa policy. It may also apply to the cases of China, Russia, India, or South Africa, and possibly also Libya. There is hardly any doubt that these countries are influenced by the debates that takes place among the OECD member states on Africa. But the countries mentioned above do not participate to the same extent in the international policy community on Africa, and moreover they are influenced by quite different domestic concerns and domestic actors. To take South Africa as an example, Africa north of the Limpopo is extremely important to Pretoria, both for security and for economic reasons involving trade and South African FDIs in Africa. Moreover, the very different role conceptions of the post-apartheid regime have also contributed to place Africa high on the foreign policy agenda of South Africa. If the latter statement is correct, we have to conclude that there are fundamental differences in substance between, on the one hand, the motives of Africa policy among OECD member states, their determinants and the actors involved on their side, etc., and on the other hand, the Africa policies of nonOECD countries.

Returning to the introductory chapter in this volume and the general argument that Africa has been caught in the duality between marginalization and globalization, the analyses of the Africa policy of the different actors seem to confirm that the duality catches a crucial point about Africa in global politics. The post September 11 situation stresses that Africa definitely participates in the ongoing globalization processes, which may also include crime as well as terrorism. While the 'Global War on Terror' has placed Africa on the foreign policy agenda of many important international actors, it is obvious there is a limit to the willingness of these actors to invest resources in Africa, human as well as financial. 
Where does this statement leave us and the ambition to locate Africa on the agenda of the theoretical debates within international relations? We propose that Africa's place in global politics can be understood as part of a complex system that is defined by the interaction between different sub-systems of statehood. One component consists of the OECD member states that not only participate in, but constitute an international system that is still conceptualized as a Westphalian system of states or even 'nation states'. In principle, the OECD states exist and act within a form of regulated anarchy. The other component comprises a different sub-system made up of most of sub-Saharan Africa, and it can be described as a pre-Westphalian system. In many ways, the ideas of such interrelated sub-systems is close to the reflections of Georg Sørensen, who argues that the current international system contains no less than three main types of states, the 'modern', the 'post-colonial' and the 'post-modern' state (Sørensen 2001).

Applying the distinction to Africa in global politics, the international system can be described as the interface between 'post-colonial states' (Africa) on the one hand and 'post-modern' and 'modern states' (the OECD member states and the EU) on the other. From a realist IR perspective, what ties these different types of state together in one system are their security dilemmas. Specifically, the argument would be that the 'failed' post-colonial states in Africa represent a threat to the OECD states, i.e. a special security dilemma. Because of the high risk of domestic turmoil and violent conflicts within African states, Africa may represent a threat not only to post-modern states such as the EU, but also to modern states like the OECD member states (Sørensen 2001). Likewise, from a post-modern perspective, the representation of 'failed states' would constitute a serious challenge to the imagined Westphalian order, which needs to be 'corrected' to allow for system stability, most likely by reconstructing statehood or by reconstituting a sufficient degree of stateness in Africa's 'failed states'.

Sørensen maintains that 'the coexistence of qualitatively different types of states in the system is a challenge to IR theory' (Sørensen 2001: 164). One of his main avenues forward is to acknowledge that there is an intimate relationship between the 'domestic' and the 'international' and that therefore one should avoid analyses of purely domestic and purely international issues (Sørensen 2001: $186 \mathrm{ff}$ ). This it is exactly what the empirical analyses in this book have tried to do via the core problems the authors were asked to address. All chapters show that there is an intimate relationship between the domestic and the international issues when it comes to the foreign policies towards Africa.

France is an excellent example of this. The French Africa policy so clearly reflects domestic values and ideas, such as its civilizing mission in Africa. The same is the case for Germany, where ethics are from time to time allowed to play a crucial role, and also Japan, where domestic economic needs are important determinants of the country's Africa policy. In addition, it can be concluded that for the EU, it is the connection between internal bureaucratic 
interests and external political ambitions that determine the policy towards Africa. Maybe in the cases of the UK and the US, the relationship between domestic and external aspects is not so obvious, in relation to Africa as long as the discussion is restricted to the pre-September 11 situation. However, after the attacks on New York and Washington a relationship has clearly been established between internal security concerns and external policies towards Africa.

In conclusion, if Africa is to be integrated into the general reflections in the field of international relations reasoning, we suggest that one way forward is to go beyond the division between the 'international' and the 'domestic', and the traditional theoretical divide between 'international relations' and 'comparative politics'. One possible tool to bridge the gap empirically is to develop and apply the concept of an 'international policy community' and thereby accept that policy-making on Africa is integrated into the political system of the OECD member states, in spite of the fact that policy-making on specific issues in general takes place within a narrow policy segment or policy sector. By integrating the two aspects, the international and the domestic, it becomes obvious that Africa has a place not only in the actual policies of important international actors. Africa also has its place within the theoretical discussions of international relations.

Stated differently, by taking domestic circumstances, actors and interests in the OECD member states into consideration, we can understand the position and the role Africa plays in the wider world. It may be marginal in certain respects and at certain times in history, but at other times it may play a centrally important role. By applying the concept of an international policy community to policy-making on Africa, we also have a tool for understanding crucial aspects of the Africa policy of the OECD member states. The concept can also be used to explain why the continent retains a role out of any proportion to its economic weight, to quote Christopher Clapham (see Chapter 2 of this book). It is simply because the participants in the policy community on Africa agree that a number of threats, such as poverty, disease, crime, terrorism, state collapse, and state failure, are identified as threats to the security of OECD member states.

This, finally, poses an enormous theoretical challenge: to translate empirical observations into new theory building. Regardless of which of the major schools of thought in international relations one adheres to - the various forms of structuralism and post-structuralism - there is an increasing need to escape the 'territorial trap' (Agnew 1994; Brenner 1999; Barnett 2001) of international relations which is based on the exclusive conceptualization of the units of analysis as 'states'. Rather international relations and African studies will have to conceptualize the specific form of limited statehood found in many places in Africa, and to theorize about the place of the multitude of translocal and transboundary formations in Africa vis-à-vis the global order and global politics (Latham 2001; Mbembe 2002). Not only is the international system made up of different forms of statehood beyond the 
Westphalian order, which in themselves may constitute specific sub-systems, but the interaction between and across these formations definitely goes beyond a simple 'domestic' vs. 'external' divide. To follow the line of argument further, but seeing it from the opposite end: for the OECD member states and the international organizations to pursue 'effective' policies towards Africa, it is necessary to take into account that the division between domestic and international in the African pre-Westphalian system makes even less sense than in the Westphalian and post-Westphalian systems. Parts of Africa may not only be indicative of the future of the international system, they will also inform the way international relations as a sub-discipline of political science has to be advanced.

\section{References}

Abrahamsen, R. (2000) Disciplining Democracy: Development Discourse and Good Governance in Africa, London, New York: Zed Books.

Agnew, J. (1994) 'The Territorial Trap: The Geographical Assumptions of Internal Relations Theory', Review of International Political Economy, 1 (1), 53-80.

Barnett, M. (2001) 'Authority, Intervention and the Outer Limits of International Relations Theory', in T. Callaghy et al. (eds), Intervention and Transnationalism in Africa. Global-Local Networks of Power, Cambridge: Cambridge University Press, 47-65.

Brenner, N. (1999) 'Beyond State-centrism? Space, Territoriality and Geographical Scale in Globalization Studies', Theory and Society, 28, 39-78.

Easterly, W. (2002) The Cartel of Good Intentions: The Problem of Bureaucracy in Foreign Aid, Washington, DC: Center for Global Development, Institute for International Economics.

Latham, R. (2001) 'Identifying the Contours of Transboundary Political Life', in T. Callaghy et al. (eds), Intervention and Transnationalism in Africa. Global-Local Network of Power, Cambridge: Cambridge University Press, 69-92.

Mbembe, A. (2002) 'At the Edge of the World: Boundaries, Territoriality, and Sovereignty in Africa', in M. R. Beirringer and C. Young (eds), Beyond State Crisis? Postcolonial Africa and Post-Soviet Eurasia in Comparative Perspective, Washington, DC: Woodrow Wilson Center Press, 53-79.

Rhodes, R. A. W. and Marsh, D. (1992) 'New Directions in the Study of Policy Networks', European Journal of Political Research, 21 (1-2), 191-205.

Riddell, R. (1999) 'The End of Foreign Aid to Africa? Concerns About Donor Policies', African Affairs, 98 (392), 309-35.

Smith, M. J. (1993) Pressure Power and Policy. State Autonomy and Policy Networks in Britain and the United States, Hemel Hempstead: Harvester-Wheatsheaf.

Sørensen, G. (2001) Changes in Statehood. The Transformation of International Relations, Basingstoke: Palgrave.

van de Walle, N. (1999) 'Aid's Crisis of Legitimacy: Current Proposals and Future Prospects', African Affairs, 98 (392), 337-52. 


\section{Index}

Abacha, S. 62, 66

ACP 128-34; see also EU

ACRI 67

Adenauer, K. 109, 113

Afewerki, I. 31

African statehood 3, 5, 9-14, 49, 119, 169

African states 3, 8, 16, 20, 26-36

African Union 32, 101; see also OAU

AGOA 78, 86

Aiichiro, F. 104

Ajello, A. 135-6, 138

al-Qaeda 31

Amin, I. 24, 31, 57

Angola 4, 23-4, 26-7, 33-4, 36, 44-5, 51, 67, 75-6, 79, 136, 142, 147, 150

Annan, K. 142, 150

Balladur, E. 40, 43, 47

Banda, H. K. 36

Barre, S. 27, 29

Bédié, K. 51

Belgium 109, 149

Benin 30, 50, 99

Biafra 23, 25-6, 33, 44

Bin Laden, O. 8

Blair, T. 55, 59, 61, 63-6, 68, 70

Bøås, M. 143

Bokassa, J.-B. 24-5, 31, 50

Bongo, O. 47

Boutros-Ghali, B. 148

Brandt, W. 110

Bretton Woods 4, 47, 104

Brown, G. 61
Bull, H.11, 13

Burundi 78, 84, 101

Bush, G. W. (Jr) 85-6, 88, 89

Bush, G. W. (Sr) 77-9, 83

Buzan, B. 5

Cameroon 45, 51, 99, 117

Carstens, K. 114

Carter, J. 76

Central African Republic 24, 31, 44-5, 50-1

CFA Franc 43, 47

Chabal, P. 118

Chad 45, 51, 79

Chalker, L. 61

Cheney, D. 79

China, Peoples Republic of 3, 145, 168

Chirac, J. 40, 43, 48, 50-1

Christianity $35-6$

Clapham, C. 5, 9, 12

Clark, J. 13

Clinton, B. 77, 79, 82, 84, 86, 149

CNN 9

Cohen, H. 80

Commonwealth 56-7

Comoros 50

conditionality 7, 26-9, 33, 47, 49-51, $65-6,68,85-6,111,130$

conflict, violent $10-12,23-6,34-5,66-8$, $84,146-52$

Congo see DRC

Congo-Brazzaville 45, 51

Cook, R. 60

The editors wish to acknowledge the kind assistance of Stefanie Müller, Institute of African Studies, University of Leipzig, on the index. 
Côte d'Ivoire 39, 42, 44, 46-7, 51-2, 84, 94, 96, 165

Cotonou agreement 15, 49, 133-4; see also Yaoundé and Lomé agreements as well as EU

Crawford, G. 132

Cuba 5, 24, 76-7, 147

Daloz, J. P. 118

debt 48, 69, 103, 120

de-colonization 3, 9, 10, 21, 52, 75, 118

de Deus Pinheiro, J. 135

de Gaulle, C. 38, 40-1

Diouf, A. 51

Djibouti 31, 84

dos Santos, J. E. 51

DRC 15, 21-2, 24, 26, 29, 58, 66-8, 75, 78, 84, 94-5, 136, 138, 142, 147, 156; see also Zaïre

Dumont, R. 49

Dunn, K. 12

Dupuch, M. 51

East Africa 35, 58

East Germany 109, 100, 111, 119

EC 110-11; see also EU

Egypt 27

Elf-Aquitaine 40-1, 43, 51

Emizet, K. 157

Equatorial Guinea 24, 50, 79

Eritrea 22, 24, 31, 34, 36, 88, 101, 136, 142, 151-2, 159

Ethiopia 5, 22, 24, 26-7, 31, 34, 83, 94, 99, 101, 109, 114, 119, 136, 142, 147, 151-2, 159

EU 12, 15, 28, 48-9, 53, 57-8, 66, 111, 113, 115, 121, 125-39, 164-7, 169;

Common Foreign and Security Policy 128, 134-6, 138; development assistance 137-8; interests 126-8, 132-4; policy changes $128-34$; security policy 134-8; prior to 1993 see also EC; see also Yaoundé, Lomé and Cotonou agreements

Eyadéma, G. 51

Fischer, J. 111

Foccart, J. 40-3, 50

France 3, 14, 21, 23-5, 28, 31, 38-53, 56-7, 102, 109, 111, 115-16, 121, 131-2, 145, 153, 162, 165-6, 169; decision-making 40-5; development assistance 46, 48; Françafrique 39, 40,
$42-4,48,2$; instruments $44-52$; interest 39-40, 46-53; mission civilatrice $39,49,53$; policy changes 43-4; policy culture 38-40; security policy 44-6

G-7 see G-8

G-8 8, 57-8, 88, 98, 99, 103

Gabon 40, 44-5, 47, 51, 96

Gambia 99

GATT 92, 94-5

Genscher, H.-D. 111, 114

Germany 14-15, 108-22, 131, 163, 165-6, 169; decision-making 112-18; development assistance 119-21, 129-34; FDI 121; instruments 119-22; interests 109-12; policy changes 109-12; policy culture 109-12; security policy 121-2; trade 121 ; see also East Germany

Ghana 21-2, 29, 56, 65, 94, 96, 99, 104, 119

Gilpin, R. G. 4

Giscard d'Estaing, V. 38, 45, 50

Global War on Terrorism 8, 31, 58, 78, 137, 168

Gorbatchev, M. 77

Great Lakes 31, 68, 135, 138, 147

Guinea 21-2, 75, 94, 119

Guinea Bissau 4

Haile-Selassie, I. 22

Hammarskjold, D. 145

Hempstone, S. 28

Hill, C. 134

HIV/Aids 35-6, 78, 84, 88-9, 118

Holland, M. 135

Horn of Africa 4, 8, 22, 24, 34, 57, 75, 151

Houphouët-Boigny, F. 39, 43, 45, 47

Hurd, D. 60

IFIs $12,26,96,97,111,113$

Ikenberry, J. G. 85

IMF 12, 15, 43, 167

INGOs 12, 30, 34-5, 62, 64, 112, 117 ; see also NGOs

international system 4-6, 13-16, 20, 33-6, 169; see also Westphalian system

IR theory 1-16, 108, 165-71; see also African statehood, international system, Westphalian system

Islam 35-6 


\section{Index}

Japan 14-15, 92-105, 153, 163, 165-6, 168-9; decision-making 100; development assistance 95, 97, 99, 102-3; FDI 95; instruments 93-100; interests 92-104; policy culture 100-1; trade 94

Jospin, L. 40, 44, 51

Juppé, A. 43, 131

Kabbah, A. 62

Kabila, L. 142

Kansteiner, W. 79

Kennedy, J. F. 75

Kenya 28, 31, 57, 59-60, 66, 94, 96, 99, 104, 117, 152

Kerekou, M. 50

Kieh, G. 75

Kimura, T. 95

Kinkel, K. 114

Kissinger, H. 76

Klingval, M.-I. 137

Kohl, H. 111, 113

Kono, F. 94

Lagos Plan of Action 32

Lake, A. 86

Liberia 29, 34, 75, 78, 80, 84-5, 94, 109 , $151-2$

Libya 45, 66, 168

Lissouba, P. 51

Lister, M. 134

Lomé agreement 12, 15, 28, 121, 126, 128-34; see also Yaoundé and Cotonou agreements as well as EU

McNeill, D. 143

Madagascar 51, 87

Major, J. 55, 61, 64-7, 69, 70

Malawi 36, 96, 117

Mali 75, 86

Mandela, N. 30

Matsuura, K. 104

Mazrui, A. 22

Mbeki, T. 32

Mengistu, H. M. 24

Middle East 24, 165

Millennium Development Goals 69

Mitterrand, F. 28, 38, 40, 43, 50

Mobutu, S. S. 43

Morgenthau, H. 1, 4

Mori, Y. 99

Mozambique 4, 34, 80,101
Mugabe, R. 32, 57, 61, 66, 70, 85

Muldoon, J. 153

Museveni, Y. 29, 66

Namibia 34, 68, 75, 95, 110, 116, 118 , $122,147-8,153$

NATO 122

neo-patrimonialism 10, 49, 119

NePAD 8, 32, 58, 104, 111, 118

NGOs 12, 35, 67, 68 see also INGOs

Nguema, M. 24, 25, 50

Nguesso, D. S. 51

Nielson, P. 137

Niger 40, 45, 95

Nigeria 12, 14, 23, 25, 29, 35-6, 45, 60, $62,66-7,79,86,94-6,99,104,114$, 117,121

Nixon, R. M. 76

Nkrumah, K. 21

Non-Aligned Movement 4

Nyerere, J. K. 96

Obuchi, K. 102

Oda, S. 97, 104

OECD 7, 8, 13-14, 92, 113

Ogata, S. 104

oil 79; oil crisis of October 1973 94; oil-price shock 4

OAU 22-3, 31-3, 95, 101; OAU

Mechanism for Conflict Prevention, Management and Resolution 32, 101; see also African Union

Ottaway, M. 86

Oxfam 34, 62

pan-Africanism 4

Pasqua, C. 44

Pompidou, G. 38, 40

Portugal 4, 21, 23, 76, 105, 108

Powell, C. 88

Queen Elizabeth II 68

Ratsiraka, D. 51

Rawlings, J. 66

Reagan, R. 77, 96, 153

RECAMP 45-6

Rhodesia 56-7

Russia 145, 168; see also Soviet Union

Rwanda 9, 15, 29, 32, 34, 36, 38, 42-3, $45,58,67,78,80,101,135,149,150$, 152,156 
Sadat, A. 27

Sankoh, F. 142

São Tomé and Príncipe 79

Saro-Wiwa, K. 62

Saudi Arabia 35, 165

Save the Children 34

Schmidt, H. 110, 112

Schraeder, P. 82

Senegal 44-5, 51, 94, 96

September 11, 2001 2, 8-9, 15-16, 31, $35,55,57-60,70,99,111,126,134$, $137-8,162,166,168$

Shell 62

Short, C. 61, 63, 70

Sierra Leone 14, 29, 30, 35, 60, 62, 66-8, $78,84-5,94,101,136,142,150-1$

Somalia 9, 15, 22, 24, 27-9, 31, 60, 67, $75,77,82-3,99,122,147-50,152,159$

Sonoda, S. 96

South Africa 14, 28, 30, 32, 34, 36, 56-7, $59,60,70,75-6,83,86-7,93,95,99$, 104-5, 109, 111, 114, 118-19, 121, $135,156,168$

Southern Rhodesia 76, 153; see also Zimbabwe

Soviet Union 3, 5, 15, 21, 24-8, 76-7; see also Russia

Sørensen, G. 134, 169

Steven, S. 30

Strauß, F.-J. 111

structural adjustment programme 26, 96, 98; see also IMF and World Bank

Sudan 24, 26-7, 34, 68, 75, 78, 83, 85, $99,110,119,142$

Sullivan, A. 150

Suzuki, Z. 96

Swaziland 87-8

Tanaka, K. 95

Tanzania 24, 29, 31, 45, 57, 61, 68, 94, 96, 99, 104, 109

Thatcher, M. 56-7, 153

Togo 51, 117

Tombalbaye, F. 45

trade, illegal 11, 36
Uganda 24, 29-30, 31, 35, 43, 57, 66-8, 88,94

UK 14, 21, 55-77, 96, 109, 111, 131, 141, 150-1, 162, 165-6, 169; colonial policy 55-6; decision-making 56, 60-4; development assistance 56, 68-70; FDI 60; instruments 64; interests 55-60, 64-70; policy changes 59-60; policy culture 55-9, 60, 64; security policy $57,66-8$

UNDP $154-5$

UN 3, 9, 15, 21-2, 33, 85, 88, 93, 95, 97 , $101,103,121,142,164-5,167$; decision-making 145-6; development assistance 152 ; security policy $146-52$

UNHCR 154-5, 157-8

USA 3, 7-9, 15, 21, 24, 26, 29-30, 36, 47, 52, 67, 74-90, 92, 96, 98, 102, 104-5, 115-16, 137, 145, 147-50, 153, 158-9, 162-3, 165-6, 169; decisionmaking 80-3; instruments 78-9, 83-9; interests 74-9; 83-90; policy changes 75-9; policy culture 75-9; security policy $84-5$; trade 87

von Weizsäcker, R. 113

Waltz, K. 1, 4

Westphalian system 10, 13, 15, 169; see also international system

Wieczorek-Zeul, H. 120

World Bank 12, 15, 26-7, 43, 49, 57, 96, $111,121,153,155,167$

WTO 12, 69-70, 133

Yaoundé agreement 15, 121, 128 see also Lomé and Cotonou agreements as well as EU

Zaïre 43, 45, 94-6, 117, 156; see also DRC

Zambia 30, 76, 94, 96, 99

Zimbabwe 32, 34, 36, 55, 57, 61, 66, 68, 85, 99, 117; see also Southern Rhodesia 
